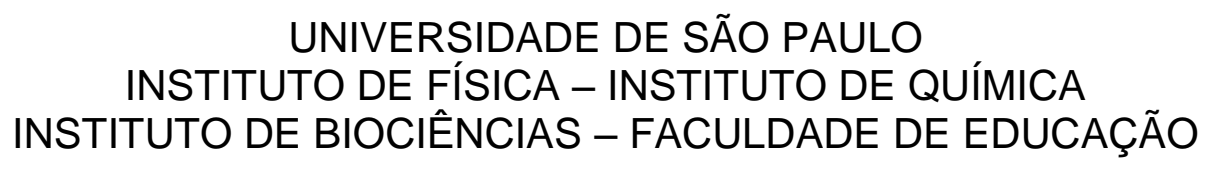

MÁRLON CAETANO RAMOS PESSANHA

Estrutura da Matéria na Educação Secundária: Obstáculos de Aprendizagem e o Uso de Simulações Computacionais 


\section{MÁRLON CAETANO RAMOS PESSANHA}

\section{Estrutura da Matéria na Educação Secundária: Obstáculos de Aprendizagem e o Uso de Simulações Computacionais}

Tese apresentada ao Instituto de Física, ao Instituto de Química, ao Instituto de Biociências e à Faculdade de Educação da Universidade de São Paulo como requisito parcial para a obtenção do título de doutor em Ciências.

Orientador: Prof. Dr. Mauricio Pietrocola Pinto de Oliveira

Área de concentração: Ensino de Física 
Autorizo a reprodução e divulgação total ou parcial deste trabalho, por qualquer meio convencional ou eletrônico, para fins de estudo e pesquisa, desde que citada a fonte.

\author{
FICHA CATALOGRÁFICA \\ Preparada pelo Serviço de Biblioteca e Informação \\ do Instituto de Física da Universidade de São Paulo \\ Pessanha, Márlon Caetano Ramos \\ Estrutura da matéria na educação secundária: obstáculos \\ de aprendizagem e o uso de simulações computacionais - São \\ Paulo, 2013. \\ Tese (Doutorado) - Universidade de São Paulo. Faculdade \\ de Educação, Instituto de Física, Instituto de Química e Instituto \\ de Biociências. \\ Orientador: Prof. Dr. Mauricio Pietrocola Pinto de Oliveira \\ Área de Concentração: Física \\ Unitermos: 1.Aprendizagem; 2) Estrutura da Matéria (Física \\ Moderna); 3. Ensino Médio; 4.Tecnologia Educacional; 5) \\ Modelos. \\ USP/IF/SBI-115/2013
}


Nome: PESSANHA, Márlon Caetano Ramos

Título: Estrutura da Matéria na Educação Secundária: Obstáculos de Aprendizagem e o Uso de Simulações Computacionais

Tese apresentada ao Instituto de Física, ao Instituto de Química, ao Instituto de Biociências e à Faculdade de Educação da Universidade de São Paulo como requisito parcial para a obtenção do título de doutor em Ciências.

Orientador: Prof. Dr. Mauricio Pietrocola Pinto de Oliveira

Área de concentração: Ensino de Física

Aprovado em:

\section{Banca Examinadora}

Prof. Dr. Ivã Gurgel Instituição: IF-USP

Julgamento: Assinatura:

Prof. Dr. Marcelo Giordan Santos Instituição: FE-USP Julgamento: Assinatura:

Prof. Dr. Marcelo Alves Barros Instituição: IFSC-USP

Julgamento: Assinatura:

Prof. Dr. Maxwell Roger da Purificação Siqueira Instituição: UESC Julgamento: Assinatura:

Prof. Dr. Nelson Studart Filho Instituição: UFSCAR Julgamento: Assinatura: 
Dedico à minha esposa Sabrina, à minha mãe Romirte, ao meu pai Aloisio e ao meu irmão Maikon, que tanto me apoiaram em todo meu percurso acadêmico, da graduação ao doutorado. 


\section{AGRADECIMENTOS}

Terminando mais esta etapa acadêmica em minha vida, olhando para trás, vejo muitas pessoas que de alguma forma me apoiaram e contribuíram em minha caminhada. Seriam necessárias muitas páginas aqui para agradecer a cada um. Sendo assim, me restrinjo nestas linhas a agradecer àqueles que de uma forma mais direta contribuíram para este trabalho:

Ao meu orientador Maurício Pietrocola, pelos comentários e sugestões sempre precisos, que contribuíram de forma decisiva no planejamento e desenvolvimento da pesquisa.

Aos colegas do Núcleo de Pesquisa em Inovação Curricular (NUPIC) da Faculdade de Educação da Universidade de São Paulo, pelas discussões nas reuniões de grupo e pelas conversas informais que serviram para descontrair. Em especial, agradeço a Tadeu de Souza, Alexandre Campos, Maria Elena Truyol e Aline Sabino pelo importante auxílio nas últimas coletas de dados.

Aos membros do Centre de Recerca per a l'Educació Científica i Matemàtica (CRECIM) da Universitat Autònoma de Barcelona, que tão bem me acolheram durante o meu período de estágio de doutorado na Catalunha. Agradeço em especial às professoras Digna Couso e Roser Pintó, pela orientação, e a Luisa Herreras e Josep Olivella, pela importante colaboração no desenho e implementação do curso na Catalunha.

Aos professores Marcelo Giordan e Ivã Gurgel, pelas sugestões e comentários no exame de qualificação.

À FAPESP pela bolsa de doutorado, e à CAPES pela bolsa de doutorado sanduíche no exterior.

Muito obrigado a todos!

Moltes gràcies a tots!

¡Muchas Gracias a todos! 


\section{RESUMO}

PESSANHA, M. C. R. Estrutura da Matéria na Educação Secundária: Obstáculos de Aprendizagem e o Uso de Simulações Computacionais. 2014. 229 f. Tese (Doutorado) - Instituto de Física, Instituto de Química, Instituto de Biociociências, Faculdade de Educação, Universidade de São Paulo, São Paulo, 2014.

Os conceitos presentes na Física Moderna e Contemporânea (FMC), como aqueles relacionados à estrutura da matéria, rompem com ideias do cotidiano e envolvem fenômenos e entidades que são parte de uma realidade tecnicamente construída e não podem ser percebidos de forma direta pelos sentidos humanos. Seu ensino requer meios representativos, e as simulações computacionais atendem a esta necessidade. Nesta pesquisa, tendo como marco teórico ideias relacionadas ao estudo dos modelos mentais e conceituais, ideias provenientes da epistemologia da ciência de Bachelard, e considerando algumas ideias presentes na teoria das situações didáticas de Brousseau, buscamos identificar obstáculos de aprendizagem que atuam no ensino de conceitos do tópico Estrutura da Matéria em que são utilizadas simulações computacionais. Tendo como pano de fundo um processo iterativo de desenho, implementação e redesenho de um curso sobre a estrutura da matéria e aceleradores de partículas, analisamos a emersão de possíveis obstáculos epistemológicos, e verificamos como obstáculos didático-pedagógicos facilitavam esta emersão. Como resultados, identificamos obstáculos epistemológicos e didático-pedagógicos de diferentes naturezas, entre os quais, alguns relacionados à percepção ingênua de fenômenos do cotidiano, alguns relacionados ao uso de metáforas e imagens, e outros relacionados a um raciocínio limitado e incongruente. Acreditamos que as análises e conclusões desta pesquisa contribuem para uma reflexão sobre o ensino de tópicos de Física Moderna e Contemporânea, e sobre o uso de simulações computacionais como ferramentas pedagógicas.

Palavras-chave: Física Moderna e Contemporânea. Estrutura da Matéria. Obstáculos Epistemológicos. Obstáculos didático-pedagógicos. Simulações Computacionais. 


\section{ABSTRACT}

PESSANHA, M. C. R. Structure of Matter in Secondary Education: Learning Obstacles and the Use of Computer Simulations. 2014. 229 f. Tese (Doutorado) - Instituto de Física, Instituto de Química, Instituto de Biociociências, Faculdade de Educação, Universidade de São Paulo, São Paulo, 2014.

The concepts of Modern and Contemporary Physics (MCP), such as those related to the structure of matter, break with the everyday ideas and involve phenomena and entities that are part of a reality technically built that cannot be directly perceived by human senses. Its teaching requires representative media, and the computer simulations meet this need. In this research, having as theoretical framework ideas related to the study of mental and conceptual models, ideas from the epistemology of science of Bachelard, and considering some of the ideas present in the theory of didactic situations of Brousseau, we seek to identify learning obstacles who work in teaching concepts of the topic Structure of Matter in which computer simulations are used. Against the backdrop of an iterative process of design, implementing and redesign of a course on the structure of matter and particle accelerators, we analyze the possible emergence of epistemological obstacles, and check how didactic-pedagogical obstacles facilitated this emersion. As a result, we identified epistemological obstacles and didactic-pedagogical obstacles of different nature, including some related to the naive perception of everyday phenomena, some related to the use of metaphors and images, and other related to a limited reasoning and incongruous. We believe that the analysis and conclusions of this research contribute to a reflection on the teaching of Modern and Contemporary Physics topics, and on the use of computer simulations as educational tools.

Palavras-chave: Modern and Contemporary Physics. Structure of Matter. Epistemological Obstacles. Didactic-pedagogical Obstacles. Computer Simulations. 


\section{LISTA DE FIGURAS}

Figura 1. Representação do significado do termo analogia. Adaptado de Duit (1991).

Figura 2. Representação da interpretação de uma metáfora.......................................44

Figura 3. Representação do significado para os termos analogia e modelo.

Adaptado de Duit (1991).

Figura 4. Representação do processo de aprendizagem e as noções de modelo conceitual e modelos mentais. Adaptado de Clement (2000)......................................50 Figura 5. Representação do processo de ensino-aprendizagem elaborado a partir do esquema proposto por Clement (2000).

Figura 6. Representação do processo de ensino-aprendizagem mediado por analogias, baseando-se nos esquemas propostos por Duit (1991) e na versão já adaptada do esquema de Clement (2000).

Figura 7. Representação do processo de ensino-aprendizagem mediado por analogias e a atuação de obstáculos epistemológicos e didático-pedagógicos.

Figura 8. Representação do processo iterativo de desenho e implementação de sequências didáticas.

Figura 9. Processo de seleção e análise de dados.

Figura 10. Esquema representativo dos modelos conceituais parciais e final envolvidos no curso.

Figura 11. Tela capturada do ambiente virtual utilizado no contexto catalão............105

Figura 12. Tela capturada do ambiente virtual utilizado no contexto paulista...........105

Figura 13. Tela capturada da simulação Rutherford Scattering que representa o experimento de Geiger-Marsden.

Figura 14. Tela capturada da simulação Up Close Rutherford Scattering que representa o núcleo de um átomo segundo o modelo atômico de Rutherford

Figura 15. Tela capturada da simulação que representa o núcleo de um átomo segundo o modelo atômico de Rutherford.

Figura 16. Tela capturada da simulação Scattering and Structure que representa trajetórias para interações de natureza elétrica e mecânica.

Figura 17. Exemplos de imagens utilizadas no roteiro hipertextual. ..........................109

Figura 18. Imagem utilizada ao apresentar os experimentos executados no LHC. .110 Figura 19. Tela capturada da animação utilizada no curso, que representava o LHC em funcionamento.

Figura 20. Representação da trajetória da partícula alfa em seu deslocamento próximo ao núcleo atômico.

Figura 21. Desenho do aluno $\mathbf{A}_{13}\left(\mathbf{I}_{3}\right)$, que indica erroneamente os vetores da força elétrica atuante sobre a partícula alfa em seu deslocamento próximo ao núcleo atômico.

Figura 22. Imagem presente nas questões que envolviam uma predição da interação entre partículas alfa e o átomo de Thomson, utilizada nas implementações $\mathbf{I}_{\boldsymbol{0}}$ e $\mathbf{I}_{\mathbf{1}} .125$ Figura 23. Representação das trajetórias das partículas alfa lançadas em direção a um átomo de ouro, segundo o modelo atômico de Thomson.

Figura 24. Desenho feito pelo aluno $A_{-}\left(I_{5}\right)$ para representar a interação entre partículas alfa e um núcleo atômico.

Figura 25. Círculo presente na simulação Rutherford Scattering, que era interpretado como uma visualização direta do átomo de Thomson. 
Figura 26. Representação do átomo de Thomson

Figura 27. Desenho feito pelo aluno $\mathbf{A}_{\boldsymbol{X}}\left(\mathbf{I}_{4}\right)$ para representar o átomo nuclear e as trajetórias de partículas alfa que interagem com o átomo.

Figura 28. Desenho feito pela aluna $\boldsymbol{A}_{3}\left(I_{5}\right)$ para representar a interação entre as partículas alfa e o núcleo de um átomo.

Figura 29. Desenho feito pelo professor $\mathbf{P}_{4}$, ao explicar os desvios com ângulos pequenos no experimento de Geiger-Marsden considerando o modelo atômico com um núcleo

Figura 30. Representação do átomo de Thomson utilizada nas duas últimas implementações do curso na Catalunha.

Figura 31. Desenho de um dos alunos, com a representação da estrutura atômica indicando a concentração de massa no núcleo.

Figura 32. Desenho de um dos alunos, com a representação da estrutura atômica indicando a concentração de carga elétrica positiva no núcleo 


\section{LISTA DE QUADROS}

Quadro 1. Etapas do processo iterativo de desenho e implementação do curso.......93 Quadro 2. Estrutura geral do curso e tempo estimado para a realização de cada atividade. 101 Quadro 3. Comparação de aspectos da técnica envolvida no experimento analógico, no experimento de Geiger-Marsden e nos aceleradores de partículas.....................104 Quadro 4. Tipologia de obstáculos epistemológicos. ...............................................113 Quadro 5. Lista de situações com a identificação do tipo de obstáculo epistemológico atuante 


\section{LISTA DE SIGLAS}

CERN European Organization for Nuclear Research

CRECIM Centre de Recerca per a l'Educació Científica i Matemàtica

DBR Design-Based Research

FAPESP Fundação de Amparo à Pesquisa do Estado de São Paulo

FEUSP Faculdade de Educação da Universidade de São Paulo

FMC Física Moderna e Contemporânea

LHC Large Hadron Collider

NUPIC Núcleo de Pesquisa em Inovação Curricular

OCDE Organisation for Economic Co-operation and Development

REVIR Realitat-Virtualitat

SD Sequência Didática

TIC Tecnologias da Informação e da Comunicação

TLS Teaching-Learning Sequences

UAB Universitat Autònoma de Barcelona

USP Universidade de São Paulo 


\section{SUMÁRIO}

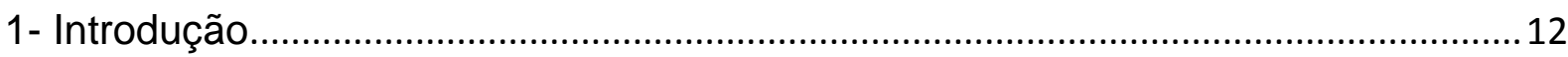

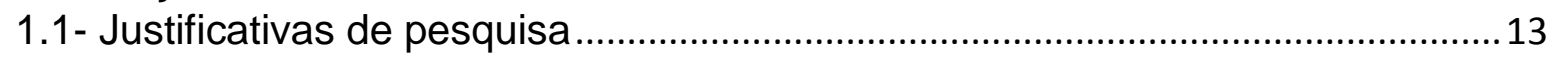

1.2- Objetivos e questões de pesquisa ...................................................................... 15

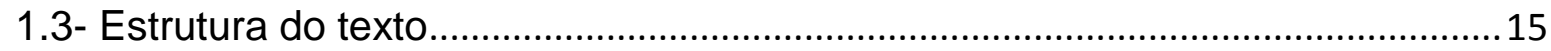

PARTE I - FÍSICA MODERNA E CONTEMPORÂNEA E O USO DE TIC ....................17

2- A Física Moderna e Contemporânea .......................................................................... 17

2.1- O rompimento com a Física Clássica e com o conhecimento comum: um

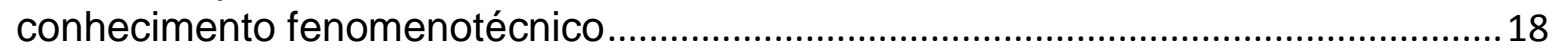

2.2- A Física Moderna e Contemporânea na Educação Secundária ...........................26

3- Tecnologias da Informação e Comunicação na educação ...........................................33

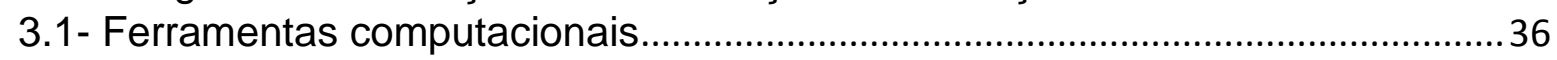

3.2- Uma visão crítica sobre o uso de TIC na educação ...............................................39

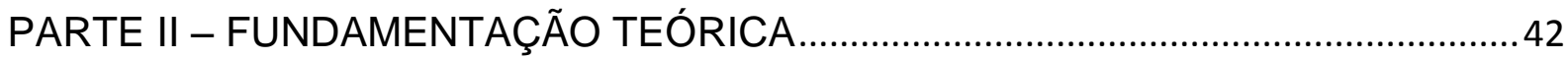

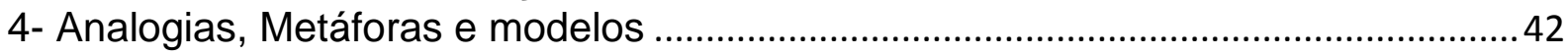

4.1- Diferenciação entre analogias e metáforas .........................................................42

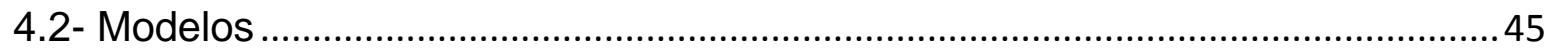

4.3- Abordagens sobre os modelos e analogias na literatura .....................................58

5- Obstáculos de aprendizagem: Brousseau e Bachelard...............................................61

5.1- Obstáculos epistemológicos na perspectiva de Bachelard...................................64

5.2- Obstáculos epistemológicos na educação …………………………………....... 71

6- Analogias, modelos e obstáculos no estudo sobre o ensino de FMC com o uso

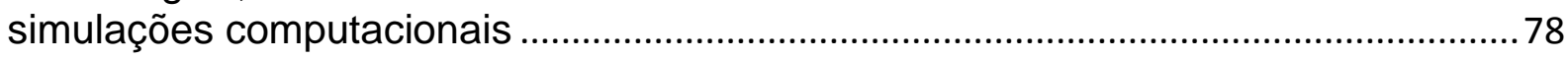

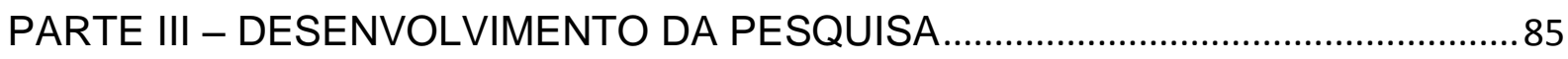

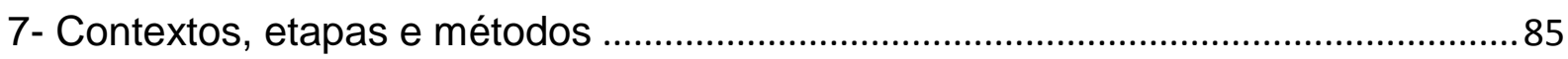

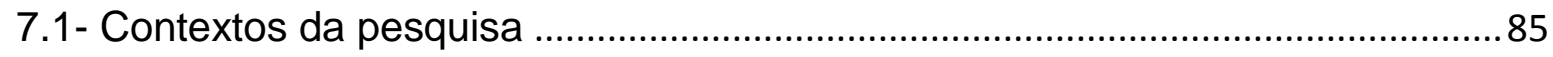

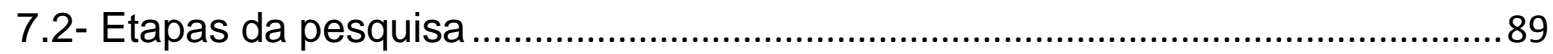

8- O curso sobre estrutura da matéria e aceleradores de partículas ..............................97

8.1- Desenho do curso: inspiração nos estudos sobre TLS .......................................97

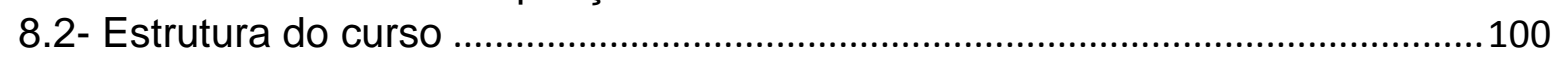

PARTE IV - RESULTADOS, ANÁLISES E CONSIDERAÇÕES.................................111

9- Resultados e análises ..........................................................................................111

9.1- Uma tipologia de obstáculos epistemológicos ……………………………......112

9.2- Obstáculos epistemológicos identificados .........................................................114

9.3- Obstáculos didático-pedagógicos associados …………………….................157

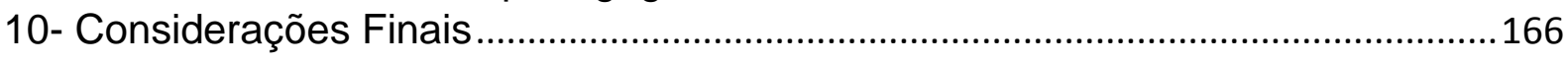

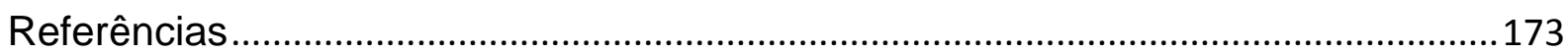

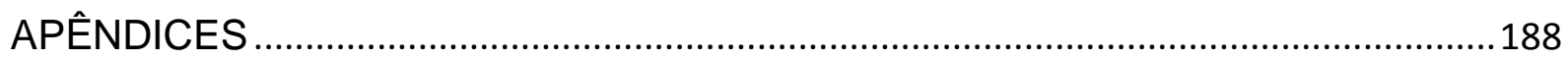




\section{1- INTRODUÇÃO}

A Física dedica-se ao estudo dos diversos fenômenos que povoam o mundo ao nosso redor, desde os movimentos facilmente perceptíveis no cotidiano, ao movimento orbital dos elétrons. Assim, as teorias físicas sustentam o entendimento humano sobre fenômenos e entidades que atuam do macrocosmo ao microcosmo. A tradição metódica e racional iniciada por Galileu, Newton e outros ilustres que em sua época eram conhecidos como filósofos naturais, permitiu o desenvolvimento de um conjunto de conceitos que servem como ferramentas intelectuais para lidar com os fenômenos. Os conceitos científicos ditos clássicos podem ser entendidos como uma sofisticação ou evolução conceitual de ideias presentes no conhecimento do senso comum. Os objetos presentes no mundo perceptível, suas interações e, de certa forma, o valor prático que elas possuem no cotidiano, ajudam a formar as ideias do senso comum. Por outro lado, os conceitos físicos presentes nas teorias modernas e contemporâneas não dispõem de referentes diretos no mundo cotidiano perceptível, e na maioria das vezes se vinculam a fenômenos que só podem ser reproduzidos com o uso de equipamentos sofisticados. Desta forma, os conceitos presentes na Física Moderna e Contemporânea (FMC) rompem com ideias do cotidiano, induzem a ideias contra intuitivas que vão além do entendimento que resulta da experiência cotidiana.

Apesar dessas ideias não pertencerem ao mundo do aluno de forma direta, diversas situações do cotidiano envolvem elementos que podem ser melhor interpretados se forem utilizadas as entidades e as fenomenologias envolvidas na Física Moderna e Contemporânea. Com base nisso e em outros elementos, tópicos de FMC têm sido inseridos em currículos da Educação Secundária. Um problema de fundo que surge neste contexto reside nos meios de tornar tais entidades e fenomenologias ligadas à FMC acessíveis aos alunos. As fenomenologias e entidades que atuam no microcosmo e no macrocosmo, por não poderem ser acessadas diretamente pelos sentidos humanos, necessitam de técnicas e equipamentos avançados, como aqueles utilizados pelos cientistas, ou de meios representativos para serem apresentados e estudados. No contexto da Educação Secundária, utilizar os mesmos sofisticados equipamentos dos cientistas é algo inviável por muitas razões, em especial, pelas limitações financeiras e pela 
sofisticação técnica envolvida. Assim, o uso de meios representativos se apresenta como, talvez, o único caminho possível. As Tecnologias da Informação e Comunicação (TIC), como é o caso das simulações computacionais e das imagens digitais, vão ao encontro desta necessidade de representação, se apresentando como ferramentas potenciais no estudo de tópicos de FMC.

O uso destes novos recursos não somente atende uma necessidade própria do conteúdo de FMC, como também atende a uma necessidade dos processos educacionais acompanharem e se integrarem a um panorama atual: os múltiplos novos recursos tecnológicos presentes na sociedade atual provocam mudanças econômicas, sociais, filosóficas, políticas e culturais; os processos educacionais, sendo algo que integram a sociedade, também necessitam se modificar e se adaptar a estes novos paradigmas tecnológicos.

Com o advento das TIC, defrontamo-nos com novas possibilidades e desafios nos processos de ensino-aprendizagem. Tais tecnologias já se encontram no cotidiano dos alunos e seu uso no ensino pode proporcionar uma motivação para a aprendizagem e, especificamente no uso de simulações, podem atuar como facilitadores na representação de conceitos, fenômenos e técnicas. Neste cenário, há de se questionar, no entanto, sobre as dificuldades que podem surgir no uso dessas novas tecnologias, e é neste sentido que apresentamos esta pesquisa.

\section{1- Justificativas de pesquisa}

A presente pesquisa envolve um estudo sobre a aprendizagem de conceitos presentes no tema Estrutura da Matéria, em situações de ensino com o uso de simulações computacionais. Para isso, voltamos nossa atenção para elementos inerentes ao processo de ensino-aprendizagem destes conceitos, em especial, aos obstáculos epistemológicos e didático-pedagógicos que se apresentam.

Considerando a gradual inserção da Física Moderna e Contemporânea no currículo da Educação Secundária, e considerando as particularidades desta temática e suas consequências ao ensino e aprendizagem, percebemos a necessidade de pesquisas que busquem testar e analisar propostas de ensino de tópicos de Física Moderna e Contemporânea. Trabalhos desse tipo já vêm sendo realizados há alguns anos pelo Núcleo de Pesquisa em Inovação Curricular (NUPIC) da Faculdade de Educação da Universidade de São Paulo, e resultados positivos 
têm sido obtidos. Entretanto, em relação à temática da Estrutura da Matéria, ainda percebemos uma carência de estudos mais sistemáticos. A presente pesquisa vai ao encontro desta necessidade.

Somando a isto, percebemos a necessidade de pesquisas que envolvam uma análise mais aprofundada sobre o uso de recursos computacionais, como é o caso das simulações computacionais. Desde antes da popularização dos microcomputadores no Brasil, que ocorreu principalmente a partir da segunda metade dos anos noventa do século $X X$, muitas pesquisas já vêm sendo realizadas sobre o uso da computação no ensino de Física (BEICHNER, 1990; SANTOS, 1990; WHITELOCK et al., 1993; ROTH, 1995; KLEER; THIELO; SANTOS, 1997; YAMAMOTO; BARBETA, 2001; BOECHAT, 2006; BETZ; LIMA; MUSSATO, 2009). No entanto, uma quantidade razoável das pesquisas que vêm sendo realizadas trata do desenvolvimento técnico de ferramentas computacionais destacando as potencialidades de uso na educação, ou trata de experiências de uso de tais ferramentas com um olhar mais superficial ou final sobre a aprendizagem. São necessárias pesquisas que visem analisar o processo de ensino-aprendizagem quando do uso destas ferramentas tecnológicas, que mais que uma descrição de processos e das tecnologias, busquem identificar elementos presentes neste uso que atuem como obstáculos à aprendizagem, assim como identificar os meios pelos quais tais obstáculos podem ser superados.

Pela natureza dos conceitos envolvidos na Física Moderna e Contemporânea, em que as entidades e fenômenos necessitam de um meio representativo para serem estudados, o ensino destes conceitos se apresenta como um contexto especialmente favorável para investigar o uso das simulações computacionais.

A pesquisa que aqui apresentamos pretendeu atender a essa dupla necessidade e, assim, buscamos analisar de forma aprofundada as situações de uso de simulações computacionais no ensino de conceitos envolvidos no tópico de Estrutura da Matéria. 


\section{2- Objetivos e questões de pesquisa}

Neste estudo classificamos as simulações computacionais como representações de um determinado objeto de estudo, em que seu uso se baseia em relações de analogias. Entendemos que as situações de uso destas representações são especialmente relevantes para definir o sucesso ou insucesso enquanto ferramentas educacionais. Entendemos que é neste uso que está presente a emersão e a superação de obstáculos relacionados à própria natureza do conteúdo que se ensina e relacionados à ação didática.

Assim, como objetivo central da pesquisa, pretendemos investigar o uso de simulações computacionais em situações próximas àquelas formais da sala de aula, com o intuito de identificar obstáculos de aprendizagem no ensino de um tema específico de Física Moderna e Contemporânea: Estrutura da Matéria.

Três questionamentos direcionaram a pesquisa:

- Que obstáculos epistemológicos atuam no processo de ensinoaprendizagem sobre estrutura da matéria, em que são utilizadas simulações computacionais?

- De que forma as simulações computacionais estão envolvidas na emersão dos obstáculos epistemológicos?

- Que obstáculos didático-pedagógicos favoreceram a emersão dos obstáculos epistemológicos identificados?

\section{3- Estrutura do texto}

Considerando o capítulo introdutório em que se incluem estas linhas, a presente tese está dividida em dez capítulos, os quais, a partir do capítulo 2, estão distribuídos em quatro partes.

A primeira parte da tese, composta pelos capítulos 2 e 3, é dedicada a uma apresentação da natureza "fenômeno-técnica" dos conceitos de Física Moderna e Contemporânea, a uma descrição sobre a inserção de tais conceitos na educação em nível secundário, e a um apanhado sobre as Tecnologias da Informação e Comunicação e suas possibilidades de uso como ferramentas de ensino em aulas de Física que abordem conceitos de Física Moderna e Contemporânea. 
Em uma segunda parte do texto, composta pelos capítulos 4,5 e 6 , apresentamos as diferentes vertentes que compõem o nosso marco teórico: ideias provenientes de estudos sobre os modelos mentais e conceituais, sobre o uso de representações no ensino de ciências, e ideias inspiradas na epistemologia da ciência de Gaston Bachelard e na noção de obstáculos de aprendizagem de Guy Brousseau.

A terceira parte do texto, que é composta pelos capítulos 7 e 8 , é dedicada à apresentação dos métodos de desenvolvimento, coleta e análise de dados que foram empregados. Além disso, apresentamos os contextos de realização da pesquisa e descrevemos o curso sobre estrutura da matéria e aceleradores de partículas que compõe o pano de fundo de nosso estudo.

Por fim, na quarta parte do texto, que é composta pelos capítulos 9 e 10, apresentamos os resultados obtidos na pesquisa, as análises e discussões, e apresentamos as considerações finais, incluindo algumas possibilidades para trabalhos futuros. 


\section{PARTE I - FÍSICA MODERNA E CONTEMPORÂNEA E O USO DE TIC}

Nesta seção, apresentamos uma discussão sobre a natureza da Física Moderna e Contemporânea (FMC), e sobre o seu ensino na Educação Secundária.

Em seguida, apresentamos uma discussão sobre as Tecnologias da Informação e da Comunicação (TIC), com um destaque para as ferramentas computacionais e sua potencialidade para o ensino.

\section{2- A FÍSICA MODERNA E CONTEMPORÂNEA}

No início do século XX um novo paradigma emergiu no âmbito científico trazendo um conjunto de noções e conceitos que não eram conciliáveis com muitos dos elementos consagrados que sustentavam a ciência nos séculos anteriores. Este novo paradigma, baseando-se nas revelações e construções da Relatividade e da Física Quântica, apresentava-se como um saber que rompia de forma significativa, não somente com o conhecimento cotidiano e facilmente perceptível, mas também com o próprio conhecimento científico anterior: novidades como o princípio de incerteza, o tempo e espaços não mais como absolutos, a divisibilidade do átomo que passava a ser entendido como constituído por partes menores, entre outros; passaram a figurar como atores naquilo que hoje denominamos de Física Moderna'.

A Física do século XX e a Física atual (que integra a nova ciência) surgem em uma descontinuidade à ciência do século XIX. Além disso, o conhecimento na nova ciência passa a ser mais dependente da técnica: na construção do conhecimento a técnica empregada assume um papel significativo e, de certa forma, a técnica é parte própria do conhecimento. No subcapítulo 2.1, a seguir, discutimos a descontinuidade da nova ciência em relação à ciência clássica, e abordamos esta relação entre fenômeno e técnica que se torna mais estreita nesta nova ciência.

\footnotetext{
${ }^{1}$ Como não há uma definição muito clara sobre onde termina a Física Moderna e onde se inicia a Física Contemporânea, no restante do presente texto nos referimos às teorias e ideias modernas e contemporâneas da Física como parte de um mesmo conjunto, e assim, utilizamos o termo Física Moderna e Contemporânea.
} 


\section{1- O rompimento com a Física Clássica e com o conhecimento}

\section{comum: um conhecimento fenomenotécnico}

As novas características da Física que surgem com as teorias modernas e contemporâneas levam a uma necessidade de repensar a concepção sobre a Física e sobre a produção nesta ciência. Entre as correntes filosóficas de grande influência no início do século XX estava o positivismo, que ocupava um lugar de destaque no ambiente intelectual francês (BULCÃO, 2009, p.19; CASTELÃO-LAWLESS, 1995, p. 45). O positivismo sustenta uma visão continuísta da evolução da ciência, em que um conhecimento novo sempre é visto como completando o conhecimento anterior, em um acúmulo de conhecimentos. Além disso, apoiando-se no determinismo e na objetividade, e com uma forte herança da tradição mecanicista, o positivismo explicita previsibilidade: uma vez descrito o objeto científico que é dado, ele pode ter sua dinâmica prevista.

Em contraposição ao positivismo, os conceitos envolvidos na Física Moderna e Contemporânea que emergiam no início do século $X X$, em especial aqueles provenientes do que hoje conhecemos como Física Quântica, envolviam um indeterminismo e a aceitação de um conhecimento de natureza probabilística. Com isso, além das novas teorias físicas não poderem ser interpretadas em termos de uma evolução "positivista" de teorias anteriores, a própria noção positivista da ciência como conhecimento seguro ficava prejudicada: há um rompimento com a ideia clássica sobre o conhecimento científico, uma vez que a ciência antes exclusivamente determinista, objetiva e previsível, agora possui um nível de indeterminismo e uma objetividade probabilística. Nesse sentido, Castelão-Lawless (1995, p. 45) afirma que as indeterminações que as descobertas científicas sugeriram causaram novas preocupações epistemológicas sobre o caráter do conhecimento científico e suas conexões com a realidade física, levando a uma necessidade de novas atitudes metafísicas na filosofia da ciência, e a uma reavaliação dos modelos tradicionais da explicação científica e da mudança científica.

É neste contexto de inovação científica, acompanhada de uma necessidade de reavaliação das filosofias da ciência tradicionais, que surge o pensamento Bachelardiano. O filósofo da ciência francês Gaston Bachelard, nascido no final do século XIX, foi contemporâneo ao surgimento dessa nova Física. Para ele, os novos 
caminhos assumidos pela nova Física não poderiam ser expressos pelas vertentes filosóficas clássicas, como era o caso do positivismo (BARBOSA; BULCÃO, 2004, p. 20), ou por uma radicalização do idealismo ou do materialismo. Assim, o pensamento de Bachelard surge como uma contraposição à noção continuísta da evolução da ciência, à noção de uma realidade dada a qual a ciência moderna deveria descrever, e às posturas filosóficas absolutas. Seu pensamento se monta baseado em uma ideia construtivista da ciência, reconhecendo rupturas, e destacando a dialética existente na relação entre sujeito e objeto, e entre razão e realidade.

Ao introduzir a noção de ruptura, Bachelard contrapõe-se de forma explícita a visão da evolução da ciência como contínua. Conforme afirma Bulcão (2009, p. 47), para Bachelard o progresso da ciência se dá por "retificações de erros e por reorganizações do saber que rompem inteiramente com as teorias passadas", e não como uma contínua complementação das teorias passadas.

Como exemplo de ruptura, a mecânica quântica anteriormente citada, se elabora na primeira metade do século XX em contraposição direta às ideias da Física Clássica do século XIX. Por exemplo, a divisão clássica da matéria como partícula e da radiação como onda é um dos primeiros bastiões clássicos a ceder lugar ao conceito de dualidade onda-partícula. A Ciência Moderna do século XX viria a mostrar, com a noção de fótons, que a radiação poderia ser compreendida como tendo um comportamento corpuscular e, além disso, a matéria que antes era vista desde a perspectiva corpuscular é descrita pelo postulado de De Broglie em termos ondulatórios.

Cabe destacar que para Bachelard, essa ruptura não é uma negação total do passado, sendo mais caracterizado como um englobamento (BULCÃO, 2009, p. 198-199) ou "generalização dialética". Isso fica claro nas próprias palavras expressas por Bachelard na primeira metade do século XX em sua obra intitulada $A$ Filosofia do Não:

[...] A negação deve permanecer em contato com a formação primeira. Deve permitir uma generalização dialética. A generalização pelo não deve concluir aquilo que nega. De fato, todo o desenvolvimento do pensamento científico de há um século para cá provém de tais generalizações dialéticas com envolvimento daquilo que se nega. Assim a geometria não-euclidiana envolve a geometria euclidiana; a mecânica não-newtoniana envolve a mecânica newtoniana; a mecânica ondulatória envolve a mecânica relativista. No domínio da física, a constante de Planck $h$ surge como um 
fator de pequena desobediência relativamente às regras da ciência do senso comum. Como já várias vezes observamos, basta anular $h$ nas fórmulas da mecânica ondulatória para se obterem as fórmulas da mecânica clássica. A microfísica ou, por outras palavras, a não-física inclui, pois, a física. A física clássica é uma não-física particular correspondente ao valor zero atribuído a $h$ (BACHELARD, 1978, p.83).

Nessa visão da evolução descontínua da ciência em que são verificadas rupturas, Bachelard reconhece o conhecimento científico como um conhecimento aproximado. Sobre isso, Bachelard destaca que a história da ciência teria passado por um período concreto, um período concreto-abstrato e um período abstrato ${ }^{2}$, em que cada período consistiria em uma aproximação de determinada ordem.

Sobre a ciência moderna, esta seria um conhecimento aproximado de segunda ordem. Bulcão afirma que:

Bachelard mostra que a ciência contemporânea é um conhecimento de segunda aproximação que rompe com o real imediato e o conhecimento comum. Com o intuito de alcançar objetividade, a ciência se afasta dos dados imediatos e constrói, através de racionalizações e técnicas, um conhecimento inteiramente novo (BULCÃO, 2009, p. 196-197).

Ao interpretar a ciência moderna, Bachelard (1977, p. 13) percebe claras limitações no positivismo. Em suas palavras "[...] o positivismo puro já não pode justificar a força dedutiva em atuação no desenvolvimento das teorias modernas", afinal, ele "[...] nada tem para sentir essa estranha precisão de racionalidade que as aproximações de segunda ordem dão". Bachelard até aceita o positivismo como gerador de explicações aceitáveis para o período da ciência concreto-abstrato em que o espírito científico se sente seguro em suas abstrações quando estas podem ser representadas por uma intuição sensível, ou seja, em que a dedução racional pode ser facilmente percebida no experimento. Porém, uma aproximação de segunda ordem em que a percepção não é direta, algo característico da ciência moderna, não pode ser descrita desde a ótica positivista.

Ao perceber relações entre os períodos da ciência e as explicações de vertentes filosóficas, como o positivismo e sua visão da ciência do século XIX, Bachelard apresenta um olhar englobante, não restrito, em que destaca uma necessidade não extremista na leitura filosófica da ciência moderna. Sobre isso, Rheinberger afirma que Bachelard situou-se:

[...] para além das marcas concebidas da filosofia da ciência: para além do positivismo e do formalismo, o empirismo e o convencionalismo, realismo e

\footnotetext{
${ }^{2}$ Bachelard descreve tais etapas no discurso preliminar de sua obra A formação do espírito científico.
} 
idealismo, posições que ele julgou serem o resultado de abstrações inadmissíveis que não fazem justiça à complexidade das ciências contemporâneas. Ele não queria estar ao lado com qualquer uma destas tradições filosóficas. A fim de expressar a tensão dialética em sua própria abordagem, ele a chamou de "racionalismo aplicado" ou "materialismo técnico" (RHEINBERGER, 2005, p. 316-317, tradução nossa).

Essa dialética entre vertentes filosóficas é uma marca da epistemologia de Bachelard. Como exemplo, sobre o racionalismo e o empirismo e o pensamento científico moderno, Bachelard afirma:

Se pudéssemos então traduzir filosoficamente o duplo movimento que
atualmente anima o pensamento científico, aperceber-nos-íamos de que a
alternância do a priori e do a posteriori é obrigatória, que o empirismo e o
racionalismo estão ligados, no pensamento científico [...] Com efeito, um
deles triunfa dando razão ao outro: o empirismo precisa de ser
compreendido; o racionalismo precisa de ser aplicado. Um empirismo sem
leis claras, sem leis coordenadas, sem leis dedutivas não podem ser
pensado nem ensinado; um racionalismo sem provas palpáveis, sem
aplicação à realidade imediata não pode convencer plenamente. O valor de
uma lei empírica prova-se fazendo dela a base de um raciocínio. Legitima-
se um raciocínio fazendo dele a base de uma experiência. (BACHELARD,
1978, p.4-5)

Sua epistemologia dialética também passa por uma profunda reflexão sobre a realidade e os objetos da ciência. Segundo Bachelard, enquanto o realismo e o idealismo, em certa medida, permitem uma interpretação do conhecimento comum e do conhecimento oriundo da ciência clássica, o extremismo dessas posições não é suficiente para explicar a ciência moderna.

Antes de nos determos à insuficiência de explicação da ciência moderna por um extremismo dessas vertentes filosóficas, julgamos necessário diferenciá-las e, ao mesmo tempo, defini-las. O ponto principal de divergência entre o realismo e o idealismo está na primazia ou da realidade objetiva, ou das ideias. Enquanto para o realismo o dado primordial para constituir o conhecimento situa-se na realidade objetiva do mundo, ou seja, nos objetos que povoam o mundo externo à mente; no idealismo o mundo exterior à mente é apenas uma imagem do mundo das ideias e, portanto, é conferida primazia às ideias, ou seja, ao subjetivo e não ao objetivo.

O realismo possui ainda uma relação com a corrente filosófica conhecida como materialismo. Uma vez que o materialismo encara a realidade como fora do plano das ideias, ele é uma forma de realismo. Destaca-se, no entanto, que para o materialismo a realidade seria somente a realidade material, ou que pode ser materializada. Em outras palavras, para o materialismo a substância única da realidade é a matéria, que é independente do sujeito. Dessa afirmativa pode-se 
concluir facilmente que nem todo realista é materialista, mas todo materialista é realista, afinal o realismo só diz respeito à primazia da realidade objetiva e não especifica a realidade como sendo exclusivamente material.

Dessas definições podemos afirmar que o positivismo tem um componente materialista, pois o objeto científico dado é um objeto material ou materializado que poderá ser investigado. No entanto, podemos dizer também que o próprio positivismo já rompe com o extremismo ou com a exclusividade do realismo ou do materialismo. Para o positivismo, ao mesmo tempo em que o objeto científico real é aceito como dado, e deve-se descrevê-lo por meio do uso de um processo experimental (o que levaria o positivismo a ser em certa medida realista), faz-se também uso de uma racionalização em que por processos lógicos pode-se prever algo e definir a experimentação mais adequada a capturar o seu significado mais objetivo (o que levaria o positivismo às proximidades de um idealismo).

Como dissemos, Bachelard se opõe a essas diferentes vertentes para explicar a ciência contemporânea, mas ao mesmo tempo as engloba em uma dialética que possui como um dos pontos centrais os objetos científicos. Conforme bem apresenta Bachelard, na ciência moderna não mais se reproduz uma realidade, mas uma nova realidade é inventada. O objeto científico não é oferecido à percepção como algo imediato, mas é o resultado de um projeto, de um modelo teórico que leva o cientista a uma realidade. Porém, o mesmo projeto é elaborado e montado baseando-se na realidade construída. É um processo pelo qual a objetividade é construída e conquistada, e não oferecida (BARBOSA, BULCÃO, 2004, p.37-39).

Como exemplo, partículas subatômicas ou o comportamento corpuscular da luz não são diretamente e naturalmente acessíveis aos sentidos, mas são construídos enquanto uma realidade tecnicamente acessível. Trata-se, portanto, de uma realidade científica duplamente construída, pela técnica e pela teoria, pela racionalização e pela materialização. Assim, torna-se evidente no pensamento bachelardiano a dialética necessária entre as vertentes filosóficas: há uma realidade materialista, ainda que seja construída mediante a racionalização, que por sua vez, necessita da aplicação para ser coerente, ou seja, necessita de uma materialização. A materialização, por sua vez, alimenta a racionalização. Logo, há um diálogo em que racionalismo e realismo não ocupam um papel fixo a priori, mas um diálogo que 
não é propriamente determinado pela razão nem por um objeto dado, mas determinado pela interação entre eles. Essa dialética leva Bachelard a interpretar a ciência moderna como um materialismo racional ou um racionalismo aplicado.

Esse processo dialético entre razão e realidade ainda emprega algo que para Bachelard assume relevância: a técnica. Na ciência moderna busca-se, mediante racionalizações e técnicas uma realidade, uma fenomenologia. Os equipamentos empregados na ciência moderna, especialmente no mundo atômico e subatômico, permitem chegar indiretamente a um fenômeno que é racionalmente previsto e que é tecnicamente construído pelos próprios equipamentos. Não se está mais lidando com uma "realidade natural", mas com o produto das técnicas, sendo estas por sua vez, resultado de uma aplicação teórica.

Assim, por um conhecimento tecnicamente e teoricamente instruído, a ciência moderna deixa de ser explicada pelos sentidos e passa a ser explicada por seus aparelhos, e a realidade deixa ser dada para ser uma realidade construída, mas ainda assim mantêm-se como uma realidade científica. Conforme afirma Lopes (1994, p. 338) "[...] o fenômeno científico é, portanto, construído pela dupla interpretação, instrumental e teórica, uma aplicada à outra". Diferenciando da realidade fenomênica dada e diretamente acessível, Bachelard define a realidade construída na ciência moderna mediante racionalizações e técnicas como uma realidade fenomenotécnica. Segundo ele, e indo ao encontro do que já expusemos, na ciência moderna:

É preciso haver outros conceitos além dos conceitos "visuais" para montar uma técnica do agir cientificamente-no-mundo e para promover à existência, mediante uma fenomenotécnica, fenômenos que não estão naturalmentena-natureza. Só por uma desmaterialização da experiência comum se pode atingir um realismo da técnica científica (BACHELARD, 1977: 160).

Assim, a realidade fenomenotécnica que é uma consequência de uma interrelação próxima entre técnica e conhecimento, consiste em uma instrução múltipla em que fenômeno e instrumento, objeto e espírito científico, conceito e método estão todos unidos (RHEINBERGER, 2005, p. 320).

Ao longo de sua obra Bachelard apresenta alguns exemplos em sua descrição da ciência moderna, diretamente relacionados com a noção de fenomenotécnica. Em O Racionalismo Aplicado, Bachelard (1977, p. 122-123) compara a realidade dada pela balança, de caráter fenomênico, com a realidade 
construída pelo espectroscópio de massa, de caráter fenomenotécnico. Enquanto na determinação dos pesos atômicos por Lavoisier há a técnica mais direta e suficiente da balança $^{3}$, no espectroscópico de massa, ao se selecionar e pesar isótopos há uma técnica indireta que se baseia em campos elétricos e magnéticos. Segundo Bachelard (1977, p. 122), enquanto a ciência de Lavoisier está "[...] em ligação contínua com os aspectos imediatos da experiência usual", no espectroscópio de massa, em que se acrescenta um eletrismo ao materialismo e como os fenômenos elétricos dos átomos estão ocultos, faz-se necessário "[...] instrumentá-los numa aparelhagem que não tem significação direta na vida comum".

Bachelard (1977, p. 123), enfatizando a realidade construída mediante a técnica, destaca ainda que "As trajetórias que permitem separar os isótopos no espectroscópio de massa não existem na natureza; é preciso produzi-las tecnicamente". É uma existência realizada pela técnica, portanto, constituindo-se não como um fenômeno natural, mas como uma fenomenotécnica.

São muitos os fenômenos descritos na Física Moderna e Contemporânea instrumentalizados em uma aparelhagem, isto é, que não existem naturalmente e que são realizados tecnicamente, envolvendo assim uma realidade fenomenotécnica: colisão envolvendo partículas subatômicas ou íons em altas velocidades no interior de aceleradores de partículas; centelhamento de partículas alfa ao encontrar-se com o sulfeto de zinco após um espalhamento tecnicamente elaborado (Experimento de Geiger-Marsden); difração de raios X com o uso de estruturas cristalinas; entre outros.

Pela relação próxima entre a realidade construída e a tecnologia empregada na ciência moderna, o conhecimento fenomenotécnico envolve ainda uma não distinção clara entre estes. Nesse sentido, Castelão-Lawless (1995, p.51) afirma que na ciência moderna, uma ciência que gera conhecimento fenomenotécnico, em que os instrumentos são materializados em teorias, não há uma diferença qualitativa entre os produtos da ciência e da tecnologia científica.

Ao definirmos como fenomenotécnico o conhecimento da Física Moderna e Contemporânea (FMC), assumimos duas questões importantes: (1) este

\footnotetext{
${ }^{3}$ Em A Filosofia do Não, Bachelard (1978, p. 15) afirma que como a balança é utilizada antes mesmo que se conhecesse a teoria da alavanca, o conceito de massa seria direto, formando-se, ainda que com o uso da balança, como uma experiência primeira em uma realidade dada.
} 
conhecimento se constrói sobre uma realidade também construída, não acessível no mundo cotidiano que, portanto, rompe com o imediato; (2) no entendimento dos conceitos provenientes das teorias modernas e contemporâneas é relevante a compreensão da técnica enquanto conhecimento aplicado.

\subsection{1- Aceleradores de partículas, estrutura da matéria e}

\section{fenomenotécnica}

Entre os equipamentos utilizados na ciência moderna, os aceleradores de partículas assumem uma notabilidade, sendo fundamentais nas áreas da Física de Partículas e Física Nuclear, sem os quais tais áreas não teriam se desenvolvido muito. Conforme afirmam Das e Ferbel (2003, p.183-184), não somente a Física de Partículas e a Física Nuclear se beneficiam dos aceleradores de partículas, mas estes são utilizados em uma variedade de aplicações, como em experimentos em Física de Matéria Condensada, em áreas biomédicas, em Geofísica, na indústria eletrônica, entre outros.

Os aceleradores de partículas são máquinas, normalmente de grandes dimensões, que com o uso de campos elétricos conseguem acelerar partículas (subatômicas ou íons) a grandes velocidades, e com o uso de campos magnéticos as direciona até colidirem contra um alvo. Com a colisão obtêm-se radiações que podem ser utilizadas para variados fins, e geram-se novas partículas que podem ser identificadas por sensores. Os aceleradores de partículas podem ser divididos em vários tipos, segundo a tecnologia empregada e a forma como as partículas são aceleradas e colidem: eletrostáticos, cíclotrons, lineares, betatrons, síncrontrons e colidores (SESSLER; WILSON, 2007) ${ }^{4}$.

Muitas das partículas subatômicas obtidas no interior dos aceleradores de partículas possuem um tempo de vida curto e/ou não se manifestam com frequência no mundo cotidiano. Além disso, as partículas subatômicas são de dimensões imperceptíveis diretamente aos sentidos humanos. Assim, os aceleradores de partículas são um exemplo de técnica no sentido bacherladiano que permite a construção de uma realidade científica, realidade esta que não possui referentes no cotidiano e que só é acessível mediante o acumulado técnico-teórico presente no

\footnotetext{
${ }^{4}$ Para um aprofundamento sobre os aceleradores de partículas, recomendamos o livro Engines of Discovery: a century of Particle Accelerators, escrito pelo pesquisador Andrew Sessler do Lawrence Berkeley National Laboratory (LBL) e pelo pesquisador Edmund Wilson do European Organization for Nuclear Research (CERN).
} 
conhecimento disponível. Vale destacar ainda que muitas das predições teóricas oriundas das áreas de Física de Partículas e Física Nuclear se realizam mediante os aceleradores de partículas e, também, muito dos resultados obtidos experimentalmente permitem um refinamento do conhecimento científico em constante construção.

Apesar de aceleradores de partículas serem um exemplo flagrante de fenômenos-técnicas, vários outros equipamentos foram utilizados para a realização de experimentos, especialmente a partir de meados do século XIX, os quais envolviam entidades não perceptíveis diretamente pelos sentidos. Um exemplo historicamente relevante é o experimento de Geiger-Marsden que levou Rutherford a propor um novo modelo atômico no início do século XX, contribuindo para o estudo sobre a estrutura da matéria. Tal experimento envolvia partículas alfa que eram imperceptíveis a olho nu, mas que podiam ser verificadas experimentalmente em sua interação com um determinado material, o sulfeto de zinco. O conhecimento obtido a partir dos aceleradores de partículas e nos muitos experimentos realizados por décadas no estudo da estrutura da matéria, envolve fenômenos-técnicas que para seu entendimento, não se pode separar qualitativamente o objeto de estudo dos meios empregados para estudá-lo.

No subcapítulo 2.2, a seguir, discutimos a inserção de conceitos de Física Moderna e Contemporânea (FMC) na Educação Secundária como conteúdos a serem ensinados. Apresentamos um breve panorama da literatura sobre esta inserção, algumas reflexões sobre como ensinar tais conceitos, e focamo-nos em seguida na possibilidade de uso de recursos computacionais para a representação dos objetos que compõem o conhecimento oriundo da FMC.

\section{2- A Física Moderna e Contemporânea na Educação Secundária}

Discussões no meio acadêmico sobre a inserção da Física Moderna e Contemporânea na Educação Secundária ${ }^{5}$ já vêm sendo feitas há algumas décadas (KNECHT, 1968; MARX, 1975) e atualmente essa inserção é aceita de forma praticamente consensual entre os pesquisadores em ensino de ciências (LOBATO;

\footnotetext{
${ }^{5}$ Como a discussão sobre a inserção da Física Moderna e Contemporânea é mais ampla, não se limitando ao contexto brasileiro, no presente texto optamos pelo uso do termo mais geral "Educação Secundária" em lugar de "Ensino Médio". Isso se torna ainda mais pertinente pelo fato da pesquisa aqui tratada envolver dois contextos, o paulista e o catalão (Espanha), não se limitando, portanto, à Educação Secundária brasileira, ou seja, ao Ensino Médio.
} 
GRECA, 2005). Três questionamentos permeiam qualquer seleção de conteúdo a ensinar e são relevantes na discussão sobre a inserção da FMC na Educação Secundária: "Por que ensinar?", "O que ensinar?" e "Como ensinar?".

Em relação ao porquê de se ensinar a FMC na Educação Secundária, diversos pesquisadores em ensino de Física expõem muitas razões ao defenderem uma necessidade de uma renovação curricular que inclui a inserção da FMC na Educação Secundária (GIL; SENENT; SOLBES, 1987, 1989; AUBRECHT, 1989; STANNARD, 1990; FISCHLER; LICHTFELDT, 1991, 1992; KALMUS, 1992; WILSON, 1992; SWINBANK, 1992; TERRAZZAN, 1992; GIL; SOLBES, 1993; CUPPARI et al., 1997, BAROJAS, 1998; OSTERMANN; MOREIRA, 2000; BROCKINGTON; PIETROCOLA, 2005; BROCKINGTON et al., 2008; SIQUEIRA; PIETROCOLA, 2011).

Ostermann e Moreira (2000, p. 391-392) apresentam uma síntese das principais razões presentes na literatura:

- Desperta a curiosidade dos alunos e os ajuda a reconhecer a física como um empreendimento humano e, portanto, próximo a eles;

- Os estudantes não têm contato com o excitante mundo da física atual, pois a física que veem não passa de 1900. Esta situação é inaceitável em um século o qual ideias revolucionárias modificaram totalmente a ciência;

- É necessário motivar os jovens para a carreira científica. São eles os futuros professores e pesquisadores em física. A física moderna e contemporânea é a que mais pode influenciar os estudantes a escolherem a física como carreira profissional;

- Os estudantes ouvem falar de temas como buracos negros e Big Bang na televisão ou em filmes de ficção científica, mas jamais nas aulas de física;

- A física moderna é considerada difícil e abstrata; contudo, as pesquisas em ensino de física têm mostrado que a física clássica também é difícil e abstrata para os alunos, os quais apresentam sérias dificuldades conceituais para compreendê-la;

- O ensino de temas atuais da física pode contribuir para transmitir aos alunos uma visão mais correta dessa ciência e da natureza do trabalho científico, superando a visão linear, claramente acumulativa do desenvolvimento científico que impregna os livros de texto hoje utilizados e as aulas de Física. (OSTERMANN; MOREIRA, 2000, p. 391-392, tradução nossa).

Reconhecemos que, apesar dessa ampla defesa que responde ao porquê de se inserir a FMC na Educação Secundária, há certamente diversos 
questionamentos sobre a possibilidade dessa inserção, que são expostos principalmente por professores. Tais questionamentos se baseiam em parte nas características da própria FMC ou nas limitações próprias da estrutura escolar. No entanto, enquanto as características da FMC não seriam, propriamente, um contraponto ao porquê de se ensinar, mas sim algo mais atrelado à discussão sobre "como ensinar" (que trataremos mais adiante), as limitações próprias da estrutura escolar situam-se em um panorama mais amplo que, igualmente, não implicariam em uma invalidação dos porquês de se ensinar FMC na Educação Secundária. Por exemplo, limitações como o pouco tempo reservado para a disciplina de Física ou o despreparo dos alunos que chegam à Educação Secundária, presentes no discurso dos professores quando questionados sobre a inserção da FMC na Educação Secundária (MONTEIRO et al.; 2009), remetem a um problema mais amplo na estrutura da educação escolar, o qual atua como um empecilho não somente ao ensino da FMC, mas à disciplina de Física de maneira geral. Neste sentido, ainda que reconheçamos como existentes os questionamentos contrários à inserção, por situá-los em um plano diferente do "Por que ensinar?" e amparados na ampla defesa presente na literatura, assumimos neste trabalho que a pergunta sobre o porquê de se ensinar a FMC na Educação Secundária já é algo respondido e aceito, de forma que não nos estenderemos em buscar novas razões ou em validar aquelas já expostas.

Uma vez que consideremos superado o porquê, o segundo questionamento torna-se pertinente: “O que ensinar de FMC na Educação Secundária?". Não entendemos este questionamento como totalmente respondido, mas conforme apontam Ostermann e Moreira (2000, p. 392), há na literatura uma indicação de conteúdos que se concentram em tópicos de relatividade, mecânica quântica e partículas elementares.

Como exemplo, o Núcleo de Pesquisa em Inovação Curricular (NUPIC) da Faculdade de Educação da Universidade de São Paulo tem desenvolvido há alguns anos pesquisas sobre o ensino de tópicos de FMC na Educação Secundária, como Física de Partículas Elementares (SIQUEIRA; PIETROCOLA, 2007), as bases da Mecânica Quântica na Dualidade Onda-Partícula (BROCKINGTON; PIETROCOLA, 2007), Física das Radiações (SOUSA, 2009), Relatividade (BROCKINGTON et. al., 2007a; 2007b) e o Paradoxo dos Gêmeos (PIETROCOLA et. al., 2012). 
Além do que é indicado na literatura, já existem propostas curriculares que citam conteúdos específicos de FMC como conteúdos a serem ensinados. Como exemplo, o currículo oficial do estado de São Paulo (SÃO PAULO, 2008) já inclui conceitos de Física Moderna e Contemporânea em meio aos conteúdos a serem abordados no Ensino Médio. Nos $3^{\circ}$ e $4^{\circ}$ bimestres do $1^{\circ}$ ano do Ensino Médio paulista, prevê-se que sejam tratados tópicos de cosmologia como evolução estelar e teorias e modelos de origem e constituição do universo. Nos $3^{\circ}$ e $4^{\circ}$ bimestres do $3^{\circ}$ ano do Ensino Médio paulista, são previstos também variados tópicos relacionados à Física Quântica e Estrutura da Matéria, como propriedades e organização da matéria, o átomo e a emissão e absorção da radiação, núcleo atômico e radioatividade, partículas elementares, e a eletrônica.

Assim, ainda que a seleção dos conteúdos de FMC não seja um consenso, pelas temáticas indicadas na literatura e a partir do que já é previsto em alguns currículos oficiais (CATALUNYA, 2008; SÃO PAULO, 2008) assumimos que conteúdos como aqueles relacionados ao tópico Estrutura da Matéria, que é abordado em nossa pesquisa, são relevantes para serem ensinados na Educação Secundária.

Sobre como ensinar os conteúdos de FMC, especificamente em relação às abordagens metodológicas, uma vertente que cabe ser destacada pela sua relevância para a presente pesquisa envolve a exploração dos limites da Física Clássica. Situados nesta vertente metodológica, Gil e Solbes (1993) sugerem uma abordagem construtivista na qual são apresentadas aos alunos situações problemáticas através das quais se pretende que seja construído o conhecimento. Na mesma linha, Neto, Freire Jr e Rocha (1999) defendem também a exploração dos limites clássicos como estratégia para a introdução de tópicos de FMC, e apresentam resultados de uma experiência didática implementada.

Acreditamos que a exploração dos limites da Física Clássica apresenta-se como uma estratégia potencial para a inserção da FMC na Educação Secundária. Primeiro, por entendermos que conceitos e operações da Física Clássica podem, em muitas situações, servir de ponto de partida para a aprendizagem de conceitos de Física Moderna e Contemporânea. Por exemplo, para a compreensão/construção do conceito de dualidade onda-partícula da luz, pode ser necessário que o aluno saiba definir e diferenciar fenômenos corpusculares e ondulatórios e ainda, saiba operar 
conceitos clássicos de Física ondulatória como frequência, comprimento de onda, intensidade, amplitude, interferência, etc., e conceitos corpusculares como trajetória, posição e indivisibilidade (PIETROCOLA, 2005; BROCKINGTON; SIQUEIRA; PIETROCOLA, 2007). Assim, adotamos a perspectiva de que na exploração dos limites da Física Clássica como estratégia para o ensino de FMC, o conhecimento de conceitos da Física Clássica constitui-se como um pré-requisito para o ensino dos conceitos da Física Moderna e Contemporânea. Além disso, conforme descrevemos no subcapítulo 2.1, como o conhecimento da Física Moderna e Contemporânea rompe e ao mesmo tempo engloba o conhecimento da Física Clássica, aceitamos que o entendimento pleno da FMC se dá por uma contraposição e comparação com o conhecimento clássico, e não por uma simples adição e assimilação de novos conceitos e novas explicações ${ }^{6}$. Segundo, em uma abordagem em que se exploram os limites da Física clássica, há a possibilidade de um maior envolvimento por parte dos alunos, visto que estarão em meio a um processo de identificação de contradições com a Física clássica, em que eles próprios, com o auxílio do professor e das ferramentas pedagógicas, podem buscar explicações para tais contradições (PIETROCOLA, 2008).

Além das abordagens metodológicas, quando se pensa no "como ensinar", há de se considerar ferramentas e estratégias que permitam tratar o conhecimento da FMC, de forma a garantir o ensino e a aprendizagem destes conteúdos na Educação Secundária. Algumas pesquisas procuraram avaliar estratégias de ensino de conteúdos de FMC na educação básica, já apresentando resultados preliminares (ARRUDA et al., 1997; TAYLOR et al., 1998; CUSTÓDIO; ZANETIC, 1999; COSTA; SANTOS, 1999; OSTERMANN; CAVALCANTI, 1999; TABER, 2004; OGBORN, 2005; AMBROSIS; LEVRINI, 2007; BROCKINGTON; SIQUEIRA; PIETROCOLA, 2007; SOUSA et al., 2007; BROCKINGTON; PIETROCOLA, 2008; BROCKINGTON et. al., 2008; NICOLAU JUNIOR; BROCKINGTON; SASSERON, 2011; SIQUEIRA; PIETROCOLA, 2012).

Conforme nos dedicamos a descrever no subcapítulo 2.1, a Física Moderna e Contemporânea rompe com a ciência clássica e com o senso comum, e constróise a partir de fenômenos criados mediante a técnica. Assim, os conceitos

\footnotetext{
$6 \quad$ Neste sentido, nos opomos à corrente dos pesquisadores, como Fischer e Lichtfeldt (1991, 1992), que sustentam que se pode aprender/ensinar conceitos de FMC sem previamente conhecer ou estudar a Física Clássica.
} 
envolvidos na FMC possuem um alto grau de abstração, não possuem relativos claramente perceptíveis no mundo cotidiano, e estão relacionados com fenômenos que exigem muitas vezes equipamentos sofisticados e caros para serem reproduzidos. Além disso, conforme afirmam Pietrocola e Brockinton (2003), abordar o mundo da FMC implica em extrapolar o domínio dos sentidos mais imediatos, afinal, os conceitos envolvidos se apresentam como contra intuitivos.

Logo, ao pensarmos em ferramentas favoráveis ao ensino desse conteúdo, podemos considerar aquelas que irão suprir as dificuldades naturais do próprio conteúdo. Ou seja, que permitam uma representação do objeto de estudo, da técnica envolvida, e que possam ser utilizados em meio a discussões centradas na superação de noções prévias aprendidas no estudo da Física Clássica ou a partir da experiência cotidiana. Entre as ferramentas disponíveis atualmente, identificamos algumas daquelas envolvidas nas Tecnologias da Informação e Comunicação (TIC) como suficientes para suprir as dificuldades naturais do conteúdo de FMC. Por exemplo, as animações e simulações computacionais permitiriam acessar a técnica desenvolvida pelos cientistas, permitiriam acessar uma representação dinâmica dos objetos e entidades físicas que compõem a FMC e, ainda, poderiam ser incluídas em meio a atividades que permitissem uma discussão que levasse à construção do conhecimento de FMC. No entanto, sendo a FMC um conhecimento de segunda aproximação, pode-se pensar não somente no uso destas ferramentas que busquem representar as entidades e a técnica empregada na FMC, mas também podem ser utilizados experimentos reais, que explorem uma primeira aproximação mediante a Física Clássica, os quais permitam uma introdução às técnicas de inferência indireta empregadas na FMC.

Além de considerarmos que as novas ferramentas tecnológicas podem ser utilizadas para representar os objetos de estudo e os fenômenos envolvidos na FMC, suprindo as dificuldades de percepção e abstração próprias da FMC, acreditamos que o próprio ensino da Física Moderna e Contemporânea, como é o caso do tema Estrutura da Matéria, constitui-se como um contexto especialmente favorável ao uso de simulações computacionais e ao estudo sobre aspectos envolvidos neste uso.

Dada a relevância das Tecnologias da Informação e Comunicação (TIC) nesta pesquisa, dedicamos o capítulo 3, a seguir, a apresentar uma visão geral 
sobre o uso das TIC na educação. Inicialmente destacamos algumas das razões principais que são comumente apontadas para se utilizar as TIC na Educação. Ainda que não retomemos tais razões depois nesta pesquisa, pois estas não possuem uma relevância direta para os objetivos da pesquisa, acreditamos que elas fazem parte de um contexto atual que tem favorecido o uso de TIC e que, portanto, valem ser destacadas. Também apresentamos no próximo capítulo algumas categorias de TIC e de recursos computacionais, entre as quais se situam as simulações computacionais. 


\title{
3- TECNOLOGIAS DA INFORMAÇÃO E COMUNICAÇÃO NA EDUCAÇÃO
}

As Tecnologias da Informação e Comunicação $^{7}$ (TIC) possibilitam criar, armazenar, gerenciar e disseminar a informação de forma facilitada por meios eletrônicos. Tecnologias como a computação, a Internet, a televisão, o rádio, a telefonia celular, entre outros, podem ser considerados como TIC. Algumas das principais características das TIC são: a interatividade, o fato de poderem ser utilizadas a qualquer momento, seu longo alcance, e o fato de apresentarem um custo de uso reduzido se comparadas a outras tecnologias (GERSTER; ZIMMERMANN, 2003).

Ainda que nesta pesquisa não nos detenhamos em uma discussão política e social sobre o papel das TIC na educação, para melhor caracterizar o contexto amplo em que se insere qualquer pesquisa sobre o uso de novas tecnologias na educação, destacamos algumas das razões que têm sido apontadas frequentemente para se inserir as TIC na escola.

Segundo a Organisation for Economic Co-operation and Development (OECD, 2001, p. 10-11), existem razões de ordem econômica, social e pedagógica para incluir o uso das TIC na educação. Do ponto de vista econômico, pode-se dizer que cada vez mais, diferentes áreas têm incluído e utilizado as TIC. Segundo a OECD (2001, p. 10) há um consenso global de que as nações que estão receptíveis à era da informação irão se beneficiar economicamente.

Além disso, Ponte (2000, p. 65) afirma que:

\begin{abstract}
Novas actividades econômicas dependem fortemente destas tecnologias, desde a prestação de serviços através da Internet, às comunicações, passando pelo comércio electrónico e pelas empresas de desenvolvimento de «conteúdos», entretenimento e software. As empresas da chamada nova economia digital - informática e telecomunicações - assumiram uma proeminência de tal ordem que se constituiu um índice à parte para as respectivas cotações bolsistas (PONTE, 2000, p. 65).
\end{abstract}

\footnotetext{
${ }^{7}$ Nesta pesquisa entendemos que as Tecnologias da Informação e Comunicação são ferramentas que privilegiam o tratamento da informação e/ou permitem a comunicação. Assim, ferramentas que possuam ênfase unicamente no tratamento da informação ou na comunicação, seriam também consideradas como TIC. Como exemplo, consideramos como TIC as simulações computacionais: estas permitem o tratamento da informação, independente do uso de alguma outra ferramenta de comunicação, como é o caso da Internet.
} 
A sociedade contemporânea é, sem dúvida, uma sociedade da informação. Logo, é inevitável afirmar que há uma necessidade de formação de pessoas que possam lidar com estas múltiplas tecnologias. E esta necessidade possui como componentes não somente elementos econômicos, mas sociais. O conhecimento e a familiaridade com as TIC é um importante aspecto de empregabilidade. Ponte (2000) afirma que não somente as atividades empresariais e econômicas têm se tornado cada vez mais tecnológicas, mas também as atividades cotidianas também empregam cada vez mais os recursos tecnológicos. Segundo este autor:

Estas tecnologias não se limitam à vida das empresas. Elas invadiram o
nosso quotidiano. Obtemos dinheiro nas caixas bancárias automáticas,
pagamos as nossas despesas em qualquer parte do mundo com dinheiro
através dos cartões, usamos telefones celulares, compramos os nossos
bilhetes de avião através do nosso computador (PONTE, 2000, p. 65).

Logo, pode-se concluir que conhecer e saber lidar com as TIC são, cada vez mais, pré-requisitos para a participação e trabalho na sociedade. Nesse sentido, desenvolver competências de uso das TIC adquire um papel de "habilidade vital", assim como saber ler, escrever e lidar com números (BAWDEN, 2001; SELWYN, 2008). Em outras palavras, o que já se conhece como alfabetização digital é uma necessidade dos tempos atuais. Além disso, a própria escola, como uma instituição da sociedade contemporânea, deveria buscar uma proximidade com os processos comunicativos atuais. Neste sentido, não ocorrendo esta proximidade, não é incomum o descontentamento dos alunos com o que a escola pode fornecer (OECD, 2001, p. 11).

No que se refere às razões pedagógicas para inserir as TIC no contexto escolar, muitas são aquelas apresentadas por estudiosos da educação e das TIC, professores, gestores públicos, entre outros. Uma razão que diríamos ser comum é a motivação para a aprendizagem que as TIC podem proporcionar. O que se afirma aqui é que a interação envolvida no uso das TIC, assim como o aspecto lúdico que muitas vezes está presente neste uso, seriam potenciais elementos que ocasionariam o engajamento e o interesse dos alunos para a aprendizagem.

As razões pedagógicas também passam pelo campo de estudo da cognição e neurociências. Segundo Small e Vorgan (2008, p.1), a corrente explosão da tecnologia digital, um tipo específico das TIC que inclui os computadores e a Internet, está mudando não somente nossas vidas, mas também está alterando 
rapidamente e profundamente os nossos cérebros. Além de influenciar o modo como pensamos, a tecnologia digital está alterando a maneira como nos sentimos, como nos comportamos, e a maneira como o nosso cérebro funciona. Small e Vorgan (2008, p. 21-26) afirmam que os circuitos neurais que controlam os métodos mais tradicionais de aprendizagem são negligenciados e gradativamente têm diminuído, se tornando menos desenvolvidos. Considerando este aspecto, não é uma surpresa que muitos estudantes reconheçam que o aprendizado em sala de aula e o sistema tradicional de ensino baseado muitas vezes na estratégia expositiva, sejam entediantes. Assim, a inserção de novas tecnologias como as TIC, em especial os computadores, seria uma forma de explorar os novos métodos de aprendizagem que os nativos digitais do mundo atual estão capacitados a acompanhar.

Com base nessas razões, ou mesmo a partir de uma percepção talvez já presente no senso comum de que as novas tecnologias da informação e comunicação assumiriam um papel importante na educação, governos têm implementado iniciativas de inserção de novas tecnologias na educação pública. Um exemplo no Brasil é o Programa Nacional de Tecnologia Educacional (Prolnfo), que tem como objetivo promover o uso pedagógico da informática na rede pública de educação básica, inserindo nas escolas computadores, recursos digitais e conteúdos educacionais (BRASIL, 2013).

Conforme afirmam Prata, Nascimento e Pietrocola (2007), com os programas e ações governamentais que têm sido pensados e implantados, "... novas e ricas oportunidades pedagógicas surgem com a possibilidade de uso de recursos digitais atraentes para as atividades curriculares", por exemplo, para o uso dos chamados objetos de aprendizagem. Tais recursos digitais possuem características bem definidas (CHURCHILL, 2007), e incluem alguns tipos de ferramentas computacionais, como as simulações computacionais.

No subcapítulo 3.1, a seguir, descrevemos algumas das ferramentas computacionais que podem ser utilizadas na educação. 


\section{1- Ferramentas computacionais}

Como comentamos anteriormente, o computador e a Internet compõem apenas uma parte do conjunto de Tecnologias da Informação e da Comunicação. São várias as ferramentas computacionais, dependentes ou não da Internet, que podem ser utilizadas na educação. Em nossa pesquisa, em que estudamos situações de uso de simulações computacionais, logicamente não abordaremos todas as possibilidades tecnológicas. No entanto, podemos destacar outras ferramentas que encontram lugar neste contexto de inovação tecnológica dos processos educacionais. Pintó, Couso e Hernández (2010, p. 3-4) apresentam uma lista destas ferramentas, em grande parte compostas por categorias de softwares que podem ser utilizados na educação presencial:

- Softwares para criar tarefas interativas - Com este tipo de software, professores podem criar e gerenciar diferentes tipos de atividades e tarefas, tais como questões de múltipla escolha, palavras cruzadas, preenchimento de lacunas, ligação entre perguntas e respostas, entre outros. Em geral, nestas atividades os alunos podem escolher ou indicar uma resposta que julgue a correta para uma determinada questão. É inegável que tal ferramenta tecnológica ocupa um papel mais próximo aos meios tradicionais de ensino e avaliação, de forma que, um ensino por memorização acaba por ser privilegiado com este tipo de ferramenta tecnológica.

- Softwares para representar e organizar o conhecimento - Neste tipo de software, que não é propriamente (ou exclusivamente) uma ferramenta de ensino e aprendizagem, o conhecimento pode ser representado, organizado e inter-relacionado graficamente. Podem ser classificados como este tipo de software, aplicativos para a construção de mapas conceituais, mapas mentais, diagramas $V$ de Gowin, entre outros. Tais softwares podem permitir aos alunos conhecer melhor a estrutura e estabelecer relações entre diferentes partes de seu próprio conhecimento.

- Softwares para a visualização de sistemas e fenômenos (animações computacionais) - Tais aplicativos consistem em imagens dinâmicas que buscam representar algum fenômeno ou sistema. É uma ferramenta especialmente útil ao possibilitar uma visualização representativa de objetos 
de estudo que não podem ser observados por possuírem dimensões muito grandes ou pequenas, ou por se manifestarem em tempos demasiadamente longos ou curtos. Em uma animação computacional, no entanto, não é possível modificar parâmetros ou condições, de forma que o usuário deste tipo de software ocupa um papel de expectador. Os modelos e ideias explicitados na animação são previamente estabelecidos pelo designer que a desenvolve.

- Softwares para visualizar e interagir com sistemas e fenômenos (simulações e laboratórios virtuais) - Com estes aplicativos, além de ser possível visualizar a representação de fenômenos e sistemas, assim como ocorre com as animações, é possível interagir com o aplicativo, alterando parâmetros e condições que regem a dinâmica da simulação. Este tipo de software possibilita, também, que experimentos que não possam ser realizados no contexto de sala de aula, seja pela complexidade, custo ou perigo, sejam realizados virtualmente. Ainda que haja certa liberdade na manipulação do software, por ser possível definir alguns dos parâmetros e condições do que é simulado; o que se simula obedece a modelos teóricos previamente definidos e programados pelo designer do aplicativo.

- Softwares de modelagem computacional - Este tipo de aplicativo possibilita elaborar e testar modelos teóricos que regem o comportamento de fenômenos e sistemas. Comumente, possui recursos gráficos limitados em comparação às simulações, mas por outro lado, permite a elaboração e teste de modelos de forma livre.

- Laboratório baseado em vídeos - Consiste em uma ferramenta que possibilita analisar o movimento em cenas de um vídeo, seja de uma situação filmada, ou de algo criado artificialmente. Neste tipo de aplicativo, é possível identificar um determinado elemento/objeto em uma cena, o qual possui um movimento em determinado tempo, de forma que o software consegue, a partir do movimento no vídeo, obter dados de posição, tempo, velocidade e aceleração, sendo possível traçar gráficos, como aqueles em função do tempo. 
- Sistema de instrumentação virtual (controle e coleta de dados) Sistemas de instrumentação virtual consistem em montagens experimentais em que sensores podem ser conectados a um computador com o uso de interfaces (circuitos eletrônicos) que convertem os sinais analógicos obtidos com os sensores, em sinais digitais que podem ser compreendidos por computadores. São sistemas ideias para práticas experimentais, facilitando a coleta de dados, e em alguns casos, permitindo o acompanhamento desta coleta de dados em "tempo real". Alguns destes sistemas possuem interfaces que permitem tratar e analisar os dados.

Em relação ao ensino semipresencial ou à distância, existem outras ferramentas computacionais de destaque que não são citadas pelas autoras. Tais ferramentas possuem como uma de suas principais funções, permitir a comunicação. Entre estas ferramentas destacamos três:

-Blog - é uma página pessoal, ou mantida em grupo, em que o responsável ou membros do grupo podem apresentar informações sobre diferentes temas e interagir com os outros, quando é habilitada a função de comentários às postagens. Em seu uso educacional, os alunos podem, por exemplo, apresentar sínteses de temas específicos, apresentar opiniões, ou mesmo compartilhar com os demais um determinado assunto (FOGAÇA, 2011; AVCI; ASKAR, 2012);

- Fórum - é uma ferramenta que permite o diálogo assíncrono entre todos os participantes de um grupo. Segue uma estrutura centrada em tópicos, pelos quais os participantes podem interagir entre si. Seu uso educacional é adequado para qualquer atividade que exija o diálogo entre os participantes de um grupo de alunos, ou mesmo para socializar os participantes de um curso à distância (CHENG et al., 2011; XIA; FIELDER; SIRAGUSA, 2013);

-Wiki - pode ser definido como uma coleção expansível de páginas web interligadas, em que a informação pode ser armazenada e modificada facilmente. É uma base de dados onde cada página é facilmente editada por qualquer usuário, bastando para isso utilizar um navegador de internet 
com suporte a formulários (LEUF; CUNNINGHAM, p.14, $2001^{8}$ apud CHOY e NG, 2007). Na educação, pode ser utilizada em trabalhos colaborativos, de forma assíncrona ou síncrona, em uma produção textual conjunta em que todos os participantes podem ser autores do que é produzido ( $\mathrm{AVCl}$; ASKAR, 2012).

Além destes, vale destacar também o ambiente virtual, o qual pode ser definido como uma ferramenta que abriga e permite o acesso às outras diferentes ferramentas. As ferramentas podem ser aquelas que são acessadas exclusivamente via navegador de Internet, como as de comunicação citadas acima, ou outras ferramentas demonstrativas e operativas, como é o caso das animações e das simulações computacionais.

Em nossa pesquisa, ainda que não envolva cursos à distância, os processos de ensino e aprendizagem investigados baseiam-se no uso de ambientes virtuais (dois ambientes, segundo o contexto de uso), em que as atividades previstas, textos, imagens estáticas e dinâmicas, e simulações estão todos reunidos e acessíveis. Assim, nesta pesquisa aproveitamos a capacidade integrativa e de organização dos ambientes virtuais.

\section{2- Uma visão crítica sobre o uso de TIC na educação}

Ao considerar as razões para a inserção das TIC na educação, principalmente as razões pedagógicas, cria-se uma expectativa positiva sobre o uso das TIC como algo que poderia levar a bons resultados de aprendizagem. No entanto, alguns autores já afirmam claramente que o simples uso de novos recursos tecnológicos na educação não conduz necessariamente a uma aprendizagem bem sucedida (WATSON, 2001; OSBORNE; HENNESSY, 2003; COX; WEBB, 2004; SMITH et al., 2005).

Em uma revisão da literatura sobre as barreiras para a integração das TIC em ambientes de ensino e aprendizagem, Bingimlas (2009), centrando-se no professor, destaca que entre os fatores que definem o insucesso no uso das TIC está o despreparo do professor em lidar com as TIC, a falta de um apoio técnicopedagógico, a falta de confiança e a resistência a mudanças. Atualmente diversos

\footnotetext{
${ }^{8}$ LEUF, B.; CUNNINGHAM, W. (2001). The wiki way: Quick collaboration on the web. Boston: Addison-Wesley.
} 
países promovem a inserção das TIC na educação, e o professor muitas vezes não sendo um nativo digital como seus alunos são, permanece na inércia de suas estratégias tradicionais, mesmo quando utiliza as TIC. Conforme afirmam Hennessy, Deaney e Ruthven (2003), muitas vezes os professores utilizam as TIC como suporte ou complemento para as suas aulas, apenas reproduzindo as práticas e estratégias já consolidadas na sala de aula comum, ao invés de usá-las como ferramentas que permitam o redesenho de conteúdos, objetivos e atividades.

Conforme afirma Webb (2005), um componente crucial no uso de TIC no processo de ensino e aprendizagem, além do professor, são as suas abordagens pedagógicas. Na mesma linha, Pintó, Couso e Hernández (2010) afirmam que a grande questão do sucesso ou insucesso no uso das TIC na educação está atrelada mais às condições de aprendizagem baseada no uso de TIC: deve-se escolher e avaliar recursos tecnológicos apropriados; e deve-se planejar, estruturar e sequenciar um conjunto de atividades baseadas no uso de TIC. Ou seja, as TIC devem receber uma atenção adequada no planejamento das atividades, ocupando algum papel, e não somente atuar como ferramentas pontuais e dispensáveis (por exemplo, para trazer uma ilustração a mais de um objeto de estudo, ou para apresentar algo a mais como curiosidade).

Considerando isso, podemos afirmar que até mesmo a motivação para a aprendizagem que as TIC podem proporcionar, para que se mantenha, depende fortemente da forma como estas são utilizadas. Uma visão mais crítica e analítica pode revelar que o que eventualmente provoca uma motivação é o fato de estas tecnologias serem uma novidade, e não unicamente o fato delas permitirem facilidades, as quais podem não estar sendo exploradas apropriadamente. Assim, já que o constante uso tirará das TIC o caráter de novidade, para que continue a haver motivação, as estratégias empregadas pelos professores também necessitam ser inovadoras e diversificadas, por exemplo, de forma a permitir uma participação ativa e interativa dos alunos, e de forma a explorar as particularidades do conteúdo a ser aprendido.

É importante frisar que não negamos as múltiplas novas possibilidades que as TIC permitem. Como já comentamos, as TIC podem facilitar a visualização e percepção de fenômenos e conceitos difíceis ou abstratos. O que afirmamos aqui, em consonância com outros autores, é que o uso das TIC, por si só, não garante 
sucessos educacionais. Conforme afirma Watson (2001), a pedagogia deveria antecipar a tecnologia. Neste sentido, assumimos que o planejamento da situação de ensino, que inclui a definição de estratégias adequadas e que considera as características próprias do conteúdo que se pretende ensinar, é o que poderá levar a sucessos com o uso das TIC. Assim, em nossa pesquisa procuramos identificar em situações de uso de TIC específicas, as simulações computacionais, como obstáculos epistemológicos e didático-pedagógicos surgem e são tratados. 


\section{PARTE II - FUNDAMENTAÇÃO TEÓRICA}

$\mathrm{Na}$ pesquisa aqui descrita sobre o uso de simulações computacionais no ensino e aprendizagem de tópicos de FMC, assumimos como nossa fundamentação teórica algumas ideias provenientes da corrente de estudo em ensino de ciências que relaciona as noções de analogia e metáfora com a ideia de modelos, e assim, dedicamos o capítulo 4 a expô-las. Além disso, como o nosso interesse de pesquisa concentra-se no papel dos obstáculos que podem emergir em situações de uso das simulações computacionais, discutimos no capítulo 5 as noções de obstáculo epistemológico e obstáculo didático-pedagógico, respectivamente, desde a perspectiva de Bachelard e Brousseau. Já o capítulo 6 é dedicado a melhor integrar as ideias que elencamos como nosso marco teórico nos capítulos 4 e 5 , relacionando-as com a delimitação da pesquisa.

\section{4- ANALOGIAS, METÁFORAS E MODELOS}

Os termos analogia e modelo contam com vários significados tanto na literatura acadêmica quanto no uso coloquial. Assim, antes de expor qual a relevância destas noções em nosso estudo, dedicaremos os subcapítulos 4.1 e 4.2 a definir cada um destes termos segundo o significado que assumem em nossa pesquisa e buscaremos associá-los ao conceito de aprendizagem. Dedicaremos ainda o subcapítulos 4.3 a expor algumas abordagens sobre analogias e modelos presentes na literatura, entre as quais buscaremos situar a nossa pesquisa.

\section{1- Diferenciação entre analogias e metáforas}

Os termos analogia e metáfora são utilizados muitas vezes de forma indiscriminada, tanto no cotidiano como na literatura científica. Em alguns casos, utilizam-se ambos os termos assumindo um mesmo significado. Duarte (2005), em um estudo sobre o uso das analogias na educação em ciências, afirma que elas são utilizadas não somente de forma indistinta em relação à ideia de metáfora, mas também em relação a outros termos como "modelo", "símile" e "exemplo". Embora no uso cotidiano esta mistura de significados seja aceitável pelas nuances que separam os termos, no uso acadêmico é necessário estabelecer fronteiras, mesmo que provisórias e parciais. 
No presente estudo, adotamos uma definição divergente e específica para cada um dos termos analogia, metáfora e modelos, sendo que este último se desdobra ainda em vários tipos, os quais são detalhados mais à frente.

Em concordância com Duit (1991), definimos analogia como uma comparação explícita entre estruturas de dois domínios diferentes, em que se identifica a semelhança entre parte dos dois domínios. Como representado na Figura 1, a seguir, um domínio D1 por analogia pode ter algumas de suas características ou propriedades comparadas a um domínio D2, reconhecendo assim algum nível de similaridade entre os dois domínios.

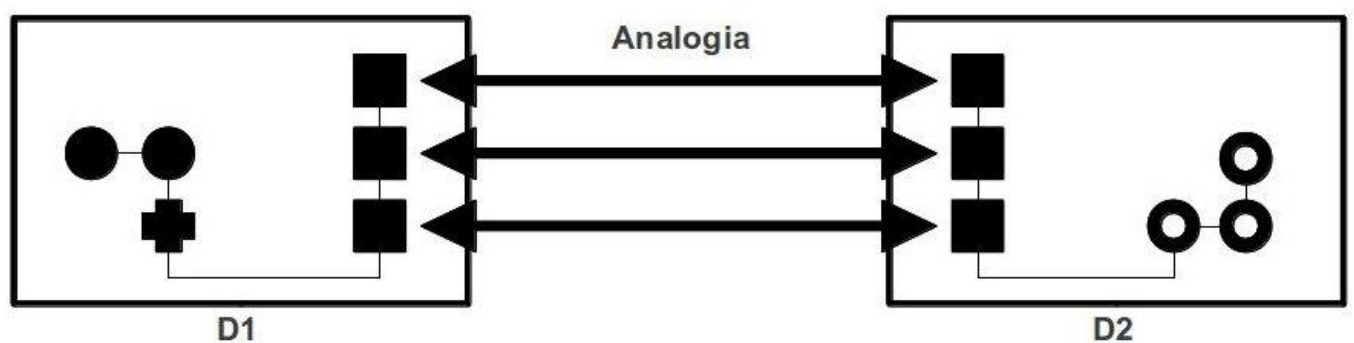

Figura 1. Representação do significado do termo analogia. Adaptado de Duit (1991).

Utges (1999) afirma que o raciocínio analógico que é empregado em qualquer comparação por analogias consiste em:

"[...] utilizar instâncias nas quais domínios menos familiares se tornam mais compreensíveis ao se fazer apelo à semelhança com um domínio mais familiar, estabelecendo uma ponte entre o menos conhecido e o mais conhecido" (UTGES, 1999, p. 37)

Um exemplo de uso de analogia no âmbito científico é a comparação feita por Rutherford entre o modelo atômico e um sistema planetário. Nesta comparação, o movimento dos planetas em torno do Sol seria análogo ao movimento dos elétrons em torno do núcleo atômico, sendo este movimento inclusive regido por equações matemáticas semelhantes. Os domínios são diferentes, mas há uma semelhança entre estes que é explorada na analogia.

Em relação à metáfora, assim como Duit (1991), a definimos como uma comparação implícita em que não ficam em destaque as características ou qualidades relacionais que coincidem ou não em dois domínios. Se entendida de forma literal, a metáfora torna-se falsa, e até mesmo absurda. Muito empregada na poesia, a metáfora possui um aspecto de surpresa, sendo que a base de comparação deve ser revelada ou mesmo criada pelo destinatário da metáfora 
(leitor, ouvinte, expectador). Uma afirmação como "o jogador foi um leão em campo" é um exemplo de metáfora, pois a característica comparada entre o jogador e o leão não é exposta na expressão, a qual se assumida de forma literal torna-se absurda. Ao interpretar a frase, o destinatário poderá entender que assim como o leão apresenta bravura e empenho face aos seus adversários, o jogador também atuou com bravura e empenho.

Outro exemplo de metáfora, porém no contexto da Física, seria uma afirmativa como "um condutor elétrico é uma ponte para carros velozes". Sem dúvida, a interpretação literal seria absurda, já que não vemos condutores elétricos sendo utilizados como pontes para carros, elétrons não são carros velozes e nem mesmo se movimentam com motores, possuem pneus, motorista, etc. Uma interpretação não literal da metáfora, e sob a ótica da Física, poderia ser a de que assim como os carros velozes passam rapidamente de uma margem a outra de um rio por uma ponte, os elétrons passam rapidamente de uma região com potencial elétrico negativo para uma região de potencial elétrico positivo por um condutor elétrico. A comparação aqui focalizada (o papel da ponte em possibilitar a passagem de algo) não está explícita no enunciado. A Figura 2 que elaboramos e é apresentada a seguir, é uma representação com o uso de conjuntos da interpretação da metáfora do condutor elétrico e da ponte.

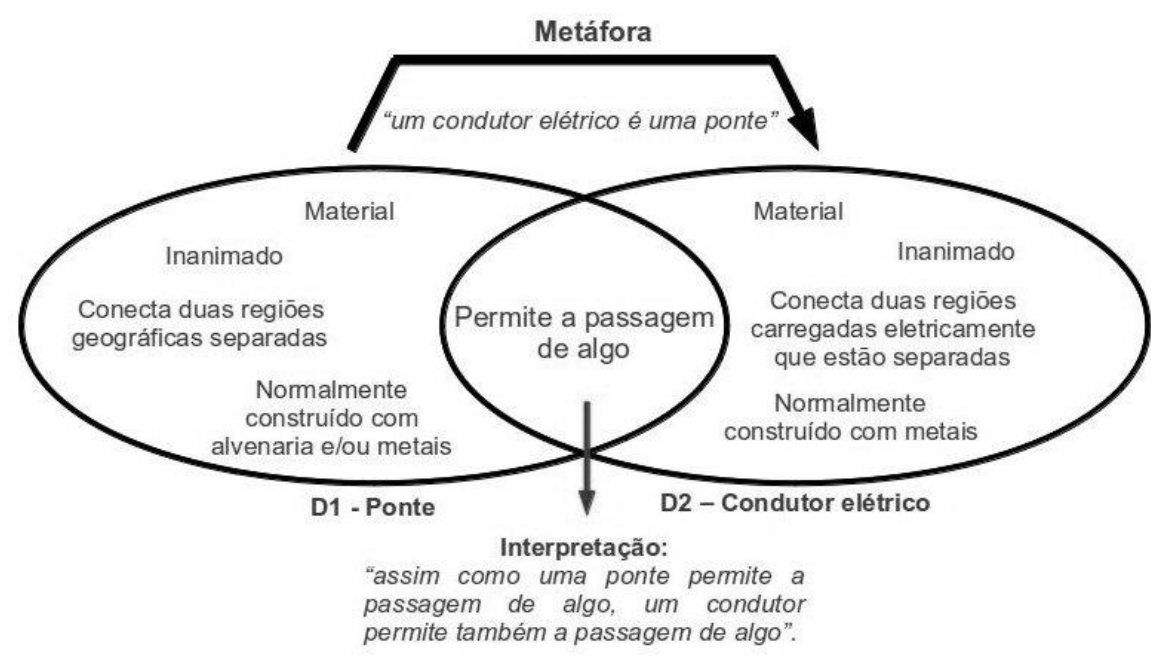

Figura 2. Representação da interpretação de uma metáfora.

Como se observa na representação, a afirmativa é uma metáfora envolvendo os domínios D1 e D2. Para que se interprete a metáfora, levantam-se 
algumas características de ambos os domínios, buscando entre os elementos coincidentes ou próximos, uma possível interpretação.

De certa forma, o que diferencia uma analogia de uma metáfora é a "visibilidade" do que se está comparando. Enquanto que em uma analogia há uma exposição clara do que é semelhante, na metáfora tal semelhança está escondida em elementos não enunciados, e é na interpretação da metáfora que se tenta identificar a semelhança. Assim, para a metáfora do condutor elétrico e da ponte, passaríamos a ter não mais uma metáfora, e sim uma analogia, se modificássemos o enunciado para "um condutor elétrico é como uma ponte que permite que elétrons passem por ele, assim como os carros passam por uma ponte".

Ainda que reconheçamos que o uso de metáforas esteja presente em situações ensino e aprendizagem, pela natureza do nosso estudo daremos mais atenção ao papel das relações de analogia no processo de aprendizagem. Mais à frente neste texto descreveremos o uso das imagens digitais, animações e simulações computacionais em termos de relações de analogias, as quais poderão ser úteis para a ocorrência de aprendizagens.

\section{2- Modelos}

O termo modelo, assim como analogias e metáforas, é utilizado para designar diferentes coisas, em diferentes áreas do conhecimento e, portanto, é um termo polissêmico. Em alguns casos, modelos, analogias e metáforas são considerados como sinônimos, e em outros casos, assumem significados totalmente diferentes. Dentro de um mesmo campo do conhecimento é comum encontrarmos variados subtermos relacionados aos modelos. Por exemplo, na literatura em ensino de ciências encontramos tipologias que incluem modelos mentais, modelos científicos, modelos matemáticos, modelos teóricos, modelos analógicos, modelos conceituais, modelos consensuais, modelos pedagógicos, modelos escolares, entre outros. Pode-se dizer que, apesar da polissemia do termo modelo, para muitos deles há um ponto de interseção: normalmente os modelos designam diferentes representações de algum conhecimento estruturado.

O filósofo da ciência Max Black (1962), ao analisar o papel dos modelos e das metáforas na ciência, foi talvez um dos primeiros a propor uma tipologia de modelos. Sua tipologia, em essência, se baseava no grau de abstração dos 
modelos, na qual em um grau de abstração do menor para um maior existiriam os modelos: empírico, analógico, matemático e teórico. Não adotamos esta classificação em nosso trabalho, e por isso não a detalharemos. No entanto, o trabalho de Black merece ser referenciado pela sua importância no campo de estudo do pensamento metafórico e analógico praticado na ciência, e por ainda influenciar diversas pesquisas no campo de modelos e analogias.

$\mathrm{Na}$ literatura acadêmica em ensino de ciências, o estudo dos modelos é comumente associado ao estudo das analogias e metáforas (OLIVA et al., 2001). Em nosso estudo, para compreendermos a noção de modelos partimos do trabalho de Duit (1991), o mesmo que tomamos para definir as analogias e metáforas. Nesse trabalho, a noção de modelo é apresentada dentro de um esquema que integra a noção de analogia. O trabalho de Duit tem sido utilizado há alguns anos, em diversas investigações que abordam as noções de analogia e metáfora e as relações entre o raciocínio analógico e a formação de modelos (DUIT; GLYNN, 1996; GRECA; MOREIRA, 2000; DUIT et al., 2001; DUARTE; 2005; GONZÁLEZ, 2005; RAVIOLO, 2007).

Ao analisar a relação entre modelos e analogias, Duit (1991) define dois domínios: i) um, o alvo (target) que é o objeto de estudo, material ou não, o qual se deseja obter informações para melhor conhecê-lo; ii) e outro, o análogo (analog), que é o domínio que se utiliza como referente para conhecer, por analogia, o alvo. Para Duit, um modelo surge pela comparação entre os dois domínios, ou seja, o modelo é o resultado da analogia, em que os nexos semelhantes na relação analógica comporão um novo domínio, o modelo, enquanto os que não são semelhantes são desconsiderados. A Figura 3, que se segue, representa os domínios envolvidos na analogia. O domínio D1 é definido como o análogo, e o domínio D2 como o alvo, e o domínio Dm é o modelo que surge a partir da relação analógica entre os domínios D1 e D2. 


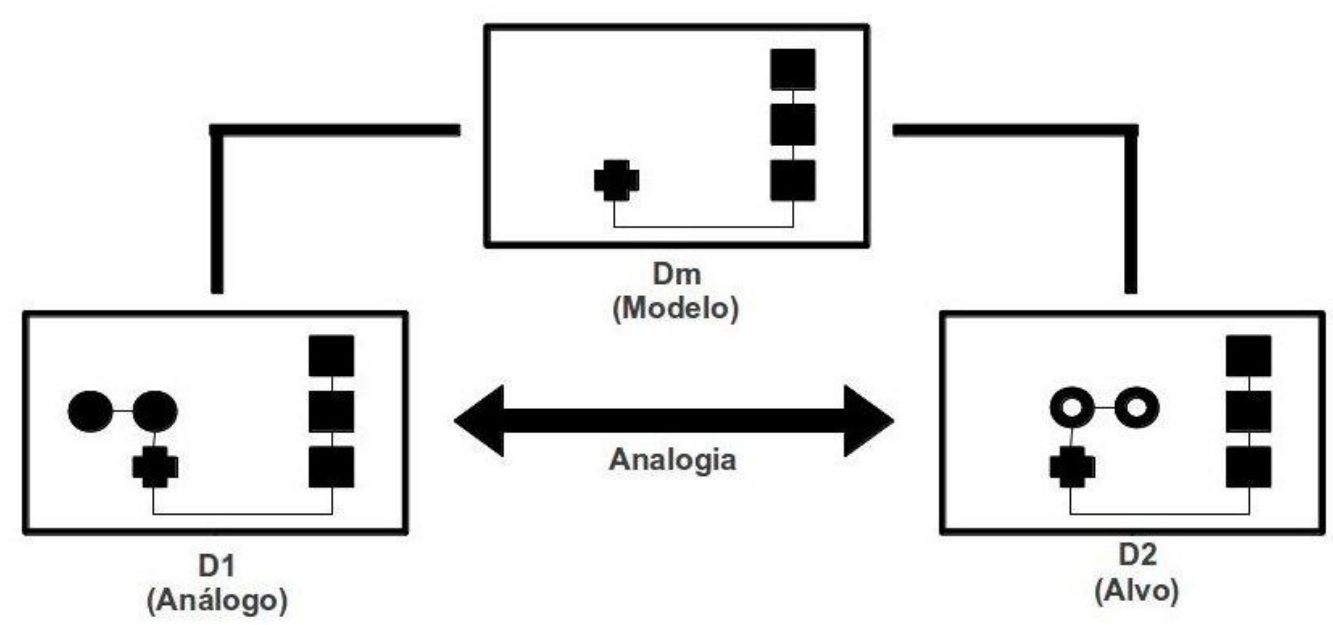

Figura 3. Representação do significado para os termos analogia e modelo. Adaptado de Duit (1991).

Para Duit, o modelo é uma representação de parte do domínio alvo, que como vemos no esquema apresentado na Figura 3, consiste em uma estrutura formada a partir da interseção dos dois domínios, o análogo e o alvo. Situam-se no domínio análogo qualquer representação utilizada para estudar, por analogia, um conhecimento alvo. No âmbito escolar, este conhecimento alvo é previamente didatizado compondo parte do conjunto de saberes a serem ensinados.

A este modelo criado por analogia, poderíamos chamar de modelo analógico. Em um processo de aprendizagem, um modelo analógico pode ser usado pelo professor com o intuito de se promover, nos alunos, a construção de um modelo mental que se aproxime do objeto de estudo, o alvo presente no domínio D2 do esquema de Duit.

Cabe enfatizar que o modelo analógico é concebido, muitas vezes de forma dinâmica na situação de aula, na intenção didática do professor. Ou seja, o professor ao elencar uma representação de um determinado alvo de ensino, o faz esperando que os alunos percebam o modelo analógico que é resultado da analogia. Logicamente, como outros elementos estão presentes no domínio alvo e no domínio análogo, dependendo de como são exploradas as analogias, os alunos poderão obter/perceber um modelo analógico inesperado, que por sua vez poderá contribuir para a construção de um modelo mental incorreto do que se pretendia ensinar (o modelo conceitual alvo). 
Para melhor aprofundar essa relação dedicamos o item 4.2.1, a seguir, a definir a noção e o papel dos modelos mentais e dos modelos conceituais, e suas relações com a aprendizagem.

\subsection{1 - Modelos mentais, modelos conceituais e a aprendizagem}

Segundo Borges (1997), no âmbito da psicologia cognitiva expressões como modelos mentais, uma categoria específica de modelos, já vêm sendo utilizados desde, pelo menos, os anos 60 do século $\mathrm{XX}$, sem que houvesse, contudo, uma definição explícita para tal termo. Ainda segundo o autor, é a partir dos anos 80 do século XX que tal termo começa a se disseminar:

O conceito de modelo mental se disseminou a partir da publicação de dois
livros, ambos com o título "Mental Models", publicados em 1983. O primeiro
deles, editado por Gentner e Stevens (1983) é uma coleção de
contribuições a um seminário sobre o assunto. Nele várias visões do
conceito são apresentadas de maneira mais ou menos implícita. O segundo
livro (Johnson-Laird, 1983) é um trabalho em que o autor procura explicar o
raciocínio dedutivo e a compreensão de texto. A partir daí, o conceito de
modelo mental começou a ser usado ao lado de outros como "frame',
"schema" e "script" e como resultado, a terminologia empregada nas
diferentes áreas não é uniforme (BORGES, 1997, p.208) ${ }^{9}$.

Greca e Moreira (1998, 2000), ao discutir os modelos mentais e seu papel no processo de ensino e aprendizagem, afirmam que os alunos constroem representações internas, os chamados modelos mentais, as quais são baseadas em seu conhecimento prévio (ideias ou concepções preexistentes na estrutura cognitiva) e experiências passadas. Segundo os autores, os modelos mentais são úteis ou funcionais permitindo aos alunos a explicação de fenômenos ou eventos, e a fazer previsões. Pode-se dizer que um modelo mental é uma representação de alguma realidade material ou abstrata que se forma na mente de alguém, considerando o que este alguém já conhece e a partir da observação direta ou indireta (por analogia) do objeto de estudo que faz parte de uma realidade.

Como o conhecimento prévio interfere na formação de um determinado modelo mental, não é difícil perceber que o modelo mental é individual e específico para cada indivíduo, possuindo assim para ele um maior sentido. Contudo, como a realidade é de certa forma compartilhada socialmente, há a necessidade de uma

\footnotetext{
${ }^{9}$ Referências citadas pelo autor: GENTNER, D.; STEVENS, A. L. Mental Models. Hillsdale, NJ: Lawrence Erlbaum, 1983.

JOHNSON-LAIRD, P. Mental Models. Towards a Cognitive Science of Language, Inference, and Consciousness . Harvard University Press. Cambridge, 1983. 513 p.
} 
proximidade entre modelos mentais de indivíduos diferentes que interpretam uma mesma realidade.

Ao caracterizar os modelos mentais, Greca e Moreira (1998) afirmam:

[...] os modelos mentais são incompletos; instáveis (as pessoas esquecem detalhes de seus modelos ou os descartam); não têm fronteira bem definidas; são não-científicos (refletem as crenças das pessoas sobre o sistema representado); são parcimoniosos (frequentemente, as pessoas optam por operações físicas adicionais, por gastar mais energia, em troca de uma melhor complexidade mental). O único compromisso dos modelos mentais é a sua funcionalidade para o sujeito. A principal função de um modelo mental é a de permitir ao seu construtor explicar e fazer previsões sobre o sistema físico representado. (GRECA; MOREIRA, 1998, p. 109, tradução nossa).

Assim, pode-se dizer que um modelo mental, ainda que seja próprio de um sujeito e não possua um formato muito estável e preciso, é um importante artifício para que o indivíduo interprete o mundo. É uma unidade básica do pensamento que permite a imaginação do objeto de estudo mesmo que este não esteja presente.

Um modelo mental pode ser de alguma forma externalizado pelo indivíduo, como uma forma mais ou menos elaborada, e mais ou menos próxima da respresentação mental. Segundo Greca e Moreira (1998, 2000), esta representação externa do modelo mental, quando criada por determinados especialistas (pesquisadores, professores, engenheiros, entre outros) e que facilita a compreensão ou o ensino de sistemas ou estados das coisas no mundo, se alcançar um consenso na comunidade de especialistas, pode se tornar um modelo conceitual.

Enquanto no âmbito da ciência, um modelo conceitual se apresenta como uma representação precisa, completa e consistente com o conhecimento cientificamente compartido; na educação se apresenta também como preciso, completo e consistente, não diretamente com um conhecimento cientificamente compartido, mas sim com um conhecimento científico previamente didatizado, compartido nos livros didáticos, na prática docente, entre outros.

Clement (2000), ao discutir a formação de modelos mentais em um processo de aprendizagem, apresenta a aprendizagem como uma construção de modelos mentais relacionados a um modelo conceitual alvo, o qual, por sua vez, é resultado de um processo de didatização do modelo consensual dos especialistas. Ele apresenta um esquema representativo do processo de aprendizagem, semelhante ao apresentado na Figura 4, a seguir: 


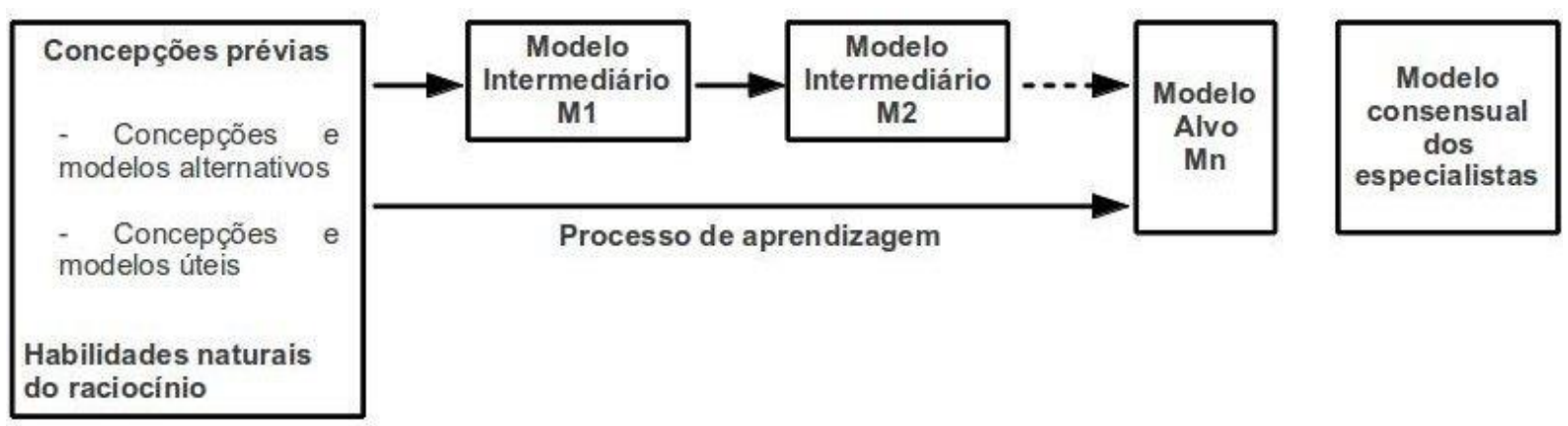

Figura 4. Representação do processo de aprendizagem e as noções de modelo conceitual e modelos mentais. Adaptado de Clement (2000).

Segundo esta representação, a aprendizagem consiste em um processo pelo qual as concepções prévias dos alunos são aperfeiçoadas, e em que modelos mentais intermediários (M1, M2, ... Mn-1. ) são construídos, e ao serem revistos se aproximam de um modelo conceitual alvo (Mn), que é o conhecimento que se espera que seja aprendido.

Em nossa pesquisa, adotamos esta concepção de aprendizagem proposta por Clement (2000). No entanto, nos desprendendo de uma visão cognitivista exclusiva sobre o que é e como ocorre a aprendizagem, e buscamos entender o papel do ensino e das ferramentas didáticas e pedagógicas ${ }^{10}$ no desenvolvimento da aprendizagem. Assim, sugerimos uma adequação ${ }^{11}$ no esquema proposto por Clement, na qual incluímos a dimensão do ensino. Esta adequação é apresentada na Figura 5, a seguir:

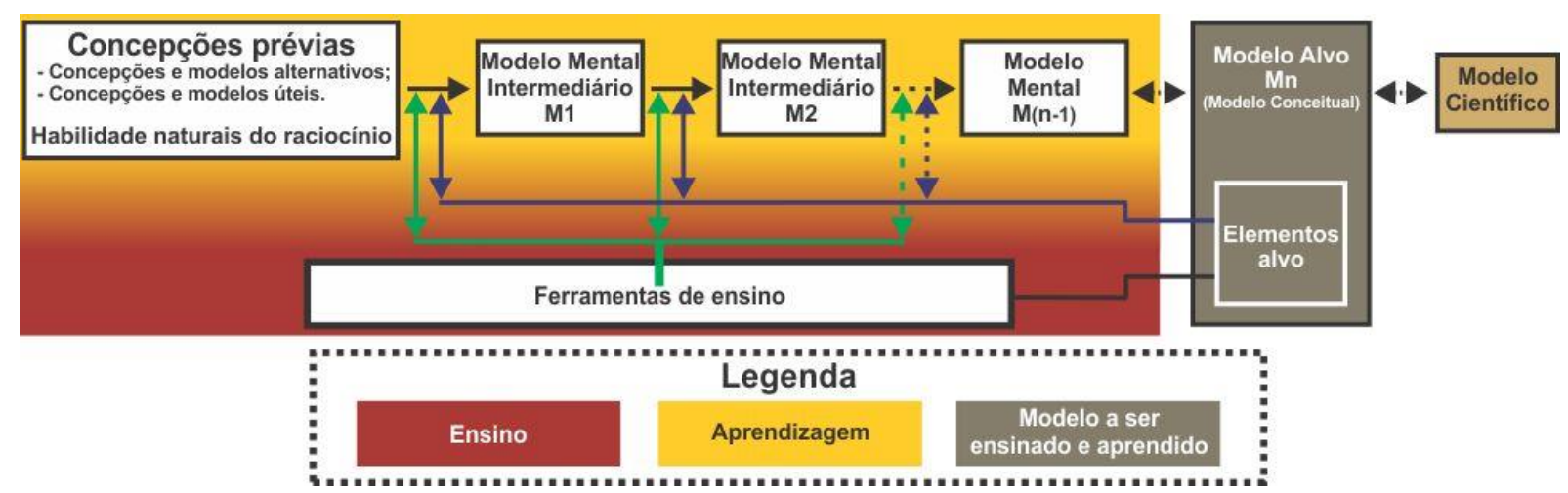

Figura 5. Representação do processo de ensino-aprendizagem elaborado a partir do esquema proposto por Clement (2000).

\footnotetext{
${ }^{10}$ As ferramentas didáticas e pedagógicas, que indicamos na Figura 5 como "Ferramentas de ensino", são as estratégias e recursos utilizados pelo professor no processo de ensino-aprendizagem.

${ }^{11} \mathrm{Na}$ adequação também inserimos o "modelo científico" em lugar do "modelo consensual dos especialistas". Conforme discutiremos no item 4.2.2, um modelo científico é uma forma de modelo consensual dos especialistas (cientistas) e, portanto, não há prejuízos com esta mudança.
} 
No esquema apresentado na Figura 5, o processo de aprendizagem é representado pela evolução dos modelos mentais se aproximando do modelo alvo $\left(\mathrm{M}_{(\mathrm{n}-1)}\right)$. O resultado de aprendizagem esperado é aquele em que o Modelo Mental $\mathrm{M}_{(\mathrm{n}-1)}$ seja próximo ao Modelo Alvo $\mathrm{Mn}$. Como nesta representação é incluída a dimensão do ensino ao processo de aprendizagem, podemos redefini-lo como processo de ensino-aprendizagem. O professor, em seu planejamento didático e de acordo com as necessidades que surgem durante a situação de aula, elenca diferentes ferramentas de ensino, ou seja, os diferentes meios que poderão auxiliar os alunos para que construam seus modelos mentais.

No processo dinâmico em sala de aula, professor e alunos recorrem aos elementos alvo que compõem o Modelo Conceitual, diretamente (setas azuis) ou indiretamente mediante 0 uso das ferramentas de ensino (setas verdes). Considerando que os alunos não são sujeitos passivos neste processo, as setas são sempre duplas, de forma que tanto o professor como alunos trafegam no acesso às ferramentas de ensino e ao modelo conceitual. As setas duplas também representam os diálogos que se dão na situação de aula. Pela complexidade dessas interações, não há uma clara separação entre a dimensão do ensino e da aprendizagem, o que é representado no esquema pela variação gradiente de cores que mistura ambas as dimensões.

Vale destacar que o professor não acessa diretamente os modelos mentais dos alunos para caracterizá-los, ou mesmo para auxiliar em sua formação. Ele utiliza ferramentas de ensino com a intenção de gerar nos alunos determinados modelos mentais. Somente mediante os modelos expressos dos alunos é que o professor poderá inferir sobre os modelos mentais destes. No esquema, não representamos claramente os modelos expressos dos alunos, porém eles estão presentes em meio às interações entre alunos e professor, representadas pelas setas duplas (azuis e verdes).

As ferramentas de ensino que poderão ser elencadas pelo professor podem ser variadas, e escolhidas especificamente para cada etapa do processo de evolução dos modelos mentais. Ou seja, o professor poderá escolher ferramentas específicas para cada modelo parcial que ele espera que os alunos construam.

Considerando o uso de análogos, podemos ainda adaptar o esquema anterior (Figura 5), de forma a incluir o processo de ensino norteado pelo modelo 
conceitual e amparado por relações de analogia, considerando o descrito por Duit (1991) e já apresentado neste texto. Conforme pode ser observado na Figura 6, a seguir, ao se utilizar analogias os vários análogos são representados em um conjunto (D1s), que na comparação por analogias com o objeto de estudo geram modelos analógicos $\left(\mathrm{Dm}_{\mathrm{s}}\right)$, assim como descrito por Duit. Os modelos analógicos $\left(\mathrm{Dm}_{\mathrm{s}}\right)$ fazem parte da intenção didática do professor, ou seja, são os resultados pretendidos com o uso da analogia que ele espera que os alunos reconheçam. A recorrência ao modelo alvo e à analogia é feita tanta pelo professor como pelo aluno, e assim, mantém-se as setas duplas do esquema anterior, as quais continuam a também representar os diálogos que ocorrem em sala de aula. A este todo representado na Figura 6 podemos chamar de processo de ensinoaprendizagem mediado por analogias. Neste processo, uma ou mais analogias podem ser utilizadas para permitir que os modelos mentais dos alunos se aproximem do modelo alvo que se deseja que seja compreendido.

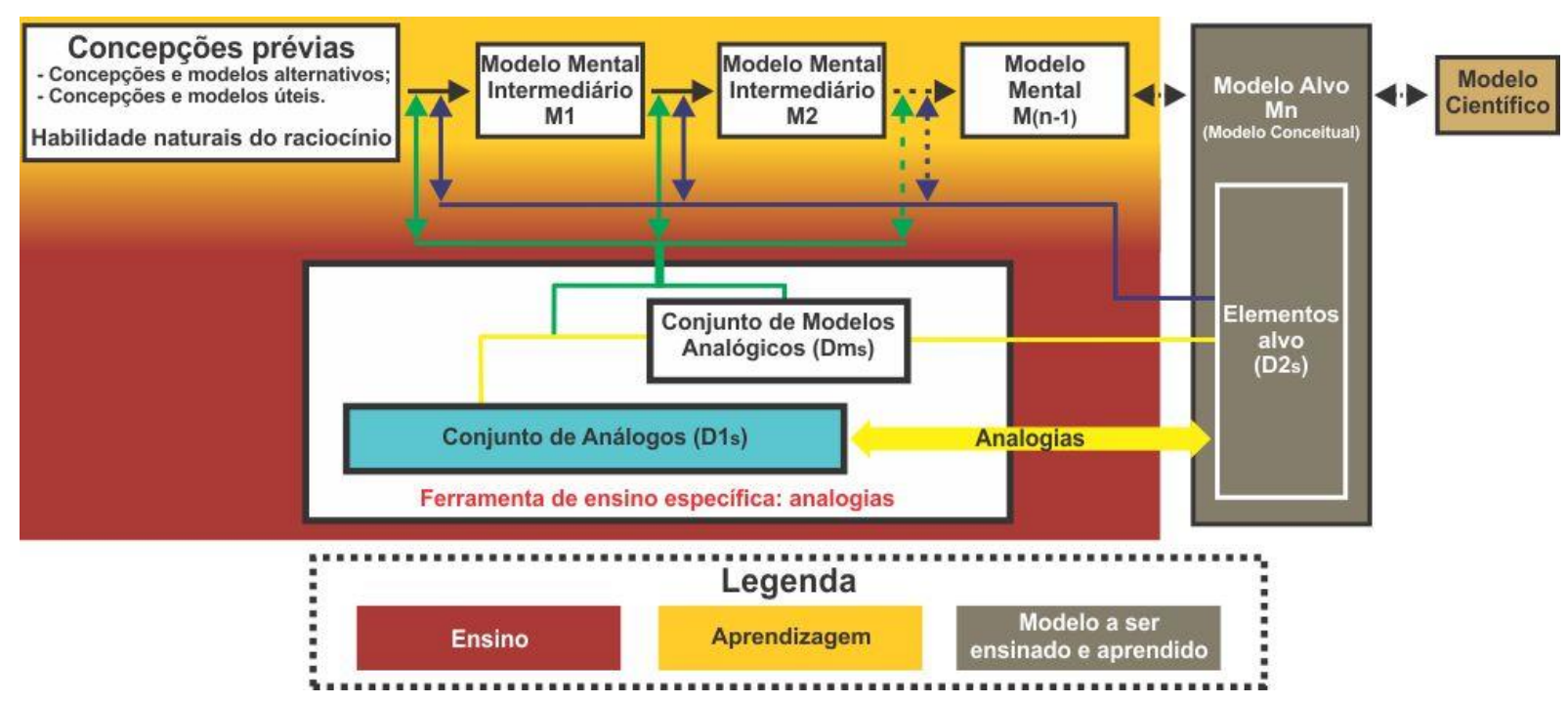

Figura 6. Representação do processo de ensino-aprendizagem mediado por analogias, baseando-se nos esquemas propostos por Duit (1991) e na versão já adaptada do esquema de Clement (2000).

\subsection{2- Tipologias de modelos}

Não pretendemos nesta pesquisa investigar e classificar os variados tipos de modelos em ciência e ensino de ciências. Nosso olhar sobre os modelos está focado no intermédio entre um modelo conceitual apresentado no contexto escolar e a construção de modelos mentais. No nosso olhar, visamos identificar os obstáculos que impossibilitam uma proximidade entre um modelo mental criado e o modelo conceitual alvo apresentado por professores a partir das relações analógicas que se 
estabelecem com o uso de simulações computacionais, as quais atuam como um domínio análogo. Ou seja, nos interessa identificar em um processo de ensinoaprendizagem a emersão de obstáculos próprios do pensamento ou obstáculos relacionados ao ensino, que atuam prejudicando o desenvolvimento de um modelo mental que seja próximo ao modelo conceitual. Além disso, nos interessa identificar as formas como tais obstáculos podem ser superados. Entretanto, para melhor nos situarmos entre as variadas definições existentes, apresentamos neste item 4.2.2 uma tipologia de modelos que consideramos compatível com o nosso estudo.

Conforme já comentamos, um modelo mental se forma na mente de alguém, a partir da interpretação de um determinado alvo, seja de forma mais direta ou mais indireta, como no uso de analogias. Um modelo mental pode ser externalizado, ao que alguns autores (GILBERT E BOUTER ${ }^{12}$, 1995 apud COLL; FRANCE; TAYLOR, 2005) chamam esta forma externalizada de modelo expresso. Segundo estes autores, o modelo mental pode ser expresso através da ação, da fala, da escrita ou outra forma simbólica, originando assim os modelos expressos. O modelo expresso não coincide integralmente com o modelo mental que o originou, entre outras coisas, pela dificuldade estrutural, linguística ou representativa em expor o que se pensa. Assim, ainda que seja um modelo diretamente relacionado ao modelo mental, o modelo expresso é mais delimitado que o modelo mental que o originou.

Vale destacar que não estamos considerando como modelos expressos representações únicas e desconectadas de uma estrutura. Para nós, um modelo expresso é uma representação acompanhada de um conjunto de ideias, que necessariamente também são externalizadas. Assim, não consideraríamos como modelo uma única representação, como um desenho de um objeto; mas sendo este desenho parte de uma estrutura representativa composta por um conjunto de outros elementos também externalizados, este conjunto definimos como um modelo. Neste sentido, ainda que utilizemos a mesma terminologia de Gilbert e Bouter (1995 apud COLL; FRANCE; TAYLOR, 2005), nos diferenciamos por possuirmos um entendimento mais restrito do que seria um modelo expresso.

\footnotetext{
${ }^{12}$ GILBERT, J. K.; BOULTER, C. J. Stretching models too far. In: Annual Meeting of the American
} Educational Research Association. San Francisco, 22-26 abril, 1995 
Por exemplo, um desenho que representa um objeto de estudo, constitui-se parte de um modelo expresso. O modelo expresso seria composto por, além do desenho, um conjunto que inclui as explicações dadas sobre o que o desenho representa. Destaca-se ainda que, como os modelos mentais não são acessíveis diretamente nas situações de sala de aula, são os modelos expressos que fornecerão indícios sobre o desenvolvimento da aprendizagem e que permitirão o reconhecimento, por parte do professor, de um redimensionamento necessário do ensino. Logo, para fins de pesquisa, são nos modelos expressos que se buscam alguns dos indícios de aprendizagem, se buscam os elementos que atuem como obstáculos e, em contraste com a atuação do professor, que permitem verificar a superação de alguns tipos de obstáculos.

Os modelos expressos podem surgir e atuar não somente em processos de ensino-aprendizagem, como o que ocorre quando os alunos externalizam seu modelos de pensamento, mas podem surgir na própria ciência, a qual se ocupa também de construir e expor modelos. Desde uma visão da ciência como sendo um conhecimento aproximado, a ciência é entendida como uma atividade de elaboração, teste e contínuo aperfeiçoamento de modelos. Um cientista, ao apresentar um determinado modelo, que também podemos chamar de um modelo expresso, pode apresentar na forma de hipótese, que será validada ou não pelos seus pares. Esta forma de modelo expresso estruturado e sujeito a testes podemos chamar de modelo teórico. Um modelo teórico baseado em relações mais abstratas e de natureza matemática, isto é, em que há um formalismo matemático estruturado, definimos como um modelo matemático.

Para Gilbert e Bouter (1995 apud COLL; FRANCE; TAYLOR, 2005), no âmbito de uma comunidade científica, um modelo expresso que obtém aceitação social na comunidade, após ser submetido a testes pelos cientistas profissionais, torna-se um modelo consensual. Segundo estes autores, um modelo consensual que está em uso em uma época atual pode ser definido como um modelo científico; enquanto outro modelo já superado, mas que foi um modelo consensual em um determinado contexto histórico, pode ser chamado de modelo histórico. Por exemplo, o modelo atômico de Thomson, que em determinado período da história da ciência era aceito de forma consensual como suficiente para explicar a estrutura do 
átomo, mas que após foi superado e reconhecido como inadequado, seria um modelo histórico.

No âmbito da ciência, o modelo consensual pode também ser chamado de modelo conceitual, uma vez que integra um conjunto de ideias que definem conceitualmente o conhecimento envolvido. Já no contexto da educação, esta relação entre um modelo consensual da ciência e um modelo conceitual não é tão direta. Um modelo consensual da ciência passa por um processo de didatização, em que vários agentes intervêm até chegar ao modelo consensual didatizado. Desta forma, quando falamos em um modelo conceitual no âmbito da educação, não nos referimos diretamente ao modelo consensual da ciência, mas sim a um modelo consensual resultado de um complexo processo de transformações dos saberes da ciência $^{13}$ adequando-os de forma que possam ser ensinados. Logo, um modelo consensual é dito assim em relação ao âmbito em que se torna um consenso e, portanto, um modelo conceitual que se estabelece no âmbito da ciência não é necessariamente um modelo conceitual que se estabelece no âmbito da educação, ainda que possam existir relações significativas entre os dois modelos conceituais. Assim, utilizaremos uma terminologia diferente para nos referir ao modelo conceitual que se dá em cada âmbito. Ao modelo conceitual da ciência chamaremos de modelo científico, enquanto que ao modelo conceitual didatizado continuaremos a chamar neste trabalho de modelo conceitual. Na Figura 5, que apresentamos anteriormente, já incluímos esta consideração ao adaptarmos o esquema proposto por Clement.

Como de certa forma um modelo histórico foi um modelo científico de uma determinada época e como a superação de um modelo não impede o seu uso prático na ciência e na escola (por exemplo, a mecânica newtoniana foi superada, mas ainda continua a ser utilizada), nesta pesquisa definimos ainda o modelo histórico como um tipo específico de modelo científico. Com esta consideração, além de simplificar a tipologia, a aproximamos do contexto do ensino de ciências em que um modelo histórico é comumente apresentado como possuindo uma validade menos delimitada do que na ciência.

\footnotetext{
${ }^{13}$ Em seu livro "La Transposition Didactique", o educador e pesquisador francês Yves Chevallard, ainda que utilize uma terminologia diferente, descreve o processo em que um modelo consensual da ciência (saber sábio), se transforma em um modelo consensual próprio do contexto escolar (saber a ensinar), que é um saber possível de ser ensinado na escola.
} 
Considerando as características desta pesquisa, incluímos ainda nesta tipologia o modelo analógico que definimos anteriormente. Conforme já comentamos, um modelo analógico é o resultado de uma relação de analogia. professor, ao utilizar um análogo para apresentar um determinado conhecimento alvo, tem em mente um modelo analógico que ele espera que seja reconhecido. Além disso, o próprio aluno ao analisar a relação analógica, chegará a um modelo analógico que lhe será útil na formação de seu modelo mental.

Desta descrição tipológica que adotamos e apresentamos neste subcapítulo, é possível perceber que os chamados "modelos mentais" estão presentes não somente em um processo de aprendizagem, mas também na própria construção de um modelo científico. Uma vez que a ciência é composta de um corpo social, os indivíduos que a compõem estão, a todo o momento em que atuam cientificamente, empregando os seus modelos mentais que são elaborados e desenvolvidos ao longo de sua formação acadêmica e em seu trabalho profissional. O cientista, em seu fazer ciência, pode ainda expor correspondentes de seus modelos mentais na forma de modelos teóricos, que poderão ser testados e analisados pela comunidade científica, podendo se tornar ou não um modelo científico. Os modelos analógicos também não são exclusivos do contexto educacional. Os cientistas também se utilizam das analogias para formalizar ou esclarecer seus modelos mentais e seus modelos expressos que são apresentados à comunidade científica ${ }^{14}$.

Em resumo, em nossa pesquisa consideramos como relevante e recorremos ao longo do texto às noções de modelo mental, modelo analógico, modelo expresso, modelo conceitual e modelo científico. Apesar de citarmos o modelo teórico, o modelo matemático e o modelo consensual neste subcapítulo, não os retomaremos no restante do texto, uma vez que suas importâncias em nossa pesquisa, e o que levou a citá-los, restringem-se somente ao fato deles serem necessários ou úteis para melhor definir as noções de modelos científico e conceitual.

\footnotetext{
${ }^{14}$ Uma interessante abordagem sobre o papel das analogias na elaboração de modelos científicos é apresentado pela filósofa da ciência Mary Hesse. Em seu livro publicado em 1963, chamado de Models and Analogies in Science, a autora descreve o papel do que ela chama de analogias formais e analogias materiais no desenvolvimento da ciência.
} 


\subsection{3- As representações gráficas computacionais são modelos?}

Ao definirmos um modelo mental, o consideramos como uma representação mental de um objeto material ou abstrato. Desta definição poderíamos concluir equivocadamente que o termo representação é um sinônimo do termo modelo e, por consequência, poderíamos considerar que assim como uma representação mental é um modelo mental, uma representação pictórica, por exemplo, poderia ser dita como um modelo pictórico.

Entendemos a representação como algo que busca demonstrar outra coisa: é uma forma de apresentar determinado objeto ou entidade. Alguns autores do campo da filosofia da ciência e da educação (BLACK, 1962; HARRISON; TREAGUST, 2000; GILBERT, 2004) poderiam considerar o que definimos como uma representação como um sinônimo de modelo. Black (1962), por exemplo, considera um mapa, que é uma representação de limites geográficos por meio de desenhos, como um tipo de modelo em escala de determinado objeto de estudo.

Para nós, entretanto, um modelo é uma representação, mas nem toda representação é um modelo. Modelos não são sinônimos das representações, mas sim um subgrupo delas. Em nossa visão um modelo é uma representação mais elaborada que incorpora ideias, pressupostos e conceitos, e é nesse sentido que afirmamos anteriormente que um modelo é uma representação estruturada. Portanto, podemos afirmar que nem toda representação expressa é um modelo expresso. Assim, por exemplo, um desenho de um átomo, ainda que seja uma representação de um átomo, não seria um modelo. Já o conjunto de ideias, pressupostos e conceitos que compõem uma estrutura, o qual leva à representação de um átomo de uma determinada forma, definimos como um modelo.

Logo, descartamos definir como um modelo uma representação gráfica computacional (imagens digitais, animações e simulações), ou mesmo uma representação física (uma maquete, um experimento, etc.). Assim, uma simulação computacional é, por exemplo, um tipo de representação, uma imagem dinâmica que pode ser controlada em algum grau. Simulações computacionais podem ser elaboradas baseando-se em modelos conceituais e segundo modelos matemáticos que determinarão sua dinâmica; mas não as definimos como modelos, mas sim como representações de aspectos específicos de um modelo conceitual, que inclusive permitem o teste de aspectos deste modelo conceitual. 
Desta definição de representação que adotamos, podemos afirmar que o domínio análogo, presente no esquema de Duit apresentado na Figura 3 e em nosso esquema adaptado apresentado na Figura 6, é sempre uma representação. Assim, ao definirmos os recursos computacionais gráficos como representações, os situamos como um domínio análogo, em que a partir de relações de analogia com o objeto de estudo alvo relacionado a um modelo conceitual, podem permitir a compreensão de diferentes aspectos, propriedades e fenômenos deste modelo conceitual. Com isso, estamos afirmando que todo o uso de simulações são também situações de analogia, em que professores e alunos estabelecem relações analógicas entre elementos da simulação computacional e do modelo conceitual alvo, com o intuito de promover ou alcançar a compreensão deste último.

$\mathrm{Na}$ literatura em ensino de ciências, os estudos sobre as analogias normalmente focam as relações analógicas expressas verbalmente, e em alguns casos também são utilizadas representações gráficas. Como exemplo, há estudos que tratam das formas como um professor apresenta um conteúdo utilizando analogias e representando os análogos por desenhos. Em nosso trabalho, nas situações didáticas analisadas, as simulações computacionais são utilizadas de forma semelhante aos desenhos feitos por professores enquanto utilizam analogias, ocupando também um papel de análogo. Além disso, essa relação analógica que se estabelece com o uso das simulações computacionais ocupa um lugar de destaque no processo de ensino-aprendizagem investigado, inclusive assumindo uma função central no desenvolvimento das atividades.

\section{3- Abordagens sobre os modelos e analogias na literatura}

$\mathrm{Na}$ literatura em educação e ensino de ciências, e especialmente na perspectiva cognitiva, há um consenso sobre o importante papel que a analogia possui na formação de significados e na compreensão do que nos rodeia. São muitos os pesquisadores que destacam a importância do processo analógico no pensamento humano. Gardner (1995), por exemplo, afirma que o processo analógico é inerente ao pensamento, e o indivíduo desde a sua mais tenra idade utiliza as analogias como um mecanismo cognitivo para compreender o mundo. $\mathrm{Na}$ mesma linha, Duit et al. (2001) afirmam que, em uma perspectiva construtivista, o raciocínio analógico é uma característica chave no processo de aprendizagem, de 
forma que tal processo incluiria a busca de semelhanças entre o novo desconhecido e o conhecido.

Em uma revisão da literatura, Duarte (2005) cita algumas potencialidades do uso de analogias identificadas por ela na literatura, entre as quais, destacamos o fato das analogias tornarem o conhecimento científico mais inteligível e plausível, o que facilita a compreensão e "visualização" de conceitos abstratos. Coll, France e Taylor (2005) identificam esta mesma potencialidade ao afirmarem que as analogias surgem de forma espontânea em ambientes de ensino, como uma resposta às dificuldades que os alunos apresentam na compreensão dos conceitos.

Duarte (2005) destaca ainda diversas dificuldades e problemas que se apresentam com o uso das analogias. Segundo a autora, o análogo pode ser interpretado como o próprio objeto de estudo, ou mesmo pode-se ficar preso a aspectos mais evidentes da analogia, em detrimento do que se pretende passar com a analogia. Também é possível que, de certa forma, se desvalorize as limitações da analogia, prendendo-se unicamente nos aspectos positivos. Além disso, cita-se a possibilidade do raciocínio analógico não ocorrer de forma a levar a uma compreensão do alvo da analogia.

No que se refere ao estudo dos modelos, conforme já afirmamos, este é discutido na literatura em ensino de ciências de forma bem próxima ao estudo das analogias. A discussão sobre o uso de modelos e analogias no ensino de ciências está atrelada a duas abordagens principais, uma que define a construção de modelos conceituais e científicos em sala de aula como uma forma de alfabetização científica; e outra que, se situando em uma perspectiva mais próxima da visão cognitivista, se aprofunda no estudo sobre a construção dos modelos mentais a partir do uso de analogias, e sobre a relação dos modelos mentais com os modelos conceituais. Contudo, não são abordagens divergentes, de forma que as vemos não somente como possuindo, em alguns trabalhos, uma gênese e contexto em comum, mas também em muitos casos amparadas pelas mesmas noções principais (por exemplo, a noção de modelos científicos). Assim, diríamos que são abordagens complementares e que se misturam em algumas pesquisas.

$\mathrm{Na}$ primeira abordagem, em uma perspectiva do ensino e aprendizagem orientada à modelização, pesquisadores como Coll, France e Taylor (2005) afirmam que o papel crucial dos modelos na prática científica já é uma justificativa suficiente 
para a inclusão da discussão sobre modelos no ensino de ciências. Estes e outros autores (GOBERT; CLEMENT, 1999; KHAN, 2007; SCHWARZ; WHITE, 2005; VALK; DRIEL; VOS, 2007) entendem que como fazer ciência consiste em propor e testar modelos, uma educação científica mais "autêntica" deveria, também, empregar processos em que os alunos testam e propõem modelos.

Já partindo de uma perspectiva cognitivista, a segunda abordagem enfatiza a construção de modelos mentais, descrevendo e caracterizando os processos, as facilidades e as dificuldades na construção destes modelos. Esta perspectiva está bem representada no esquema proposto por Clement (2000) que apresentamos anteriormente. Os alunos chegam à sala de aula de ciências com diferentes experiências culturais, educacionais e pessoais, e este conjunto de concepções e experiências influenciam na construção de seus modelos mentais. Ao avançar em uma proximidade ao modelo conceitual, de certa forma ocorre uma reorganização das estruturas cognitivas, e os elementos que atuam nesta reestruturação são alvos de investigação na perspectiva cognitivista.

Na presente pesquisa estão presentes as duas abordagens sobre modelos: como nosso estudo envolve um curso sobre estrutura da matéria e aceleradores de partículas em que atividades foram desenhadas de forma a promover, entre outros objetivos, a proposição e validação de modelos científicos, a primeira abordagem está presente; ao mesmo tempo, ao definirmos a aprendizagem como um processo em que modelos mentais evoluem se aproximando de um modelo conceitual alvo, assumimos também a abordagem de modelos e analogia que se aproxima da perspectiva mais cognitivista. No entanto, nos desprendendo da perspectiva cognitivista exclusiva, buscando aproximar o nosso estudo aos contextos reais de sala de aula, focamos nossa análise nos obstáculos epistemológicos e didáticopedagógicos que impedem uma evolução dos modelos mentais. O Capítulo 5, apresentado à frente, é dedicado a descrever estes obstáculos. 


\section{5- OBSTÁCULOS DE APRENDIZAGEM: BROUSSEAU E BACHELARD}

O educador francês Guy Brousseau, considerado por muitos como o pai da didática matemática por ser um dos principais pioneiros no estudo na área, descreve em sua teoria das situações didáticas (BROUSSEAU, 1997; 2008) alguns dos obstáculos que emergem em situações de ensino e aprendizagem da matemática. Brousseau, tomando resultados de pesquisas realizadas e se inspirando nas ideias de ruptura do filósofo da ciência Gastón Bachelard, afirma que:

A aprendizagem apresenta frequentes rupturas, que podem ter origens e
formas variadas: saltos informacionais, mudanças na forma de controle
(proto, para ou matemático), origem ontogenética, escolha didática,
contingência epistemológica etc. Algumas das concepções adquiridas não
desaparecem imediatamente em benefício de uma concepção melhor:
resistem, provocam erros, tornando-se, então, "obstáculos" (BROUSSEAU,
2008, p. 48).

No trecho citado, podemos perceber que Brousseau identifica obstáculos de diferentes naturezas na aprendizagem da Matemática. Algumas rupturas como a escolha didática, os saltos informacionais e as mudanças na forma de controle, ainda que Brousseau não exponha explicitamente em seu texto, parecem convergir para o que ele chama de "obstáculos didáticos". Já as rupturas de origem ontogenética e as de contingência epistemológica, estão relacionadas, respectivamente, aos obstáculos ontogenéticos e epistemológicos. Estes três tipos de obstáculos são observados por Igliori (2008) em sua leitura de Brousseau:

Brousseau amplia a tipificação de obstáculo no sistema didático considerando três tipos: os de origem ontogênica, que são aqueles que se processam a partir de limitações de ordem do tipo neurofisiológicas, entre outras, do sujeito, no momento de seu desenvolvimento; os de ordem didática, que dependem somente das escolhas realizadas para um sistema educativo; e os de ordem epistemológica, que são aqueles dos quais não se pode nem se deve escapar, pois são constitutivos do conhecimento visado (IGLIORI, 2008, p. 127-128).

Embora Brousseau tenha definido os obstáculos de aprendizagem no âmbito da educação matemática, acreditamos que estes não são exclusivos desta área, encontrando lugar também na educação em ciências, como nos processos de ensino-aprendizagem da Física. Em especial os obstáculos epistemológicos, atuam de forma decisiva na aprendizagem de conceitos físicos, e inclusive a noção de obstáculo epistemológico foi definida originalmente por Bachelard no âmbito da 
filosofia da ciência para tratar a construção histórica das ideias das ciências físicas e químicas.

Os obstáculos ontogenéticos seriam aqueles associados ao desenvolvimento do sujeito. Para melhor compreender este tipo de obstáculo, podemos nos remeter aos estágios do desenvolvimento humano, algo proposto e descrito por Piaget (1972). Segundo Piaget, o ser humano passa por estágios de desenvolvimento (sensório-motor, pré-operatório, operatório concreto e operatório formal) que, entre outras coisas, dizem respeito ao que o sujeito pode aprender segundo a sua idade. Um obstáculo ontogenético poderia se manifestar, por exemplo, quando se objetiva ensinar um determinado modelo conceitual explorando a abstração, própria de um estágio operatório formal, para sujeitos que pela sua idade estariam em estágios de desenvolvimento anteriores. Vale ressaltar, no entanto, que um obstáculo ontogenético não se restringiria unicamente às limitações devido à idade do sujeito, mas também poderiam estar associados às condições especiais do sujeito. Ou seja, sujeitos com algum tipo de deficiência intelectual ou um transtorno de aprendizagem teriam limitações, as quais também podem ser definidas como obstáculos ontogenéticos.

$\mathrm{Na}$ presente pesquisa, apesar de reconhecermos a importância dos obstáculos ontogenéticos na aprendizagem, e por isso nos dedicamos a apresentar uma breve descrição, não os consideraremos em nossas análises. Isso, pois os alunos participantes da pesquisa possuem idades em que, presume-se, já estariam em estágios mais avançados do desenvolvimento. Caso os contextos investigados envolvessem turmas inclusivas de Física da Educação Secundária, que contassem com alunos com deficiência intelectual ou algum transtorno de aprendizagem diagnosticado, uma análise considerando os obstáculos ontogenéticos seria não somente útil como talvez necessária. Como este não é o caso dos participantes deste estudo, e como não buscamos responder questões mediante um olhar a nível cognitivo mais profundo e restrito, os obstáculos ontogenéticos assumem um papel pouco relevante em relação aos contextos e objetivos da pesquisa, e por isso, não são explorados aqui. 
Em relação aos obstáculos didáticos, estes podem ser definidos como eleições didáticas inadequadas ou pouco-adequadas ${ }^{15}$ feitas pelos professores no planejamento da aula ou durante a situação de aula. O reconhecimento e a superação de tais obstáculos por parte do professor, no próprio decorrer da aula, é algo importante para a promoção da aprendizagem, afinal, tais obstáculos podem levar os alunos a erros decisivos que impediriam a continuidade na construção do seu conhecimento.

A nosso ver, as eleições didáticas muitas vezes são influenciadas por aquilo que comumente se encontra instituído na prática docente e, portanto, não são exclusivas de um professor. As eleições didáticas são compartilhadas como parte dos saberes docentes e são influenciadas pelo material didático utilizado, o qual também possui alguma relação com os saberes docentes e com o processo de transposição didática (CHEVALLARD, 2009). Considerando isso, podemos redefinir este tipo de obstáculos como tendo uma natureza mais ampla: didática e pedagógica. Isto permite não somente reconhecer o papel individual do professor, mas também situá-lo em um contexto educacional mais amplo. Neste sentido, as eleições didáticas passam a ser entendidas não somente em um nível micro da ação do professor, mas também em um nível macro, que inclui a transposição do saber científico para um saber a ser ensinado. Ao considerar esta noção mais ampla, assim como o faz Pietrocola (2008), podemos substituir o termo utilizado por Brousseau por obstáculos didático-pedagógicos.

Os obstáculos didático-pedagógicos, sendo fruto de escolhas didáticas inadequadas ou pouco adequadas na apresentação e discussão de determinados modelos conceituais, podem acabar por reforçar concepções que não são suficientes para explicar um modelo conceitual alvo, concepções estas que deveriam, em alguns casos, ser superadas para uma adequada compreensão do modelo conceitual. As concepções, que em essência são formas de conhecer e de conhecimento, podem ter sido úteis para o tratamento de determinados conceitos, mas se mostram insuficientes para novos conceitos que se pretende ensinar, e assim, tais concepções atuam como obstáculos epistemológicos. Em outras

\footnotetext{
${ }^{15}$ Vale notar que dificilmente um professor escapa das escolhas pouco-adequadas ou inadequadas, visto que as condições de ensino, a heterogeneidade das turmas e mesmo as necessárias adaptações do saber resultam em inadequações. Mais do que evitar completamente essas inadequações de todas as ordens, valeria ter consciência de sua ocorrência e dos meios de corrigilas, ou em nossos termos, superá-las no decorrer do processo de ensino-aprendizagem.
} 
palavras, os obstáculos epistemológicos, que conforme veremos à frente podem surgir naturalmente no processo de aprendizagem, podem ser reforçados mesmo sem a intenção do professor, de acordo com as suas escolhas didáticas.

Os obstáculos epistemológicos, noção proposta inicialmente pelo filósofo da ciência Bachelard para tratar a construção histórica das ideias das ciências físicas e químicas, podem ser definidos como formas de conhecer já utilizadas pelo sujeito durante a aprendizagem, mas que acabam por impossibilitar a continuidade desta.

Dada a relevância da noção de obstáculo epistemológico para a presente pesquisa, julgamos pertinente uma descrição mais detalhada desta segundo a perspectiva de Bachelard, e para isso dedicamos o subcapítulo 5.1. Após, no subcapítulo 5.2, para melhor definir os obstáculos epistemológicos enquanto obstáculos de aprendizagem, retomaremos as ideias de Brousseau e de outros pesquisadores em educação que têm utilizado a noção de obstáculos epistemológicos. Por fim, ao final deste capítulo, buscaremos no subcapítulo 5.3 convergir as diferentes vertentes teóricas que elencamos neste estudo, em função dos objetivos e da delimitação da pesquisa.

\section{1- Obstáculos epistemológicos na perspectiva de Bachelard}

Para Bachelard, os obstáculos epistemológicos seriam as dificuldades do pensamento na superação de formas preestabelecidas de conhecer. Em outras palavras, seriam dificuldades do pensamento associadas ao ato de conhecer, que impedem que se continue a conhecer. Ao se referir aos obstáculos epistemológicos, Bachelard afirma que:

[...] não se trata de considerar obstáculos externos, como a complexidade e a fugacidade dos fenômenos, nem de incriminar a fragilidade dos sentidos e do espírito humano: é no âmago do próprio ato de conhecer que aparecem, por uma espécie de imperativo funcional, lentidões e conflitos (BACHELARD, 1996, p.17).

Assim, para Bachelard os obstáculos epistemológicos são inerentes ao próprio ato de conhecer. Não são ações externas ao conhecimento, mas o próprio conhecimento e as formas com que estes são construídos que se estabelecem como obstáculos epistemológicos.

Pela natureza deste tipo de obstáculo, por envolverem o conhecido e o modo como se tornou conhecido, é possível concluir que basta que se busque 
construir conhecimento para que se tenha um terreno fértil ao surgimento e ação dos obstáculos epistemológicos. Neste sentido, Lopes (1993b, p.326) afirma que se faz necessário um constante trabalho de superação dos obstáculos epistemológicos, afinal, por estes serem intrínsecos ao conhecimento, eles estão sempre presentes.

Segundo Bachelard (1996), é nos obstáculos epistemológicos que se encontram as causas de estagnação e até de regressão no desenvolvimento da ciência. Bachelard encara a racionalidade do conhecimento científico como uma ruptura com seus princípios e não como um aperfeiçoamento da racionalidade do senso comum. Neste sentido, admite que a história do pensamento humano é uma história de superação, onde o pensamento supera a si mesmo. No caso do pensamento científico, este supera o pensamento pré-científico (anterior ao século $X V I I I)$, que é superado pelo novo pensamento científico que se instala no século $X X$.

Podemos relacionar os obstáculos epistemológicos com a ideia da ciência como sendo um conhecimento aproximado, algo que tratamos sucintamente no subcapítulo 2.1. O pensamento pré-científico, que se baseia em um conhecimento concreto, é aquele que se constrói a partir a percepção ingênua, do primeiro contato com a natureza. Tal pensamento traria o mérito de se basear diretamente no mundo, embora num olhar da ciência atual tenha um alto grau de ingenuidade. Com o advento da experimentação e dos métodos científicos que a direcionam, o contato com a natureza passa a ser não mais direto. Constrói-se então um conhecimento concreto-abstrato: a ciência clássica, que consiste em uma aproximação de primeira ordem. O conhecimento anterior, concreto, pela sua percepção fácil no mundo real, pode acabar por atuar dificultando ou impedindo a construção do conhecimento concreto-abstrato. A forma de conhecer mais direta relacionada ao conhecimento concreto seria, assim, um obstáculo epistemológico ao conhecimento concreto abstrato. Neste sentido, Bachelard afirma que:

[...] o espírito científico deve formar-se contra a Natureza, contra o que é, em nós e fora de nós, o impulso e a informação da Natureza, contra o arrebatamento natural, contra o fato colorido e corriqueiro (BACHELARD, 1996, p. 29).

Já a ciência moderna, que se constrói baseada em fenômenos tecnicamente relevantes, ou seja, em que a técnica não irá se separar do fenômeno estudado, constitui-se como um conhecimento abstrato, como uma aproximação de segunda ordem. Acrescente-se que tal conhecimento abstrato é fenomenotécnico nos termos 
que discutimos no subcapítulo 2.1. A construção do conhecimento abstrato presente na ciência moderna envolveu a superação do conhecimento clássico e de suas formas de conhecer, as quais podem atuar também como obstáculos epistemológicos.

Portanto, a ciência ocorre segundo uma construção que se dá na medida em que são superados os obstáculos epistemológicos erigidos numa época para conhecer, mas que impedem o pensamento de continuar a conhecer. Os obstáculos epistemológicos são os motores e, ao mesmo tempo, os freios do pensamento científico, são as aproximações e o que impedem outras aproximações.

Bachelard (1996), ao analisar a construção científica, apresenta alguns tipos de obstáculos epistemológicos por ele identificados e classificados, entre os quais aqueles que estão intimamente relacionados ao uso de representações, analogias e metáforas na ciência. Dedicamos as próximas linhas a expor esta tipologia:

O primeiro obstáculo epistemológico, a experiência primeira, está relacionado ao contato mais direto e inicial com o fenômeno. Neste contato, se substitui a explicação científica por uma apreciação do fenômeno, da imagem. O pensamento se apega mais à beleza do fenômeno do que à explicação dele. Assim, o conhecimento se constrói não pela razão, mas detendo-se em uma descrição do atrativo que é facilmente perceptível. Por exemplo, na história da ciência, Poncelet ${ }^{16}$ (1769 apud BACHELARD, 1996, p. 31) ao escrever sobre o trovão, se apega a uma descrição sobre o medo e outros aspectos desagradáveis que o trovão provoca nas pessoas, e não a uma busca pela explicação do que de fato ocasiona o fenômeno.

Conforme assinala Ferry (2008, p. 50), o sujeito coloca muito de si no ato de conhecer, e o objeto de estudo é interpretado, por exemplo, "[...] com toda carga de cultura, expectativas, vontades e facilidade que experiência primeira oferece". Neste sentido, Mendonza (2008) destaca que ao tentar compreender as leis que regem ou permitem existir um fenômeno, como o espírito não se apresenta desnudo e sem um conjunto de pré-conceitos, não há, de fato, um contato com a nova realidade isento do anteriormente conhecido. Assim como afirma Ferry (2008, p.50), o conhecimento científico constrói-se impregnado de traços subjetivos, imaginários e afetivos; e tais traços, fortemente relacionados aos obstáculos epistemológicos, escapam do

\footnotetext{
${ }^{16}$ PONCELET, A. La Nature dans la formation du Tonnerre et la reproduction des Etres vivants, 1769.
} 
controle dos cientistas (ou filósofos naturais), constituindo um inconsciente científico que perturba a atividade científica.

Outro obstáculo é o denominado conhecimento geral. Trata-se de um conhecimento que se constrói prematuramente, muitas vezes como uma consequência do obstáculo da experiência primeira. Este conhecimento é fechado e o espírito científico a ele submetido o vê como tão claro e certo que tem dificuldade no ato de continuar a conhecer. Baseando-se em um conhecimento geral as perguntas são respondidas facilmente, tendo-se respostas únicas, fixas e vagas para qualquer questionamento, e ainda assim, tais respostas possuem uma considerável precisão e coerência interna em relação ao próprio conhecimento geral que as origina. Bachelard classifica como um obstáculo do conhecimento geral a noção aristotélica sobre a queda dos corpos. Para Aristóteles, os corpos deveriam buscar o seu lugar natural, e por isso, alguns corpos como as pedras, caíam até o solo, enquanto outros como o vapor e a fumaça subiam, também buscando o seu lugar natural. Assim, este conhecimento responde facilmente o porquê de um objeto cair ou subir, e esta resposta é fiel e consistente do ponto de vista do próprio conhecimento que a explica. Com este obstáculo, a resposta é clara, objetiva e fácil, e um espírito pré-científico se daria por satisfeito com esta resposta. Bachelard (1996, p.69) afirma que nada prejudicou tanto o desenvolvimento da ciência como este tipo obstáculo epistemológico, e segundo ele, o conhecimento geral dominou desde Aristóteles até Francis Bacon.

Já o obstáculo verbal, um terceiro tipo de obstáculo epistemológico, consiste em substituir toda uma explicação e conjunto de ideias por uma única palavra ou imagem, constituindo-se assim como uma falsa explicação. É também o uso abusivo e não cauteloso das imagens familiares. A imagem familiar é utilizada como se fosse uma evidência clara, que não necessita ser explicada. Assim, ela ocupa um papel de metáfora, ocultando as semelhanças, ou como no exemplo que destacamos a seguir, constrói todo um conjunto de ideias a partir de semelhanças entre a imagem primitiva e o objeto de estudo, o que em nossa definição que apresentamos no item 4.1, se aproximaria mais de uma relação de analogia. Um exemplo citado por Bachelard é o uso da palavra esponja, que na história da ciência 
teria sido utilizada para explicar variados fenômenos. Franklin ${ }^{17}$ (1752 apud BACHELARD, 1996, p. 94) utiliza a palavra "esponja" para explicar a diferença entre a "matéria elétrica" e a "matéria comum". Sua explicação apoia-se totalmente na imagem primitiva da esponja, e dela extrai suposições e estabelece relações de analogia para explicar o fenômeno físico. Segundo Bachelard, Franklin fica somente no plano da esponja, sendo esta assumida como uma categoria empírica para gerar as suposições. Neste exemplo, o uso da palavra "esponja" e suas características, constituem-se um obstáculo ao conhecer, por não serem utilizados nada mais que os elementos próprios do análogo.

Outro obstáculo epistemológico é o chamado conhecimento unitário e pragmático. Assim como no conhecimento geral, o conhecimento unitário está relacionado à generalidade das coisas, mas em um nível mais amplo. conhecimento unitário, ao considerar a natureza como única, estabelece que o que se utiliza para explicar o grande, pode-se utilizar para explicar o pequeno, sendo o contrário igualmente válido. Como o todo é uma unidade, o entendimento de qualquer parte do universo físico poderia ser utilizado para explicar outra parte. Esta noção geral e unitária leva a conclusões precipitadas e com um mínimo esforço. Entre os exemplos fornecidos por Bachelard, destacamos um: a partir de um entendimento unitário do universo, Fayol $^{18}$ (1672 apud BACHELARD, 1996, p. 110) afirma que as mudanças dos reinos e religiões ocorrem em função das mudanças dos planetas.

Em relação ao pragmatismo, ele gera conclusões precipitadas, fáceis e, além disso, exageradas. Para Bachelard (1996, p.114) todo "[...] pragmatismo, pelo simples fato de ser um pensamento mutilado, acaba exagerando". Bachelard apresenta um exemplo, no qual Berthollet ${ }^{19}$ (1776 apud Bachelard, 1996, p. 114) afirma que a transpiração suprimida na infância levaria a um aumento das vias urinárias, firmando assim um fluxo mais abundante. Neste exemplo, o pensamento pragmático leva a uma conclusão lógica, porém precipitada, que não somente apresenta-se como exagerada, mas de certa forma absurda.

\footnotetext{
17 FRANKLIN, B. Expériences et observations sur 1'électricité, communiquées dans plusieurs Lettres a P. Collinson de la Soe. Roy. de Londres. Trad. Paris, 1752, p. 135.

${ }^{18}$ FAYOL, J. B. Prieur commendataire de Notre-Dame de Donges. UHarmonie celeste. Paris, 1672, p. 81-82.

${ }^{19}$ BERTHOLLET. Observations sur l'air, 1776, p. 31
} 
O obstáculo substencialista, outro tipo de obstáculo, consiste na atribuição de qualidades materiais ao objeto de estudo, e não propriedades e características que podem de alguma forma ser inferidas e/ou medidas. Tais qualidades são muitas vezes íntimas e ocultas, e conhecer o íntimo do objeto é conhecer a essência do próprio objeto. É um estudo do íntimo e do profundo, mas que ao final releva conclusões superficiais. Como exemplo, $\operatorname{Poleman}^{20}$ (1721 apud BACHELARD, 1996, p. 124), ao falar do enxofre, afirma que o azeite é capaz de dissolver de forma suave e natural o enxofre, levando o que está dentro para fora. Uma noção por detrás da afirmativa é que o íntimo do objeto, por possuir a sua essência, ao ser levado ao externo, purifica o objeto.

Para Bachelard, o realismo também pode se apresentar como um obstáculo epistemológico. Neste, o entendimento está diretamente relacionado à presença do real, de tal forma que este real não necessita ser estudado ou ensinado. O real é interpretado de tal forma autoevidente, possuindo um valor em si mesmo que não precisa ser discutido. Bachelard discute este obstáculo se remetendo à história dos fármacos, e entre os exemplos, cita um tratado do século XVIII de Geoffroy ${ }^{21}$, no qual, partindo de um valor evidente relacionado às pedras preciosas, atribui à esmeralda um poder de cura de hemorragias quando esta pedra é utilizada como um remédio. Destaca-se também a defesa de Geoffroy contra os que dissessem que a esmeralda não seria dissolvida no estômago, em que ele afirma que tal como a brasa extrairia da pedra a sua cor, o calor natural e a linfa do estômago removeriam da pedra as partes sulfurosa e metálica que atuariam nos líquidos do corpo humano. Segundo Bachelard, a cor substantifica um valor do mineral, e uma possível descoloração das esmeraldas pela ação estomacal não seria mais que uma substituição "[...] do prazer que se tem ao contemplar o brilho verde e suave da esmeralda" (BACHELARD, 1996, p. 167). O apoio no valor agregado a um objeto para inferir características, como a da esmeralda como um fármaco, é o que leva Bachelard a afirmativa de que todo realista é um avarento, e todo avarento é um realista.

\footnotetext{
${ }^{20}$ POLEMAN, J. Nouvelle lumière de Médecine du mistere du souffre des philosophes. Trad. do latim. Rouen, 1721, p. 5.

${ }_{21}$ GEOFFROY. Traité de la Matière médicale ou de 1 'histoire des vertus, du choix et de 1'usage des remèdes simples. Paris, 17Ai, v. 1, p. 157-158. Citado por Bachelard (1996, p. 166).
} 
O obstáculo animista, outro mais pertencente à tipologia de Bachelard, se apresenta pela atribuição de vida ao que não tem, ou pela concessão de um valor maximizado à vida e aos seres viventes. Como exemplo De Bruno ${ }^{22}(1785$, p.15 apud BACHELARD, 1996, p. 188-189) ao descrever o comportamento do ímã, o faz por analogias utilizando características próprias de seres vivos. De forma semelhante, imperfeições como a ferrugem são definidas também por De Bruno (1785, p.123 apud BACHELARD, 1996, p. 194) como uma doença ao qual está suscetível o ferro. Deste exemplo, percebemos que o obstáculo animista não somente ocorre quando se atribui vida aos seres inanimados para a explicação de fenômenos, mas também quando aos seres inanimados que são estudados atribuise situações próprias dos seres viventes.

Outro obstáculo enunciado por Bachelard é o chamado mito da digestão. Segundo Bachelard, entre os séculos XVI e XVIII o estômago é compreendido como uma máquina eficiente, pois tritura alimentos sem ruídos, dissolve sem ser corrosivo, e funde sem ser fogo. A digestão é comparada como um fogo em um forno, em que o forno seria o corpo humano. Assim, caberia à química instruir-se a partir dos processos digestivos, que trazem consigo a "química natural". Não se reduzindo somente à comparação do estômago com uma máquina, o entendimento da digestão é estendido e aplicado no entendimento do próprio universo, que também seria semelhante a um estômago que tritura e digere. Desde o mito da digestão se conclui ainda que o alimento sólido e consistente seria o mais valioso, pois está ligado a um sentido de posse do estômago, é ele que sentiria fome para suprir o corpo, e é o alimento sólido que extingue a fome. Já os líquidos suprem a sede, que é entendida como uma manifestação do corpo enfermo. Segundo Bachelard (1996, p.210), citando escritos do século XVII, enquanto a fome é entendida como natural, a sede é vista como contra a natureza, em que "os que estão febris têm sede, os convalescentes têm fome". A influência do mito da digestão na ciência é exemplificada por Bachelard (1996, p. 216) com uma descrição presente na conhecida Encyclopédie, em que se comenta que para a preparação do aço, além do ferro, podem ser utilizadas partes de animais, que possuem em si um valor por se tratarem de alimentos sólidos.

${ }^{22}$ DE BRUNO. Recherches sur la direction du fluide magnétique. Amsterdã, 1785, p. 123. 
Bachelard destaca ainda mais um obstáculo epistemológico, a Libido. Segundo ele, se manifestando muitas vezes disfarçado no discurso metafórico, tal obstáculo reside na influência da libido no conhecimento objetivo. Para Bachelard, a sexualidade, sempre presente e ativa no inconsciente, é empregada na descrição de processos, fenômenos e partes de um objeto de estudo. Tratar o interior de materiais como ventre, corpos envolvidos em interações sendo classificados como ativos ou passivos, ou a metais como o mercúrio se atribui propriedades como a esterilidade, entre outros, são alguns dos exemplos de manifestação deste obstáculo destacados por Bachelard.

Um último obstáculo, o conhecimento quantitativo, surge a partir da consideração de que todo o conhecimento quantitativo é livre de erro, e de uma ideia de que tudo o que se pode contar tem uma validade maior do que o que não pode ser quantificado. Uma consequência desse obstáculo no campo da Física seria, por exemplo, a dedicação exagerada a uma precisão numérica, afastando o conhecimento quantitativo de sua função em amparar o conhecimento físico, o que certa forma, distraindo o espírito pré-científico, teria um efeito semelhante ao mais básico dos obstáculos epistemológicos, o da experiência primeira. O conhecimento quantitativo, isentando-se de um sentido físico, pode ter as mesmas regras e definições para o grande e para o pequeno, o que pode tornar este tipo de conhecimento falho, e ainda mais, um obstáculo. Bachelard traz alguns exemplos deste tipo de obstáculo, entre eles um relato de um cálculo datado do século XVIII, o qual deduz que a Terra teria se desprendido do Sol há exatos 74.832 anos do momento em que se afirmava isto, e que em 93.291 anos a Terra se resfriaria de tal modo que impossibilitaria a vida (CURVIER ${ }^{23}, 1844$ apud Bachelard, 1996, p. 190). Segundo Bachelard, tal predição tão exata é tão surpreendente como são vagas e particulares as leis físicas que levaram a este cálculo.

\section{2- Obstáculos epistemológicos na educação}

Ainda que as ideias de Bachelard tenham sido cunhadas principalmente a partir da primeira metade do século XX; são ideias atuais que encontram na educação, e especialmente no ensino das ciências, um campo fértil de aplicação. Já há alguns anos, suas ideias têm atraído o olhar de pesquisadores em ensino de

${ }^{23}$ CUVIER, G. Histoire des Sciences naturelles depuis leurs origines jusqu'à nosjours. Paris, $1844-1845,5$ v., v. 4 , p. 321. 
ciências e matemática (BROUSSEAU, 1983, 1986; LOPES, 1990; DELIZOICOV, 1991; MORTIRMER, 1996; ANDRADE; ZYLBERSZTANJ; FERRARI, 2002; MELO, 2005; SILVEIRA; DIAS; LEITE, 2006; GOMES; OLIVEIRA, 2007; FERRY, 2008).

$\mathrm{Na}$ obra de Bachelard não existem textos exclusivamente voltados para a questão educacional, mas com certa frequência ele apresenta algumas de suas análises filosóficas com interpretações a partir do conhecimento científico presente na escola (ANDRADE; ZYLBERSZTANJ; FERRARI, 2002). Como exemplo, Bachelard (1996, p. 23) define, sem se aprofundar em sua discussão, um tipo de obstáculo que é próprio da prática educativa, denominado por ele como obstáculo pedagógico. Seriam obstáculos que impedem que os professores de ciências compreendam o porquê de seus alunos não compreenderem. Bachelard (1996, p.21) também considerava que a noção de obstáculo epistemológico poderia ser estudada não somente no desenvolvimento histórico do pensamento científico, mas também na prática da educação.

Da tipologia proposta por Bachelard para os obstáculos epistemológicos apresentada anteriormente, muitos são os que a nosso ver poderiam estar presentes no processo de construção de conceitos nas salas de aula de Física e Química. Apenas a título de exemplo, o obstáculo da experiência primeira, que está relacionado ao repouso do conhecer sobre o belo ou diferente em prevalência à explicação, poderia se manifestar mediante o uso das TIC. Na educação em ciências em que se utilizam as TIC, em especial os recursos computacionais, estes podem ocupar o lugar da busca de conhecimento científico, assumindo algumas vezes um papel de ferramenta exclusivamente de distração ao conhecer, e não de meio que pode levar à construção de um conhecimento. O obstáculo verbal também pode se manifestar no ensino de ciências pelo mal uso de analogias e metáforas. Além disso, nos casos em que são utilizadas representações gráficas do análogo, o obstáculo verbal, que agora diríamos, está acompanhado de um obstáculo pictórico, pode prevalecer sobre o conhecimento que se espera que seja construído.

Outro obstáculo, o do conhecimento unitário e pragmático, pode se apresentar, por exemplo, no estudo de eletrostática. É comum que os estudantes e professores abordem este conteúdo a partir de casos optimizados, afinal esta é uma característica do modelo conceitual instituído, onde se consideram cargas pontuais em um estudo simplificado. Ao tomar este estudo específico como integralmente 
correspondente a todos os demais que envolvam corpos carregados (por exemplo, para cargas não pontuais), ao mesmo tempo em que há uma noção de unidade, há também uma extrapolação exagerada, típica do conhecimento pragmático. Esta extrapolação pode ser realizada não somente pelo estudante em uma tentativa de fazer com que o conteúdo tenha sentido, mas também por professores que caem no erro de tentar extrapolar o estudo sem adequações e novas considerações aos casos cotidianos que envolvam corpos carregados. Esta extrapolação inadequada não somente mostra-se incorreta do ponto de vista físico, como também pode levar a uma falsa compreensão de que o saber não é aplicável.

Em relação ao obstáculo animista, este pode se manifestar no ensino de ciências especialmente mediante a linguagem metafórica, quando se atribui qualidades, habilidades ou ações de seres vivos a entidades e fenômenos. No ensino de química, por exemplo, Lopes (1992, p. 256-257) elenca diferentes obstáculos animistas identificados em livros de química, entre eles, uma descrição da ligação iônica ocorrendo somente quando um átomo "tem vontade" de perder elétrons, e outro "tem vontade" de ganhar elétrons. O grande problema desta abordagem reside no fato da metáfora tomar o lugar da explicação, e assim, permitir que diversas outras características dos seres vivos sejam atribuídas a entidades inanimadas. Ou seja, se forma um obstáculo que impede o aluno de limitar a validade da metáfora. No ensino de Física este mesmo obstáculo pode aparecer, por exemplo, quando se busca explicar o comportamento das cargas elétricas, afirmando que uma carga pontual não "enxerga" um corpo eletricamente neutro. Neste exemplo, atribui-se metaforicamente um sentido dos seres vivos, a visão, a um objeto inanimado e idealizado. Igualmente corre-se o risco da metáfora ocupar o lugar da explicação científica. Para ambos os exemplos, uma vez que são utilizadas as metáforas, elas necessitariam ser desconstruídas, de preferência, logo após serem apresentadas.

Vale dizer que não estamos criticando radicalmente o uso de tais estratégias didáticas no ensino de Física e de Química, mas apenas apresentando exemplos de contextos que parecem propícios ao aparecimento de obstáculos, que se previamente conhecidos pelos professores e pesquisadores, podem ser superados em fases posteriores do processo de ensino-aprendizagem. 


\subsection{1- Ensino de ciências e matemática: características dos obstáculos} epistemológicos

Entre os pesquisadores que adaptaram as ideias de Bachelard ao ensino destaca-se o francês Guy Brousseau. Como mencionamos anteriormente, ele adequou as noções de ruptura e obstáculos epistemológicos redefinindo-as como dificuldades de ensino-aprendizagem relacionadas a um conhecimento já constituído, que impede a assimilação de novos conhecimentos (BROUSSEAU, 1983; 1986; 1997).

Brosseau (1997, p. 18-19) apresenta algumas características dos obstáculos epistemológicos no âmbito da educação matemática, as quais, a nosso ver, também são próprias da aprendizagem em ciências. Segundo ele, os obstáculos epistemológicos são sempre conhecimentos e formas de conhecer que podem ser aplicados em determinadas áreas (situações), e nesta aplicação, proporcionam resultados corretos e benefícios significativos, mas, no entanto, tornam-se falsos ou totalmente inadequados para uma nova ou maior área.

Outra característica citada por Brousseau (1997, p. 18), que está diretamente relacionada à ideia de ruptura, é a de que os obstáculos epistemológicos não possuem relações "lógicas" diretas como o novo conhecimento e que, portanto, necessitam ser superados, ou seja, o novo conhecimento constróise contra o conhecimento anterior. Conforme afirma Brousseau, o novo conhecimento exige novos olhares, outros métodos, os quais não foram aplicados na construção dos conhecimentos anteriores que necessitam ser superados. Brousseau (1997, p. 18-19) também afirma que os obstáculos epistemológicos não são variáveis pessoais, mas são "universais" para determinadas áreas específicas do conhecimento. Em outras palavras, para um mesmo modelo conceitual os mesmos obstáculos surgem em diferentes contextos com diferentes pessoas. Ele ainda afirma que um obstáculo epistemológico não desaparece com a aprendizagem de um conhecimento novo. Ele resiste à compreensão do novo, dificultando sua aplicação. O obstáculo epistemológico permanece em estado latente e reaparece inesperadamente assim que as circunstâncias permitirem.

No mesmo sentido, Camilloni (1997, p.12) afirma que como o obstáculo epistemológico é algo que já se sabe, ele gera uma inércia que acaba dificultando a construção do novo saber. Segundo a autora, tanto o cientista como o aluno, por 
não partirem do zero, ao se aproximarem da ciência já possuem crenças sobre os fenômenos.

Podemos afirmar que o conhecimento construído na experiência cotidiana, que é suficiente e eficiente para interpretar as ações, fenômenos e entidades presentes no dia a dia, o que comumente é chamado na literatura em ensino de ciências de concepções espontâneas, pode se apresentar como inadequado em uma análise mais minuciosa da realidade, e assim, as formas de construção das concepções espontâneas atuam como um obstáculo à construção de um conhecimento mais elaborado. Como exemplo, a percepção ingênua fruto da experiência cotidiana atua como obstáculo epistemológico na construção de conceitos próprios da Física Clássica.

Camilloni (1997), ao comentar em linhas gerais a natureza do conhecimento comum e sua resistência ao novo, ainda afirma que:

\footnotetext{
Este conhecimento, diferente do conhecimento científico e caracterizado como opinião, por sua natureza e o modo em que foi construído, permite lograr, na maioria das circunstâncias, uma adequada adaptação à satisfação das necessidades do sujeito porque este funda os conhecimentos em sua utilidade. Conhecimento comum, crença ou opinião, em sua origem se encontram diversos componentes de natureza social e individual: desejos, busca de segurança, experiências pessoais, mitos. Dali a resistência a desprender-se desses conhecimentos e substituí-los por outros (CAMILLONI, 1997, p.12-13, tradução nossa).
}

A afirmativa da autora vai ao encontro das características enunciadas por Brousseau. No entanto, cabe destacar que não somente o conhecimento comum, crenças ou opiniões estão relacionados com obstáculos epistemológicos, mas também a forma de conhecer empregada na construção de um conhecimento mais elaborado pode constituir-se como tal. Conhecimentos oriundos da Física Clássica seriam um exemplo que, conforme já comentamos nos capítulos introdutórios, podem se opor à compreensão das entidades e fenomenologias da Física Moderna e Contemporânea.

$\mathrm{Na}$ presente pesquisa adotamos a mesma definição de obstáculos epistemológicos proposto por Brousseau, que engloba a definição exposta por Camilloni (1997) apresentada acima. Assim, e em um resumo das características que expomos, entendemos que os obstáculos epistemológicos: são formas de conhecer (ou formas de construir conhecimento) úteis no ato de conhecer num certo momento histórico (do indivíduo ou da ciência), mas que impedem que se continue a 
conhecer. São forma de conhecer sem uma relação linear com o novo e que, portanto, para a compreensão do novo é necessária uma ruptura. São inerentes ao raciocínio científico e ao conhecimento científico, e assim, não são individuais, restritos a uma única pessoa. São também resistentes e não desaparecem.

Além disso, entendemos que as formas de conhecer próprias do conhecimento ingênuo ou comum atuam como obstáculo epistemológico à compreensão da Física Clássica; e entendemos que as formas de conhecer do conhecimento comum e daquele proveniente da Física Clássica pode constituir-se também como obstáculo epistemológico à compreensão da Física Moderna e Contemporânea.

\subsection{2- A face positiva dos obstáculos epistemológicos e dos erros}

Um elemento diferencial na filosofia da ciência de Bachelard em relação a outras abordagens filosóficas é sua posição sobre o papel do erro na prática científica. Ele parte da noção de que o incorreto é natural e não deve ser escondido, mas deve ser superado a partir da postura crítica. Lopes (1993b) afirma que Bachelard considera:

[...] a história das ciências como uma imensa escola, na qual existem os bons alunos e os alunos medíocres, enfatizando a importância de se trabalhar com a história de ambos: a transmissão de verdades e a transmissão de erros. O conhecimento das verdades nos faz entender as progressivas construções racionais. O conhecimento dos erros nos permite entender o que obstrói o conhecimento científico (LOPES, 1993b, p. 327).

Conforme aponta Lopes (1996), ao contrário de outros filósofos, Bachelard não interpreta o erro como um acidente lamentável ou uma imperícia a ser evitada, mas sim defende que é inevitável errar na ciência, pois é pela retificação dos erros que o conhecimento científico se constrói. Segundo esta autora:

Como seu objetivo não é validar as ciências já prontas, tal qual pretendem os partidários das correntes epistemológicas lógicas, o erro deixa de ser interpretado como um equívoco, uma anomalia a ser extirpada. Ou seja, com Bachelard, o erro passa a assumir uma função positiva na gênese do saber e a própria questão da verdade se modifica. Não podemos mais nos referir à verdade, instância que se alcança em definitivo, mas apenas às verdades, múltiplas, históricas, pertencentes à esfera da veridicidade, da capacidade de gerar credibilidade e confiança. As verdades só adquirem sentido ao fim de uma polêmica, após a retificação dos erros primeiros (LOPES, 1996, p.252-253, grifo do autor).

Brousseau (1997, p. 19), por sua vez, também destaca a importância dos erros, relacionando-os com os obstáculos epistemológicos. Para Brousseau, os 
obstáculos se manifestam pelos erros. Estes, quando associados a obstáculos epistemológicos, envolvem uma maneira de conhecer, uma concepção característica e coerente, mas incorreta, um conhecimento anterior eficaz em um determinado domínio de ações. Uma vez que os erros são indícios dos obstáculos epistemológicos, os erros devem ser alvo de ação do professor e de investigação do próprio aluno.

Conforme afirma Brousseau (1997, p. 19), deve-se rejeitar a negação dos obstáculos, mas como um requisito para a aprendizagem do novo conhecimento, o obstáculo deve ser visto como um constitutivo do conhecimento. Indo ao encontro dessa ideia, Camilloni (1997, p.14) defende que na educação científica não se deve pensar somente no que o aluno deve aprender, mas também naquilo que ele deve desaprender.

Considerando o que expusemos neste subcapítulo, podemos dizer que o erro nem sempre é um simples erro. Se por um lado o erro pode ser consequência unicamente do desconhecido, e o desconhecer não é em si um obstáculo epistemológico, por outro lado o erro pode assinalar algo muito além do desconhecer: pode estar associado e fundamentado no conhecido e em uma forma de conhecer que necessitam ser desconstruídos para que ocorra a construção do novo conhecimento, isto é, para que ocorra a aprendizagem do novo.

Em concordância com esta perspectiva positiva sobre o erro e os obstáculos epistemológicos e aceitando uma próxima relação entre ambos, entendemos como importante para o reconhecimento dos obstáculos epistemológicos, a manifestação dos alunos, seja mediante a linguagem oral e gestual em sua interação com o professor e demais alunos, ou pela exposição de representações por meio de imagens, esquemas, etc. Assim, e conforme será apresentado na discussão da metodologia, é na fala dos alunos e em outras formas de externalização das representações mentais, que ocorrem em situações de ensino e aprendizagem em sala de aula, que buscaremos identificar erros conceituais e associá-los com obstáculos epistemológico; e ainda, é no diálogo que se estabelece nestas situações que buscaremos identificar a argumentação utilizada para que os obstáculos sejam desconstruídos. 


\section{6- ANALOGIAS, MODELOS E OBSTÁCULOS NO ESTUDO SOBRE O ENSINO DE FMC COM O USO SIMULAÇÕES COMPUTACIONAIS}

Conforme já exposto, este trabalho possui como marco teórico um produto inspirado por correntes com interesses de estudo diferentes: uma corrente cognitivista envolvida no estudo dos modelos mentais e das analogias envolvidos no ensino de ciências; a epistemologia das ciências de Bachelard, que se ocupa de refletir sobre o desenvolvimento histórico do pensamento científico, e as noções de obstáculos de Brousseau, as quais são inspiradas nas ideias de Bachelard. De forma cautelosa procuramos estabelecer conexões entre estas correntes para um determinado objeto de estudo delimitado: a construção de modelos mentais a partir de relações analógicas que se estabelecem com o uso representações, em específico, as simulações computacionais.

Das ideias de Bachelard, nos é útil, em especial, a noção de fenomenotécnica para entender, entre outras coisas, o que deveria ser o alvo de estudo na aprendizagem de conceitos de FMC. Conforme nos dedicamos a descrever no capítulo 2, os conceitos de FMC possuem uma relevância técnica e rompem com o conhecimento ingênuo e com a Física Clássica. Em relação à relevância técnica, como não podemos separar qualitativamente o que é fenômeno e o que é técnica, o entendimento dos conceitos envolve também o entendimento da técnica e do conhecimento teórico que permite a técnica. Logo, no ensino dos conceitos envolvidos no tema Estrutura da Matéria, o modelo conceitual, ou seja, o modelo científico previamente didatizado que é alvo de aprendizagem, é composto não somente pelo estudo do fenômeno, mas da técnica que o origina. Assim, o modelo conceitual alvo é o conhecimento fenomenotécnico.

Considerando que a técnica utilizada na FMC é permeada por equipamentos sofisticados, longe do contexto escolar e, portanto, de difícil acesso aos estudantes, a discussão desta e dos fenômenos produzidos por ela requer algum meio representativo, por exemplo, recursos computacionais gráficos como as imagens estáticas (imagens digitais), as animações $e$ as simulações. $O$ uso de representações no ensino de ciências é algo comum e traz benefícios à compreensão de um determinado objeto de estudo que esteja inacessível, seja pelas suas dimensões, pelas condições necessárias para que seja observado, como 
um tempo demasiadamente curto ou longo, ou pelos custos envolvidos, como o caso de fenômenos que só podem ser reproduzidos com o uso de equipamentos caros. Contudo, é certo que uma representação não é um correspondente do objeto de estudo em toda a sua integridade, e a relação que ela possui com o que representa é sempre uma relação de analogia. Características são privilegiadas e outras descartadas ao se propor uma representação. Com isso, abre-se espaço para a interpretação inadequada e inesperada da representação, por exemplo, em que aspectos não relevantes na relação analógica são encarados como relevantes.

Em outras palavras, o pensamento, no ato de conhecer, isto é, na construção de um modelo mental sobre o que se estuda, pode se firmar em elementos da analogia que não permitiriam ou prejudicariam uma progressão ou aperfeiçoamento do modelo mental, resultando em uma não aproximação ao modelo conceitual alvo.

Para melhor compreendermos o papel das analogias e representações (análogos) na construção de conhecimento científico, lançamos mão mais uma vez das ideias de Bachelard. Em seu livro "La Formation de l'esprit scientifique: contribution à une psychanalyse de la connaissance" publicado em 1938, ele discute o papel das analogias, metáforas e da imagem no desenvolvimento da ciência (BACHELARD, 1996). Ainda que Bachelard não se detenha em caracterizar o que ele considera como imagens, analogias e metáforas, pelo que ele expõe e em uma aproximação ao que discutirmos até aqui na apresentação de nosso marco teórico, entendemos que ele se refere à imagem como uma representação; e às analogias e metáforas como as relações que se dão entre a imagem e o objeto que se deseja estudar ou discutir. Em outras palavras, não vemos prejuízos em considerar o termo "imagem" enunciado por Bachelard como a representação que se utiliza para que, mediante uma relação analógica ou metafórica, se compreenda um determinado alvo de estudo. Ele não apresenta uma distinção entre as analogias e as metáforas, mas seu argumento se constrói de forma notável a partir de uma análise destes dois tipos de comparações que o, por ele chamado, "espírito científico" estabelece com o intuito de conhecer. A falta de distinção, no entanto, não prejudica a apresentação de suas ideias.

Em nosso estudo, entretanto, distinguimos qualitativamente estas noções, de forma a melhor apresentar as nossas descrições e análises. Por isso, nos 
dedicamos a apresentar uma distinção entre analogias e metáforas no subcapítulo 3.1 apresentado anteriormente. Conforme expusemos, entendemos o uso das imagens estáticas, das animações e das simulações como um uso em que se estabelecem relações de analogias, já que os elementos visuais, de certa forma, explicitam o que se compara. No entanto, vale destacar que o uso destes recursos pode, também, vir acompanhado de explicações que explorem metáforas. Assim, seria útil para melhor compreender a situação de ensino e aprendizagem, estender o olhar também sobre as metáforas que porventura sejam utilizadas.

Bachelard defende que "o espírito científico deve lutar sempre contra as imagens, contra as analogias, contra as metáforas" (BACHELARD, 1996, p.48). Vale ressaltar, no entanto, que Bachelard não está condenando o uso das imagens, analogias e metáforas. Conforme afirma Lopes (1993a):

Não podemos [...] considerar que Bachelard defende a impossibilidade de
utilização de metáforas e imagens. [...] sua posição é de que a razão não se
pode acomodar a elas, devendo estar pronta a desconstruí-las sempre que
o processo de construção do conhecimento científico assim o exigir (Lopes,
1993a, p.163).

Em outras palavras, Bachelard aceita a utilização científica das imagens, analogias e metáforas, mas lhe conferem um caráter efêmero, que devem conduzir a formas mais estruturadas do pensamento, e para isso, é necessária a desconstrução destes recursos, ou seja, é necessário um olhar crítico que leve a perceber as limitações e contrastes da analogia ou da metáfora. A representação deve servir de conexão ao conhecimento que se deseja que seja aprendido, e não ocupar o lugar deste.

Indo além e estabelecendo algumas relações com as noções de modelos que comentamos anteriormente, podemos afirmar que construir conhecimento a partir da representação, alcançando uma proximidade com um modelo conceitual, só é de fato possível se a razão não se prende restritamente à representação, mas a desconstrói fazendo uso dos elementos úteis desta. $E$ reconhecer os elementos úteis depende de assumir uma postura crítica fundamental, em que se compreenda a representação não como algo mais do que ela é: um aparato útil, mas que não se assemelha integralmente a um alvo que se deseja conhecer. Assim, ao afirmarmos que a razão não pode se acomodar à representação, entendemos que a razão não deve ver o análogo como algo a mais do que uma representação incompleta do alvo. 
Entendemos que, de certa forma, é a falta de uma perspectiva crítica no uso das representações, seja por parte de quem a apresenta, mas principalmente por parte de quem as utiliza e as "absorve", que o seu uso pode se constituir em um problema. Uma postura crítica é necessária não somente para analisar a representação durante seu uso, mas também para investigar o próprio conhecimento já constituído, de forma que os hábitos do pensamento próprios deste conhecimento possam ser questionados a fim de superá-lo.

Em nosso marco teórico aproximamos as ideias de Bachelard ao estudo sobre modelos. Adotamos a definição de aprendizagem como uma evolução de modelos mentais se aproximando de um modelo conceitual alvo (CLEMENT, 2000), e reconhecemos o uso das representações como um meio de promover esta aproximação. Assim, entendemos que o modelo conceitual alvo, que quando provém da Física Moderna e Contemporânea é um conhecimento fenomenotécnico, pode ser alcançado em uma construção mediante o uso das representações.

Uma vez que, conforme definimos, o uso da representação é uma situação de analogia, para melhor compreender a relação entre modelos e analogias, tornamse úteis as ideias expostas por Duit (1991). O autor trata especificamente da formação de modelos a partir da relação analógica. Na Figura 6, que apresentamos no item 4.2.1, e na Figura 7 que será apresentada mais à frente, integramos as ideias de Duit (1991) ao esquema que representa o processo de aprendizagem mediante o uso de relações de analogia.

Elencamos ainda como parte do nosso marco teórico, as ideias sobre obstáculos epistemológicos de Bachelard, assim como sua adequação por Brousseau. Em uma aproximação à noção de modelos e assumindo uma perspectiva mais cognitivista, afirmamos que os obstáculos epistemológicos atuam nos instantes em que se tenta avançar de um modelo mental para outro que seja mais adequado. Vale ressaltar, no entanto, o cuidado que temos em não dar exclusiva atenção aos processos mentais, algo alvo de críticas aos trabalhos exclusivamente cognitivos. Primeiro, considerando como um meio possível para a identificação dos obstáculos epistemológicos, damos especial atenção à externalização dos modelos mentais por qualquer representação ou conjunto de ideias mais estruturadas, o que chamamos anteriormente de modelos expressos. $\mathrm{E}$ segundo, entendemos que a superação dos obstáculos ocorre principalmente 
mediante a argumentação dialógica que pode se estabelecer no contexto de ensino e aprendizagem. Das ideias de Brousseau, também nos é útil a noção de obstáculo didático. Reconhecemos a pertinência deste tipo de obstáculo em processos de ensino-aprendizagem, e desde um entendimento mais amplo do papel e da ação do professor, o redefinimos como obstáculo didático-pedagógico. Em uma compreensão inter-relacionada dos obstáculos, sugerimos também que os obstáculos didático-pedagógicos podem reforçar ou facilitar a emersão dos obstáculos epistemológicos. Ou seja, as escolhas inadequadas ou pouco adequadas do professor, que em alguns casos refletem ações comuns na prática docente, podem colaborar para que conhecimentos que deveriam ser superados sejam empregados na explicação e interpretação do que é novo.

Na Figura 6 que apresentamos no item 4.2.1 e na Figura 7, apresentada a seguir, buscamos representar as relações de analogia em meio a um processo de aprendizagem definido como uma evolução de modelos mentais. Conforme indicado na Figura 7, podemos situar os obstáculos epistemológicos como atuando no intervalo entre dois modelos mentais, por exemplo, entre M1 e M2. Os obstáculos epistemológicos poderão estar relacionados com quaisquer conhecimentos integrantes de um modelo mental anterior, independente do estágio em que se esteja durante a aproximação ao modelo conceitual, e podem tornar-se evidentes pela externalização dos alunos, que nas Figuras 6 e 7 estão representadas pelas linhas de cor azul e verde. Já os obstáculos didático-pedagógicos, que se manifestam especialmente na ação didática do professor, situam-se na dimensão do ensino. Assim, conforme indicado na Figura 7, a atuação destes obstáculos ocorre tanto na própria ação didática do professor como na dinâmica interativa da sala de aula, e como consequência, influencia o processo de evolução de modelos mentais dos alunos, podendo inclusive, como já dito, facilitar a emersão de obstáculos epistemológicos ou reforçá-los. 


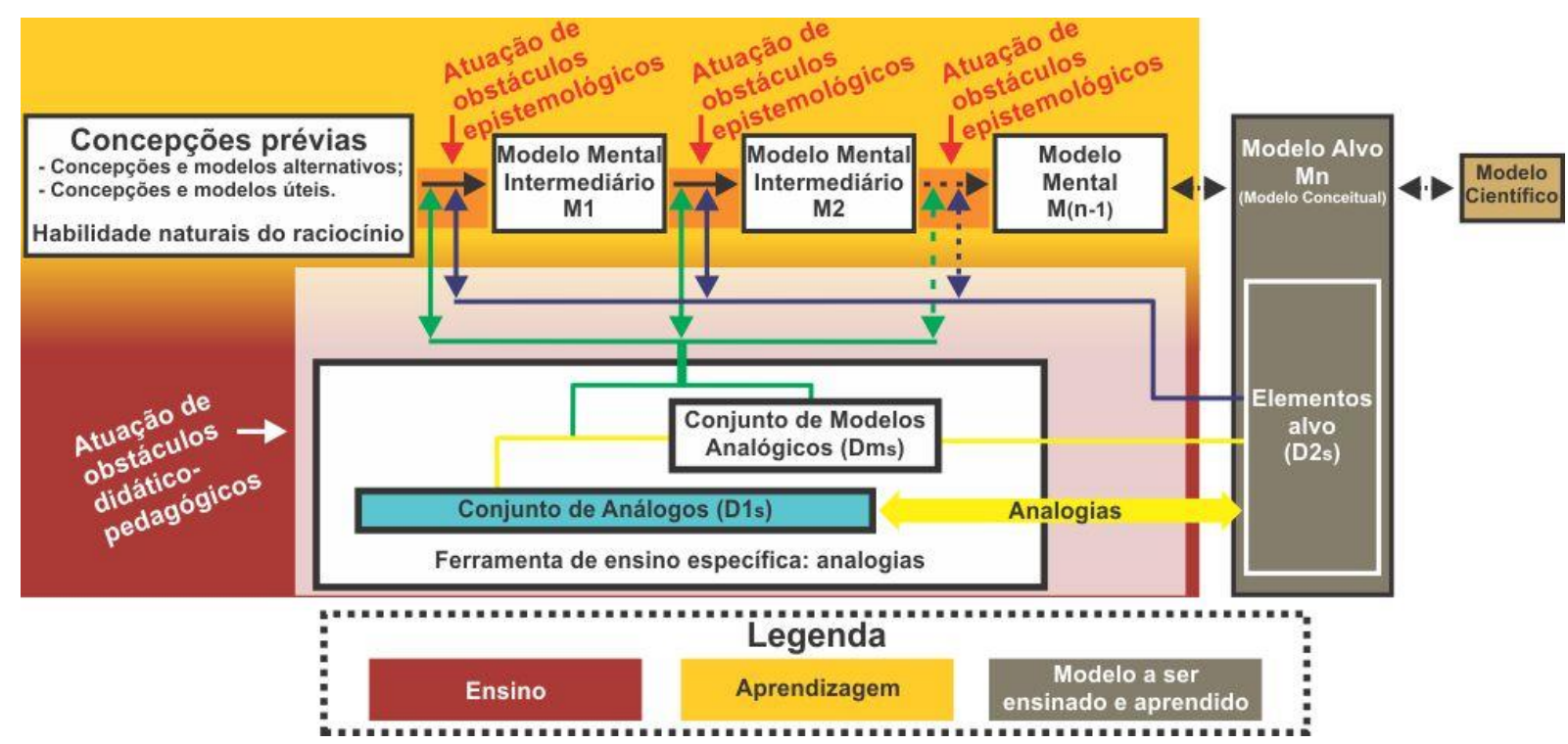

Figura 7. Representação do processo de ensino-aprendizagem mediado por analogias e a atuação de obstáculos epistemológicos e didático-pedagógicos.

Por fim, cabe destacar duas ideias que compõem o marco teórico e que também são muito relevantes nesta pesquisa, estando envolvidas no desenho do curso sobre a estrutura da matéria que é o pano de fundo da pesquisa: a modelização no ensino de ciências e a noção de ruptura de Bachelard.

Das abordagens sobre modelos no ensino de ciências que apresentamos, nos é útil não somente a ideia de aprendizagem como evolução de modelos mentais, mas também a noção de aprendizagem científica mediante a modelização. Ou seja, entendemos que é relevante a compreensão da aprendizagem desde a perspectiva dos modelos, mas também aceitamos que uma aprendizagem científica mais efetiva, ou mais autêntica, é aquela em que os alunos propõem e testam modelos. Acreditamos que a modelização no processo de ensino-aprendizagem, em que os alunos analisam, propõem e testam modelos é uma eficiente maneira de se reconhecer possíveis rupturas e inadequações de algo já conhecido. A modelização permite que se perceba, por exemplo, que um conhecimento válido para explicar algo, pode se mostrar insuficiente para explicar novos elementos ou pode se opor aos novos elementos.

Isto se mostra importante especialmente quando se considera a ideia de que a ciência é composta por conhecimentos aproximados, envolvendo rupturas, e que seu progresso implica em um "aproximar-se" de uma realidade. A partir da modelização, coloca-se em cheque, por exemplo, falsas noções sobre a natureza da ciência que são herdadas especialmente do pensamento positivista, em que se 
entende a ciência como fonte de conhecimentos seguros que vão se acumulando com o tempo; enquanto de fato ela é uma construção humana que funciona baseando-se nas dúvidas, na busca por respostas e na elaboração de novas perguntas.

A modelização é uma oportunidade de superar a acomodação de uma aprendizagem em ciências mais continuísta, em que conteúdos são apresentados como se a aprendizagem ocorresse por acúmulo de conhecimento e não por construções em que o que se conhece é relevante e pode se opor ao que se irá conhecer. Uma visão de aprendizagem continuísta por acúmulo de conhecimento é negar as construções e desconstruções que levam a um resultado de aprendizagem, é negar as idas e vindas da razão quando se evidenciam as rupturas. O conhecimento construído não é sinônimo de conhecimento acumulado, ele terá seu sentido definido não somente no instante do conhecer, mas também na continuidade do conhecer: esse conhecimento construído será mais que um alicerce tradicional para as novas aprendizagens, será um alicerce que poderá ser reedificado e reinterpretado sempre que $o$ ato de conhecer exigir. A modelização é uma forma de oportunizar isso. 


\section{PARTE III - DESENVOLVIMENTO DA PESQUISA}

Nesta seção, descrevemos o desenvolvimento da pesquisa. No capítulo 7 detalhamos as etapas percorridas, os métodos empregados e os contextos envolvidos. No capítulo 8 nos dedicamos a apresentar de forma detalhada o processo de elaboração e aplicação do curso sobre estrutura da matéria e aceleradores de partículas, o qual compôs o pano de fundo de nosso estudo.

\section{7- CONTEXTOS, ETAPAS E MÉTODOS}

Como nosso foco de estudo está na aprendizagem de conceitos de Física Moderna e Contemporânea mediada por recursos computacionais específicos, e como não estamos em uma perspectiva cognitivista exclusiva do estudo dos modelos mentais, e nem mesmo em uma perspectiva epistemológica exclusiva sobre o conhecer no ensino de ciências ou sobre o conteúdo científico em si, nos interessava lidar com contextos de aprendizagem que se assemelham aos ambientes formais de ensino, ou seja, que estejam próximos ao contexto de sala de aula. Assim, a pesquisa contou com a participação de alunos da Educação Secundária, em um curso que abordava tópicos específicos de Física Moderna e Contemporânea.

No subcapítulo 7.1, a seguir, descrevemos os contextos nos quais o curso foi desenhado e aplicado, com uma breve descrição dos participantes da pesquisa. Já no subcapítulo 7.2, apresentamos as etapas que foram percorridas no desenvolvimento da pesquisa, e descrevemos os instrumentos de coleta e análise de dados.

\section{1- Contextos da pesquisa}

A partir de uma parceria entre o Núcleo de Pesquisas em Inovação Curricular da Faculdade de Educação da Universidade de São Paulo (NUPIC/FEUSP) e o Centre de Recerca per a l'Educació Científica i Matemàtica da Universitat Autònoma de Barcelona (CRECIM/UAB) $)^{24}$, instituição localizada na

\footnotetext{
${ }^{24} \mathrm{Em}$ português: Centro de pesquisa para a Educação Científica e Matemática da Universidade Autônoma de Barcelona.
} 
Comunidade Autônoma da Catalunha na Espanha ${ }^{25}$, definiu-se um protocolo de pesquisa conjunto envolvendo os contextos catalão e paulista. Pesquisas envolvendo o desenho e implementação de cursos sobre Física Moderna e Contemporânea vêm sendo desenvolvidas no NUPIC/FEUSP desde 2003. Muitas parcerias foram estabelecidas com grupos estrangeiros que demonstram o interesse nos mesmos temas e se valem de metodologias de pesquisas semelhantes. Entre as linhas de pesquisa do CRECIM/UAB, estão aquelas que tratam do design e avaliação de sequências didáticas e envolvem estudos focados na sala de aula, e as que abordam a temática da inovação curricular, incluindo a inserção de tópicos de Física Moderna e Contemporânea na Educação Secundária (PINTÓ, 2005; PINTÓ; COUSO; GUTIERREZ, 2005; COUSO; PINTÓ, 2009; COUSO, 2011; COUSO et al., 2011). Assim, o CRECIM/UAB tem sido uma parceira preferencial para determinados estudos, como este que aqui apresentamos.

A pesquisa realizada em parceria com o CRECIM/UAB permitiu a implementação de um curso sobre FMC em dois contextos, curso este que possui partes de suas atividades centradas no uso de simulações computacionais. Além de contar com alunos e professores do ensino secundário paulista, ou seja, alunos do Ensino Médio do estado de São Paulo, a pesquisa contou com alunos e professores do ensino secundário catalão, denominado Bachillerato. O Bachillerato é uma etapa não obrigatória da Educação Secundária da Espanha, com dois anos de curso, que possui um caráter pré-universitário em que já há um direcionamento por área de interesse e dedicação futura aos estudos na educação universitária.

Os alunos que cursam o Bachillerato podem optar por uma de três áreas: Artes; Ciências e Tecnologias; ou Humanidades e Ciências Sociais (CATALUNYA, 2008). Assim como ocorre no currículo paulista para a disciplina de Física do Ensino Médio (SÃO PAULO, 2008), no currículo do curso de Ciências e Tecnologias do Bachillerato Catalão estão incluídos tópicos de Física Moderna e Contemporânea (CATALUNYA, 2008, p. 59263-59277).

\footnotetext{
${ }^{25}$ A Espanha possui uma divisão política e administrativa por Comunidades Autônomas. A Comunidade Autônoma da Catalunha se encontra no nordeste da Espanha, fazendo fronteira com Andorra e França e com o seu litoral banhado pelo mar mediterrâneo. E uma região com uma cultura bem específica, com duas línguas oficiais (o catalão, que para a grande maioria é a $1^{\text {a }}$ língua, e o castelhano) e com uma parcela significativa da população possuindo um sentimento nacionalista que, inclusive, tem levado muitos a integrar movimentos independentistas.
} 
O currículo de Física dos dois anos do Bachillerato em Ciências e Tecnologias se assemelha ao currículo previsto para os dois últimos anos do Ensino Médio paulista. Entre os tópicos previstos nos dois currículos, há aqueles que tratam da Estrutura da Matéria e das Partículas Elementares. O curso "De Thomson aos aceleradores de partículas", que serviu de pano de fundo em nossa pesquisa e que melhor descrevemos no capítulo 8, trata dos modelos atômicos e de uma introdução à Física de Partículas Elementares mediante uma discussão da técnica empregada nos aceleradores de partículas, e assim, contemplava alguns dos tópicos de FMC previstos em ambos os currículos.

Em ambos os contextos de desenho e implementação do curso (Catalunha e São Paulo), as situações de aula, ou seja, os momentos de implementação do curso desenhado, ocorreram nas próprias universidades em ambientes especialmente preparados para receber os alunos e com os recursos de infraestrutura necessários para a apresentação do curso e para a coleta dos dados que seriam posteriormente analisados.

Na Catalunha, o curso fez parte de um projeto denominado REVIR (RealitatVirtualitat) mantido pelo CRECIM/UAB ${ }^{26}$, o qual consiste em oferecer aos alunos e professores da Educação Secundária da Catalunha, sessões de trabalho experimental em um laboratório informatizado na própria universidade. Tais sessões são utilizadas como cenários para o desenvolvimento de investigações didáticas concretas, como é o caso da pesquisa que aqui apresentamos. Em São Paulo, o curso esteve relacionado aos projetos "O uso de simulações computacionais no ensino de física de partículas em nível médio"27 e "Inovação curricular em física: transposição didática de teorias modernas e a sobrevivência dos saberes" desenvolvidos pelo NUPIC/FEUSP e financiados pela Fundação de Amparo à Pesquisa do Estado de São Paulo (FAPESP). As implementações em São Paulo ocorreram na Faculdade de Educação da Universidade de São Paulo, em ambientes especialmente preparados para a realização do curso, que ofereciam os mesmos principais recursos utilizados no contexto catalão.

\footnotetext{
${ }^{26}$ Mais informações disponíveis em: <http://crecim.uab.cat/revir/>. Acesso em: 1 out. 2013.

${ }^{27}$ Mais informações disponíveis em: <http://www.bv.fapesp.br/pt/bolsas/140975/o-uso-de-simulacoescomputacionais-no-ensino-de-fisica-de-particulas-em-nivel-medio/>. Acesso em: 1 out. 2013.

${ }_{28}$ Mais informações disponíveis em: <http://www.bv.fapesp.br/pt/auxilios/6100/inovacao-curricularem-fisica-transposicao-didatica-de-teorias-modernas-e-a-sobrevivencia-dos-sabere/>. Acesso em: 1 out. 2013.
} 


\subsubsection{Participantes da pesquisa}

A pesquisa contou com a participação de professores de Física e alunos de ambos os contextos, catalão e paulista. Na Catalunha, quatro professores $\left(P_{0}, P_{1}\right.$, $\left.\mathrm{P}_{2}, \mathrm{P}_{3}\right)$ participaram dos momentos de implementação do curso e, destes, dois $\left(\mathrm{P}_{0} \mathrm{e}\right.$ $P_{1}$ ) estiveram envolvidos diretamente no desenho do curso definindo as atividades e as formas de abordar o conteúdo, e estiveram presentes nos momentos de redesenho do curso ocorridos na Catalunha. Em São Paulo, dois professores $\left(\mathrm{P}_{4} \mathrm{e}\right.$ $P_{5}$ ) participaram dos momentos de implementação do curso, sendo que um destes $\left(\mathrm{P}_{4}\right)$ esteve também envolvido em um dos momentos de redesenho do curso. Todos os professores participantes atuavam na Educação Secundária e participavam com frequência de projetos elaborados e executados pelos grupos de pesquisa (CRECIM/UAB e NUPIC/FEUSP) em suas respectivas regiões.

Nos momentos de implementação do curso, ou seja, nas situações de aula, havia sempre dois ou três professores participantes, entre os quais, um ficava responsável por guiar a aula. O professor responsável por essa função, além de ficar à disposição dos alunos quando estes realizavam as atividades, apresentava explicações para toda a turma, direcionava as discussões, enfim, administrava a aula. Os demais professores ficavam à disposição dos grupos de alunos e intervinham durante as explicações se julgassem necessário.

O curso foi aplicado quatro vezes no contexto catalão, incluindo uma implementação piloto, com a participação de em média de 30 alunos por aplicação, os quais estudavam em escolas de diferentes regiões da Catalunha, possuíam entre 16 e 17 anos de idade e cursavam o último ano do curso de Ciências e Tecnologias do Bachillerato. No contexto paulista, o curso foi aplicado em duas oportunidades, com uma média de 12 alunos por aplicação, que cursavam o último ano do Ensino Médio em escolas públicas da região metropolitana de São Paulo e possuíam entre 16 e 18 anos de idade. A participação dos alunos ocorria a partir de convites realizados em escolas da região em que se realizava a pesquisa (Catalunha e São Paulo). Após o convite, havendo a manifestação de interesse da escola, de alunos de uma mesma turma, e do professor de Física da turma, era definida uma data para a aplicação do curso.

$\mathrm{Na}$ implementação do curso, os alunos participantes desenvolviam as atividades em grupos de três ou quatro integrantes. Para cada grupo de alunos 
havia um computador para acessar o roteiro hipertextual ${ }^{29}$ das atividades, que continha os textos, imagens, simulações e questões que compunham cada atividade, todos reunidos em um ambiente virtual. O conteúdo da versão final do roteiro hipertextual, incluindo as imagens e indicações das simulações, é apresentado no Material do Professor, disponível no Apêndice A.

Além de acessar o ambiente virtual, os alunos utilizavam um dossiê que reunia as questões que eram apresentadas nas atividades do curso. No dossiê, cada um dos alunos respondia os questionamentos propostos. A versão final do dossiê é apresentada no Apêndice B.

\section{2- Etapas da pesquisa}

A pesquisa foi desenvolvida em duas etapas principais, sendo uma dedicada a um processo iterativo de desenho e implementação do curso, no qual os dados da pesquisa foram coletados, e outra etapa dedicada exclusivamente à análise dos dados obtidos. Estas etapas são descritas nos itens 7.2.1 e 7.2.2, a seguir:

\subsubsection{Processo iterativo de desenho/redesenho e implementação do} curso

Por algum tempo a pesquisa em educação em ciências, considerando aspectos mais cognitivos e teoricamente orientados (teorias de aprendizagem), concentrou-se em revelar concepções dos alunos sobre fenômenos e conceitos. Esta tendência, que com frequência é chamada de movimento das concepções espontâneas, trouxe contribuições significativas, mas mais restritas a perspectiva de aprendizagem centrada no aluno. Segundo Méheut e Psillos (2004), um pouco em consequência desses estudos empíricos, e considerando também os desenvolvimentos teóricos não somente restritos à aprendizagem, como também relacionados ao ensino, muitas pesquisas têm sido realizadas atualmente envolvendo atividades instrucionais e abordagens para melhorar a compreensão do conhecimento científico dos alunos, assim como compreender os processos didáticos que permeiam a implementação das atividades.

Neste novo cenário, destacam-se aquelas pesquisas baseadas no desenho didático e nas intervenções educacionais em geral, configurando uma grande linha

\footnotetext{
${ }^{29}$ Assumimos a definição para o termo hipertexto como sendo um texto digital que agrega recursos computacionais gráficos como imagens digitais, animações e simulações.
} 
de pesquisa conhecida como Design-Based Research (DBR). A linha DBR envolve o desenho e avaliação de intervenções de ensino (DESIGN-BASED RESEARCH COLLECTIVE, 2003). Estudos envolvendo aspectos de ensino e aprendizagem de tópicos específicos de ciências com base em um processo de desenho e implementação de conjuntos de atividades são chamados de Teaching-Learning Sequences (TLS) ${ }^{30}$ (MÉHEUT; PSILLOS, 2004). Um ponto de interseção entre alguns dos estudos dentro da linha DBR, e os estudos sobre TLS, é o fato de envolverem um processo iterativo (representado na Figura 8) em que há uma sequência bem definida de etapas que se sucedem de forma cíclica com o intuito de alcançar uma estabilidade didática condizente com os objetivos de aprendizagem pretendidos e com os resultados de investigação obtidos.

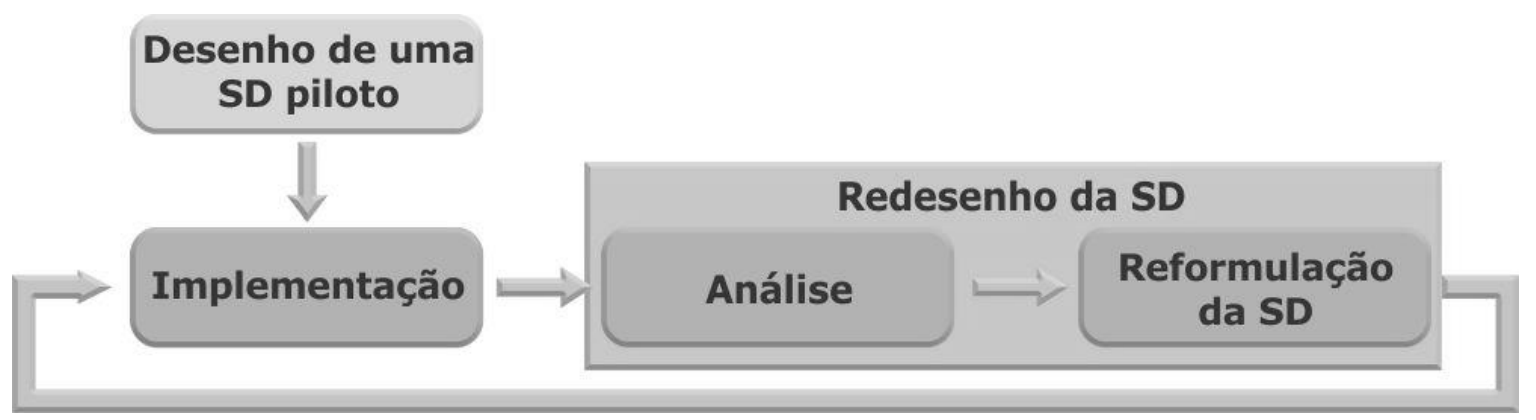

Figura 8. Representação do processo iterativo de desenho e implementação de sequências didáticas.

Uma sequência didática (SD) é inicialmente desenhada, gerando uma versão piloto a ser implementada em classe com alunos. Depois de implementada, com base nos resultados de aprendizagem e outros aspectos didáticos observados, é realizada uma análise que levará à reformulação da SD. $A S D$, uma vez reformulada, seguirá o processo cíclico de implementações e redesenhos. Este processo iterativo assume um papel metodológico importante em alguns estudos DBR e nos estudos envolvendo TLS. É um processo que permite uma maior profundidade no olhar sobre as boas práticas no ensino de tópicos específicos, em função dos resultados de aprendizagem.

Como o processo iterativo permite, enquanto método de pesquisa, o estudo aprofundado sobre o ensino e aprendizagem de temas de ciências específicos; vai ao encontro de algumas de nossas intenções de pesquisa sobre o ensino e aprendizagem de tópicos de Física Moderna e Contemporânea. A nossa pesquisa

\footnotetext{
${ }^{30}$ No capítulo 8 apresentamos algumas das características das TLS e indicamos quais foram consideradas no desenho do curso envolvido em nosso estudo.
} 
envolveu o desenho, implementações e redesenhos de um curso segundo um processo iterativo, semelhante àquele executado na linha DBR e nos estudos envolvendo TLS. No entanto, não consideramos nossa pesquisa como um estudo sobre TLS, e tão pouco seria um estudo com todas as características de uma DBR.

Enquanto o processo iterativo na linha DBR, e empregado nos estudos sobre TLS, está envolvido de forma global na execução da pesquisa buscando, entre outras coisas, efetuar uma validação do design de uma sequência didática, em nosso estudo o processo iterativo ocupa uma etapa da pesquisa, que serviu restritamente como pano de fundo para a tomada de dados que seriam posteriormente analisados em uma segunda etapa da pesquisa.

O principal ponto que diferencia as linhas DBR e TLS de nossa pesquisa reside na análise dos dados. Enquanto nestas linhas o momento de análise dos dados coincide com o momento de análise da SD dentro do processo iterativo (que faz parte do processo de redesenho da SD, como apresentado na Figura 8), em nosso estudo tal momento do processo iterativo serviu para uma pré-análise didática, que gerou observações que foram registradas em um caderno de campo, que em seguida foi utilizado como uma das fontes de dados, alvo de uma análise aprofundada em uma etapa posterior da pesquisa. Em outras palavras, em nossa pesquisa a análise realizada no redesenho do curso não corresponde à etapa de análise como em estudos de DBR e TLS, mas sim como um momento em que os dados foram coletados.

Esta diferenciação é importante, pois implica na não validação da versão final do desenho do curso implementado. Embora se possa dizer que o desenho do curso contém diversos elementos que o fazem um bom material didático ${ }^{31}$ para 0 ensino de tópicos de estrutura da matéria, não podemos dizer que ele tenha sido validado pela pesquisa didática.

Reconhecemos que o processo iterativo possui um potencial metodológico grande, compondo a própria estrutura da pesquisa em estudos ancorados na linha de investigação DBR e envolvendo TLS. No entanto, em nossa pesquisa o processo

\footnotetext{
${ }^{31}$ Conforme é apresentado no capítulo 8, o curso foi desenhado considerando alguns princípios de design. Além disso, o processo iterativo permitiu um aperfeiçoamento do desenho do curso, em que os redesenhos eram feitos considerando as expectativas e os resultados de aprendizagem, e com um olhar sobre o impacto das estratégias e recursos empregados. É neste sentido que afirmamos que o curso possui diversos elementos que o fazem um bom material didático.
} 
iterativo ocupou um papel mais discreto, compondo uma etapa da pesquisa e relacionado restritamente ao método de desenvolvimento e aplicação do curso, e não ao método da pesquisa de forma mais geral.

O processo iterativo ocorreu de forma contínua envolvendo os contextos catalão e paulista. Foi iniciado no contexto catalão, contando com quatro momentos de implementação do curso com alunos e quatro momentos desenho/redesenhos do curso, o que incluiu o desenho da versão piloto do curso e a sua implementação. A execução da pesquisa envolvendo o contexto catalão ocorreu principalmente ao longo do ano de 2012. Após a última implementação no contexto catalão, a última versão do curso passou por um redesenho que, além de efetuar ajustes necessários em função das observações na análise didática (pré-análise), contou com a adequação para a sua aplicação no contexto paulista.

Conforme já comentamos, há uma proximidade entre os conteúdos de Física Moderna e Contemporânea previstos no currículo da Comunidade Autônoma da Catalunha (CATALUNYA, 2008, p. 59263-59277) e no currículo do estado de São Paulo (SÃO PAULO, 2008), de forma que não foram efetuadas mudanças dos conteúdos físicos. Assim, a adequação consistiu na tradução dos materiais (roteiro hipertextual, dossiê dos alunos e manual do professor) do idioma catalão para o português, e na modificação de uma das atividades que se baseava na discussão do acelerador de partículas ALBA, instalado na Catalunha, substituindo por uma discussão sobre o acelerador de partículas Pelletron, localizado na Universidade de São Paulo. Ocorreram duas implementações no contexto paulista, todas no ano de 2013. Entre as implementações no contexto paulista, também ocorreram momentos de redesenho do curso, em que pequenas alterações no material disponível aos alunos e no roteiro de atividades foram realizadas.

O quadro 1, a seguir, apresenta uma síntese do processo iterativo iniciado no contexto catalão e encerrado no contexto paulista: 


\begin{tabular}{|c|c|c|}
\hline Momento & Contexto & Período de realização \\
\hline Desenho Piloto $\left(\mathrm{DS}_{0}\right)$ & Catalunha & Outubro à Dezembro de 2011 \\
\hline 1a Implementação - Piloto $\left(I_{1}\right)$ & Catalunha & Janeiro de 2012 \\
\hline 1ํ Redesenho $\left(\mathrm{DS}_{1}\right)$ & Catalunha & Fevereiro de 2012 \\
\hline $2^{\mathrm{a}}$ Implementação $\left(\mathrm{I}_{2}\right)$ & Catalunha & Março de 2012 \\
\hline 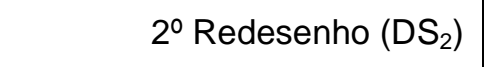 & Catalunha & Abril à Julho de 2012 \\
\hline $3^{a}$ Implementação $\left(I_{3}\right)$ & Catalunha & Novembro de 2012 \\
\hline 3ํㅡ Redesenho $\left(\mathrm{DS}_{3}\right)$ & Catalunha & Novembro de 2012 \\
\hline 4⿳亠口冋 Implementação $\left(I_{4}\right)$ & Catalunha & Novembro de 2012 \\
\hline $4^{\circ}$ Redesenho $\left(\mathrm{DS}_{4}\right)$ & Catalunha/São Paulo & Dezembro de 2012 à Abril de 2013 \\
\hline 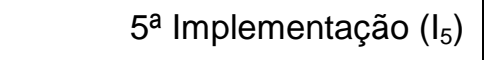 & São Paulo & Junho de 2013 \\
\hline $5^{\circ}$ Redesenho $\left(\mathrm{DS}_{5}\right)$ & São Paulo & Junho de 2013 \\
\hline 6aㅗ Implementação $\left(\mathrm{I}_{6}\right)$ & São Paulo & Junho de 2013 \\
\hline
\end{tabular}

Quadro 1. Etapas do processo iterativo de desenho e implementação do curso.

\subsubsection{Análise dos dados}

Durante os momentos de desenho/redesenho e implementação do curso, dados foram coletados, os quais foram posteriormente analisados em uma segunda etapa da pesquisa. Isto ocorreu segundo os objetivos que nortearam o estudo e estão relacionados ao reconhecimento de obstáculos epistemológicos e didáticopedagógicos relevantes em termos de ensino e aprendizagem.

\section{$\underline{\text { Instrumentos de coleta de dados e análise }}$}

Como instrumentos de coleta de dados foram utilizados uma câmera filmadora, gravadores de áudio, os dossiês preenchidos pelos alunos, e um caderno de campo. Enquanto a câmera captava imagens das situações de ensino e aprendizagem, os gravadores de áudio permitiam uma captação dos diálogos que ocorriam entre os integrantes dos grupos de alunos e professores.

As gravações de som e imagem foram operadas de forma a reduzir aspectos que pudessem interferir na fidedignidade da coleta de dados. Segundo Belei et al. (2008), as gravações em vídeo permitem um grau de exatidão na coleta dos dados de pesquisa, os quais podem servir de "... comprovação frente aos tradicionais 
questionamentos da subjetividade da pesquisa qualitativa”. Além disso, as gravações permitiram um olhar diferenciado nas análises, de forma que estas não se restringiram às observações que resultavam da imersão do pesquisador nas situações de ensino e aprendizagem.

Já o caderno de campo possibilitou o registro de observações da situação de ensino e aprendizagem e sobre aspectos didáticos que eram considerados durante os momentos de redesenho do curso. Este registro, que se baseava no ponto de vista do pesquisador, se apresentou como especialmente útil na interpretação dos demais dados registrados durante a última etapa da pesquisa, que envolveu a análise dos dados.

Além destes instrumentos, como ao longo das sessões do curso os alunos efetuavam também atividades na forma de questionários abertos, por meio dos dossiês a eles disponibilizados, estes também foram considerados na interpretação dos dados, em específico, na interpretação de diálogos que faziam referência direta a desenhos e esquemas elaborados pelos alunos em resposta ao solicitado nas questões propostas.

\section{$\underline{\text { A análise dos dados }}$}

Neste estudo, consideramos que os obstáculos epistemológicos, e principalmente a superação destes, além de outros diversos elementos importantes no uso das simulações computacionais e dos demais recursos computacionais envolvidos, se evidenciam nos diálogos que ocorrem nas situações de aprendizagem, seja por meio da expressão oral, como também por meio de outras expressões representativas. Assim, a gravação de áudio e vídeo nos forneceu alguns dos principais dados para nossa análise, sendo que os dados registrados no caderno de campo e os dados obtidos com os dossiês preenchidos pelos alunos ocuparam um papel auxiliar facilitando a interpretação dos dados coletados por áudio e vídeo.

Como o nosso estudo possui um caráter qualitativo e interpretativo, a análise dos dados consistiu na identificação e categorização dos obstáculos epistemológicos registrados e/ou observados nas sessões, e em sua associação com aspectos de aprendizagem e verificação de possíveis relações com obstáculos didáticopedagógicos. Segundo o referencial teórico que assumimos em nosso estudo, em 
especial a relação entre os erros conceituais que são apresentados pelos alunos e a possível atuação de obstáculos de aprendizagem, como descritos por Brousseau em sua teoria das situações didáticas, buscamos inicialmente identificar os erros conceituais apresentados pelos alunos nas situações de aula, isto é, nos momentos de implementação do curso. Esta identificação constituiu-se em um momento de seleção de dados que antecedeu a análise dos dados.

Para facilitar a análise dos dados, foram transcritas as situações em que eram apresentados os erros conceituais, e que em um primeiro olhar teria revelado a possível atuação dos obstáculos. No caso das situações que ocorreram no contexto catalão, a transcrição ocorreu diretamente na língua portuguesa, ou seja, envolveu uma ação simultânea de tradução e transcrição dos diálogos. Além da transcrição dos diálogos, possíveis desenhos e esquemas elaborados pelos alunos no quadro negro e nos dossiês, que de alguma forma estavam envolvidos nos diálogos, também foram considerados: os desenhos registrados nos registros em vídeo foram capturados na forma de imagem e os desenhos presentes no dossiê foram digitalizados. Assim, os dados efetivamente analisados na pesquisa foram principalmente textuais (transcrições dos diálogos), mas quando necessário também se recorreu às imagens (esquemas e desenhos elaborados pelos alunos) e, como já comentado, às observações registradas no caderno de campo.

$\mathrm{Na}$ análise, se buscou identificar de que forma os erros estavam associados aos obstáculos epistemológicos, de que forma estes influenciavam a aprendizagem mediada pelo uso das simulações computacionais, e de que forma possíveis obstáculos didático-pedagógicos teriam facilitado a emersão dos obstáculos epistemológicos. Os obstáculos epistemológicos foram classificados segundo uma tipologia inspirada na literatura, em especial o apresentado pelo filósofo da ciência Bachelard em sua obra "A formação do espírito científico". Também foi alvo de verificação durante a análise, a forma como os obstáculos eram superados. Ou seja, verificou-se a forma como instrumentos argumentativos e representativos foram utilizados pelos professores para auxiliar os alunos na superação dos obstáculos.

Para facilitar a análise qualitativa e interpretativa foi utilizado o software Atlas.ti (FRIESE, 2011). Trata-se de uma eficiente ferramenta para a análise qualitativa de grandes quantidades de textos, gráficos, dados de áudio e vídeo. O software foi uma importante ferramenta auxiliar na organização, gerenciamento e 
interpretação dos dados coletados, permitindo reunir trechos dos diálogos segundo o tipo de obstáculo epistemológico atuante, e permitindo uma comparação com os obstáculos didático-pedagógicos identificados.

A Figura 9, a seguir, apresenta um diagrama representativo do processo empregado na seleção e análise dos dados.

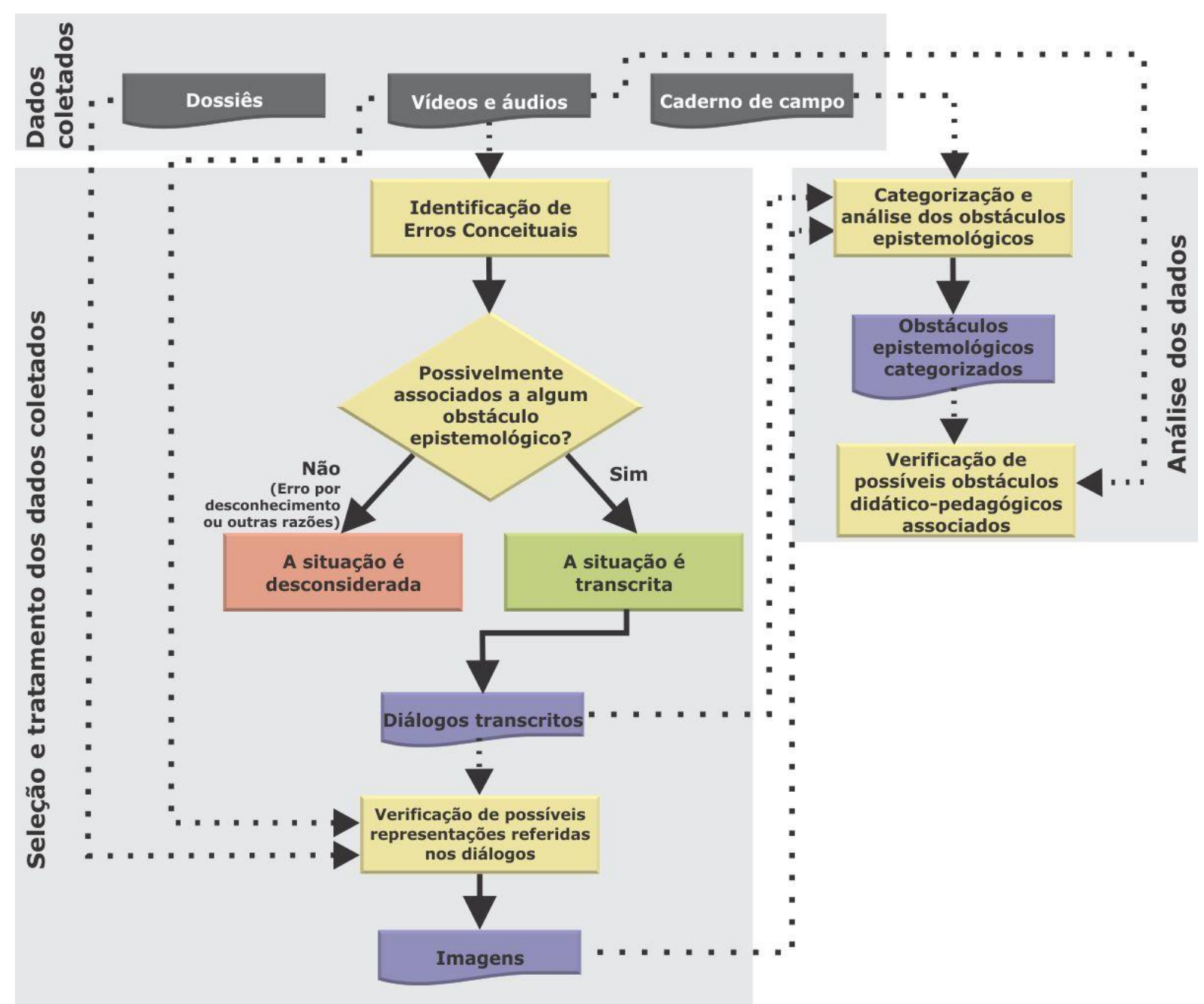

Figura 9. Processo de seleção e análise de dados. 


\section{8- O CURSO SOBRE ESTRUTURA DA MATÉRIA E ACELERADORES DE PARTÍCULAS}

Conforme já comentado, o curso sobre estrutura da matéria e aceleradores de partículas, que serviu de pano de fundo para o nosso estudo, foi desenhado e implementado em meio a um processo iterativo. Neste sentido, nos inspiramos em um método empregado em estudos da área DBR e nos estudos envolvendo TLS. Nossa inspiração nas linhas DBR e TLS não se restringiu, no entanto, ao método cíclico de produção e teste de um desenho didático. Outros aspectos foram considerados, especialmente aqueles relacionados ao desenho de TLS. No subcapítulo 8.1, a seguir, melhor definimos as TLS, apresentamos suas características principais, e destacamos quais aspectos foram considerados na elaboração do curso envolvido em nossa pesquisa.

\section{1- Desenho do curso: inspiração nos estudos sobre TLS}

Segundo Méheut e Psillos (2004), as chamadas Teaching-Learning Sequences (TLS) consistem em sequências didáticas desenhadas para tratar um tópico específico de ciências, e estruturadas para ser implementadas em um curto ou médio período de tempo. Diferentemente de desenhos curriculares de longo prazo, envolvendo vários meses ou anos, as TLS estão normalmente envolvidas em investigações mais restritas, em que um tema é estruturado para ser ensinado e aprendido em um bloco de aulas contidas em semanas ${ }^{32}$.

As TLS são planejadas de acordo com princípios de design que são escolhidos em função dos objetivos, da tradição, e dos recursos de pesquisa em que são desenvolvidas e implementadas. Segundo Méheut e Psillos (2004), as TLS produzidas no âmbito da tradição Developmental Research (LIJNSE, 1995), consideram aspectos mais cognitivos e tendem a ser elaboradas tomando como ponto central o papel do aluno, e secundariamente o papel do professor. Nas TLS produzidas na tradição de pesquisa Educational Reconstruction (KATTMANN et al., $1995^{33}$ apud MÉHEUT; PSILLOS, 2004), os aspectos cognitivos acabam ocupando

\footnotetext{
${ }^{32}$ Em geral, a maioria dos designs de TLS envolvem entre 8 e 10 aulas, que podem ser tratadas em no máximo 2 meses.

${ }^{33}$ KATTMANN, U.; DUIT, R.; GROPENGIEBER, H; KOMOREK, M. (1995) A model of Educational Reconstruction. Paper presented at The NARST annual meeting, San Francisco, CA.
} 
um papel mais secundário, valorizando-se aqueles aspectos relacionados com a motivação dos alunos e com as implicações sociais e éticas do conhecimento a ser ensinado. Já na Ingénierie Didactique (ARTIGUE, 1988), aspectos epistemológicos do conhecimento e aspectos psicocognitivos relacionados com as concepções prévias e científicas e com o raciocínio ganham evidência, mas também se considera a perspectiva didática relacionada com as limitações educacionais.

Daquilo apresentado por Méheut e Psillos (2004), podemos organizar os princípios de design em quatro grupos: (i) os princípios epistemológicos centrados no conteúdo a ser ensinado; (ii) os princípios psicocognitivos centrados na aprendizagem dos alunos; (iii) os princípios didáticos centrados na ação do professor; (iv) e os princípios socioculturais centrados nas interações que se dão em sala de aula e nas questões morais e éticas envolvidas. Tais princípios de design enfatizam, respectivamente, a natureza do conhecimento científico, como se aprende ciências, como se ensina ciências, e como as interações e aspectos sociais permeiam a situação de aula.

Não consideramos o desenho do curso envolvido em nossa pesquisa como um desenho de uma TLS, em especial, pelo fato do curso ser mais restrito a um pequeno número de atividades, com uma implementação prevista para ocorrer em uma única sessão de aula com 4 horas de duração, e não em um grupo de algumas aulas como em uma TLS tradicional. No entanto, assim como ocorre com o desenvolvimento de uma TLS, o curso foi elaborado segundo alguns princípios de design. Os princípios de design que definimos acima foram considerados na concepção do curso: (a) princípios epistemológicos no qual detemo-nos sobre o conhecimento de Física Moderna e Contemporânea, (b) princípios psicocognitivos nos quais assumimos uma noção de aprendizagem relacionada à ideia de modelos mentais, (c) princípios didáticos nos quais utilizamos estratégias de ensino baseado em modelização, e mais sucintamente, (d) princípios socioculturais nos quais damos valor aos modelos expressos por alunos e professores e às externalizações que se dão nos momentos de interação.

De maneira prática, cada um desses princípios moldou a forma como as atividades foram produzidas.

O princípio epistemológico se materializou na nossa adesão à interpretação bachelardiana do conhecimento da Física Moderna e Contemporânea onde não há 
fenômenos a estudar, mas fenomenotécnicas. Ou seja, a técnica no sentido amplo é fundamental no processo de compreensão e construção desse conhecimento científico. Desse modo, definiu-se que o curso, ao tratar dos conceitos físicos envolvidos nos aceleradores de partículas e sobre a estrutura do átomo, deveria possuir uma ênfase na discussão das técnicas presentes nessa área de estudo. Assim, valorizou-se no desenho do curso atividades que buscassem simular a técnica experimental e os conceitos a ela relacionados: em especial, a técnica de obtenção de informações de um objeto oculto e/ou inacessível por meio de sua interação com objetos visíveis ou "visualizáveis" por meio de detectores, presente, por exemplo, na observação de trajetórias. Esta técnica está presente tanto nos aceleradores de partículas como no experimento histórico de Geiger-Marsden, que permitiu a Rutherford reconhecer a inadequação do modelo atômico de Thomson e a propor um novo modelo atômico.

Em uma perspectiva epistemológica em que se considera o conhecimento científico sempre como uma aproximação, considerou-se no desenho do curso um sequenciamento de atividades que aos poucos aproximava noções mais diretamente perceptíveis àquelas envolvidas nos estudos sobre estrutura da matéria e aceleradores de partículas. Assim, no curso as primeiras atividades buscavam demonstrar a técnica a partir de uma atividade baseada em um experimento analógico que explorava a percepção mais direta e, posteriormente, a mesma técnica era discutida em atividades baseadas em uma simulação do experimento de Geiger-Marsden e, finalmente, se discutia aspectos físicos envolvidos nos aceleradores de partículas buscando responder, mediante a técnica, "O que são e como trabalham os aceleradores de partículas?".

Desde o princípio didático em que se entende que uma aprendizagem científica mais autêntica deve se basear em uma modelização (modelos científicos são estudados, testados e redefinidos), as atividades definidas no estudo da estrutura atômica envolveram uma discussão em que predições eram elaboradas com base no modelo atômico de Thomson. Em seguida, as predições eram testadas no experimento de Geiger-Marsden simulado, e não sendo confirmadas, poderiam levar à redefinição do modelo atômico, algo que de fato historicamente ocorreu. 
Vale destacar que o princípio didático da modelização e o princípio epistemológico estão relacionados, pois em ambos os casos se toma 0 conhecimento científico como aproximado. Os modelos científicos em estudo e em construção se aproximam mais ou menos de uma realidade acessível e tecnicamente construída. Ao mesmo tempo, estes princípios vão ao encontro com o princípio psicocognitivo no qual a aprendizagem é entendida como uma evolução de modelos mentais. É esperado que um processo de modelização esteja associado a esta evolução, e que culmine em um modelo mental semelhante/próximo ao modelo conceitual alvo.

Por fim, desde um princípio sociocultural, ainda que de forma menos pronunciada se comparado aos demais princípios, as atividades e a própria estrutura do curso foram elaboradas de modo a permitir um trabalho conjunto e interativo dos alunos e professores. Como entendemos que os modelos expressos pelos alunos podem evidenciar os possíveis erros conceituais que poderiam estar associados a obstáculos de aprendizagem, e como acreditamos que é principalmente na interação com o professor e com outros alunos que estes obstáculos de aprendizagem poderiam ser superados, as atividades do curso foram previstas para serem realizadas em grupo e com o auxílio dos professores. Além disso, na estrutura do curso são previstos momentos em que a turma toda deve discutir as respostas apresentados aos questionamentos e discutir os resultados obtidos com o uso das simulações e do experimento analógico utilizado.

Ao considerar no desenho do curso diferentes tipos de princípios de design que atuam de forma integrada, buscamos verificar os obstáculos à aprendizagem (epistemológicos e didático-pedagógicos) de conceitos de Física envolvidos na temática da estrutura matéria e dos aceleradores de partículas em situações de ensino com o uso de recursos computacionais. A seguir, no subcapítulo 8.2, apresentamos um detalhamento da estrutura do curso elaborado:

\section{2- Estrutura do curso}

O curso intitulado em sua versão final como "De Thomson aos aceleradores de partículas", em parte é dedicado a um estudo da estrutura da matéria mediante uma discussão sobre os modelos atômicos. Essa discussão baseia-se não somente nos conceitos, mas na técnica empregada e nos conhecimentos relacionados à 
técnica, e permite uma construção gradual de algumas noções envolvidas nos aceleradores de partículas. A discussão sobre os aceleradores de partículas, por sua vez, serve como uma introdução ao estudo das partículas elementares. Quadro 2 que se segue apresenta a estrutura do curso:

\section{I - Introdução / Motivação (25 minutos)}

1. Os Raios $X$ e o estudo sobre as doenças do coração: discute-se uma notícia sobre o uso de Raios $X$ produzidos por um acelerador de partículas em uma pesquisa, a qual revelou a estrutura de uma proteína utilizada em medicamentos que combatem níveis altos de colesterol. Com isso pretende-se motivar os alunos para o estudo sobre o interior e a estrutura da matéria e sobre os aceleradores de partículas;

2. Uma "fotografia" especial: a partir de uma comparação entre radiografias e fotografias, objetiva-se recapitular alguns conceitos de Física envolvidos no estudo do espectro eletromagnético, os quais serão úteis no decorrer do curso;

\section{II - Experimento Analógico (45 minutos)}

3. Outra maneira de "ver": é utilizado um experimento real em que os alunos devem descobrir o tamanho, a forma e detalhes de um objeto geométrico escondido sob um quadrado. Para isso, os alunos devem utilizar bolas de gude, lançá-las contra o objeto geométrico e inferir suas propriedades a partir da observação das trajetórias das bolas de gude. Com essa atividade é introduzida a técnica de obtenção de informações de algo desconhecido a partir de sua interação com o que se conhece, técnica esta que é empregada no experimento histórico de GeigerMarsden e, atualmente, nos aceleradores de partículas.

\section{Intervalo de 20 minutos}

\section{III - Estrutura do átomo (100 minutos)}

4. Modelo de Thomson: discute-se o modelo de Thomson e sua adequação em explicar a existência de elétrons no interior do átomo. É solicitado aos alunos que façam uma predição do que ocorreria com partículas com carga elétrica positiva (partículas alfa) que fossem lançadas contra um átomo, segundo o modelo de Thomson;

5. 0 espalhamento de Rutherford: o experimento histórico de Geiger-Marsden é apresentado e com o uso de uma simulação computacional deste, os alunos devem verificar suas predições. É esperado que os alunos reconheçam o modelo atômico de Thomson como inadequado para explicar os resultados "experimentais" obtidos na simulação. Espera-se também que os alunos reconheçam como mais adequada uma estrutura atômica envolvendo um núcleo positivo;

6. O átomo nuclear: discute-se o modelo atômico nuclear proposto por Rutherford e, com o uso de uma segunda simulação computacional, busca-se demonstrar sua adequação para explicar os resultados obtidos e, ao mesmo tempo, aprofundar o estudo da interação elétrica entre partículas alfa e núcleo atômico;

\section{IV - A técnica (25 minutos)}

7. Retorno ao experimento analógico: a atividade envolve uma comparação entre a técnica empregada no experimento histórico de Geiger-Marsden e no experimento real analógico realizado anteriormente. Na comparação, que pode ser feita com base no uso de uma terceira simulação, objetiva-se tornar claro as semelhanças e as diferenças existentes na técnica empregada, por exemplo, a interação elétrica atuante em um nível subatômico no experimento de Geiger-Marsden e a interação mecânica que ocorre em um nível macroscópico no experimento real;

\section{V - Aceleradores de Partículas (25 minutos)}

8. Os aceleradores de partículas: introduz-se a noção de aceleradores de partículas mediante a discussão da técnica e, após a leitura de um texto, solicita-se aos alunos que comparem a técnica empregada nos aceleradores e nos experimentos anteriores. A partir da leitura do texto e da comparação que é feita, espera-se que seja reconhecida a força magnética como aquela que permite a orientação de um feixe partículas no interior dos aceleradores, além da atuação da força elétrica como o que permite a aceleração do feixe;

9. LHC e o ALBA / Pelletron: finalizando o curso, os alunos comparam o acelerador de partículas LHC com um acelerador de partículas localizado próximo à região em que residem, o ALBA (Catalunha) ou o Pelletron (São Paulo).

Quadro 2. Estrutura geral do curso e tempo estimado para a realização de cada atividade. 
Conforme é apresentado no quadro 2, o design gerou uma estrutura de 5 etapas principais (que denominamos como "atividades"), com tempo de duração definidos, e cada qual possuindo um ou mais tópicos a serem tratados. O curso foi planejado definindo inicialmente uma discussão sobre o porquê de se tentar conhecer o interior da matéria. Em seguida, se introduz a discussão da técnica de obtenção de informações indiretamente, e em uma perspectiva histórica, se discute o modelo atômico de Thomson e sua superação a partir dos resultados do experimento de Geiger-Marsden analisados por Rutherford. Em seguida, é feita uma comparação entre a técnica empregada no experimento analógico e no experimento de Geiger-Marsden. Por fim, mediante a discussão da técnica, se introduz o tema dos aceleradores de partículas. A discussão aborda, além do Large Hadron Collider (LHC), outro acelerador de partículas existente na região em que ocorria a implementação: no contexto catalão foi utilizado como exemplo de acelerador de partículas o Síncroton $A L B A$, localizado na região da Catalunha em um campus da Universitat Autònoma de Barcelona; enquanto que no contexto paulista utilizou-se como exemplo o acelerador de partículas Pelletron localizado no Instituto de Física da Universidade de São Paulo (Campus Butantã). Esta estrutura geral apresentada se manteve inalterada durante o processo iterativo, sendo que as mudanças efetuadas foram apenas pontuais.

Conforme já comentamos, o curso em sua implementação na Catalunha ocorreu no contexto do projeto REVIR. Os cursos que ocorriam no projeto REVIR envolviam sessões únicas de 4 horas de duração, incluindo um intervalo de 20 minutos. Assim, o curso elaborado foi organizado considerando esta mesma duração de tempo.

Considerando a noção de modelo conceitual que compõe parte do referencial teórico que adotamos nesta pesquisa, a Figura 10 a seguir, apresenta um esquema da estrutura representada no Quadro 2, indicando as principais ideias que compõem o modelo conceitual alvo esperado, e os modelos parciais que se planeja que sejam percorridos no andamento do curso: 


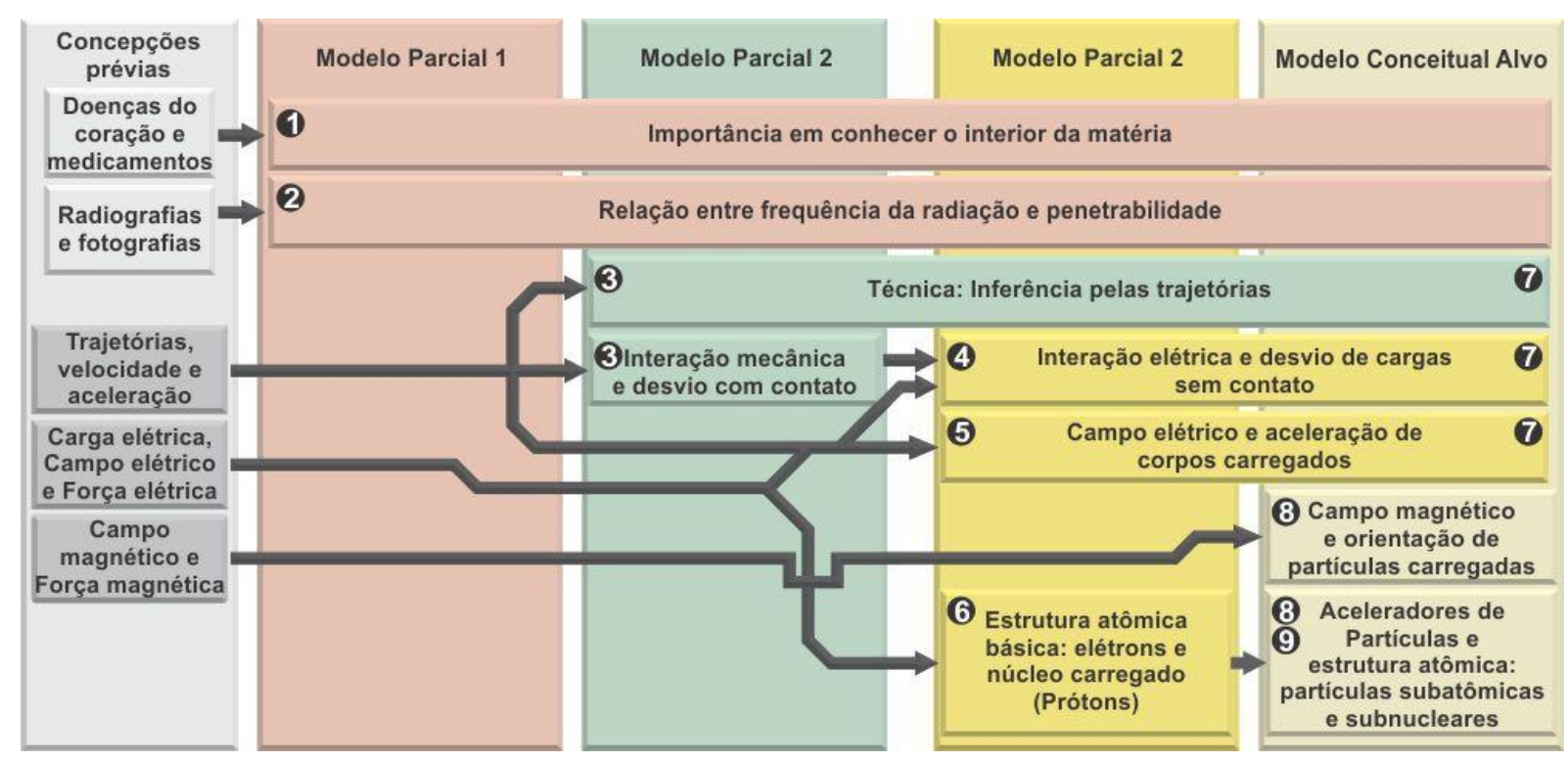

Figura 10. Esquema representativo dos modelos conceituais parciais e final envolvidos no curso.

$\mathrm{Na}$ Figura 10, enquanto as concepções prévias indicadas seriam aquelas que se imagina que os alunos já possuam integrando parte de seus modelos mentais, os modelos parciais são modelos conceituais temporários, definidos no planejamento do curso e que são percorridos para que seja alcançado o modelo conceitual alvo, que é o modelo conceitual que ao final se espera que seja aprendido/construído. As ideias e conceitos que aos poucos são inseridos possuem alguma relação com as concepções prévias (percepções do senso comum e conhecimentos de Física Clássica) que se espera que os alunos possuam ${ }^{34} \mathrm{e}$, aos poucos ao longo do curso, são apresentadas/construídas novas ideias e conceitos. Os modelos conceituais estão distribuídos em colunas coloridas, e dentro destas são indicadas as principais ideias ou conceitos que fazem parte de cada modelo conceitual. Aquelas ideias e conceitos que são parte de mais de um modelo conceitual são representados por retângulos que ultrapassam o limite das colunas, e suas cores coincidem com a cor do modelo conceitual que as introduziu no curso. Os números 1 a 9 indicam as etapas (partes de uma atividade), que são as mesmas numeradas de 1 a 9 no Quadro 2.

Um dos pilares do curso é a discussão da técnica, que inter-relaciona os variados conceitos e ideias que são abordados. Conforme se observa no Quadro 3,

\footnotetext{
${ }^{34} \mathrm{O}$ curso foi elaborado direcionado para alunos do $2^{\circ}$ ano do Bachillerato (Catalunha) e do $3^{\circ}$ ano do Ensino Médio (São Paulo), etapas da Educação Secundária em que se espera que os alunos, além de terem alguma noção mais superficial (senso comum) sobre as doenças coronárias e sobre radiografias e fotografias, já tenham estudado ou estejam estudando os temas de Física relacionados às interações mecânicas e eletromagnéticas.
} 
em uma aproximação parte-se da técnica empregada no experimento analógico, passando pela técnica empregada no experimento de Geiger-Marsden, chegando à técnica empregada nos aceleradores de partículas:

\begin{tabular}{|c|c|c|c|}
\cline { 2 - 4 } \multicolumn{1}{c|}{} & $\begin{array}{c}\text { Experimento } \\
\text { Analógico }\end{array}$ & $\begin{array}{c}\text { Experimento de } \\
\text { Geiger-Marsden }\end{array}$ & $\begin{array}{c}\text { Acelerador de } \\
\text { Partículas }\end{array}$ \\
\hline Projétil & Bolas de gude & Partículas alfa & Partículas subatômicas ou \\
Alvons
\end{tabular}

Quadro 3. Comparação de aspectos da técnica envolvida no experimento analógico, no experimento de Geiger-Marsden e nos aceleradores de partículas.

Uma descrição mais detalhada da estrutura final do curso é apresentada no Material do Professor disponível no Apêndice A. Nela há a indicação dos momentos de realização das atividades em grupo, dos momentos destinados à exposição do professor e dos momentos destinados à interação envolvendo toda a turma.

Em nossa pesquisa, nos interessa investigar a emersão de obstáculos de aprendizagem em situações de uso de simulações computacionais. Conforme podemos perceber na descrição da estrutura do curso apresentada no Quadro 2, mais da metade do tempo do curso envolve atividades que se baseiam no uso de três simulações computacionais. Assim, é principalmente nas situações de uso destas simulações que buscamos os dados que foram alvos de análise. A seguir apresentamos as três simulações computacionais utilizadas no curso e, também, alguns outros recursos computacionais gráficos que foram utilizados, os quais ocuparam um papel coadjuvante nas atividades.

\subsection{1- Recursos computacionais utilizados: ambientes virtuais,} simulações computacionais e imagens digitais dinâmicas e estáticas

Conforme comentamos brevemente ao final do Subcapítulo 7.1, os textos, simulações, imagens e outros recursos gráficos que faziam parte do curso estavam reunidos e poderiam ser acessados pelos alunos por meio de um ambiente virtual. Foi utilizado um ambiente virtual diferente para cada contexto, o catalão e o paulista, mas que possuíam semelhanças no layout. No contexto catalão, como o curso foi 
implementado dentro do projeto REVIR, o ambiente virtual utilizado foi o mesmo que se utilizava para todos os cursos oferecidos no projeto. Tal ambiente virtual possuía um link de acesso ao conteúdo de cada um dos cursos, incluindo o curso sobre estrutura da matéria e aceleradores de partículas. Já o ambiente virtual utilizado no contexto paulista foi desenvolvido especialmente para a execução da pesquisa, disponibilizando unicamente o conteúdo do curso. As Figuras 11 e 12, a seguir, apresentam respectivamente telas capturadas dos ambientes virtuais utilizados no contexto catalão e no contexto paulista:

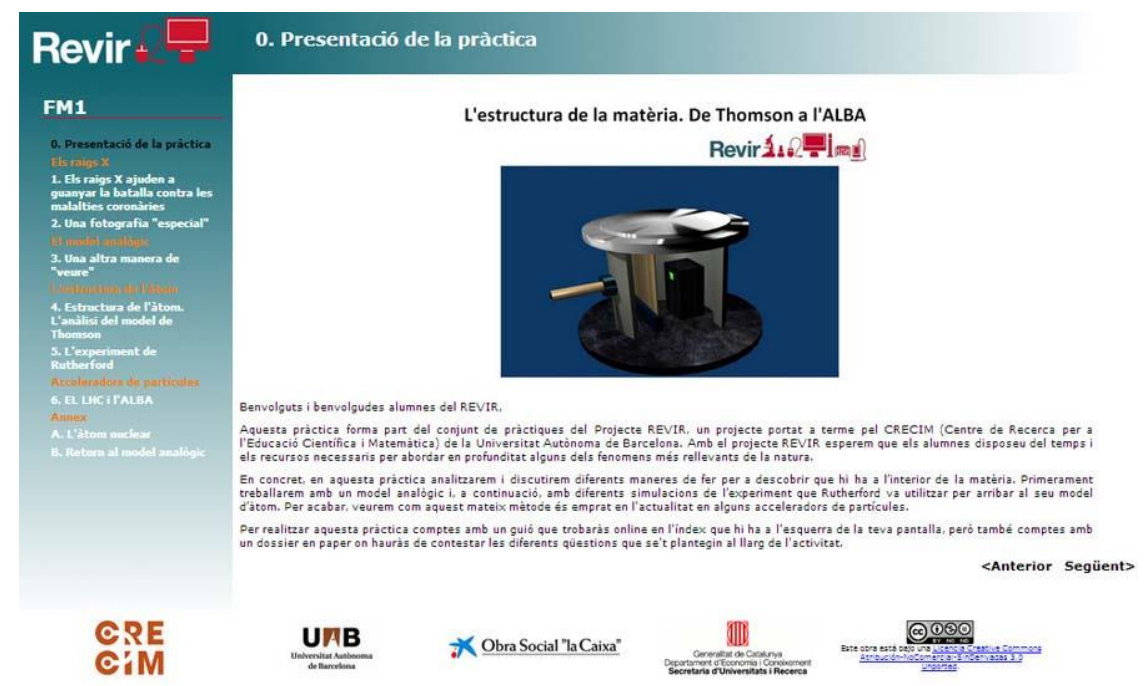

Figura 11. Tela capturada do ambiente virtual utilizado no contexto catalão. Ambiente virtual disponível em <http://crecim.uab.cat/revir/>. Acesso em: 1 out. 2013.

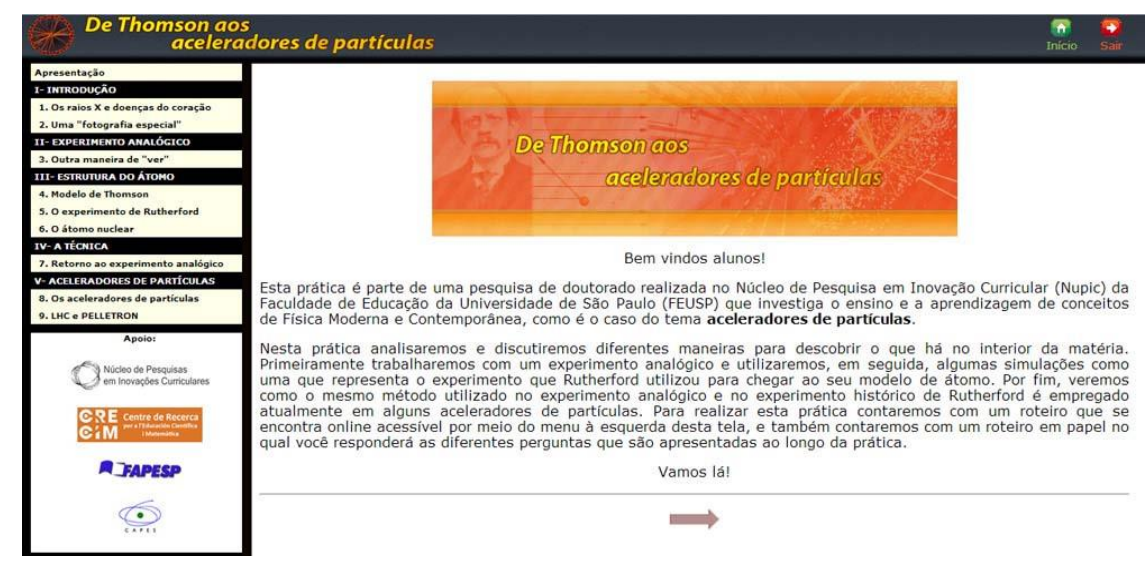

Figura 12. Tela capturada do ambiente virtual utilizado no contexto paulista. Ambiente virtual disponível em <http://www.aceleradores.hol.es/>. Acesso em: 1 out. 2013.

Em relação às simulações computacionais, foram utilizadas três, que foram escolhidas segundo os objetivos didáticos de apresentação e estudo dos modelos conceituais envolvidos no curso. As simulações computacionais selecionadas pertenciam ao The King's Centre for Visualization in Science, um centro de pesquisa 
do The King's University College, instituição canadense (KCVS, 2011), e estão disponíveis no website do mesmo.

A primeira simulação (KCVS, 2010a), que apresenta o título Rutherford Scattering, representa o experimento de Geiger-Marsden, e simula o lançamento de partículas alfa contra um anteparo. Entre as opções de configuração da simulação, é possível selecionar entre diferentes valores de energia para as partículas alfa, escolher entre quatro diferentes materiais para o anteparo e adicionar filtros para restringir a emissão de partículas alfa. Um visor virtual e móvel ao redor do anteparo possibilita identificar as partículas alfa que chegam a diferentes posições após desvios com diferentes ângulos. Uma imagem da tela capturada da simulação é apresentada na Figura 13, a seguir:

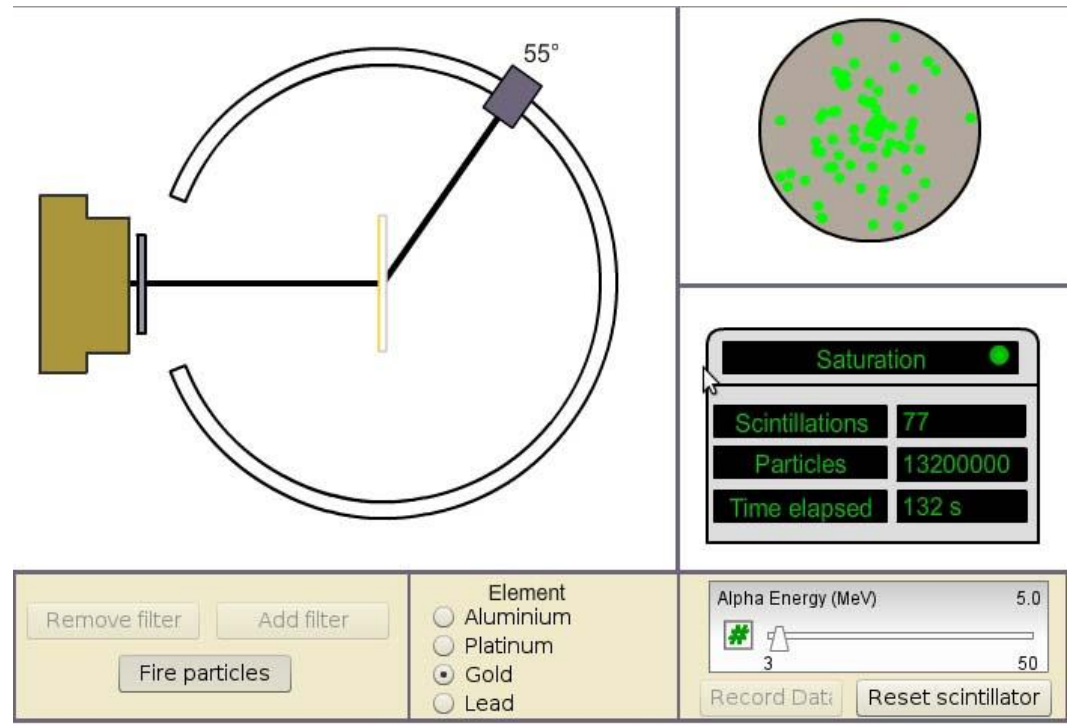

Figura 13. Tela capturada da simulação Rutherford Scattering que representa o experimento de Geiger-Marsden. Simulação disponível em <http://www.kcvs.ca/site/projects/physics_files/rutherford/historical_scattering2.swf>. Acesso em: 1 out. 2013.

Conforme se observa na Figura 13, a simulação possui uma semelhança estrutural com o experimento histórico de Geiger-Marsden. Por essa semelhança estrutural e por permitir ainda uma configuração do experimento virtual, esta simulação computacional foi escolhida.

A segunda simulação (KCVS, 2010b) selecionada, que possui o título Up Close Rutherford Scattering, possibilita verificar as trajetórias de partículas alfa em sua interação com o núcleo de um átomo, segundo o modelo atômico de Rutherford. Entre as opções de configuração, é possível selecionar entre diferentes valores de 
energia para as partículas alfa, escolher o núcleo atômico de um entre 4 elementos, e ainda é possível ajustar o parâmetro de impacto para a partícula alfa que será lançada. Uma imagem com a tela capturada da simulação é apresentada na Figura 14, a seguir:

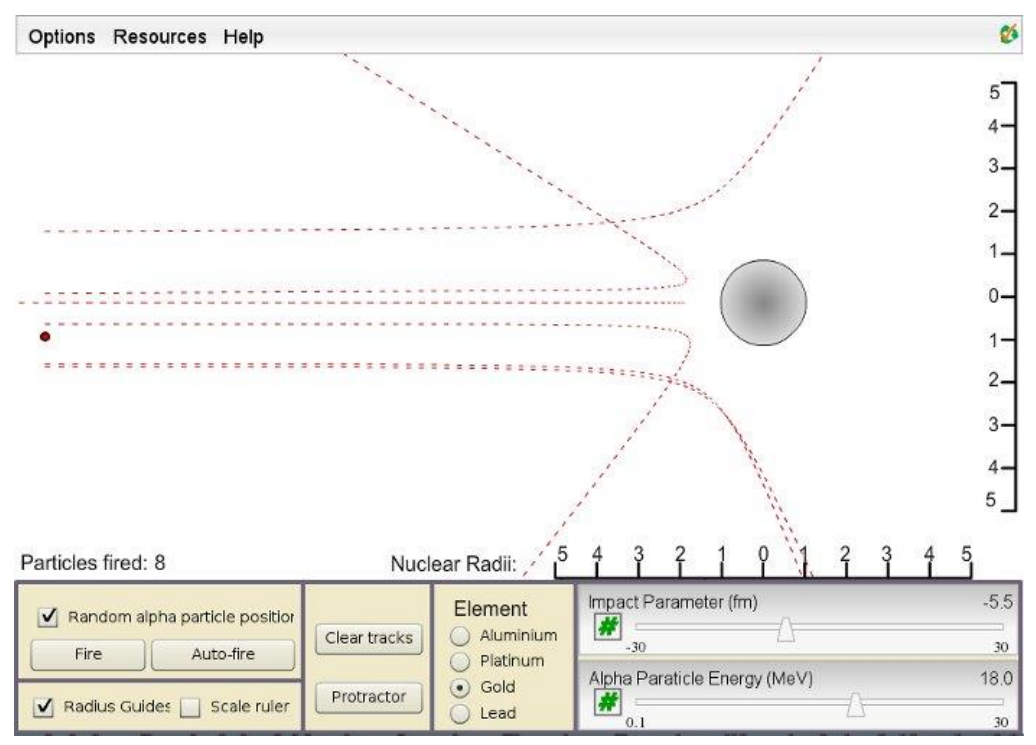

Figura 14. Tela capturada da simulação Up Close Rutherford Scattering que representa o núcleo de um átomo segundo o modelo atômico de Rutherford. Simulação disponível em

<http://www.kcvs.ca/site/projects/physics_files/rutherford/scattering2.swf>. Acesso em: 1 out. 2013.

Esta simulação possui características bem semelhantes a outras que buscam representar o mesmo fenômeno e que, igualmente, estão disponíveis livremente na internet. A simulação foi selecionada por atender aos objetivos didáticos para a realização da atividade, e também por possuir um layout semelhante ao da simulação anterior, o que facilita o seu uso. Outro aspecto que foi considerado na escolha desta simulação foi o fato dela possuir a exibição de gráficos de Força $X$ Distância (ver Figura 15), o que permitiu explorar de forma mais clara a interação elétrica envolvida.

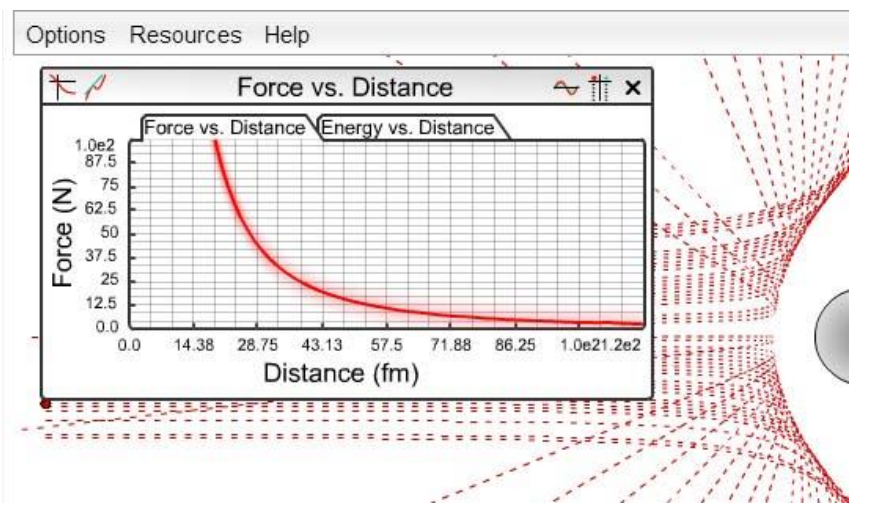

Figura 15. Tela capturada da simulação que representa o núcleo de um átomo segundo o modelo atômico de Rutherford. 
A terceira simulação (KCVS, 2010c) selecionada, que possui o título Scattering and Structure, possibilita a comparação entre as trajetórias envolvidas em interações de diferentes naturezas. Na simulação, além de ser possível verificar as trajetórias de uma partícula alfa lançada contra um núcleo atômico segundo o átomo de Rutherford, é possível verificar as trajetórias em interações mecânicas envolvendo colisões entre uma partícula macroscópica e outros objetos também macroscópicos, com formas circulares, retangulares, etc. Entre as opções de configuração, além de ser possível selecionar o tipo de "núcleo" (um objeto macroscópico ou um núcleo atômico), é possível ajustar o parâmetro de impacto da partícula que será lançada (partícula macroscópica ou partícula alfa). Uma imagem da tela capturada da simulação é apresentada na Figura 16, a seguir:

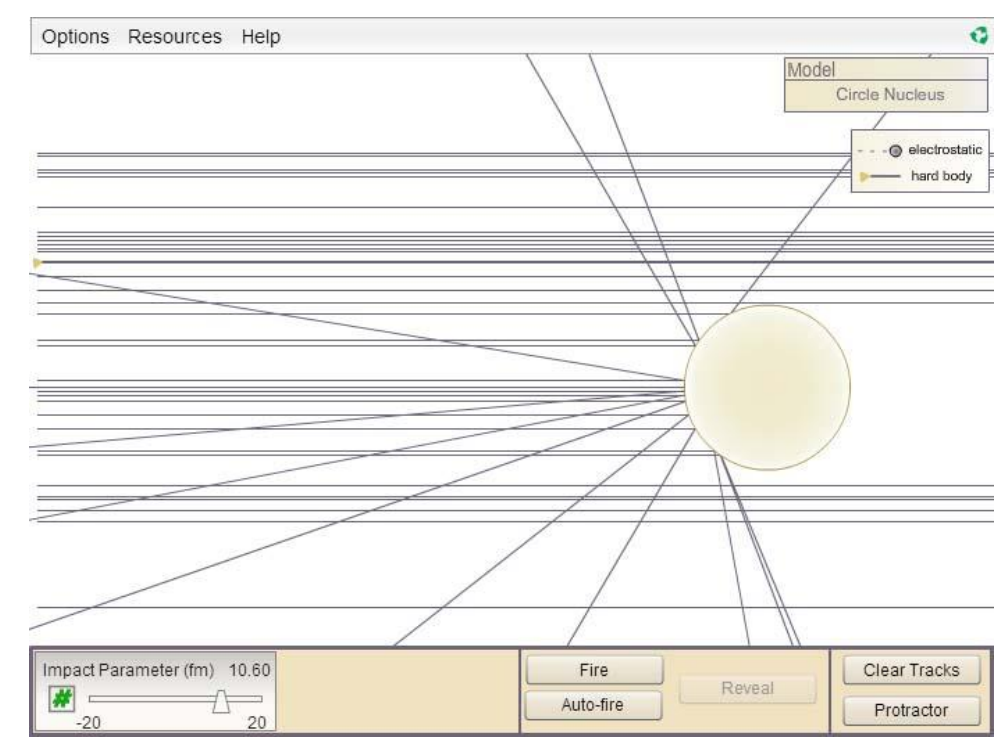

Figura 16. Tela capturada da simulação Scattering and Structure que representa trajetórias para interações de natureza elétrica e mecânica. Simulação disponível em <http://www.kcvs.ca/site/projects/physics_files/rutherford/other_nuclei.swf>. Acesso em: 1 out. 2013.

Esta simulação foi selecionada por possuir um layout semelhante às demais simulações selecionadas, e por atender a uma necessidade de representação das trajetórias envolvidas tanto no experimento histórico de Geiger-Marsden como no experimento real analógico, o que permitiria uma comparação entre tais experimentos.

No roteiro hipertextual disponibilizado aos alunos nos ambientes virtuais foram utilizados também outros recursos computacionais gráficos estáticos, ou seja, imagens digitais, as quais ilustravam determinados aspectos envolvidos nas 
atividades e na discussão dos conceitos. Algumas dessas imagens estão presentes na composição apresentada na Figura 17.

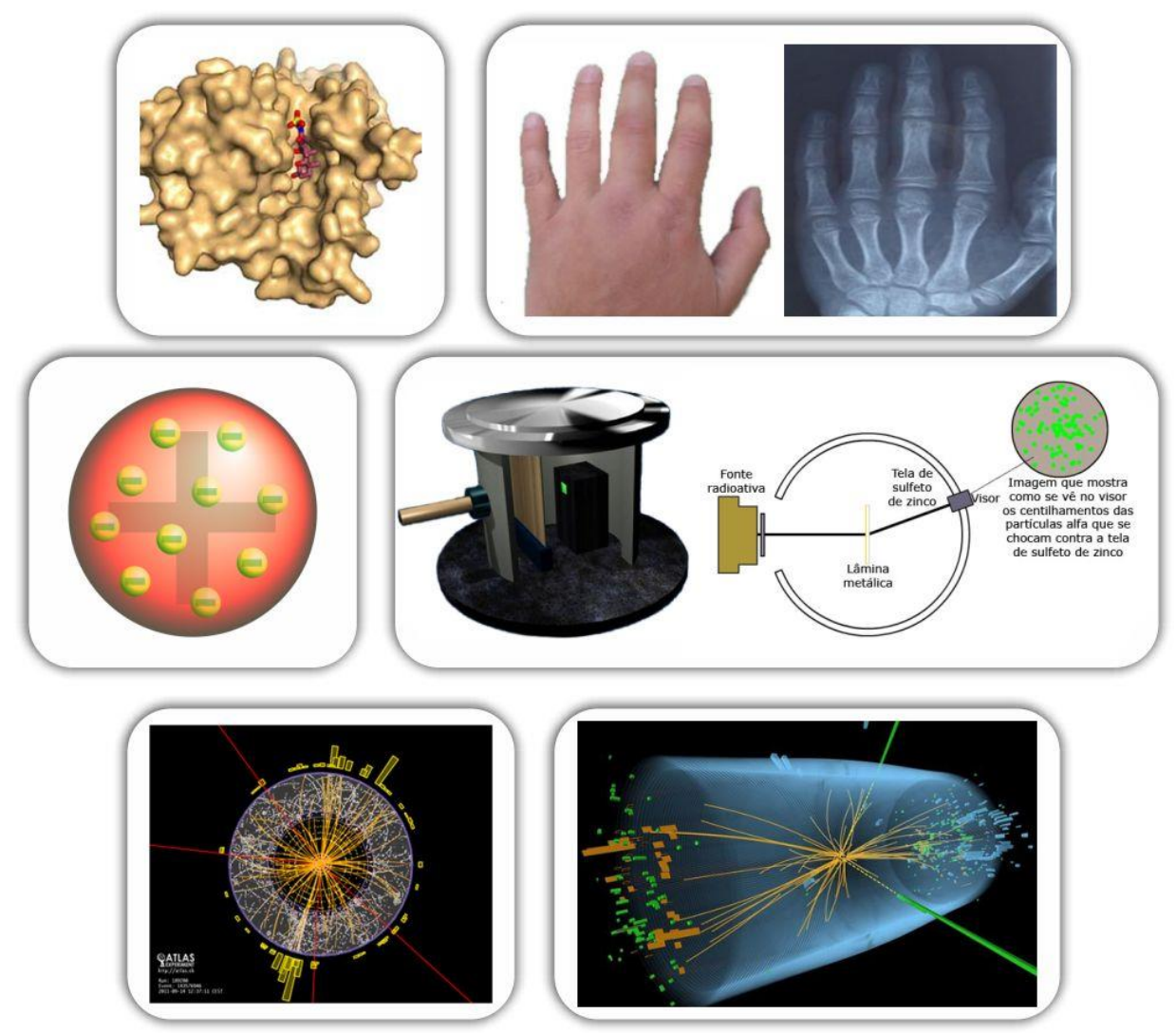

Figura 17. Exemplos de imagens utilizadas no roteiro hipertextual.

Na Figura 17, a imagem à esquerda superior ${ }^{35}$ foi utilizada na atividade de motivação e introdução do curso e representava a estrutura de uma proteína. As imagens localizadas à direita superior ${ }^{36}$ foram utilizadas na discussão sobre o espectro eletromagnético, em que se comparava fotografias e radiografias. A imagem no centro à esquerda ${ }^{37}$ foi uma das representações utilizadas na apresentação do átomo de Thomson. As imagens no centro à direita ${ }^{38}$ foram utilizadas para melhor descrever o experimento histórico de Geiger-Marsden. Já as imagens na parte inferior ${ }^{39}$ se referem a duas representações da detecção no LHC, e foram utilizadas nos contextos catalão e paulista.

\footnotetext{
${ }^{35}$ Imagem obtida no artigo $X$-rays help advance the battle against heart disease, disponível em: <http://www.lightsources.org/cms/?pid=1004615>. Acesso em: 16 nov. 2011.

${ }^{36}$ Imagens do acervo pessoal de membros do CRECIM, disponibilizadas para o uso no curso.

${ }^{37}$ Imagem disponível em: <http://commons.wikimedia.org/wiki/File:Plum_pudding_atom.svg>. Acesso em: 17 nov. 2011.

${ }_{38}$ Imagens elaboradas a partir das simulações Rutherford Scattering Experiment e Rutherford Scattering disponíveis em: <http://www.kcvs.ca/site/projects/physics.html>. Acesso em: 10 nov. 2011.

${ }_{39}$ Imagens obtidas no site de divulgação do experimento ATLAS realizado no LHC, disponíveis em: <http://www.atlas.ch/photos/events.html>. Acesso em 10 jan. 2012.
} 
Além das imagens que faziam parte do roteiro hipertextual, também foram utilizadas outras imagens e animações nos momentos de implementação do curso, as quais se encontravam inseridas nos slides utilizados pelos professores em suas exposições. Como exemplo, na Figura 18 é apresentada uma imagem estática que era utilizada ao comentar os diferentes experimentos que são executados no LHC, imagem esta que foi obtida em um site ${ }^{40}$ de divulgação do European Organization for Nuclear Research (CERN). Já na Figura 19 é apresentada uma tela capturada de uma animação que representava o acelerador de partículas LHC em funcionamento. A animação da qual a imagem foi obtida, foi elaborada no âmbito de um projeto de divulgação científica mantido por pesquisadores da Stockholm University (Suécia) ${ }^{41}$.

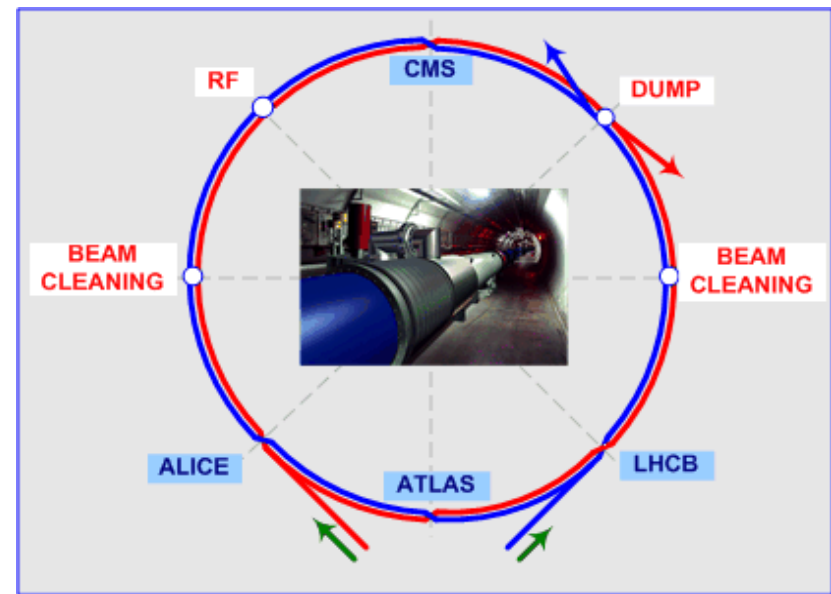

Figura 18. Imagem utilizada ao apresentar os experimentos executados no LHC. Imagem disponível em <http://hc-machine-outreach.web.cern.ch/lhc-machine-outreach/images/lhc-schematic-ml.gif>. Acesso em: 8 nov. 2013.

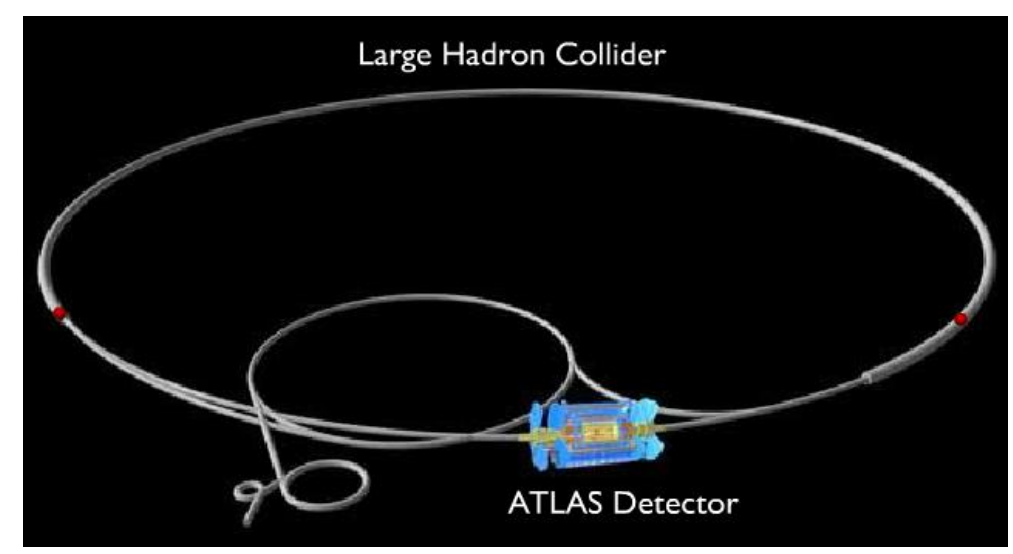

Figura 19. Tela capturada da animação utilizada no curso, que representava o LHC em funcionamento. Animação disponível em <http://hands-oncern.physto.se/ani/acc_lhc_atlas/lhc_atlas.swf>. Acesso em: 8 nov. 2013.

40 Website LHC Machine Outreach, disponível em <http://lhc-machine-outreach.web.cern.ch/>. Acesso em: 8 nov. 2013.

${ }^{41}$ Website Hands-on-CERN Project, disponível em < http://hands-on-cern.physto.se/>. Acesso em: 8 nov. 2013. 


\section{PARTE IV - RESULTADOS, ANÁLISES E CONSIDERAÇÕES}

Os resultados obtidos em nossa pesquisa, acompanhados das devidas análises, são apresentados no capítulo 9. Em seguida, no capítulo 10, último capítulo da presente tese, apresentamos as considerações finais e destacamos algumas possibilidades que podem ser exploradas em trabalhos futuros.

\section{9- RESULTADOS E ANÁLISES}

Em nosso estudo foram identificados variados obstáculos epistemológicos que atuavam em situações de uso de simulações computacionais, alguns deles associados a obstáculos didático-pedagógicos. Os obstáculos epistemológicos, em alguns casos, possuíam uma relação estreita com o uso das simulações e, em outros casos, esta relação era mais distante. No entanto, conforme já comentamos, em consonância com a literatura, entendemos que a questão do sucesso ou insucesso no uso educativo das simulações computacionais vai além das questões técnicas e restritas às simulações; assim, mesmo os obstáculos identificados que possuem uma relação menos direta com as simulações, têm uma relevância no entendimento da aprendizagem com o uso destas simulações.

Os resultados e análises são apresentados neste capítulo organizados segundo uma tipologia de obstáculos epistemológicos e a partir de uma descrição da situação didática em que os obstáculos emergiram e em que eram utilizadas as simulações. Cada situação didática é identificada no texto por um código no formato $\mathbf{S}_{\boldsymbol{m}}\left(\boldsymbol{I}_{\boldsymbol{n}}\right)$, em que $\boldsymbol{m}$ é um número que identifica a situação segundo a ordem em que aparece no texto, e a parte do código $I_{n}$ se refere à implementação em que ocorreu a situação, conforme os mesmos códigos que identificam as implementações, e que são apresentados no Quadro 1 no capítulo 7. Assim, por exemplo, a primeira situação que ocorreu na $3^{a}$ implementação do curso, é identificada com o código $\mathrm{S}_{1}\left(\mathrm{I}_{3}\right)$.

$\mathrm{Na}$ apresentação das situações são expostos os diálogos transcritos, com uma identificação dos participantes também por meio de rótulos e códigos. Os professores, como não tiveram sua participação restrita a uma única implementação, são identificados segundo o código que apresentamos no tópico 7.1.1: $\mathbf{P}_{\boldsymbol{0}}, \mathbf{P}_{\mathbf{1}}, \mathbf{P}_{\mathbf{2}} \mathrm{e}$ 
$\mathbf{P}_{\mathbf{3}}$ são os professores participantes no contexto catalão; $\mathbf{P}_{4}$ e $\mathbf{P}_{5}$ são os professores participantes no contexto paulista. Já os alunos, que participaram cada um de uma única implementação, são identificados por um código $\mathbf{A}_{w}\left(\mathbf{I}_{n}\right)$. A parte do código $I_{n}$ indica a implementação em que o aluno participou, conforme a identificação da implementação que já descrevemos. Já a parte do código $\boldsymbol{A}_{\boldsymbol{w}}$, onde $\boldsymbol{w}$ é um número, identifica o aluno dentro de uma implementação segundo a ordem em que 0 aluno se manifestou naquela implementação. Considerando as situações que foram analisadas, por exemplo, o segundo aluno a se manifestar entre as situações que ocorreram na implementação $\mathbf{I}_{6}$, é identificado como $\mathbf{A}_{2}\left(\mathbf{I}_{6}\right)$.

Em relação ao momento de desenho e aos momentos de redesenhos do curso, quando indicados neste capítulo serão identificados por um código com o formato $\mathbf{D S}_{\boldsymbol{z}}$, segundo o que já foi apresentado no Quadro 1 do Capítulo 7. No código, a letra $\boldsymbol{z}$ é um número que identifica cronologicamente o momento de desenho ou redesenho, sendo o desenho da versão piloto do curso identificado como $\mathbf{D}_{0}$, e o último redesenho, que ocorreu antes da última implementação em São Paulo, identificado como $\mathbf{D}_{5}$.

Por fim, em meio a algumas transcrições são efetuados comentários de forma a tornar mais claro a situação que é apresentada. Os comentários são apresentados em itálico e entre colchetes.

\section{1- Uma tipologia de obstáculos epistemológicos}

Conforme já comentado, os resultados e análises de nossa pesquisa são apresentados organizados segundo uma tipologia de obstáculos epistemológicos. A tipologia utilizada surgiu durante as análises dos dados obtidos, mas foi inspirada na tipologia de obstáculos epistemológicos de Bachelard (1996) que é apresentada ao longo de sua obra $A$ formação do espírito científico.

Em sua obra, ao fazer uma análise histórica da evolução da ciência, Bachelard (1996) reconhece o obstáculo da experiência primeira como mais relacionado à percepção direta e ingênua dos fenômenos e objetos que povoam o cotidiano que, de certa forma, está relacionada com os conhecimentos que permeiam o senso comum e que, assim, foram englobados em nossa análise em uma categoria dita obstáculos da percepção direta. Bachelard também apresenta vários tipos de obstáculos que estão associados ao uso inadequado ou inesperado 
de metáforas, analogias e imagens na explicação e construção científica. O obstáculo verbal, o obstáculo substencialista, o obstáculo animista e o mito da digestão se encaixam neste conjunto de obstáculos, que chamamos de obstáculos da metáfora, da analogia e da imagem. Por fim, outros tipos de obstáculos apresentados por Bachelard, o conhecimento geral, o obstáculo realista, o conhecimento unitário e pragmático e o conhecimento quantitativo, envolvem uma restrição, precipitação ou extrapolação no raciocínio. A este conjunto de obstáculos chamamos de obstáculos do raciocínio limitado ou incongruente.

Alguns dos obstáculos epistemológicos identificados em nosso estudo não se enquadram na tipologia de Bachelard, no entanto, podem ser incluídos em um dos três grupos mais gerais citados acima, que a nosso ver e conforme destacamos, abrangem a tipologia de Bachelard. Assim, classificamos os obstáculos epistemológicos identificados em nosso estudo com base nos três grupos de obstáculos. De forma a tornar mais claro a definição e limites de cada grupo de obstáculo, o Quadro 4, a seguir, apresenta a definição da tipologia utilizada na nossa categorização que se baseia nos três grupos,:

\begin{tabular}{|c|c|}
\hline $\begin{array}{l}\text { Grupos de } \\
\text { obstáculos }\end{array}$ & Definição \\
\hline $\begin{array}{l}\text { Obstáculos da } \\
\text { percepção direta }\end{array}$ & $\begin{array}{l}\text { Nesta categoria estão envolvidos obstáculos que } \\
\text { resultam da percepção da experiência cotidiana. São } \\
\text { formas de conhecer que se apoiam no facilmente } \\
\text { perceptível, sem um processo analítico (empírico e } \\
\text { racionalmente orientado). Incluem-se nesta categoria as } \\
\text { formas de conhecer próprias do senso comum que } \\
\text { permeiam muitas das concepções espontâneas dos alunos. }\end{array}$ \\
\hline $\begin{array}{c}\text { Obstáculos da } \\
\text { metáfora, da analogia } \\
\text { e da imagem }\end{array}$ & $\begin{array}{l}\text { Nesta categoria estão evolvidos obstáculos que surgem } \\
\text { a partir de um uso inadequado ou inesperado das } \\
\text { analogias, metáforas e de imagens na explicação e } \\
\text { construção do conhecimento científico. Resultam de uma } \\
\text { valorização inadequada de características do análogo, da } \\
\text { figura metafórica ou de imagens conhecidas, os quais são } \\
\text { utilizados para ilustrar ou explicar determinados aspectos } \\
\text { de um objeto de estudo, mas não o objeto em sua } \\
\text { integridade. }\end{array}$ \\
\hline $\begin{array}{l}\text { Obstáculos do } \\
\text { raciocínio limitado ou } \\
\text { incongruente }\end{array}$ & $\begin{array}{l}\text { São formas de pensar limitadas ou ilógicas, que geram } \\
\text { explicações insatisfatórias. Em alguns casos, o pensamento } \\
\text { fica limitado a uma interpretação superficial e descritiva do } \\
\text { observável, mas que leva a regras gerais. Em outros casos, } \\
\text { o pensamento tende a extrapolar conclusões de uma } \\
\text { situação limitada para outras situações, sem uma devida } \\
\text { análise e/ou teste. }\end{array}$ \\
\hline
\end{tabular}

Quadro 4. Tipologia de obstáculos epistemológicos. 


\section{2- Obstáculos epistemológicos identificados}

Segundo a tipologia acima descrita, apresentamos a seguir as situações em que obstáculos epistemológicos foram identificados e efetuamos uma análise sobre cada uma das situações. Uma lista das situações, com a identificação do tipo de obstáculo epistemológico atuante, é apresentada no Quadro 5:

\begin{tabular}{|c|c|c|}
\hline $\begin{array}{l}\text { Grupo de } \\
\text { Obstáculo }\end{array}$ & Subgrupo de obstáculo & Situação \\
\hline \multirow{12}{*}{$\begin{array}{l}\text { Obstáculos da } \\
\text { percepção direta }\end{array}$} & \multirow{4}{*}{ Representação vetorial da Força elétrica } & $\mathrm{S}_{1}\left(\mathrm{I}_{3}\right)$ \\
\hline & & $\mathrm{S}_{2}\left(\mathrm{I}_{3}\right)$ \\
\hline & & $\mathrm{S}_{3}\left(\mathrm{I}_{5}\right)$ \\
\hline & & $\mathrm{S}_{4}\left(\mathrm{I}_{6}\right)$ \\
\hline & \multirow{8}{*}{$\begin{array}{l}\text { Colisão no mundo micro e a percepção de colisões } \\
\text { no mundo macro }\end{array}$} & $\mathrm{S}_{5}\left(\mathrm{I}_{1}\right)$ \\
\hline & & $\mathrm{S}_{6}\left(\mathrm{I}_{1}\right)$ \\
\hline & & $\mathrm{S}_{7}\left(\mathrm{I}_{3}\right)$ \\
\hline & & $\mathrm{S}_{8}\left(\mathrm{I}_{3}\right)$ \\
\hline & & $\mathrm{S}_{9}\left(\mathrm{I}_{4}\right)$ \\
\hline & & $\mathrm{S}_{10}\left(\mathrm{I}_{5}\right)$ \\
\hline & & $\mathrm{S}_{11}\left(\mathrm{I}_{5}\right)$ \\
\hline & & $\mathrm{S}_{12}\left(\mathrm{I}_{5}\right)$ \\
\hline \multirow{2}{*}{$\begin{array}{l}\text { Obstáculos da } \\
\text { metáfora, } \\
\text { analogia e da } \\
\text { imagem }\end{array}$} & $\begin{array}{l}\text { Atribuição de propriedades ao objeto da metáfora: } \\
\text { obstáculo verbal }\end{array}$ & $\mathrm{S}_{13}\left(\mathrm{I}_{2}\right)$ \\
\hline & Leitura guiada pela imagem conhecida & $\mathrm{S}_{14}\left(\mathrm{I}_{2}\right)$ \\
\hline \multirow{4}{*}{$\begin{array}{l}\text { Obstáculos do } \\
\text { raciocínio } \\
\text { limitado ou } \\
\text { incongruente }\end{array}$} & $\begin{array}{c}\text { Raciocínio limitado que leva a regras gerais e } \\
\text { superficiais }\end{array}$ & $\mathrm{S}_{15}\left(\mathrm{I}_{3}\right)$ \\
\hline & \multirow{3}{*}{ Extrapolando o limite das conclusões } & $\mathrm{S}_{16}\left(\mathrm{I}_{2}\right)$ \\
\hline & & $\mathrm{S}_{17}\left(\mathrm{I}_{4}\right)$ \\
\hline & & $\mathrm{S}_{18}\left(\mathrm{I}_{5}\right)$ \\
\hline
\end{tabular}

Quadro 5. Lista de situações com a identificação do tipo de obstáculo epistemológico atuante.

\subsection{1- Obstáculos da percepção direta}

Identificamos em nosso estudo diversos obstáculos relacionados à categoria de obstáculos epistemológicos da percepção direta, os quais ocorreram com certa frequência na maioria das implementações. Tais obstáculos foram divididos em dois subgrupos, um relacionado à representação vetorial da força elétrica, e outro relacionado à ideia de colisão mecânica.

\section{- Representação vetorial da força elétrica}

Durante as discussões que ocorriam na atividade III- Estrutura do Átomo, no tópico 6 que abordava o modelo atômico nuclear de Rutherford, os alunos utilizavam 
a simulação Up Close Rutherford Scattering (Figura 14) que permitia verificar o comportamento da partícula alfa ao se movimentar em direção a um núcleo atômico. $\mathrm{Na}$ atividade, uma das questões colocadas (questão 6F, no Apêndice B), solicitava aos alunos que configurassem as opções na simulação com determinados parâmetros e a executassem para gerar uma imagem semelhante à apresentada na Figura 20, a seguir. Em seguida, se solicitava aos alunos que, no dossiê, desenhassem o vetor força elétrica atuante sobre a partícula alfa em três posições de sua trajetória, uma próxima ao início da trajetória (mais à esquerda), uma próxima ao núcleo e outra após o desvio (ao final da trajetória).

Figura 20. Representação da trajetória da partícula alfa em seu deslocamento próximo ao núcleo atômico.

As transcrições dos diálogos ${ }^{42}$ de algumas das situações de emersão do obstáculo, acompanhados de alguns comentários, são apresentadas a seguir:

\section{Situação $S_{1}\left(\underline{1}_{3}\right)$}

Nessa situação, o professor $\mathbf{P}_{\mathbf{3}}$ questiona um grupo de alunos sobre os desenhos por eles efetuados:

$\mathbf{P}_{3}$ : Para esta partícula, como atua a força? Aqui [aponta para o desenho de uma aluna], já desenhou um vetor. O vetor vai para lá? [aponta para a direita do desenho, para o lado onde estava o núcleo atômico]

$A_{10}\left(I_{3}\right): \operatorname{Sim}$

$A_{11}\left(I_{3}\right)$ : Não, porque repele.

$\mathbf{P}_{3}$ : Repele ou se atrai?

$A_{10}\left(I_{3}\right):$ Se repele.

$\mathbf{P}_{3}$ : Portanto, não pode ser que tenha o mesmo sentido do movimento.

\footnotetext{
${ }^{42}$ Vale lembrar que os professores $\mathrm{P}_{0}, \mathrm{P}_{1}, \mathrm{P}_{2}$ e $\mathrm{P}_{3}$ eram catalães e consequentemente as situações em que aparecem foram traduzidas do catalão para o português. Isto pode gerar transcrições truncadas ou sem estilo, pois as traduções foram feitas pelo próprio autor, ainda que com o apoio de membros do CRECIM/UAB.
} 
$\mathrm{A}_{11}\left(\mathrm{I}_{3}\right)$ : É ao contrário, não?

$\mathbf{P}_{3}$ : Uma coisa: o que acontece com a partícula, fica mais lenta ou mais rápida quando se aproxima do núcleo?

$A_{11}\left(I_{3}\right)$ : Mais lenta.

$\mathbf{P}_{3}$ : Mais lenta. Portanto, para onde estará a força? Para onde será a aceleração?

$A_{10}\left(I_{3}\right)$ : Negativa.

$A_{11}\left(I_{3}\right)$ : Ao contrário.

$\mathbf{P}_{3}$ : Ao contrário desta, pois se a velocidade diminui ficando cada vez mais lenta... Então...

Como é possível notar no diálogo acima, o professor $\mathbf{P}_{\mathbf{3}}$ identifica no desenho de uma das alunas do grupo uma representação incorreta do vetor da força elétrica, o qual é desenhado com o mesmo sentido do movimento, o contrário do esperado para uma força de repulsão que faz com que a partícula alfa diminua sua velocidade ao longo de seu movimento.

Algo semelhante ocorre na situação a seguir, em que em meio a uma discussão conjunta com toda a turma, o aluno $\mathbf{A}_{13}\left(\mathbf{I}_{3}\right)$ desenha na lousa digital o que já havia desenhado em seu dossiê:

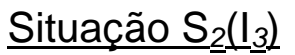

$\mathbf{P}_{1}$ : Imagine que tem três posições. Uma aqui [indica o início da trajetória], uma outra próxima [indica uma posição próxima ao núcleo], e uma após o desvio. Você tem que desenhar, irá representar a interação entre o núcleo e a partícula alfa nestas três posições. Entende o que eu digo?

$A_{13}\left(I_{3}\right)$ : Não.

$\mathbf{P}_{1}$ : Ah. Eu expliquei: tem o apagador sobre a mão, represente as forças sobre o apagador [se refere a uma explicação anterior, em que utilizou 0 apagador e explicou as forças atuantes sobre ele].

$\mathrm{A}_{13}\left(\mathrm{I}_{3}\right):$ Ok.

$\mathrm{P}_{1}:$ Ok?

[O aluno $\boldsymbol{A}_{13}\left(I_{3}\right)$ desenha os vetores. O desenho é apresentado na Figura 21]. 


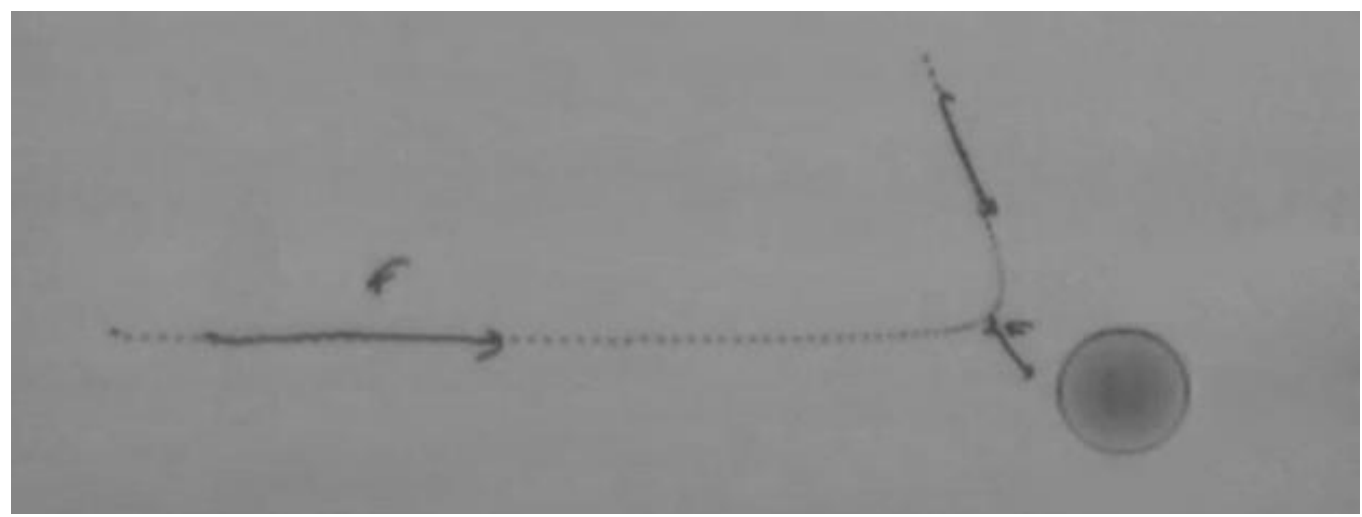

Figura 21. Desenho do aluno $\mathbf{A}_{13}\left(I_{3}\right)$, que indica erroneamente os vetores da força elétrica atuante sobre a partícula alfa em seu deslocamento próximo ao núcleo atômico.

Conforme se pode observar no desenho, os três vetores desenhados estão incorretos. O vetor à esquerda possui um sentido oposto ao esperado, não representando uma força de repulsão. O vetor também possui um comprimento grande comparado aos demais, representando uma maior intensidade da força elétrica na posição, o contrário do esperado. Para o ponto mais à esquerda, a intensidade da força deveria ser menor que as demais atuantes nos outros pontos, afinal, a partícula alfa e o núcleo estão a uma distância maior. Já o vetor desenhado para uma posição da partícula alfa em um ponto próximo ao núcleo possui uma indicação parcialmente correta do sentido, pois aponta para a esquerda superior, no entanto, está fora da linha de ação que passaria pela partícula alfa e pelo centro do núcleo atômico. Além disso, a força também é representada erroneamente como possuindo uma pequena intensidade, com um vetor de pequeno comprimento, o que não representa a força elétrica que estaria atuando neste caso em que a distância é pequena. Já o último vetor, que representa a força elétrica atuante sobre a partícula para uma posição mais ao final da trajetória, se apresenta mais adequado, com um comprimento mediano (comparado aos demais), o que corresponderia corretamente à intensidade da força elétrica, e também possui um sentido apontando para a esquerda superior, ainda que um pouco fora da linha de ação da força.

Após o aluno $\mathbf{A}_{13}\left(\mathbf{I}_{3}\right)$ desenhar, $\mathbf{P}_{1}$ discute o desenho com a turma:

$\mathbf{P}_{1}$ : Ok. Vejamos. Vamos comentar. Este eu não faria igual [indica o vetor mais à esquerda na imagem da Figura 21]. Tem aqui a partícula alfa. Sim? Com uma carga positiva. E aqui o núcleo positivo. E a flecha está para lá [indica o vetor à esquerda, com o seu sentido para o núcleo]. Temos duas cargas positivas.

Muitos alunos: Se repelem. 
$\mathbf{P}_{1}$ : Se repelem. Se repelem. Portanto, a flecha pode estar para a direita?

Muitos alunos: Não.

$\mathbf{P}_{1}$ : Não seria mais lógico colocar para outro sentido? Entendem? Está repelindo. O núcleo repele a carga positiva.

[Trecho não compreensível]

$\mathbf{P}_{1}$ : Vejamos. Estendam os braços um pouco assim [fala para um grupo de alunos]. Melhor, levante você. Você. Venha para cá e nós faremos um freio. Ok? Vai [aluno se movimenta com outros alunos e a professora o freando]. O que lhe está acontecendo? Está freando. Estou fazendo uma força que o está repelindo quando ele vem para cá. Sim? Ele é a partícula alfa, vai para lá, e o que encontra? Algo que o está freando. Ok? Mas ele continua avançando. Mas ele diminui o quê?

$A_{14}\left(I_{3}\right):$ A velocidade.

$\mathbf{P}_{1}$ : A velocidade. Portanto, por haver uma força para lá [aponta da direita para a esquerda], impede-se que continue avançando?

Muitos alunos: Não.

$\mathbf{P}_{1}$ : Não? Quando vai em um carro e quer diminuir a velocidade, freia um pouco e continua avançando. De acordo? Sim? Ok. Agora vejamos essa outra... Portanto, como poderia colocá-la? Para a esquerda, ok? Estão de acordo? Sim? Vou a colocar, por exemplo, para cá [aponta para uma posição próxima ao núcleo na trajetória]. De acordo? Sim? Vejamos, e como a distância é muito grande [aponta para a fórmula da força elétrica desenhada no quadro negro], a força está dividindo, a força será pequena, a força será pequena. Agora, em uma posição próxima. Ouviram o que acabei de dizer? Se está muito próxima, como será a força? Grande ou pequena?

Muitos alunos: Grande.

$\mathbf{P}_{1}$ : Muito grande. Ok? Ok. E para onde atuarão? Estão de acordo com estes desenhos?

Muitos alunos: Não.

$\mathbf{P}_{1}$ : Como seria?

$A_{15}\left(I_{3}\right):$ A repele.

$\mathbf{P}_{1}$ : Estão dizendo que repele [aponta para a partícula no ponto mais próximo do núcleo]. Portanto, no ponto de ação, na linha de ação, aonde seria? Para lá [aponta em uma diagonal superior, da direita para esquerda, e desenha o vetor]. Vejamos, poderia ser como a Lua que está dando voltas. A Terra o que faz com a Lua? A está repelindo ou a está atraindo? A atrai, pois está girando, mudando de direção. Percebem? É como se fosse a Lua aqui [indica a partícula alfa desenhada sobre a trajetória], por exemplo, e a Terra aqui [indica o canto superior esquerdo no desenho, oposto à posição do núcleo]. Ok? Ao contrário, pois isto é repulsão. Ok. Agora, aqui [indica no desenho uma posição ao final da trajetória] como seria? Estão de acordo com esta representação ou mudariam? Primeiro pensem: Repulsão ou atração?

Muitos alunos: Repulsão. 
$\mathbf{P}_{1}$ : Repulsão. Portanto, o núcleo repele, a flecha será para lá [aponta no sentido oposto ao núcleo] ou para cá [aponta no sentido do núcleo]? Como está. Sim? Está correto. Agora, será maior que aquela e menor que esta [se refere, respectivamente, ao vetor no ponto mais afastado do núcleo e ao vetor no ponto mais próximo do núcleo]. Estão de acordo? Seria um intermediário. Ok? Eu faria um pouco maior que esta. Muito bem.

Como se observa, $\mathbf{P}_{\mathbf{1}}$ tenta desconstruir a ideia envolvida no desenho do aluno, em que alguns dos vetores estariam mais associados a um vetor da velocidade que a um vetor da força. Para isso, $\mathbf{P}_{\mathbf{1}}$ procura levar os alunos a perceberem que a força elétrica, sendo de repulsão, seria contrária ao movimento representado na trajetória e provocaria a redução da velocidade no intervalo em que a partícula alfa se aproxima do núcleo. $\mathbf{P}_{\boldsymbol{1}}$ também procura levar os alunos a perceberem, ao se referenciar à fórmula previamente desenhada no quadro negro, que a intensidade da força representada pelo tamanho do vetor deveria estar associada inversamente à distância entre partícula alfa e núcleo atômico.

Por fim, $\mathbf{P}_{\mathbf{1}}$ também utiliza uma analogia para explicar o desvio da partícula alfa em um movimento que lembra uma parábola. $\mathbf{P}_{\mathbf{1}}$ compara o movimento da partícula alfa, sob o efeito de uma força de repulsão, com o movimento da Lua ao redor da Terra, que ocorre sob o efeito de uma força de atração. Ainda que as forças envolvidas possuam naturezas diferentes, e uma seja de repulsão e a outra seja de atração, a analogia parece não ter levado a resultados inesperados, não tendo sido identificada nenhuma referência a ela pelos alunos na sequência da aula.

As duas situações apresentadas, $\underline{S}_{1}\left(\underline{I}_{3}\right)$ e $\underline{S}_{2} \underline{I}_{3} \underline{I}_{2}$ ocorreram no contexto catalão. A seguir, apresentamos duas outras situações em que o mesmo erro na representação dos vetores foi cometido por alunos no contexto paulista.

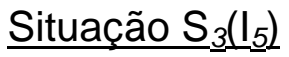

$\mathrm{Na} 1^{\text {a }}$ implementação do curso no contexto paulista $\left(\mathbf{I}_{5}\right)$, registramos 0 diálogo a seguir, em que o professor $\mathbf{P}_{\mathbf{4}}$ observa o desenho de um dos alunos de um grupo e explica a representação vetorial para a força elétrica entre a partícula alfa e o núcleo:

[ $\boldsymbol{P}_{4}$ observa o desenho feito pelo aluno $\left.\boldsymbol{A}_{9}\left(\mathbf{I}_{5}\right)\right]$.

$\mathbf{P}_{4}$ : $\mathrm{O}$ vetor está correto? [pergunta indicando o vetor desenhado no início da trajetória] Você tem a partícula alfa e o núcleo. Você continua tendo carga positiva e carga positiva.

$\mathbf{A}_{9}\left(\mathbf{I}_{5}\right)$ : Não seria pra cá? [aponta para a direita da partícula alfa] 
$\mathbf{P}_{4}$ : Na verdade seria pra lá [aponta para a esquerda da partícula alfa]. O que a força faz? Ela altera a velocidade. A força continua pra lá, e faz com que diminua a velocidade.

$A_{9}\left(I_{5}\right)$ : Ah! Então é pra lá [aponta para a esquerda da partícula alfa].

$\mathbf{P}_{4}$ : Lembra da Segunda lei de Newton? Força é igual à massa vezes aceleração.

$A_{9}\left(I_{5}\right): \operatorname{Sim}$.

$\mathbf{P}_{4}$ : Aqui você tem uma força e aqui você tem a aceleração [gesticula indicando posicionamento das grandezas na fórmula]. Vai alterar a velocidade. Você pode ir correndo, e tem uma força contrária que vai the freando até o ponto que você vai começar a voltar.

[Trecho não compreensível]

$\mathbf{P}_{4}$ : Quanta maior a intensidade da força, maior é o vetor. Você tem que pensar também no tamanho do vetor. Qual vetor que é maior, esse aqui [indica uma posição longe do núcleo] ou esse aqui [indica uma posição próxima ao núcleo]?

$A_{9}\left(I_{5}\right)$ : Esse aqui.

$\mathbf{P}_{4}$ : Perfeito!

No trecho acima, o aluno $\mathbf{A}_{9}\left(\mathbf{I}_{5}\right)$ havia desenhado um dos vetores, referente a uma posição da partícula alfa no início da trajetória, semelhante ao apresentado anteriormente na Figura 21, com um sentido da esquerda para a direita e representando uma intensidade maior que as forças nas outras duas posições. Nessa situação, após lembrar que partícula alfa e núcleo eram positivos, implicitamente destacando que força seria de repulsão, $\mathbf{P}_{4}$ afirma que o sentido da força seria oposto ao sentido do movimento. A partir da expressão matemática da segunda Lei de Newton, $\mathbf{P}_{4}$ procura explicar também que o efeito da força de repulsão seria verificado na diminuição da velocidade. Como se pode observar, a intervenção do professor acaba sendo mais direta se comparada àquelas efetuadas no contexto catalão, mas parece ter permitido ao aluno $A_{9}\left(I_{5}\right)$ reconhecer o seu erro.

Na sequência, conforme apresentado a seguir, $\mathbf{P}_{4}$ se dedica de forma mais precisa a uma desconstrução da ideia por detrás do erro. A aluna $\mathbf{A}_{10}\left(\mathbf{I}_{5}\right)$, que acompanhava o diálogo entre $\mathbf{A g}_{9}\left(\mathbf{I}_{5}\right)$ e $\mathbf{P}_{4}$, questiona a este último se a representação dos vetores feita por ela estaria correta: 
$\mathbf{A}_{10}\left(\mathbf{I}_{5}\right)$ : É mais ou menos assim? [apresenta seu desenho com os vetores representados de forma semelhante ao apresentado na Figura 21]

[Trecho não compreensível]

$A_{10}\left(I_{5}\right)$ : A força vai aumentando, vai chegando. $E$ depois, vai diminuindo, diminuindo, diminuindo. [comenta ao mesmo momento em que aponta para o desenho seguindo a trajetória]

$\mathbf{P}_{4}$ : Na verdade a força, a força vai aumentando conforme vai se aproximando. Ok? Essa força é de atração ou de repulsão? É de repulsão.

$A_{10}\left(I_{5}\right)$ : Então. Ele vai, como você falou, ele vai correndo, correndo, correndo. Vai vindo a força e você vai diminuindo a velocidade. Aqui, a mesma coisa, ele vai chegando perto, vai diminuindo. Os dois se repelem e ela desvia.

$\mathbf{P}_{4}$ : Olha só. A força, quanto mais próximo, maior. É força de repulsão.

$A_{10}\left(I_{5}\right): \operatorname{Sim}$.

$\mathbf{P}_{4}$ : É de repulsão. Então essa força aqui vai tá pra cá [indica o lado oposto ao núcleo] ou pra cá [indica o lado onde está o núcleo]? A seta vai tá pra cá [indica o lado oposto ao núcleo] ou pra cá [indica o sentido contrário ao núcleo]?

$A_{10}\left(I_{5}\right):$ Vai...

$\mathbf{P}_{4}$ : Se tá repelindo...

$\mathrm{A}_{10} \mathrm{l}_{4}$ : Ah! Pra cá [indica o sentido contrário ao núcleo].

$\mathbf{P}_{4}$ : Pra cá [indica o sentido contrário ao núcleo]. E quando a seta vai ser maior?

$A_{10}\left(I_{5}\right)$ : Aqui, porque a força aqui vai ser maior.

$\mathbf{P}_{4}$ : Isso.

$A_{10}\left(I_{5}\right): A h$, tá!

$\mathbf{A}_{9}\left(\mathbf{I}_{5}\right)$ : Então essas setas [se refere às forças atuando nas demais posições] vão estar pra cá [indica o lado esquerdo superior do desenho]. Essa aqui vai ser maior [indica a posição mais próxima ao núcleo]. Depois do desvio vai ser assim [desenha um vetor para uma posição ao final da trajetória].

$\left[\boldsymbol{P}_{4}\right.$ gesticula confirmando].

Nos trechos apresentados é possível perceber que $\mathbf{P}_{4}$, ao notar que $\mathbf{A}_{9}\left(\mathbf{I}_{5}\right)$ e $\mathbf{A}_{10}\left(\mathbf{I}_{5}\right)$ traçaram os vetores associando-os ao sentido da trajetória e com uma intensidade (tamanho dos vetores) semelhante ao esperado para a velocidade, procura levar os alunos a perceberem o erro. Nos dois trechos, tanto para o aluno $\mathbf{A}_{9}\left(\mathbf{I}_{5}\right)$ como para a aluna $\mathbf{A}_{10}\left(\mathbf{I}_{5}\right)$, a constatação do erro por parte dos alunos parece ter ocorrido. No segundo trecho, em que $\mathbf{P}_{4}$ se dedica a desconstruir a ideia que 
sustenta o erro, é possível perceber uma argumentação semelhante àquela empregada por $\mathbf{P}_{\mathbf{1}}$ nas situações ocorridas no contexto catalão.

Na última implementação do curso $\left(\mathbf{I}_{6}\right)$, na situação transcrita a seguir, $\mathbf{P}_{\mathbf{4}}$ também apresenta uma abordagem em que tenta desconstruir a ideia por detrás do erro:

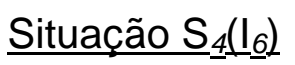

Nesta situação, $\mathbf{P}_{4}$ se aproxima de dois alunos e os questiona sobre 0 desenho dos vetores:

$\mathbf{P}_{4}$ : Vocês fizeram o desenho? Desenharam os vetores?

$\mathbf{A}_{1}\left(\mathbf{I}_{6}\right): \operatorname{Sim}$.

$\mathbf{A}_{2}\left(\mathbf{I}_{6}\right)$ : Ele sim, eu não. Não sei como fazer.

$\mathbf{P}_{4}$ : Deixa eu ver $\left[\boldsymbol{A}_{1}\left(\mathbf{I}_{6}\right)\right.$ apresenta o desenho a $\left.\boldsymbol{P}_{4}\right]$. Nesse ponto, o vetor tá apontando pra cá? [indica o sentido para a direita, para o núcleo atômico] Por quê?

$\mathbf{A}_{1}\left(\mathbf{I}_{6}\right)$ : Hum... Não sei. Não é pra cá? [indica uma posição próxima ao núcleo] A partícula vem pra cá. [indica uma posição próxima ao núcleo]

$\mathbf{P}_{4}$ : Vai pra onde?

$A_{1}\left(I_{6}\right)$ : Pra cá. Pro lado do átomo, do núcleo.

[Trecho não compreensível]

$A_{1}\left(I_{6}\right):$ Não tá certo?

$\mathbf{P}_{4}$ : O núcleo atrai ou repele a partícula alfa?

$\mathbf{A}_{1}\left(\mathbf{I}_{6}\right)$ : Repele.

$\mathbf{A}_{2}\left(\mathbf{I}_{6}\right):$ Tem que ser pra cá? [indica o sentido oposto ao núcleo]

$A_{1}\left(I_{6}\right)$ : Mas a partícula tá andando pra cá. [indica uma posição próxima ao núcleo]

$\mathbf{P}_{4}$ : Se é repulsão, é uma força que tá pra cá, afastando.

$\mathbf{A}_{1}\left(\mathbf{I}_{6}\right)$ : Ah, Ok! Acho que entendi. O vetor vai ser pra cá [indica o sentido oposto ao núcleo], é repulsão, é uma força contrária.

$\mathbf{P}_{4}$ : Sim. E o tamanho do vetor?

$A_{1}\left(I_{6}\right):$ Tá errado?

$\mathbf{P}_{4}$ : Olhe lá a fórmula. [aponta a fórmula previamente escrita no quadro negro] Quando a força elétrica é maior? Quando a partícula alfa tá mais perto ou mais longe do núcleo? 
$A_{1}\left(I_{6}\right)$ : Mais perto?

$\mathbf{A}_{1}\left(\mathbf{I}_{6}\right)$ : Então aqui [indica uma posição próxima ao núcleo] a seta tem que apontar pra cá [indica uma posição à esquerda superior do núcleo] e ser grande?

$\mathbf{P}_{4}$ : Sim. E aqui? [indica uma posição após o desvio, ao final da trajetória]

$\mathbf{A}_{1}\left(\mathbf{I}_{6}\right)$ : Aponta pra cá? [indica um sentido para a esquerda superior do núcleo] $\mathrm{E}$ a flecha, o vetor tem que ser menor que esse aqui. [indica uma posição próxima ao núcleo] Mas é maior que o primeiro. [indica uma posição no início da trajetória]

$\mathbf{P}_{4}: \operatorname{Sim}$.

Conforme se observa na situação acima transcrita, o aluno $\mathbf{A}_{1}\left(\mathbf{I}_{6}\right)$ argumenta, em mais de um instante, que a partícula se deslocava no sentido do núcleo e que, portanto, o sentido do vetor deveria ser também para a direita do desenho, onde estava o núcleo. Fica evidente nesta situação a percepção do aluno de que o sentido da força deveria ser o mesmo do movimento.

As situações expostas envolvendo a representação vetorial da força elétrica permitem entender a origem do erro conceitual envolvido, ou seja, sua relação com um obstáculo epistemológico e o papel coadjuvante da simulação Up Close Rutherford Scattering (Figura 14).

O erro na representação vetorial da força, em que se associa o sentido da força ao sentido do movimento e a intensidade da força à intensidade da velocidade do movimento, é algo já conhecido na literatura em ensino de Física nos estudos sobre as concepções prévias e concepções espontâneas dos alunos. Mais que uma concepção cientificamente incorreta, tal noção concepção é fruto de um obstáculo epistemológico e resulta da percepção ingênua e direta dos movimentos no cotidiano. Da experiência cotidiana, entende-se que para um movimento de um corpo se manter deve haver uma força atuando sobre o corpo. Além disso, a ideia de que quanto mais rápido o corpo se move, maior é a força atuante, faz sentido no mundo cotidiano (basta lembrar que um motorista acelera para aumentar a velocidade do carro). Assim, o conceito físico de força é utilizado em geral associado ao conceito físico de velocidade, inclusive quando se utiliza a representação vetorial.

Esta forma de pensamento é resistente, pois se apoia naquilo que pode ser notado diretamente e facilmente na experiência cotidiana. Além disso, como são 
ideias "confirmadas" pelo senso comum, se constituem em obstáculo a toda e qualquer outra forma de pensar que rompa com essa associação entre força e velocidade. No caso destes alunos, a relação se manifestou no uso das simulações, mesmo após estudos anteriores de mecânica e eletricidade, em que houve o tratamento dessa noção de força.

Para que houvesse uma desconstrução das ideias que sustentavam o obstáculo epistemológico, foi necessária uma argumentação que colocasse em evidência a ideia de repulsão elétrica e sua relação com o sentido da força (argumentos de natureza eletrostática). Além disso, na ação dos professores é destacada a relação entre a distância e a intensidade da força elétrica a partir da expressão algébrica da mesma. Vale destacar, que sendo por definição resistente, a superação de um obstáculo epistemológico pode ter sido local. Isto, pois um obstáculo é uma forma de pensamento que pode se aplicar a diversos contextos. Ou seja, a superação verificada pode ser válida apenas na situação investigada, e não necessariamente definitiva para os alunos.

Conforme já comentamos anteriormente, a simulação computacional Up Close Rutherford Scattering assume um papel mais discreto na questão específica tratada. A simulação foi utilizada de forma mais ilustrativa, para gerar uma imagem que já era apresentada no dossiê (material escrito) e no roteiro acessível pelos ambientes virtuais. No entanto, vale destacar que a simulação vinha sendo utilizada ocupando um papel central na maioria das demais questões que tratavam do átomo nuclear. Em outra questão (6E, disponível no Apêndice B), por exemplo, a simulação era utilizada justamente para analisar graficamente (conforme pode ser observado na Figura 15) a relação entre a distância entre duas cargas e a força atuante entre elas.

Vale destacar que, uma vez que aparentemente o obstáculo epistemológico foi superado nas situações apresentadas, resultados de aprendizagem que fossem verificados por uma avaliação aplicada em um momento posterior ao curso, sendo positivos, poderiam levar a uma conclusão pouco precisa de que a simulação foi suficiente para proporcionar aprendizagens. No entanto, como pudemos perceber, a questão da aprendizagem esteve mais associada ao "entorno" da simulação, do que diretamente a ela. 
A seguir, apresentamos outro obstáculo epistemológico, que também podem ser entendidos como obstáculos da percepção direta:

\section{- Colisão no mundo micro e a percepção de colisões no mundo macro}

Outro obstáculo epistemológico identificado em diferentes situações estava relacionado à percepção que os alunos já possuíam sobre colisões e desvios. Neste obstáculo, a percepção dos alunos em sua experiência cotidiana das colisões mecânicas entre objetos macroscópicos, influenciava a interpretação de desvios de corpos carregados e a predição de determinadas interações. As situações em que identificamos a atuação deste tipo de obstáculo são apresentadas a seguir:

\section{Situação $S_{5}\left(\underline{I}_{1}\right)$}

Na primeira implementação do curso $\left(\mathbf{I}_{\mathbf{1}}\right)$, uma questão presente no dossiê e no roteiro acessível pelo ambiente virtual solicitava aos alunos que fizessem um desenho do que deveria ocorrer se uma partícula alfa fosse lançada contra um átomo segundo o modelo de Thomson. A predição que se esperava que fosse feita com essa questão seria posteriormente testada com 0 uso da simulação computacional do experimento de Geiger-Marsden (Rutherford Scattering). enunciado da questão, já traduzido para a língua portuguesa, é apresentado a seguir:

Suponha que disparas partículas alfa contra um determinado átomo de ouro. Faça um esquema de como você imagina que seriam as trajetórias que as partículas alfa seguiriam neste experimento, considerando o átomo de Thomson. Explique em que se baseia para fazer a tua predição.

Junto ao enunciado, havia ainda uma imagem (Figura 22), a qual já possuía uma representação do átomo de Thomson (círculo maior) e a representação de quatro partículas alfa (círculos menores). Sobre a imagem, os alunos deveriam traçar as trajetórias das quatro partículas alfa.

Figura 22. Imagem presente nas questões que envolviam uma predição da interação entre partículas alfa e o átomo de Thomson, utilizada nas implementações $\mathbf{I}_{0}$ e $\mathbf{I}_{1}$. 
$\mathrm{Na}$ situação a seguir, $\mathbf{P}_{\mathbf{1}}$ dialoga com o aluno $\mathbf{A}_{1}\left(\mathbf{I}_{\mathbf{1}}\right)$ sobre o desenho das trajetórias:

$\mathbf{P}_{1}$ : Como você desenhou? A partícula alfa não atravessa o átomo? Por quê?

$\mathbf{A}_{1}\left(\mathbf{I}_{1}\right)$ : Rebate.

$\mathbf{P}_{1}:$ Por que rebate?

$A_{1}\left(I_{1}\right)$ : Porque é de ouro.

$\mathbf{P}_{1}$ : A partícula alfa não pode atravessar um átomo de ouro?

$A_{1}\left(I_{1}\right)$ : O ouro é um metal, não?

$\mathbf{P}_{1}$ : E a partícula alfa não pode atravessar metais?

$\mathbf{A}_{1}\left(\mathrm{I}_{1}\right)$ : É. É que são... são sólidos.

$\mathbf{P}_{1}$ : Vejamos. Quando alguém tira uma radiografia, os Raios $X$ não atravessam algumas partes mais sólidas do corpo?

$A_{1}\left(I_{1}\right): \operatorname{Sim}$.

$\mathbf{P}_{1}$ : Sim. Raios $X$ são um tipo de radiação. A radiação alfa envolve partículas alfa. Dependendo do comprimento de onda da radiação, ela pode penetrar sólidos. Ok?

$A_{1}\left(I_{1}\right)$ : Ok.

$\mathbf{P}_{1}$ : Então, no seu desenho, a partícula alfa poderia atravessar, não?

$\mathbf{A}_{1}\left(\mathbf{I}_{1}\right)$ : Sim. Mas não é compacto?

$\mathbf{P}_{1}:$ O que é compacto?

$A_{1}\left(I_{1}\right)$ : O átomo.

$\mathbf{P}_{1}$ : O átomo de Thomson é compacto? Não entendi... Explique.

$A_{1}\left(I_{1}\right)$ : $O$ texto diz que é maciço. O átomo de Thomson é maciço. É compacto, não? Não poderia atravessar.

$\mathbf{P}_{1}$ : Maciço? Vejamos... Onde está?

[O aluno $\mathbf{A}_{1}\left(\mathrm{I}_{1}\right)$ aponta para um trecho do roteiro]

$\mathbf{P}_{1}$ : "Thomson propôs um modelo atômico, segundo o qual os elétrons se encontravam distribuídos mais ou menos uniforme em uma esfera maciça de carga positiva". [lê o texto disponível no roteiro acessível pelo ambiente virtual] Ok. Não pense no átomo de Thomson como algo impenetrável por ser maciço, pense somente que tem massa. Ok? É maciço por ter massa. As partículas alfa podem atravessá-lo e não é... não é um sólido impenetrável.

$A_{1}\left(I_{1}\right):$ Ok. 
No diálogo acima é possível notar que o aluno $\mathbf{A}_{1}\left(\mathbf{I}_{1}\right)$, baseando-se em uma percepção de que metais sólidos não são penetrados em interações macroscópicas, entendia que o átomo de Thomson não poderia ser atravessado pelas partículas alfa, e estas colidiriam na "superfície" do átomo, sendo desviado em sua trajetória.

Nota-se também que o aluno se apoia em uma descrição disponível no texto apresentado no roteiro do curso, que descrevia o átomo de Thomson como maciço. Tal termo traz consigo, normalmente, uma ideia de impenetrabilidade, o que pode ter contribuído para o equívoco do aluno. Vale ressaltar que o termo maciço foi utilizado erroneamente no material, sendo mais adequado o uso do termo massivo, o qual, no entanto, talvez também poderia ser compreendido de forma equivocada como associado a uma impenetrabilidade. Esta situação, em conjunto com outras relacionadas à mesma questão, será retomada mais à frente, quando discutirmos os obstáculos didático-pedagógicos associados aos obstáculos epistemológicos.

Era fundamental fazer os alunos perceberem e desconstruírem a ideia de que haveria uma colisão das partículas alfa com o átomo de Thomson e que este não poderia ser atravessado. Tal ideia prejudicaria a compreensão dos resultados "experimentais" obtidos na simulação do experimento de Geiger-Marsden, podendo levar a uma não superação do modelo atômico de Thomson. Uma predição adequada segundo o modelo de Thomson não seria compatível com os resultados "experimentais" da simulação.

Conforme apresentado na situação seguinte, mesmo quando a predição é correta, para explicar o fato de algumas partículas alfa se desviarem com ângulos grandes, alguns alunos acabaram recorrendo à ideia de que haveria uma colisão mecânica com a folha de ouro do experimento.

Situação $\underline{S}_{6}\left(\underline{1}_{1}\right)$

No diálogo transcrito a seguir, que ocorreu também na implementação da versão piloto do curso $\left(\mathbf{I}_{1}\right)$, ao utilizar a simulação Rutherford Scattering, um grupo de alunos verifica que algumas partículas alfa apresentam desvios com ângulos grandes, algo que não poderia ser explicado pelo modelo de Thomson:

\footnotetext{
$A_{5}\left(I_{1}\right)$ : Não Sabemos como explicar o resultado.

$\mathbf{P}_{0}$ : Qual resultado?
} 
$A_{5}\left(I_{1}\right)$ : Do experimento. O modelo de Thomson não explica os ângulos grandes.

$\mathbf{P}_{0}$ : Ok. Muito bem.

$A_{5}\left(I_{1}\right)$ : Não sabemos como explicar os ângulos grandes.

$\mathbf{A}_{6}\left(\mathbf{I}_{1}\right)$ : Eu acho que rebate.

$\mathbf{P}_{0}$ : Rebate em quê?

$A_{6}\left(I_{1}\right)$ : Não placa...

$\mathbf{P}_{0}$ : Na placa?

$\mathbf{A}_{6}\left(\mathbf{I}_{1}\right)$ : Sim, na placa de ouro.

$A_{7}\left(I_{1}\right):$ Na lâmina de ouro.

$\mathbf{A}_{6}\left(\mathbf{I}_{1}\right)$ : É. Na lâmina de ouro.

$\mathbf{P}_{0}$ : Rebate na lâmina...

$\mathbf{A}_{5}\left(\mathbf{I}_{1}\right)$ : Eu acho que não pode rebater.

$\mathbf{P}_{0}$ : Do que é composta a lâmina?

$A_{-}\left(I_{1}\right)$ : De ouro.

$\mathbf{P}_{0}$ : Sim, mas a lâmina de ouro é composta de quê?

$A_{7}\left(I_{1}\right):$ De átomos?

$\mathbf{P}_{0}$ : Ok. E qual modelo de átomo que se tinha na época? O de Thomson. Sim? As partículas alfa rebatiam no átomo de Thomson?

$\mathbf{A}_{7}\left(\mathbf{I}_{1}\right)$ e $\mathbf{A}_{5}\left(\mathbf{I}_{1}\right)$ : Não. Atravessavam.

$\mathbf{P}_{0}$ : Atravessavam.

$\mathbf{A}_{6}\left(\mathrm{I}_{1}\right)$ : Porque o átomo é neutro e a carga positiva e a negativa estão distribuídas.

$\mathbf{P}_{0}$ : Ok. Então o átomo de Thomson permite entender os ângulos pequenos. Ok? Mas não os ângulos grandes. Ok? Isso que vocês não sabem como explicar.

$A_{5}\left(I_{1}\right): \operatorname{Sim}$.

$\mathbf{P}_{0}$ : Vocês têm que propor um outro modelo de átomo. Tentem propor. Pense em algo que permita explicar os ângulos grandes e pequenos.

No diálogo anterior, os alunos $\mathbf{A}_{6}\left(\mathbf{I}_{1}\right)$ e $\mathbf{A}_{7}\left(\mathbf{I}_{1}\right)$, na tentativa de explicar os desvios das partículas alfa com ângulos grandes, assumem que estas estariam colidindo com a placa. A explicação dos alunos talvez revele o mesmo obstáculo em que as colisões mecânicas com objetos macroscópicos servem de referência para 
interpretar a interação microscópica. Como se percebe, $\mathbf{P}_{\boldsymbol{0}}$ se detém em sua explicação, ainda que sem apresentar muitos detalhes, a afirmar que a colisão com a folha de ouro não seria possível considerando um átomo de Thomson. 0 professor reafirma que o modelo de Thomson permitia entender os ângulos pequenos. Em seguida, $\mathbf{P}_{\boldsymbol{0}}$ solicita aos alunos que proponham um modelo de átomo que fosse capaz de explicar tanto os desvios com ângulos pequenos ou nulos (algo explicado pelo modelo de Thomson) como os desvios com ângulos grandes (algo não explicado pelo modelo de Thomson).

\section{Situação $\underline{S} \underline{7}\left(\underline{I}_{3}\right)$}

$\mathrm{Na} 3^{\text {a }}$ implementação do curso $\left(\mathbf{I}_{3}\right)$, conforme o diálogo que se segue, os alunos de um dos grupos discutiam com o professor $\mathbf{P}_{\mathbf{3}}$ O fato dos resultados do experimento de Geiger-Marsden não concordarem com a predição que haviam feito:

$\mathbf{A}_{10}\left(\mathbf{I}_{3}\right)$ : Eu pensava que não se desviava tanto.

$\mathbf{P}_{3}$ : E por que se desvia tanto?

$\mathbf{A}_{10}\left(\mathbf{I}_{3}\right)$ : Porque é sólido, e rebate.

$\mathbf{P}_{3}$ : Qual a pergunta?

$A_{12}\left(I_{3}\right)$ : Não, não rebate, não toca.

$A_{10}\left(I_{3}\right)$ : Não, não toca.

$\mathbf{P}_{3}$ : Não, não rebate.

$A_{11}\left(I_{3}\right): A h$ ! Não, é verdade.

$A_{10}\left(I_{3}\right)$ : Claro, é verdade.

$\mathbf{P}_{3}$ : Nenhuma rebate, não toca.

Como podemos perceber, na falta de uma explicação para os grandes desvios das partículas alfa no experimento de Geiger-Marsden (simulação Rutherford Scattering), a aluna $\mathbf{A}_{10}\left(\mathrm{I}_{3}\right)$ recorre à noção de solidez, algo que só teria sentido em interações entre corpos macroscópicos, e não em interações que ocorrem em um nível microscópico. Assim, a percepção de colisões em corpos sólidos acaba sendo considerada ao tentar encontrar uma explicação para o resultado observado com o uso da simulação. 
As intervenções da aluna $\mathbf{A}_{12}\left(\mathbf{I}_{3}\right)$ e do professor $\mathbf{P}_{\mathbf{3}}$ são mais restritas em afirmar que não haveria uma colisão e contato. No entanto, o diálogo avança um pouco mais quando a professora $\mathbf{P}_{\mathbf{1}}$ se aproxima do grupo e participa da discussão:

$\mathbf{P}_{3}$ : Elas pensavam que tocaria, e não tocam.

$\mathrm{P}_{1}$ : Ok.

$A_{11}\left(I_{3}\right)$ : Mas não tocam.

$\mathbf{P}_{1}$ : Ok. Por quê?

$A_{11}\left(I_{3}\right)$ : Porque são dois positivos.

$\mathbf{P}_{1}$ : Ok. Mas, tranquila. Você pensava que tocaria. Por quê? Porque estava imaginando as bolas de gude que tocam e retrocedem. Ok? Agora já sabem que há uma interação, ok? Que é entre duas cargas, e resulta que quanto mais próximas, maior é a interação, maior, maior, de maneira que chega um momento que ficam tão próximas que é impossível, como dois ímãs, que tenta tocar dois polos posi... dois nega... Ai! Dois nortes ou dois suis, e não pode, é impossível. Ok?

$\mathbf{P}_{3}$ : E agora, sua pergunta, sobre porque se desviam tanto.

$A_{12}\left(I_{3}\right)$ : Porque... porque é muito forte. E assim, desviam.

$\mathbf{P}_{3}$ : E por que no modelo de antes não é tão forte? No modelo de antes não é tão forte a interação, pois ela não se desvia tanto. Não?

$A_{11}\left(I_{3}\right)$ : Não.

$\mathbf{P}_{3}$ : Desviava um pouco, ao contrário aqui, se desvia muito. Portanto...

[Trecho não compreensível]

$\mathbf{A}_{12}\left(\mathbf{I}_{3}\right)$ : Antes era uma nuvem. E aqui, está tudo mais concentrado. Não?

$\mathbf{P}_{3}$ : Então a interação como é?

$A_{12}\left(I_{3}\right)$ : Mais forte.

$\mathbf{P}_{3}$ : Muito mais forte.

$\mathrm{A}_{10}\left(\mathrm{I}_{3}\right)$ : Aqui há mais massa.

$\mathbf{P}_{3}$ : Não, não. Não tem a ver com a massa. São duas cargas.

$\mathbf{A}_{12}\left(I_{3}\right)$ : Antes era uma nuvem...

$\mathbf{P}_{3}$ : As massas são iguais.

$A_{10}\left(I_{3}\right)$ : Antes estava mais...

$\mathbf{P}_{3}$ : Claro, antes, se ia próximo ao meio, uma parte compensava a outra. Entenderam? Uma parte compensava a outra. Ao contrário aqui, se vai próximo ao meio terá toda a massa, toda a carga repelindo. 
$A_{12}\left(I_{3}\right)$ : Aí não pode passar, só vai diretamente fora [Fora da direção do núcleo].

$\mathbf{P}_{3}$ : Tem toda a massa repelindo. Toda a massa repelindo... Todo o núcleo repelindo.

Conforme observamos na continuidade do diálogo, agora com a participação da professora $\mathbf{P}_{1}$, a aluna $\mathbf{A}_{11}\left(\mathbf{I}_{3}\right)$ reconhece que os desvios ocorriam por haver duas cargas positivas. $\mathbf{P}_{\mathbf{1}}$ então compara o que as alunas estavam pensando, sobre haver uma colisão, com o experimento analógico realizado. $\mathrm{O}$ experimento analógico foi utilizado anteriormente para introduzir a técnica de lançamento de projéteis e análise da trajetória após uma interação. Como o experimento analógico envolvia colisões mecânicas, havia a possibilidade dos alunos se apoiarem neste aspecto para explicar os grandes desvios de partículas alfa no experimento de Geiger-Marsden, mas os professores já previam esta possibilidade, tanto que a professora $\mathbf{P}_{1}$ faz a comparação ressaltando que agora há uma interação entre cargas elétricas.

Em seguida, $\mathbf{P}_{3}$ retorna à discussão do porquê de ocorrerem os desvios grandes, já direcionando para um novo modelo de átomo. As alunas reconhecem que há uma interação mais forte do que o esperado quando se considera o átomo de Thomson, e a aluna $\mathbf{A}_{10}\left(\mathbf{I}_{3}\right)$ insere a questão da massa. É interessante notar, que mesmo após, talvez, se dar conta que se tratava de uma interação elétrica, a aluna $A_{10}\left(I_{3}\right)$ recorre à noção de massa, que não tem relevância ao se considerar a repulsão elétrica. É possível que, pela sua forma pouco estruturada e por estar em um processo de construção, o modelo mental da aluna sobre a estrutura atômica ainda mantém uma forte ideia de algo mais diretamente perceptível, a massa, o que poderia estar associado também à própria ideia de colisão mecânica.

O professor $\mathbf{P}_{3}$, percebendo a inadequação da ideia de massa para pensar os desvios grandes das partículas alfa, redireciona o foco do diálogo para a questão da carga, e chega a uma ideia de concentração de carga e massa. Em outras situações que serão apresentadas mais à frente, $\mathbf{S}_{11}\left(\mathbf{I}_{5}\right)$ e $\mathbf{S}_{12}\left(I_{5}\right)$, a ideia de concentração de massa aparece de forma mais clara e ocupando um lugar central na explicação dos desvios com grandes ângulos. 


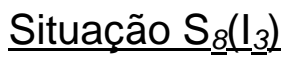

Ainda na $3^{\mathrm{a}}$ implementação do curso, ocorreu uma discussão conjunta entre $\mathbf{P}_{1}$ e os alunos da turma sobre os resultados do experimento de Geiger-Marsden não estarem de acordo com a predição baseada no átomo de Thomson. Nesta, a noção de colisão mecânica surge mais uma vez por uma aluna:

$\mathbf{P}_{1}$ : Tem as partículas alfa e o átomo que é neutro. Isso eles tinham bem claro. Thomson... Isto é, a quantidade de carga positiva na nuvem era da mesma quantidade dos elétrons. Portanto, como podia desviar? Quem tem um motivo?

$A_{8}\left(I_{3}\right):$ Porque chocam...

$\mathrm{P}_{1}:$ Por que chocam?

$A_{8}\left(I_{3}\right):$...com o átomo de Thomson.

$\mathbf{P}_{1}$ : Ok. Vão chocar, e porque chocam vão desviar. A probabilidade de chocar era pequeníssima, mas pequeníssima falo em milhões, uma para milhões e milhões. Os elétrons são pequeniníssimos. As partículas alfa eram muito grandes, sim? Aqui tem uma formiga, nem a percebe. Me entende? A partícula alfa para aquele elétron, ridículo o elétron, nem percebe o choque. Entenderam a ideia? Os elétrons são muito mais pequenos que as partículas alfa. Por choques, difícil de explicar, pois eram maiores.

$\mathbf{A}_{8}\left(I_{3}\right)$ : Porque a nuvem possui a mesma carga das partículas alfa, e as desvia.

$\mathbf{P}_{1}:$ Por choque?

$\mathbf{A}_{8}\left(\mathbf{I}_{3}\right)$ : Repelia. Bom...

No trecho acima percebemos que para a aluna $\mathbf{A}_{\delta}\left(I_{3}\right)$, a partícula alfa voltaria com ângulos grandes por se chocar com o átomo de Thomson. Ao se contrapor a esta ideia, $\mathbf{P}_{\mathbf{1}}$ limita-se a afirmar que a probabilidade da partícula alfa encontrar um elétron em sua trajetória era muito pequena, e que mesmo se encontrasse, não sofreria desvios por este encontro. Ainda que esta informação não esteja incorreta, o aspecto que talvez seja mais relevante no comentário da aluna é uma possível colisão entre a partícula alfa e a "superfície" do átomo de Thomson. Isto acaba não sendo contemplado na argumentação da professora. Em seguida, a aluna conclui que a nuvem (parte positiva do átomo) teria a mesma carga da partícula alfa, algo que já era apresentado na definição do átomo de Thomson, não chegando a uma ideia de concentração de carga positiva e ao que estava presente no discurso da professora: uma interação com algo no interior do átomo. 
Assim, ao que parece a ideia de colisão com o átomo é parcialmente confrontada, resultando também em uma superação parcial de tal ideia. Se por um lado a aluna pode ter chegado à conclusão de que não havia uma colisão mecânica, mas uma repulsão entre cargas de mesmo sinal, por outro lado a aluna permanece se referindo ao átomo, e não a algo em seu interior.

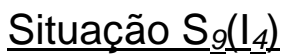

Na 4⿳亠丷a implementação $\left(\mathbf{I}_{4}\right)$, a Ideia de colisão mecânica também surge ao se discutir os desvios com ângulos grandes:

$\mathbf{P}_{2}$ : Como explicaria aqueles, aqueles desvios com ângulos tão grandes?

$\mathbf{A}_{2}\left(\mathbf{I}_{4}\right)$ : Porque rebatem.

$\mathbf{P}_{1}$ : Rebatem em quê? Nos elétrons?

$\mathbf{P}_{2}$ : Ele diz que rebatem na placa. [fala para $\boldsymbol{P}_{1}$ ] A placa seria como o átomo. [fala para $\mathbf{A}_{3}\left(\mathbf{I}_{4}\right)$ ]

$\mathbf{A}_{3}\left(I_{4}\right)$ : Tem a placa, as partículas encontram a placa.

$\mathbf{P}_{1}$ : A placa são os átomos. Estamos falando de átomos e os átomos estão dentro da placa. Quando falamos de placa, falamos de átomos. Recordem que o átomo de Thomson é uma nuvem. Em teoria, atravessam a placa. Sim? O que estou tentando é: se tudo é uma nuvem, não é possível que haja ângulos tão grandes. Uma explicação possível, uma explicação possível é o que acabam de dizer, que se chocam com os elétrons. Já veremos o que ocorre. Uma outra explicação?

$\mathbf{A}_{4}\left(\mathbf{I}_{4}\right)$ : Se chocam com a lâmina de sulfeto...

$\mathbf{P}_{3}$ : Não, elas são absorvidas. Você fala a lâmina de sulfeto de zinco?

$\mathbf{A}_{4}\left(\mathrm{I}_{4}\right): \operatorname{Sim}$

$\mathbf{P}_{3}$ : Não. São absorvidas e não podem rebater.

$\mathbf{A}_{4}\left(\mathbf{I}_{4}\right):$ Rebatem e voltariam, acho.

$\mathbf{P}_{3}$ : Não. É certo que não podem rebater.

$P_{1}$ : Isso é impossível.

$\mathbf{A}_{6}\left(\mathbf{I}_{4}\right)$ : Seria então com os elétrons, não?

$\mathbf{P}_{1}$ : Ok. Vamos esclarecer sobre os elétrons. Ok? Os elétrons, por exemplo, podem imaginar como umas moscas que avançam sobre um caminhão. O caminhão é uma partícula alfa. Há uma mosca que vai em sentido contrário e tenta frear o caminhão, mas o caminhão evidentemente suporta a mosca, porque é muito maior. Pensem que uma partícula alfa tem dois nêutrons e dois prótons. Ok? E, além disso, sabem que sua massa é mais de mil vezes maior. Portanto, ainda que haja a coisa tão pequena como o elétron, a grande partícula alfa nem nota. Passa direto. De acordo? Sim? Entenderam a ideia um pouco? Os elétrons... é verdade que 
poderiam frear um pouco, frear não, desviar uma partícula positiva, a atrairia. Ok? Mas esta atração é mínima frente à velocidade que possuem estas partículas alfa, a esta energia que possuem. De acordo? Ok? Imaginem isso, que é como um projétil. Imaginem que disparam um tiro. A bala não é freada pelo ar muito, um pouco, mas praticamente nem mesmo o efeito de uma mosca a impede de continuar a sua trajetória. Sim? Ok? Portanto, o que está acontecendo? Ok? Podemos explicar os grandes desvios pelo modelo de Thomson?

Muitos alunos: Não.

Percebemos no diálogo anterior que os alunos apresentam várias possibilidades para o que ocasiona os desvios grandes, todas envolvendo alguma colisão: com a lâmina de ouro, com a lâmina de sulfeto de zinco, ou mesmo com os elétrons no interior do átomo.

Os professores $\mathbf{P}_{\mathbf{1}}, \mathbf{P}_{\mathbf{2}}$ e $\mathbf{P}_{\mathbf{3}}$ argumentam a impossibilidade de cada uma das colisões. Primeiro comentam que a lâmina de ouro é composta por átomos, os quais, no momento de realização do experimento histórico de Geiger-Marsden, eram compreendidos segundo o modelo atômico de Thomson. A professora $\mathbf{P}_{\mathbf{3}}$ utiliza ainda uma metáfora que vinha sendo utilizada com frequência a partir da $3^{a}$ implementação $\left(\mathbf{I}_{3}\right)$, em que o átomo de Thomson era considerado como uma nuvem e, assim, as partículas alfa o atravessariam. Após, em relação à lâmina de sulfeto de zinco, que era utilizada no experimento de Geiger-Marsden para permitir verificar os desvios das partículas alfa a partir de centelhamentos, os professores $\mathbf{P}_{\mathbf{1}}$ e $\mathbf{P}_{\mathbf{3}}$ afirmam que a partícula alfa é absorvida por esta, não sendo refletida. Por fim, a professora $\mathbf{P}_{\mathbf{1}}$ comenta que uma colisão mecânica entre uma partícula alfa e algum elétron no interior do átomo não seria suficiente para provocar os grandes desvios devido às massas da partícula alfa e de um elétron. Uma analogia é utilizada, em que a partícula alfa é comparada a um caminhão e o elétron é comparado a uma mosca. Cabe destacar que ainda que em níveis microscópicos não tenha sentido pensar em uma colisão mecânica, em nossa avaliação a argumentação da professora, baseada em uma analogia, se apresenta como adequada para rejeitar a possibilidade dos desvios serem provocados por colisões com elétrons. No entanto, o uso da analogia não extinguiria a necessidade de uma explicação que trouxesse a ideia de que os desvios no mundo microscópico que ocorrem na interação da partícula alfa com o átomo são devidos uma repulsão elétrica, e não por colisões. 
Erros associados à noção de colisão e massa também ocorreram nas implementações do curso no contexto paulista, conforme destacado nas situações $\mathbf{S}_{10}\left(I_{5}\right), \mathbf{S}_{11}\left(I_{5}\right)$ e $\mathbf{S}_{12}\left(I_{5}\right)$ que se seguem:

\section{Situação $\mathrm{S}_{10}\left(\underline{I}_{5}\right)$}

No uso da simulação do experimento de Geiger-Marsden (Rutherford Scattering), o professor $\mathbf{P}_{5}$ dialoga com um grupo de alunos sobre uma das questões da atividade (5A, disponível no Apêndice $B$ ), a qual perguntava em que ângulos deveriam ser colocados o visor do experimento para se observar o maior número de centelhamentos possíveis, considerando o modelo de Thomson:

$\mathbf{P}_{5}$ : Então... Onde que eu coloco o visor pra pegar essas partículas que atravessam?

$A_{3}\left(I_{5}\right)$ e $A_{3}\left(I_{5}\right)$ : No meio.

$\mathbf{P}_{5}$ : Coloco aqui, por exemplo? [aponta para a região de ângulos pequenos] Coloco aqui, por exemplo? [aponta para uma região de ângulos grandes] Aqui? [aponta novamente para a região de ângulos pequenos]

$A_{2}\left(I_{5}\right)$ e $A_{3}\left(I_{5}\right): S i m$.

$A_{1}\left(I_{5}\right)$ : No meio.

$\mathbf{P}_{5}$ : Aqui é no meio? No meio é aqui? [fala apontando para a região de ângulos pequenos]

$A_{1}\left(I_{5}\right): \operatorname{Sim}$.

$\mathbf{P}_{5}$ : Ok. Isso aqui [aponta para o visor] pode se mover com ângulos. Ângulos pequenos estão aqui [indica a região], e ângulos grandes são esses aqui, acima [indica a outra região]. Maiores. Então você poderia dizer...

$\mathbf{A}_{2}\left(\mathbf{I}_{5}\right)$ : Mesmo batendo aqui primeiro [indica a lâmina de ouro] eles podem refletir aqui? [aponta para a região de ângulos pequenos]

$\mathbf{P}_{5}$ : Aí você tem que pensar... a partícula... Olha ali para aquele átomo, ali. [aponta para uma imagem que representa um mapa de trajetórias das partículas alfa atravessando o átomo de Thomson] A partícula alfa está batendo naquele átomo e voltando?

$A_{1}\left(I_{5}\right)$ : Não.

$\mathrm{A}_{2}\left(\mathrm{I}_{5}\right)$ : Não, tá sem... [palavra não compreensível]

$\mathbf{P}_{5}$ : Isso aí, essa folha de ouro, é como se fosse um vidro pra luz, né?

$\mathrm{A}_{2}\left(\mathrm{I}_{5}\right)$ : Aqui passa do mesmo jeito?

$\mathbf{P}_{5}$ : Passa do mesmo jeito.

$\mathbf{A}_{2}\left(\mathbf{I}_{5}\right)$ : Entendi. 
Conforme observamos, quando o professor $\mathbf{P}_{5}$ questiona um dos alunos sobre a posição em que deveria ser colocado o visor para que se observasse 0 maior número de centelhamentos, o aluno $\mathbf{A}_{2}\left(\mathbf{I}_{5}\right)$ questiona se chegariam partículas no outro lado da lâmina de ouro, na região de ângulos pequenos, mesmo com as partículas alfa batendo na lâmina de ouro. É possível que o aluno estivesse se referindo a uma suposta colisão das partículas alfa com a lâmina, semelhante ao que seria observado se objetos macroscópicos fossem lançados contra uma lâmina de ouro. Mais uma vez, a ideia de colisão parece sustentar o que é apresentado. $O$ professor $\mathbf{P}_{5}$ utiliza uma imagem presente no roteiro para explicar que as partículas alfa atravessariam a lâmina quando se considera o modelo de Thomson. Tal imagem, que é apresentada na Figura 23, foi utilizada nas duas últimas implementações na Catalunha $\left(\mathbf{I}_{3}\right.$ e $\left.\mathbf{I}_{4}\right)$ e nas implementações em São Paulo $\left(\mathbf{I}_{5}\right.$ e $\left.\mathbf{I}_{6}\right)$. A imagem era apresentada nas exposições dos professores e em uma questão (4a, disponível no Apêndice B) que envolvia uma predição.

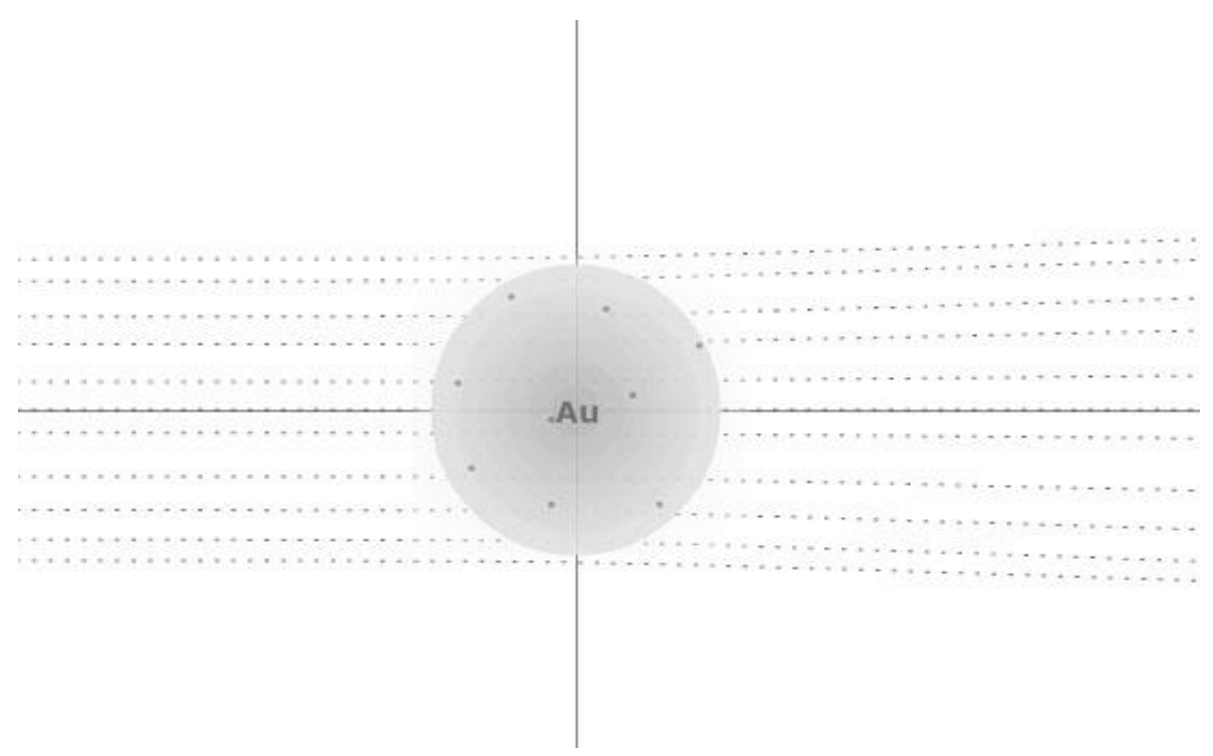

Figura 23. Representação das trajetórias das partículas alfa lançadas em direção a um átomo de ouro, segundo o modelo atômico de Thomson.

Como se pode perceber no diálogo, o professor $\mathbf{P}_{5}$ mostra a imagem, e após utiliza uma analogia em que compara a partícula alfa atravessando a lâmina de ouro com a luz atravessando um vidro. A ideia que possivelmente estaria por detrás do comentário do aluno $\mathbf{A}_{2}\left(\mathbf{I}_{5}\right)$, entretanto, parece ter ficado em segundo plano, dando lugar à explicação pela analogia. 
Conforme podemos observar na próxima situação apresentada, que ocorreu em um momento posterior da mesma implementação, o mesmo aluno retomará a ideia de uma possível reflexão das partículas alfa na lâmina de ouro.

\section{Situação $\mathrm{S}_{11}\left(\underline{I}_{5}\right)$}

O diálogo que se segue, que também ocorreu na 5aimplementação do curso (I5), envolveu uma discussão sobre a inadequação do modelo de Thomson para explicar os desvios com grandes ângulos no experimento de Geiger-Marsden:

$\mathbf{P}_{4}$ : Pra ter um desvio grande, o que devia acontecer?

$\mathbf{A}_{4}\left(\mathbf{I}_{5}\right)$ : Ali no desenho só tem trajetória reta. [aponta para o desenho com o mapa das trajetórias, o mesmo apresentado na Figura 23] Não mudou de ângulo.

$\mathbf{P}_{4}$ : Então tá vendo que o modelo não explica esses desvios grandes. Então precisa pensar em um outro modelo. Não é isso? Se você fez o experimento, a ideia é aquela [aponta para o desenho com o mapa das trajetórias], não tem desvio grande. E aí você tá vendo um desvio enorme aí, quase... mais de 90 graus, 120 graus, aí. Tem um desvio enorme que o modelo não prevê. O que tá acontecendo? Então, como se explica esse desvio? De uma partícula alfa massiva comparada com a massa do elétron, por exemplo, e ele sendo desviada dessa maneira. Sendo ricocheteada dessa maneira.

$A_{4}\left(I_{5}\right): 0$ átomo...

$\mathbf{P}_{4}$ : Mas o que tem lá dentro que faz isso? Não pode ser isso. [aponta novamente para o desenho com o mapa das trajetórias] Senão...

$A_{2}\left(I_{5}\right)$ : Não é a lâmina?

$\mathbf{P}_{4}$ : Não, você está olhando o átomo, tá no interior da lâmina, o átomo é parte da lâmina. É isso que você está olhando lá. [aponta novamente para o desenho com o mapa das trajetórias] A lâmina é feita de átomo. E aí você olhou que... você jogou uma partícula alfa lá e ela voltou. Então, como que você explica agora?

No diálogo, na tentativa de encontrar uma explicação pra os grandes desvios da partícula alfa, o aluno $\mathbf{A}_{2}\left(\mathbf{I}_{5}\right)$ retoma a ideia de que a partícula alfa colidiria na lâmina de ouro, sendo refletida. Como se percebe, tal ideia que possivelmente vinha da percepção cotidiana sobre colisões, é contraposta pelo professor a partir de uma exposição clara de que a lâmina de ouro era composta por átomos, sendo que estes, até aquele momento, eram descritos pelo modelo de Thomson. A emersão dessa ideia, assim como a forma como aparentemente foi superada, é semelhante ao ocorrido no contexto catalão, apresentado na situação $\underline{S_{\underline{b}}} \underline{\underline{1}}$. 
Além do erro apresentado pelo aluno $\mathbf{A}_{2}\left(I_{5}\right)$, vale destacar a inserção do professor $\mathbf{P}_{4}$ em sua explicação, de uma grandeza física que não teria uma relevância tão grande no entendimento dos desvios: a massa. Isso será tratado com mais detalhes à frente, quando analisamos os obstáculos didático-pedagógicos associados a alguns obstáculos epistemológicos.

Por fim, apresentamos uma última situação na qual, a nosso ver, também atuam obstáculos epistemológicos da percepção direta relacionados à ideia de colisão:

\section{Situação $S_{12}\left(1_{5}\right)$}

A ideia de colisão não esteve restrita à compreensão da interação da partícula alfa com o átomo de Thomson ou com a lâmina de ouro do experimento de Geiger-Marsden, mas surgiu também em uma análise da interação em uma escala ainda menor, já envolvendo a noção de um átomo nuclear. Após as discussões sobre o experimento de Geiger-Marsden, o curso abordava a noção de átomo nuclear e, considerando esta noção, abordava a interação das partículas alfa com o núcleo atômico. Em uma questão ( $6 \mathrm{~A}$, disponível no Apêndice $\mathrm{B}$ ) era solicitado que fosse feito o desenho das trajetórias de seis partículas alfa que se deslocavam em direção a um núcleo atômico. O aluno $A_{7}\left(I_{5}\right)$ desenhou em seu dossiê as trajetórias tocando o núcleo atômico, conforme pode ser observado na Figura 24:

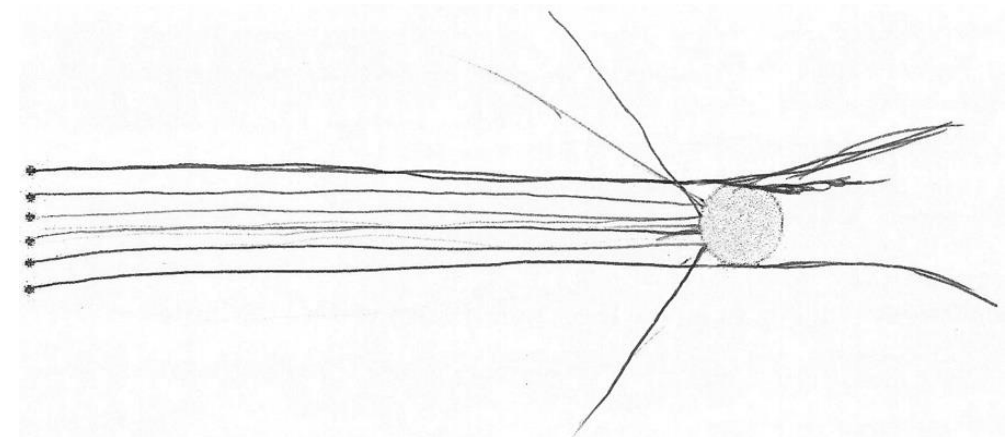

Figura 24. Desenho feito pelo aluno $\mathbf{A}_{-}\left(\mathbf{I}_{5}\right)$ para representar a interação entre partículas alfa e um núcleo atômico.

Ao observar o desenho, o professor $\mathbf{P}_{5}$ inicia o seguinte diálogo com o aluno:

$\mathbf{P}_{5}$ : Você desenhou a trajetória tocando o núcleo?

$A_{7}\left(I_{5}\right): \operatorname{Sim}$.

$\mathbf{P}_{5}$ : Mas e a simulação? Comparou com a simulação? 
$A_{-}\left(I_{5}\right)$ : A simulação tá errada. Pra desviar tem que tocar, tem que bater. É como... como uma bola de sinuca, desvia quando choca.

$\mathbf{P}_{5}$ : Sempre tem que tocar? E a força elétrica?

$A_{7}\left(I_{5}\right)$ : É que... O núcleo é uma concentração de massa...

$\mathbf{P}_{5}$ : Sim, tem uma concentração de massa. Mas tem carga elétrica. A partícula alfa é o quê? Positiva. E o núcleo?

A-( $\left(I_{5}\right)$ : Positivo?

$\mathbf{P}_{5}$ : Sim. Tem repulsão então, não?

$A_{-}\left(I_{5}\right)$ : É, tem repulsão.

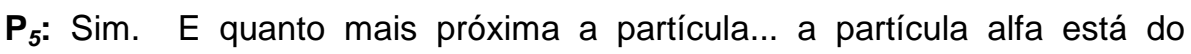
núcleo, maior ou menor é a força de repulsão?

$A_{7}\left(I_{5}\right): E ́$

$\mathbf{P}_{5}$ : A força é inversamente proporcional...

$A_{-}\left(I_{5}\right)$ : Quanto mais perto, maior é a força?

$\mathbf{P}_{5}$ : Sim. Então, a partícula vai ser repelida, e quanto mais perto chegar, mais próximo estiver, maior é a força. Agora, pode desviar sem tocar. Entendeu?

$A_{7}\left(I_{5}\right):$ Ah, tá. Entendi. Então se tem repulsão das cargas, desvia sem tocar.

$\mathbf{P}_{5}$ : Sim. Se tem repulsão, há desvio sem contato.

$\mathbf{A}_{7}\left(\mathbf{I}_{5}\right)$ : Entendi.

Conforme podemos perceber, o aluno justifica o seu desenho, em que as trajetórias tocavam o núcleo, afirmando que desvios seriam provocados somente por colisões, e utiliza como exemplo a colisão entre bolas em um jogo de sinuca. Com este exemplo, notamos claramente a influência na interpretação de um fenômeno do mundo microscópico, da percepção ingênua do cotidiano de objetos que podem ser observados a olho nu. Neste caso, mesmo o uso da simulação parece não ter desestabilizado a ideia por detrás do erro do aluno, ao ponto deste afirmar que o que estava sendo apresentado pela simulação estava errado. Apesar da convicção do aluno demonstrada em sua afirmação sobre a simulação, aparentemente este reconheceu o erro prontamente quando o professor $\mathbf{P}_{4}$ retomou a noção de carga elétrica, e afirmando que ambos, núcleo e partícula alfa possuíam carga elétrica.

Uma vez apresentadas esta e as situações anteriores relacionadas à ideia de colisão, alguns aspectos podem ser ressaltados. Conforme expusemos, em 
todas as situações os alunos apresentam uma interpretação incorreta dos resultados e dos fenômenos envolvidos, por tentarem aplicar a ideia de colisão que surge na experiência cotidiana em que interações que resultam em desvios, em grande parte envolvem colisões com contato.

Assim, tal ideia de colisão envolvendo corpos macroscópicos, que é útil para entender diversas situações cotidianas, atua como um obstáculo epistemológico à compreensão de interações no mundo microscópico. Como pudemos observar, tal obstáculo foi frequente, se manifestando em muitas situações.

Na situação $\left.\underline{S}_{5} \underline{I}_{1}\right)$ a ideia surge no momento em que deveria ser feita uma predição sobre o que ocorria quando partículas alfa fossem lançadas contra o átomo de Thomson, em um momento anterior ao uso da simulação Rutherford Scattering. Como o átomo em questão era de um elemento correspondente a um material que na natureza é encontrado na forma sólida (ouro), as trajetórias das partículas alfa indicavam uma colisão destas com a superfície do átomo de Thomson, sem que atravessassem o átomo. A ideia de solidez acaba reforçando e, de certa forma, se integra ao obstáculo epistemológico relacionado às colisões.

Já na situação $\underline{S}_{10}\left(\underline{1}_{5}\right)$, o obstáculo atuou no momento em que o professor $\mathbf{P}_{5}$ discutia com os alunos de um grupo o resultado que era esperado para 0 experimento de Geiger-Marsden representado na simulação Rutherford Scattering. Conforme expomos, o aluno $\mathbf{A}_{2}\left(\mathbf{I}_{5}\right)$ questiona a afirmação de que partículas alfa chegariam, em sua maioria, com desvios nulos ou quase nulos, já que para ele refletiriam na lâmina de ouro. Posteriormente, na situação $\underline{S}_{10} \underline{\underline{l}} \underline{4}$, o mesmo aluno apresenta a suposta colisão das partículas alfa com a lâmina de ouro para explicar os desvios grandes verificados após o uso da simulação. A mesma explicação para os desvios com ângulos grandes é apresentada pelo aluno $\mathbf{A}_{3}\left(\mathbf{I}_{4}\right)$ na situação $\left.\underline{S_{g}} \underline{\underline{I}} \underline{I}_{4}\right)$. Nesta situação, uma possível colisão das partículas alfa com a lâmina de sulfeto de zinco e uma possível colisão com os elétrons no interior do átomo, são apresentadas por outros alunos. Como podemos perceber nestas situações, a ideia de solidez implícita ao material da lâmina parece atuar na emersão do obstáculo.

A última situação apresentada, $\underline{S}_{12}\left(\underline{I}_{5}\right)$, envolvia o uso da simulação Up Close Rutherford Scattering, que simulava o comportamento de partículas alfa se deslocando próximo ao núcleo atômico (modelo atômico de Rutherford). Antes de utilizar a simulação, deveria ser feita uma predição das trajetórias das partículas alfa, 
e o aluno $A_{-}\left(I_{5}\right)$ as desenha tocando o núcleo, representando uma colisão com o núcleo. Na fala do aluno, fica clara a atuação do obstáculo epistemológico, uma vez que este, inclusive, utiliza exemplos em que a ideia elencada por ele é aplicável. Ressalta-se também, a rejeição do aluno aos resultados obtidos virtualmente com a simulação frente à ideia de colisão que ele já possuía.

Pelos diálogos apresentados, aparentemente a superação do obstáculo ocorreu em algumas das situações. A abordagem necessária ao professor e alunos para a superação do obstáculo epistemológico foi semelhante em função da forma como se manifestava: em colisões entre as partículas alfa com o átomo de Thomson, se rediscutia o modelo atômico de Thomson; em colisões entre as partículas alfa e a lâmina de ouro, se recorria à predição sobre a interação com o átomo de Thomson que era antes discutida e era reforçado o fato de que a lâmina de ouro era composta por átomos; e em colisões entre as partículas alfa e o núcleo atômico (átomo de Rutherford), se destacava a carga elétrica das entidades envolvidas na interação.

Sobre a relação mais direta entre este obstáculo epistemológico e as simulações utilizadas, ao contrário do outro obstáculo da percepção direta que apresentamos, neste as simulações aparecem como um terreno muito fértil para a emersão do obstáculo. Como percebemos, o obstáculo atuou no uso das simulações na interpretação dos fenômenos nelas representadas, e também na interpretação dos resultados nelas obtidas, o que inclusive em alguns casos, como vimos na descrição da situação $\underline{S}_{12}\left(I_{5}\right)$, pode culminar na não aceitação dos resultados virtuais obtidos. A questão do raciocínio analógico envolvido no uso das simulações também fica claro nestas situações: as entidades envolvidas nas simulações, como a lâmina de ouro e o átomo de ouro, quando vistas em uma perspectiva macroscópica, envolvem propriedades como impenetrabilidade e dureza, as quais não possuíam relevância no mundo microscópico investigado. Aliado a isso, os fenômenos representados nas simulações, quando relacionados com a dinâmica perceptível no cotidiano, remetiam à ideia de colisão. Assim, em um raciocínio analógico inesperado, aspectos do análogo (simulação) e do objeto de estudo que não se aplicariam ao que se analisava, acabaram sendo valorizadas, e se não fossem alvo de atenção dos professores, levariam à formação de modelos 
mentais incompatíveis com o esperado, ou seja, incompatíveis com os modelos conceituais envolvidos.

Assim, em relação à evolução da aprendizagem, pelo que comentamos até aqui, nos parece claro que o tratamento adequado e a superação do obstáculo epistemológico se faz necessário para que se possa avançar no processo de aperfeiçoamento dos modelos mentais dos alunos, e para que se obtenha sucesso no uso das simulações computacionais envolvidas.

\subsection{2- Obstáculos da metáfora, da analogia e da imagem}

Outra categoria de obstáculos epistemológicos que reconhecemos envolve o uso de metáforas ou analogias e o uso de imagens. Estes obstáculos, que ocorreram com uma menor frequência se comparado aos anteriormente apresentados, foram divididos em dois subgrupos: um relacionado à atribuição de propriedades inesperadas ao objeto apresentado em uma situação de uso de uma metáfora, e outro subtipo relacionado à leitura de imagens.

\section{- Atribuição de propriedades ao objeto da metáfora: obstáculo verbal}

Neste subgrupo de obstáculo, a metáfora utilizada na apresentação ou discussão de um determinado objeto de estudo acaba gerando uma interpretação incorreta do objeto de estudo. Conforme pode ser visto na situação $\left.\underline{S}_{13} \underline{I}_{2} \underline{L}\right)$ a seguir descrita, um obstáculo deste tipo ocorreu em uma situação em que se utilizava uma simulação computacional.

\section{$\underline{\text { Situação } S_{13}\left(1_{2}\right)}$}

$\mathrm{Na} 2^{\mathrm{a}}$ implementação do curso $\left(\mathbf{I}_{2}\right)$, que ocorreu no contexto catalão, ao discutir com um grupo de alunos sobre a interação entre partículas alfa e o átomo de Thomson e sobre a predição do que deveria ser esperado na simulação do experimento de Geiger-Marsden (Rutherford Scattering), o professor $\mathbf{P}_{\mathbf{3}}$ utiliza uma metáfora na tentativa de explicar o motivo pelo qual as partículas alfa atravessariam o átomo:

$\mathbf{P}_{3}$ : É. Imagine o átomo como uma nuvem. É semelhante a uma nuvem.

$\mathbf{A}_{8}\left(\mathrm{I}_{2}\right)$ : Como uma nuvem? Seria como um fluido?

$\mathbf{P}_{3}$ : Sim. Como um fluido, que pode ser atravessado.

$A_{8}\left(I_{2}\right)$ : O átomo deforma? 


\section{$\mathbf{P}_{3}$ : Deforma? Como?}

$A_{8}\left(I_{2}\right)$ : Quando um objeto passa no ar, em um fluido... Se for como um fluido, o átomo deforma. O objeto no ar faz... faz... tornados, pequenos tornados.

$\mathbf{P}_{3}$ : Não. Atravessa... Você está falando de vórtices?

$\mathbf{A}_{8}\left(\mathbf{I}_{2}\right)$ : É, acho que é isso.

$\mathbf{P}_{3}$ : Não. Imagine que o átomo, o átomo de Thomson, é como uma nuvem, como um fluido, no sentido que consegue atravessar. $O$ átomo não é um fluido, atravessa como se fosse em um fluido. Por exemplo, bolas lançadas no ar. O átomo de Thomson é uma... veja a definição. Onde está? Aqui. [aponta para a descrição do átomo de Thomson disponível no roteiro da atividade] Diz que é uma esfera positiva com cargas negativas, ok? $\mathrm{O}$ átomo é uma esfera que pode ser penetrada pela partícula alfa, mas não deforma. Somente atravessa, como em um fluido, mas não é um fluido.

$A_{8}\left(I_{2}\right):$ Ok. Ok.

$\mathbf{P}_{3}$ : Entendeu?

$\mathbf{A}_{\boldsymbol{8}}\left(\mathbf{I}_{2}\right)$ : Sim. Atravessa, mas o átomo não deforma. Não é um fluido.

$\mathbf{P}_{3}$ : Perfeito.

Podemos observar no diálogo acima, que a metáfora do átomo de Thomson como uma nuvem, a qual foi utilizada com frequência nas implementações no contexto catalão, gerou um resultado inesperado sobre propriedades do átomo. Com base na metáfora, o aluno $\mathbf{A}_{8}\left(\mathbf{I}_{2}\right)$ pergunta se o átomo de Thomson seria como um fluido, e após a resposta afirmativa do professor $\mathbf{P}_{\mathbf{3}}$, elenca algumas características dos fluidos que não eram aplicáveis para entender a estrutura do átomo: a capacidade de se deformar facilmente e a criação de vórtices quando é atravessado por algo.

Como podemos perceber, o conhecimento que o aluno já possui sobre o termo utilizado na metáfora, neste caso os termos nuvens e fluidos, acaba sendo considerado na interpretação do objeto de estudo foco do uso da metáfora. Esta interpretação inadequada é semelhante ao descrito por Bachelard para o obstáculo verba $^{43}$. Vale destacar que, na situação apresentada, o professor reconhece o uso inapropriado de elementos da metáfora e a desconstrói, de modo a evitar que um obstáculo epistemológico se forme ou gere consequências maiores no processo de aprendizagem. Sendo assim, diríamos que o uso inapropriado da metáfora induziria ao estabelecimento potencial de um obstáculo epistemológico.

\footnotetext{
${ }^{43}$ Uma breve descrição do obstáculo verbal foi apresentada no subcapítulo 5.1 da presente tese.
} 
Algo que vale ser ressaltado é que o uso da metáfora, ainda que tenha gerado resultados inesperados, facilitava a compreensão da penetrabilidade das partículas alfa no átomo de Thomson nas implementações do curso. Entretanto, foi necessária a desconstrução da parte indesejada da metáfora de modo a permanecer nos limites de uma analogia: da comparação implícita envolvida na metáfora, partiuse para uma comparação mais explícita evidenciando o que havia de semelhante/parecido ou não entre uma nuvem e um átomo de Thomson.

Em relação ao uso da simulação, ainda que na situação analisada não estivesse envolvida diretamente no surgimento do obstáculo, vale destacar que ela não seria suficiente, por si só, para superar o obstáculo. Além disso, a própria interpretação da simulação e dos resultados nela obtida poderia ser prejudicada.

\section{- Leitura guiada pela imagem conhecida}

Outro subgrupo de obstáculo epistemológico que classificamos como integrante da categoria dos obstáculos da metáfora, analogia e da imagem está relacionado com a leitura incorreta de uma representação, baseando-se em algo já

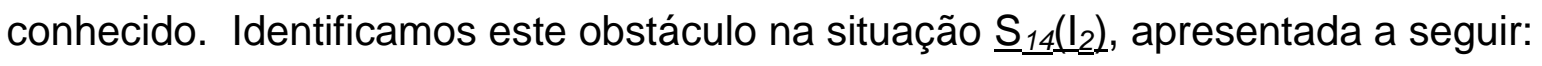

\section{Situação $\left.\mathrm{S}_{14} \underline{I}_{2}\right)$}

Na segunda implementação no contexto catalão $\left(\mathbf{I}_{\mathbf{1}}\right)$, ao utilizar a simulação do experimento de Geiger-Marsden ${ }^{44}$ (Rutherford Scattering), um grupo de alunos chegou a uma conclusão contrária àquela esperada:

$\mathbf{P}_{3}$ : Vocês. A que conclusão chegaram após utilizarem a simulação do experimento de Rutherford?
$\mathbf{A}_{1}\left(\mathbf{I}_{2}\right)$ : A predição estava correta.
$\mathbf{P}_{3}$ : Que predição?
$A_{1}\left(I_{2}\right)$ : Que a estrutura do átomo é como Thomson descrevia.
$\mathbf{P}_{3}$ : Vejamos. Você está dizendo que o experimento de Rutherford comprova o modelo atômico de Thomson?

$\mathbf{A}_{1}\left(\mathbf{I}_{2}\right)$ e $\mathbf{A}_{3}\left(\mathbf{I}_{2}\right): \operatorname{Sim}$.

\footnotetext{
${ }^{44}$ Durante as implementações na Catalunha e em São Paulo, com frequência professores e alunos se referiam ao experimento de Geiger-Marsden como experimento de Rutherford. Isto pode ser observado nas situações $S_{14}\left(I_{2}\right), S_{16}\left(I_{2}\right)$ e $S_{18}\left(I_{5}\right)$. Historicamente o experimento foi executado por Hans Geiger e Ernest Marsden, mas com a supervisão de Rutherford. Ainda que haja uma imprecisão histórica em se referir a um experimento de Rutherford, a nosso ver não há prejuízos em relação ao objetivo de discutir o experimento no curso, que era o de levar a uma construção conceitual do modelo atômico com um núcleo e a um entendimento da técnica empregada.
} 
$\mathbf{P}_{3}$ : Ok. Mas como concluíram isto?

$\mathbf{A}_{2}\left(\mathbf{I}_{2}\right)$ : No experimento vimos o modelo de Thomson.

$A_{1}\left(I_{2}\right)$ : É. Olhe, olhe a tela [aponta para a simulação na tela do computador]. O que se vê no visor é o átomo de Thomson.

$\mathbf{P}_{3}$ : Então vocês estão dizendo que no visor do experimento, Rutherford conseguia ver o átomo e este átomo seria igual ao previsto por Thomson? É isto?

$\mathbf{A}_{1}\left(I_{2}\right), \mathbf{A}_{2}\left(I_{2}\right), \mathbf{A}_{3}\left(I_{2}\right)$ e $\mathbf{A}_{4}\left(I_{2}\right):$ Sim.

$\mathbf{P}_{3}$ : Mas Rutherford não via o átomo. O que aparece no visor é o átomo?

$A_{1}\left(I_{2}\right): \operatorname{Sim}$. Não?

$\mathbf{P}_{3}$ : Não. O que está escrito no roteiro? $\mathrm{O}$ que diz sobre $\mathrm{o}$ visor do experimento?

$\mathbf{A}_{1}\left(\mathbf{I}_{2}\right)$ : Vejamos...

$\mathbf{P}_{3}$ : Diz que o visor permite identificar as partículas alfa que chegam. O que são os pontos no visor?

$A_{1}\left(I_{2}\right)$ : As partículas? As partículas alfa?

$A_{3}\left(I_{2}\right)$ : Eu pensava que eram os elétrons.

$\mathbf{P}_{3}$ : É um centelhamento. As partículas alfa chegam até uma... uma parede de sulfeto de zinco. São absorvidas e isso provoca o centelhamento. Então, com o centelhamento, pode ver se chegou uma partícula alfa.

$A_{1}\left(I_{2}\right)$ : Então o visor não é como um microscópio, em que veria o átomo?

$\mathbf{P}_{3}$ : Não. O visor permite ver onde chegam as partículas alfa.

Conforme já descrito, a simulação Rutherford Scattering era utilizada no curso para permitir que se percebesse que o átomo de Thomson era inadequado. No entanto, no diálogo acima podemos notar que os alunos $\mathbf{A}_{1}\left(\mathbf{I}_{2}\right), \mathbf{A}_{2}\left(\mathbf{I}_{2}\right), \mathbf{A}_{3}\left(\mathbf{I}_{2}\right)$ e $A_{4}\left(I_{2}\right)$ chegam à conclusão que o experimento de Geiger-Marsden confirmava que o átomo de Thomson estava correto.

Analisando a situação, percebemos que o erro foi induzido por uma leitura incorreta do layout da simulação Rutherford Scattering. Os alunos interpretavam o círculo de cor cinza com pontos verdes que fazia parte do layout da simulação (apresentado na Figura 13, e em destaque na Figura 25) como sendo uma visualização direta do átomo segundo o modelo de Thomson. Com base no que é comentado pelo aluno $A_{1}\left(I_{2}\right)$ em sua penúltima fala, o visor do experimento era entendido como um microscópio que permitia a visualização direta do átomo, e este 
átomo era visto como semelhante ao proposto por Thomson, com pontos representando os elétrons, e estes imersos em uma esfera que teria carga positiva.

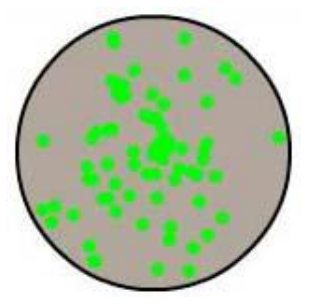

Figura 25. Círculo presente na simulação Rutherford Scattering, que era interpretado como uma visualização direta do átomo de Thomson.

Os alunos se apoiavam em uma semelhança visual entre o círculo que representava o visor do experimento com uma representação comum do átomo de Thomson $^{45}$, que inclusive era utilizada no roteiro do curso, e que é apresentada na Figura 26.

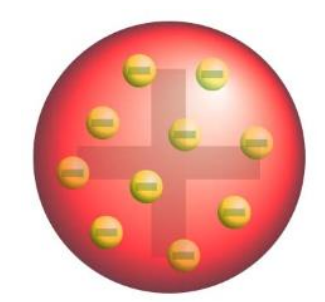

Figura 26. Representação do átomo de Thomson.

Desta situação podemos concluir que o já conhecido e que deveria ser superado (o modelo atômico de Thomson) era utilizado para interpretar um aspecto visual da simulação. Ainda que houvesse instruções no roteiro com uma descrição do experimento, a associação da imagem da simulação com uma imagem conhecida prevalecia. Assim, a ação de relacionar uma imagem conhecida que representava o átomo de Thomson com uma parte visual da simulação, acaba atuando como um obstáculo epistemológico.

Destacamos que a simples interpretação errônea de parte da simulação não seria um obstáculo epistemológico. Este é sempre uma forma de conhecer, muitas vezes associada a um conhecimento, neste caso o próprio modelo de Thomson que era estudado. Também vale destacar que, apesar do obstáculo em questão envolver uma leitura de um aspecto visual da simulação, uma mudança na simulação não conduziria necessariamente à extinção de obstáculos

\footnotetext{
${ }^{45}$ Imagem disponível em <http://commons.wikimedia.org/wiki/File:Plum_pudding_atom.svg>. Acesso em: 17 nov. 2011.
} 
epistemológicos semelhantes, em que algo conhecido viesse a guiar a leitura da simulação.

No redesenho do curso que ocorreu após a implementação $\left(\mathbf{D S}_{2}\right)$, ainda que o texto do roteiro explicasse de forma detalhada a montagem experimental, inclusive com imagens que buscavam torna claro o que era cada parte da simulação (por exemplo, a imagem apresentada no centro à direita da Figura 17), definiu-se que o professor deveria fazer uma breve exposição antes do uso da simulação, reforçando a montagem experimental representada na simulação. Isto aconteceu nas implementações posteriores, e como consequência, não mais verificamos a atuação do mesmo erro de leitura da simulação. Além disso, conforme descreveremos no subcapítulo 9.3, a imagem que representava o átomo de Thomson (Figura 26) foi substituída por outra que não se assemelha ao círculo da simulação Rutherford Scattering que representava o visor do experimento de Geiger-Marsden.

\subsection{3- Obstáculos do raciocínio limitado ou incongruente}

Um último grupo de obstáculos epistemológicos incluídos em nossa classificação envolve aqueles relacionados a um raciocínio que se apresenta como limitado ou incongruente quando gera explicações. É um obstáculo, que assim como os demais, atua impedindo que se continue a construir conhecimento e, no caso do processo de ensino-aprendizagem, prejudica a aprendizagem de um conhecimento novo.

Nesta categoria de obstáculos epistemológicos, de acordo com os dados obtidos, definimos dois subgrupos: o raciocínio limitado restrito à observação experimental e o raciocínio que extrapola os limites da conclusão. A seguir, descrevemos tais obstáculos e analisamos situações nas quais atuaram:

- Raciocínio limitado que leva a regras gerais e superficiais: conhecimento geral

Consiste em um raciocínio restrito à observação, que gera explicações mais gerais e superficiais que se prendem à descrição do facilmente observável, sem que haja um aprofundamento para entender as causas do que foi observado. Este subtipo de obstáculo do raciocínio limitado ou incongruente foi identificado na situação $\underline{\mathrm{S}}_{15}\left(\underline{I}_{3}\right)$, que é apresentada a seguir: 


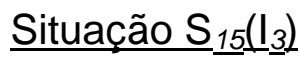

Na $3^{\text {a }}$ implementação na Catalunha $\left(\mathbf{I}_{\mathbf{3}}\right)$, os alunos de um grupo discutiam uma das questões abordadas no tópico sobre o modelo de Thomson (questão 5A, disponível no Apêndice $B$ ), a mesma questão envolvida na situação $\underline{S}_{10}\left(\underline{1}_{5}\right)$ anteriormente discutida, que consistia em uma predição sobre a interação entre as partículas alfa e o átomo de Thomson. A predição, que se baseava no mapa de trajetórias que apresentamos na Figura 23, posteriormente poderia ser verificada como válida ou não com o uso da simulação do experimento de Geiger-Marsden (Rutherford Scattering). A seguir, é apresentado diálogo:

$\mathbf{A}_{1}\left(\mathbf{I}_{3}\right)$ : Tu! Como pode ser que as partículas alfa atravessavam o átomo?
Por que elas chegaram [se refere às que chegaram no outro lado do átomo
de Thomson], senão, se rebateram, não teria por que estarem lá. Ou não?
Vêm por aqui [aponta para a imagem do mapa de trajetórias, indicando o
início da trajetória]. Aqui tem o visor. [aponta para região ao lado direito do
átomo de Thomson na imagem, se referindo ao visor do experimento de
Rhutherford] Se faz assim e não chega, é por que não atravessa
[movimenta uma caneta sobre a imagem, representando uma trajetória em
que se aproxima do átomo de Thomson e retorna]. Se atravessa é porque
ela chega. Não? $\mathbf{A}_{2}\left(\mathbf{I}_{3}\right): \operatorname{Sim}$. não?

$A_{1}\left(I_{3}\right)$ : Suponho que sim. Então, como se sabe que atravessa o átomo? Porque ela chega.

Como pode ser observado, o aluno $\mathbf{A}_{1}\left(\mathbf{I}_{3}\right)$ se limita em sua explicação a afirmar que as partículas alfa que atravessam o átomo de Thomson eram as que chegavam ao outro lado do átomo de Thomson, e as que não chegavam ao outro lado, é porque não atravessavam. Esta explicação simplista não responde o motivo pelo qual a partícula alfa pode atravessar o átomo, o que estaria relacionado à distribuição uniforme das cargas positiva e negativa no interior do átomo.

Aqui podemos ver algumas semelhanças entre a explicação do aluno e explicações próprias do obstáculo do conhecimento geral apresentado por Bachelard ${ }^{46}$. O aluno se detém ao facilmente observado, e a partir disso, apresenta uma explicação mais geral e superficial.

Logo após, quando o grupo de alunos já utilizava a simulação Rutherford Scattering e discutia o esperado para as trajetórias das partículas alfa em sua

\footnotetext{
${ }^{46}$ Uma breve descrição do obstáculo do conhecimento geral foi apresentada no subcapítulo 5.1 da presente tese.
} 
interação com o átomo de Thomson, o aluno $A_{1}\left(I_{3}\right)$ novamente retorna à questão sobre como se explicaria as partículas que atravessavam o átomo:

$A_{1}\left(I_{3}\right)$ : Como pode explicar que as partículas alfa atravessavam o átomo? Porque elas chegaram. [se refere as que são identificadas no visor quando colocado em ângulos pequenos]

[O aluno $\boldsymbol{A}_{2}\left(\mathbf{I}_{3}\right)$ gesticula discordando]

$\mathbf{A}_{2}\left(\mathbf{I}_{3}\right): \operatorname{Sim}$.

$A_{1}\left(I_{3}\right)$ : Como que não?

$\mathbf{A}_{2}\left(\mathbf{I}_{3}\right):$ Sim, chega.

$\mathbf{A}_{2}\left(\mathbf{I}_{3}\right)$ : Vão chegar as que atravessaram?

[A professora $\boldsymbol{P}_{2}$ se aproxima do grupo]

$A_{1}\left(I_{3}\right)$ : Vão chegar as que atravessaram. Se não as pode ver é porque não atravessaram. Ou não? Se você as tem aqui [aponta para a fonte de partículas alfa na simulação do experimento de Geiger-Marsden], depois as tem aqui [aponta para a região em que chegariam as partículas com desvios com ângulos pequenos], é porque atravessaram. Senão faria assim [gesticula indicando uma trajetória da partícula indo à placa e voltando].

$\mathbf{P}_{2}$ : E, como explica? Não?

$\mathbf{A}_{2}\left(\mathbf{I}_{3}\right)$ : Por que atravessa? Esta é a pergunta.

$A_{1}\left(I_{3}\right)$ : Não! Não diz "Por que atravessa?".

$\mathbf{P}_{2}$ : "Como poderia explicar que as partículas alfa atravessam o átomo?".

$A_{1}\left(I_{3}\right)$ : Por que elas chegam.

$\mathbf{P}_{2}$ : Sim, isso já se tem claro.

$\mathbf{A}_{1}\left(\mathbf{I}_{3}\right)$ : Chegam porque atravessaram.

$\mathbf{P}_{2}$ : E por que atravessam?

$A_{1}\left(I_{3}\right)$ : Não pergunta o porquê. Não pergunta. Veja bem: "Como poderia explicar que as partículas alfa atravessam o átomo?". E não: "Por que poderia explicar?"

No trecho acima, é possível perceber que a professora $\mathbf{P}_{\mathbf{2}}$, ao intervir no diálogo, tenta levar 0 aluno $\mathbf{A}_{1}\left(\mathbf{I}_{3}\right)$ a pensar no porquê das partículas alfa conseguirem atravessar o núcleo. Quando questionado sobre o porquê, o aluno reconhece que não está respondendo, e apoiando-se no próprio enunciado da questão, mantém-se em sua explicação simplificada.

Esta forma de pensar, que se restringe a descrever o simples facilmente observável e não explica o observável, chegando até mesmo a regras mais gerais, é 
um raciocínio limitado que atua como um obstáculo epistemológico. O uso da simulação Rutherford Scattering, para que fosse efetivo e resultasse em uma aprendizagem, dependia de uma predição clara do que deveria ocorrer na interação entre as partículas alfa e o átomo de Thomson. Isto não ocorre devido à atuação deste obstáculo epistemológico: a predição se limita a descrever que partículas atravessam porque chegam ao outro lado, e se não chegam ao outro lado é porque não atravessam, e assim, não permitiria uma percepção, a partir do uso da simulação, da inadequação do modelo de Thomson.

\section{- Extrapolando o limite das conclusões}

Em algumas situações verificamos que as conclusões obtidas a partir da observação de uma parte limitada de um objeto de estudo são extrapoladas para entender outras partes. Tais situações são descritas a seguir:

\section{Situação $S_{16}\left(\underline{I}_{2}\right)$}

$\mathrm{Na} 2^{\underline{a}}$ implementação no contexto catalão $\left(\mathbf{I}_{2}\right)$, verificamos uma situação em que conclusões obtidas a partir do observável na simulação Up Close Rutherford Scattering, que simulava a interação entre partículas alfa com um núcleo atômico, eram extrapoladas ao entendimento dos desvios com ângulos pequenos no experimento de Geiger-Marsden:

$\mathbf{P}_{1}$ : Vocês perceberam que o átomo de Thomson era inadequado. Ok? Um modelo com um núcleo permitia explicar os ângulos grandes. Ok? Vejamos. Nesta simulação [se refere à simulação Up Close Rutherford Scattering] analisamos a interação entre o núcleo e a partícula alfa...

$\mathbf{A}_{8}\left(\mathbf{I}_{2}\right)$ : Mas e os ângulos pequenos?

$P_{1}$ : Os ângulos pequenos?

$A_{8}\left(I_{2}\right)$ : Na simulação não chegam partículas com ângulos pequenos [se refere à simulação Up Close Rutherford Scattering]. O núcleo desvia todas. O modelo de Thomson explicava. O modelo com núcleo não explica. $\mathrm{O}$ modelo de Thomson é mais adequado, não?

$\mathbf{P}_{1}$ : Nesta simulação você tem um núcleo [se refere à simulação Up Close Rutherford Scattering]. E no experimento de Rutherford você tem somente um átomo? Somente um núcleo?

$\mathbf{A}_{8}\left(\mathbf{I}_{2}\right)$ : Tem a lâmina de ouro...

$\mathbf{P}_{1}$ : E a lâmina de ouro possui somente um átomo? Um núcleo?

$A_{8}\left(I_{2}\right)$ : Não, são vários... 
$\mathbf{P}_{1}$ : Aqui [aponta para a simulação Up Close Rutherford Scattering], só tem um núcleo. Na lâmina de ouro tem muitos, ok? Por onde vai a maioria das partículas? Lembre que o núcleo é uma parte muito pequena dos átomos. A maioria das partículas passa entre dois átomos, entre dois núcleos. Ok?

$A_{8}\left(I_{2}\right)$ : Então, o que chega com ângulos pequenos são as que passam entre dois átomos?

$\mathbf{P}_{1}$ : Sim. Ok! $\mathrm{E}$ as que desviam com ângulos grandes são as que se aproximam muito dos núcleos. Ok? Que vão em direção ao núcleo.

Do trecho anterior, percebemos que ao observar na simulação Up Close Rutherford Scattering que nenhuma partícula alfa possuía uma trajetória reta, ou seja, uma trajetória que apresentasse desvios com ângulos nulos ou pequenos, o aluno $\mathbf{A}_{\delta}\left(I_{2}\right)$ questiona se o modelo atômico nuclear era adequado, afinal os resultados obtidos na simulação do experimento histórico de Geiger-Marsden (Rutherford Scattering) mostravam muitas partículas com desvios nulos. Como podemos notar no diálogo, o raciocínio do aluno o leva a considerar o átomo de Thomson como mais adequado, afinal este permitia explicar o comportamento da maioria das partículas alfa no experimento de Geiger-Marsden.

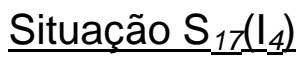

$\mathrm{Na}$ última implementação ocorrida no contexto catalão $\left(\mathbf{I}_{4}\right)$, antes mesmo dos alunos utilizarem a simulação Up Close Rutherford Scattering, e após a análise dos resultados obtidos na simulação Rutherford Scattering, em um momento em que os alunos apresentavam sua proposta do átomo, desenhando sua estrutura na lousa digital, um dos alunos questiona sobre como os ângulos pequenos seriam explicados pelo modelo atômico nuclear que estava sendo desenhado:

$\mathbf{P}_{1}$ : Pense que não está funcionando usar uma nuvem positiva. Ok? Siga... Não faça coisas que serão impossíveis.

[o aluno $\boldsymbol{A}_{7}\left(\mathrm{I}_{4}\right)$ desenha um círculo pequeno]

$\mathbf{P}_{1}$ : O que é isso?

$A_{7}\left(I_{4}\right):$ A carga positiva.

$\mathbf{P}_{1}$ : Agora, ele disse... a carga ao invés de estar em uma nuvem, ele a pôs concentrada.

$A_{7}\left(I_{4}\right)$ : Porque se a partícula alfa choca diretamente, não, não. Não vai chocar, pois não vai tocar, mas será repelida, porque se aproximasse muito acabaria se... desviaria assim.

[o aluno $\boldsymbol{A}_{\boldsymbol{T}}\left(\mathrm{I}_{4}\right)$ desenha a trajetória de partículas alfa se aproximando do núcleo e desviando] 
$\mathrm{A}_{8}\left(\mathrm{I}_{4}\right)$ : E como atravessa?

$A_{-}\left(I_{4}\right)$ : Não. Não pode passar. Simplesmente vem por aqui.

$\mathbf{P}_{1}$ : Não. Tem a carga positiva. Desenhe o átomo, desenhe o átomo. O que, o que você imagina.

[o aluno $\boldsymbol{A}_{\boldsymbol{\lambda}}\left(\mathrm{I}_{4}\right)$ desenha círculos menores ao redor do núcleo, representando os elétrons]

$A_{8}\left(I_{4}\right)$ : $E$ como explica quando é um ângulo zero em que há muitas partículas?

$\mathbf{P}_{1}$ : Porque ângulo zero, vejamos... Pense que ângulo zero não é exatamente zero. Pode ser zero como 1. Recordem que o átomo é muito pequeno. Sim? Claro, frente a uma distância pequeníssima de micro graus é como se fosse um ângulo zero porque não toca, na lâmina, um átomo. Sim?

$\mathbf{P}_{3}$ : Passa entre dois átomos... passa entre dois átomos.

$\mathbf{P}_{1}$ : Passa entre dois átomos. Sim, Sim.

O desenho que era feito pelo aluno $A_{-}\left(I_{4}\right)$ é apresentado a seguir:

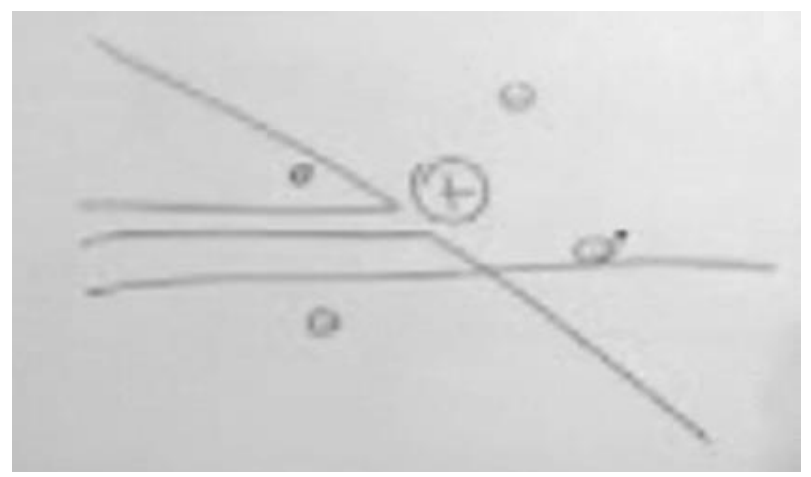

Figura 27. Desenho feito pelo aluno $\mathbf{A}_{-}\left(I_{4}\right)$ para representar o átomo nuclear e as trajetórias de partículas alfa que interagem com o átomo.

Como podemos observar no diálogo apresentado, ao observar o desenho do aluno $A_{-}\left(I_{4}\right)$, o aluno $A_{8}\left(I_{4}\right)$ questiona como as partículas alfa atravessavam para chegar, em sua maioria, com ângulos zero. Como podemos notar no desenho do aluno (Figura 27), o questionamento do aluno, ainda que seja resultado de um raciocínio que extrapola os limites dimensionais envolvidos, parece pertinente uma vez que as partículas com fator de impacto menor ou pouco maior que o raio do núcleo, não o atravessam, mas são desviados com grandes ângulos.

Podemos notar no diálogo que, em um primeiro momento, a professora $\mathbf{P}_{\mathbf{1}}$ não percebe que o aluno $A_{8}\left(I_{4}\right)$ está comparando uma visão restrita da interação com o núcleo com uma visão ampla da interação com a lâmina de ouro. Ao 
perceber que o aluno $\mathbf{A}_{8}\left(\mathbf{I}_{4}\right)$ se referia aos desvios verificados no experimento de Geiger-Marsden, o professor $\mathbf{P}_{\mathbf{3}}$ intervém afirmando que as partículas alfa com desvios pequenos passavam entre dois átomos.

\section{Situação $\mathrm{S}_{18}\left(I_{5}\right)$}

Também identificamos no contexto paulista uma situação em que ocorreu uma extrapolação do observável na interação envolvendo um núcleo, para o entendimento da interação com a lâmina de ouro do experimento de GeigerMarsden. Em um diálogo entre o professor $\mathbf{P}_{4}$ e um grupo de alunos, a aluna $\mathbf{A}_{3}\left(\mathbf{I}_{5}\right)$ questiona se nenhuma partícula alfa passava em linha reta, como o que havia sido verificado na simulação do experimento de Geiger-Marsden:

$\mathbf{A}_{3}\left(I_{5}\right)$ : Nenhum passa em linha reta que nem o experimento que a gente fez na primeira vez? [se refere ao experimento de Geiger-Marsden]

$\mathbf{P}_{4}$ : Nenhuma passa em linha que nem foi no experimento... Olha só, tem uma coisa importante, pessoal [chama a atenção dos demais alunos que compunham o grupo]. Tem uma coisa importante que agora ela falou. Nenhuma vai chegar em linha reta. Aqui, chega em linha reta? Nesse desenho que você fez aqui?

[O professor $\boldsymbol{P}_{4}$ aponta para uma das trajetórias do desenho da aluna $\boldsymbol{A}_{\mathbf{3}}\left(\mathbf{I}_{5}\right)$, que é apresentado na Figura 28]

[Trecho não compreensível]

$\mathbf{P}_{4}$ : E agora, o que vai acontecer com ela? Ela vai passar reto? [pergunta se referindo à partícula alfa e sua trajetória]

$\mathbf{A}_{2}\left(\mathbf{I}_{5}\right)$ : Ela vai passar reto.

$\mathbf{P}_{4}$ : Vai passar reto?

$\mathbf{A}_{4}\left(\mathbf{I}_{5}\right)$ : Eu acho que ela vai bater no núcleo e vai voltar.

$\mathbf{P}_{4}$ : Vai bater no núcleo? Então tem duas possibilidades: vai até o núcleo e voltar ou passa reto. O passar reto seria o equivalente aos ângulos pequenos. É... Ok! Isso aqui é uma carga positiva [aponta para o desenho do núcleo].

$\mathbf{A}_{4}\left(\mathrm{I}_{5}\right)$ : Certo.

$\mathbf{P}_{4}$ : Essa aqui é uma partícula positiva [aponta para o desenho de uma partícula alfa].

$A_{4}\left(I_{5}\right)$ : Certo.

$\mathbf{P}_{4}$ : Não tem uma repulsão?

$\mathbf{A}_{4}\left(\mathbf{I}_{5}\right):$ Tem.

$\mathbf{A}_{3}\left(\mathbf{I}_{5}\right)$ : Então ela volta. 
$\mathbf{P}_{4}$ : Então ela volta. Então é uma coisa que vocês já sabem. Vamos comparar agora isso com o experimento. Ok?

$\mathbf{A}_{3}\left(\mathbf{I}_{5}\right)$ : Mas ela é só positiva, não tem negativa aí?

$\mathbf{P}_{4}$ : Partícula alfa é positiva e o núcleo é positivo.

$\mathbf{A}_{3}\left(\mathbf{I}_{5}\right)$ : Então todas voltam, nenhuma passa.

$\mathbf{P}_{4}$ : E o experimento, o que acontece com o experimento?

$\mathbf{A}_{2}\left(\mathbf{I}_{5}\right)$ : Muitas passam

$\mathbf{P}_{4}$ : Muitas passam, não é? Qual é a diferença que vocês têm disso aqui [aponta para o desenho] para o experimento? No experimento, no experimento... Olha! Isso aqui é uma folha de ouro [aponta para parte da simulação do experimento de Geiger-Marsden]. O que você tem aqui nessa folha de ouro? Você tem um átomo? Ou você tem vários átomos em uma folha de ouro.

$A_{3}\left(I_{5}\right)$ : Vários.

$\mathbf{P}_{4}$ : Vários, né. Então é como se você tivesse um núcleo aqui, outro núcleo aqui, e vários outros... [faz um desenho em uma folha de papel, representando núcleos atômicos lado a lado, como apresentado na Figura 29] Ok? Então você vai ter partícula alfa [desenha um ponto próximo ao desenho dos núcleos], imagina que isso é muito pequeno. Então se você jogar uma partícula alfa e ela veio aqui [desenha a trajetória entre dois núcleos]. O que vai acontecer com ela?

$\mathbf{A}_{1}\left(\mathbf{I}_{5}\right)$ : Passar pelo meio.

$\mathbf{P}_{4}$ : Passa pelo meio. Então, ainda assim com esse modelo atômico com um núcleo você consegue explicar o experimento de Rutherford [fala enquanto desenha a trajetória para outras duas partículas].

Segundo o que se nota no diálogo, o professor $\mathbf{P}_{4}$ identifica o raciocínio por detrás do questionamento da aluna e chama a atenção dos demais alunos do grupo. Por meio de explicações e utilizando desenhos (Figuras 28 e 29), o professor $\mathbf{P}_{4}$ se dedica a desconstruir o raciocínio incorreto.

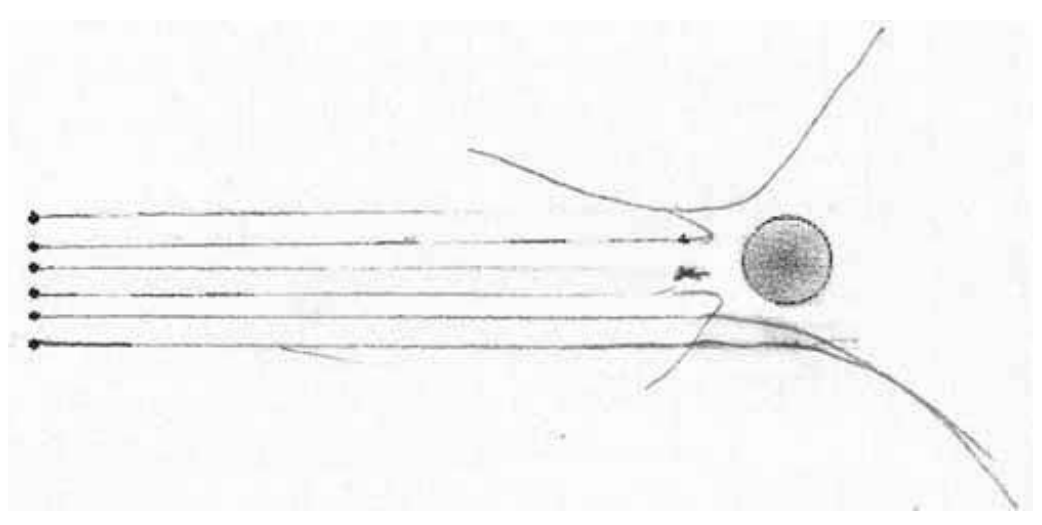

Figura 28. Desenho feito pela aluna $\boldsymbol{A}_{3}\left(I_{5}\right)$ para representar a interação entre as partículas alfa e o núcleo de um átomo. 
Figura 29. Desenho feito pelo professor $\mathbf{P}_{4}$, ao explicar os desvios com ângulos pequenos no experimento de Geiger-Marsden considerando o modelo atômico com um núcleo.

Nas situações $\underline{S}_{16}\left(\underline{1}_{2}\right), \underline{S}_{17}\left(\underline{1}_{4}\right)$ e $\underline{S}_{18}\left(\underline{1}_{5}\right)$ notamos a atuação de um raciocínio incorreto, o qual precisa ser desconstruído para um entendimento claro dos modelos atômicos envolvidos e suas relações com o experimento de Geiger-Marsden representado na simulação Rutherford Scattering. O raciocínio surge da observação de uma representação das trajetórias das partículas alfa próximas ao núcleo atômico, a qual é apresentada tanto no desenho da aluna $\boldsymbol{A}_{3}\left(\mathbf{I}_{5}\right)$ (Figura 28), como na simulação Up Close Rutherford Scattering. Como já comentado, tal raciocínio consiste em uma extrapolação de conclusões da observação em uma dimensão delimitada, da interação entre partículas alfa e o núcleo de um único átomo, para uma dimensão mais ampla envolvendo uma grande quantidade de átomos que fazem parte da lâmina de ouro do experimento de Geiger-Marsden. Como consequência, além do pensamento se estancar em conclusões de uma observação limitada, modelos já superados podem ser revalidados, como o ocorrido com o modelo de Thomson na situação $\left.\underline{S}_{1} \underline{6} \underline{1}_{2} \underline{1}\right)$.

Percebemos que o raciocínio envolvido se aproxima do obstáculo epistemológico do conhecimento unitário ${ }^{47}$ descrito por Bachelard. Ambos são obstáculos epistemológicos ligados a uma extrapolação da conclusão local para além dos seus limites. Ocorre pela falta de uma análise mais cuidadosa. Apesar dessa semelhança entre os obstáculos, há uma diferença fundamental que vale ser destacada: enquanto no conhecimento unitário de Bachelard há uma noção clara de unidade que leva a extrapolar conclusões e regras locais (o que explica uma parte

\footnotetext{
${ }^{47}$ Uma breve descrição do obstáculo do conhecimento unitário foi apresentada no tópico 5.1 da presente tese.
} 
de um todo, explica outra parte do todo), no obstáculo epistemológico que identificamos, o raciocínio surge aparentemente de forma espontânea durante a observação, sem uma noção explícita de unidade.

Como podemos perceber, principalmente na situação $\underline{S}_{18}\left(\underline{I}_{5}\right)$, a superação deste obstáculo passa por uma análise das diferenças entre os alvos destacados visualmente nas simulações: o núcleo atômico e a lâmina de ouro composta por muitos átomos (por consequência, por muitos núcleos com uma distância significativa entre si).

Outro ponto a se destacar, se refere ao papel da simulação Up Close Rutherford Scattering na emersão do obstáculo epistemológico identificado. Conforme já descrito, esta simulação levou a conclusões que foram utilizadas inadequadamente nas situações $\underline{S}_{16}\left(\underline{I}_{2}\right)$ e $\underline{S}_{17}\left(\underline{I}_{4}\right)$. No entanto, é notório que a situação de uso da simulação, ou a comparação desta com o experimento de Geiger-Marsden, é o que leva ao equívoco, e não a simulação em si.

Durante a elaboração do curso, a simulação foi pensada para ser utilizada em uma análise da interação das partículas alfa com o núcleo atômico, em um momento posterior no qual já se esperava que o átomo com um núcleo fosse identificado como mais adequado. Para este fim, a simulação se mostrou adequada, mas quando foi utilizada diretamente em uma interpretação do experimento de Geiger-Marsden, o que não era inicialmente esperado que ocorresse, a simulação se apresentou como inadequada. É compreensível que este uso inesperado tenha ocorrido, afinal, ainda que as simulações tenham sido utilizadas em tópicos diferentes, elas faziam parte de uma mesma atividade (III - Estrutura do átomo) e os tópicos eram discutidos em sequência.

Após a identificação deste obstáculo na $2^{\underline{a}}$ implementação do curso $\left(\mathbf{I}_{2}\right)$, 0 que ocorreu nas pré-análises que fizeram parte do momento de redesenho posterior à implementação $\left(\mathbf{D S}_{2}\right)$, os professores participantes permaneceram cientes da possibilidade de sua emersão, o que de certa forma ajudou em sua superação nas outras situações em que o obstáculo atuou. 


\section{3- Obstáculos didático-pedagógicos associados}

Apresentamos até aqui os obstáculos epistemológicos identificados nas seis implementações do curso nos contextos catalão e paulista. Entretanto, outros obstáculos também foram identificados, os quais possuíam uma natureza didáticopedagógica.

Conforme apresentamos no Capítulo 5, Brousseau (1997) define como obstáculos didáticos o resultado de eleições didáticas inadequadas presentes nos currículos, livros didáticos e no planejamento da aula ou durante uma situação de aula. Ao considerar que as eleições didáticas dos professores não são exclusivas de um único professor, mas se repetem na ação de diferentes professores, adotamos em nosso estudo o termo sugerido por Pietrocola (2008): obstáculosdidáticos pedagógicos. Como comentamos no Capítulo 5, situamos as eleições didáticas como parte da prática e da cultura docente e as entendemos como influenciadas pelo já instituído no âmbito dos saberes docentes.

Segundo o método de pesquisa empregado em nosso estudo e já apresentado, efetuamos uma análise de situações com o intuito de identificar obstáculos epistemológicos. Uma vez identificados, verificamos se ações dos professores tomadas no planejamento da aula (desenho do curso) ou no decorrer destas teriam influenciado, de alguma forma, na emersão dos obstáculos epistemológicos. Em outras palavras, buscamos verificar quais obstáculos didáticopedagógicos poderiam estar associados aos obstáculos epistemológicos identificados. Esta conexão entre obstáculos epistemológicos e didáticopedagógicos se justifica pela indissociabilidade entre o ensino e a aprendizagem, que se conectam numa relação dialética.

Diferentemente dos obstáculos epistemológicos, os obstáculos didáticopedagógicos foram organizados por relatos de casos. O menor volume de situações não gerou a necessidade de organização em categorias bem definidas. Identificamos três situações em que os obstáculos didático-pedagógicos se manifestaram: 1) o átomo de Thomson e a inadequação da palavra e da imagem; 2) o átomo de Thomson e a não desconstrução da metáfora; 3) o átomo nuclear e a ênfase na concentração de massa. Cada um destes casos é apresentado e discutido a seguir: 


\section{- Caso 1: o átomo de Thomson e a inadequação da palavra e da imagem}

Durante a implementação da versão piloto do curso, conforme o apresentado na situação $\left.\underline{S}_{5} \underline{1}_{1}\right)$, o aluno $\mathbf{A}_{1}\left(\mathbf{I}_{1}\right)$, ao fazer uma predição das trajetórias das partículas alfa que se descolavam em direção ao átomo de Thomson, indicava uma colisão entre as partículas e o átomo.

Durante o $1^{\text {o }}$ redesenho do curso (DS 1 ), ocorrido após a implementação piloto, este erro do aluno foi analisado. Conforme apresentado na situação $\left.\underline{S}_{5} \underline{1}_{1}\right), 0$ aluno se referia à palavra maciça presente no texto utilizado na atividade. Como esta palavra, de certa forma, remetia a uma ideia de impenetrabilidade, os professores participantes do redesenho (DS ${ }_{1}$ ) entenderam que o uso da palavra era o que poderia ter influenciado a predição do aluno envolvendo uma colisão, e assim, o trecho do texto foi modificado. O parágrafo que descrevia o átomo de Thomson, já traduzido do catalão para o português, era o seguinte:

Os átomos dos elementos consistem em um certo número de corpúsculos carregados negativamente, inclusos em uma esfera maciça de carga positiva uniforme (grifo nosso).

No redesenho do curso (DS 1 ), o parágrafo foi alterado conforme se segue, também já traduzido do catalão para o português:

Os átomos dos elementos consistem em um certo número de corpúsculos carregados negativamente, imersos em uma esfera com carga positiva e massa (grifo nosso).

Com esta mudança, era esperado que os alunos não representassem mais uma colisão entre as partículas e o átomo de Thomson, entretanto, na $2^{\underline{a}}$ implementação do curso $\left(\mathbf{I}_{2}\right)$, conforme registrado no caderno de campo, alguns alunos ainda representavam as trajetórias com colisões. Durante o redesenho (DS $_{2}$, considerou-se que a própria palavra massa poderia estar contribuindo para ideia de colisão. Com isso, durante o redesenho $\left(\mathbf{D S}_{2}\right)$ a descrição do átomo de Thomson foi novamente modificada, sendo inserida a descrição original presente no artigo de Thomson em que ele propôs o seu modelo atômico, na qual não referência à massa. A alteração resultou em algo semelhante ao apresentado no Texto 4, disponível na versão final do Material do Professor (Apêndice A).

Ainda no redesenho $\mathbf{D S}_{2}$, um dos professores comentou que alguns alunos teriam se referido a uma superfície do átomo de Thomson (visível na Figura 22) para justificar a colisão. Logo, a imagem utilizada (Figura 22), sobre a qual os alunos 
deveriam fazer o desenho das trajetórias, poderia também estar contribuindo para a emersão do obstáculo epistemológico. Como também havia a necessidade de reduzir o tempo dedicado à atividade, a imagem foi substituída pelo mapa de trajetórias (Figura 23), e a questão de predição foi reformulada, onde em lugar de solicitar aos alunos que se fizessem o desenho de trajetórias, era solicitado a eles que explicassem as trajetórias já apresentadas na nova figura.

No mesmo redesenho ( $\mathbf{D S}$ ), também se discutiu outro erro que envolvia uma imagem. Este erro, que estava relacionado com um obstáculo epistemológico, surgiu na situação $\underline{S}_{14}\left(\underline{I}_{2}\right)$ que apresentamos anteriormente. $O$ obstáculo epistemológico envolvia uma representação do átomo de Thomson (apresentada na Figura 26) presente no texto da atividade. Trata-se de uma imagem semelhante a muitas utilizadas com frequência quando se apresenta o átomo de Thomson. Conforme discutimos anteriormente, a imagem influenciou a leitura da simulação Rutherford Scattering.

Assim, além da mudança no trecho que descrevia o átomo de Thomson e da imagem envolvidas na questão que tratava da predição de como seria a interação entre as partículas alfa e o átomo de Thomson, também foi substituída a imagem que representava o átomo de Thomson. A nova imagem, que é apresentada na Figura 30, foi elaborada buscando se diferenciar visualmente do círculo presente na simulação Rutherford Scattering que representava o visor do experimento de GeigerMarsden e, ao mesmo tempo, utilizando-se uma alteração de cores gradual, se buscava remover a ideia de uma superfície impenetrável do átomo de Thomson.

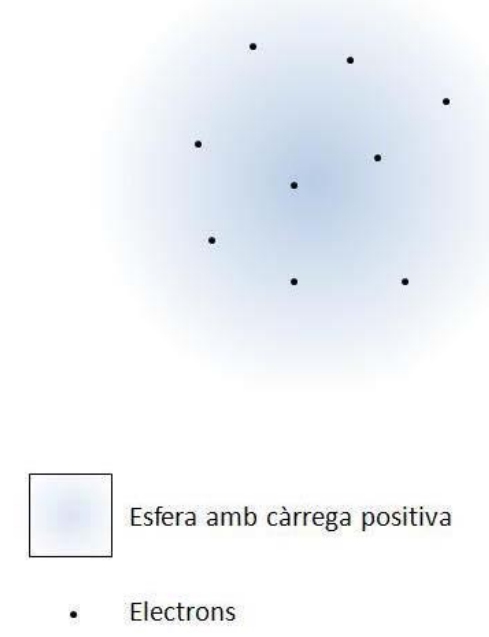

Figura 30. Representação do átomo de Thomson utilizada nas duas últimas implementações do curso na Catalunha. 
A imagem que passou a ser utilizada na apresentação do átomo de Thomson (Figura 30), a imagem representando o mapa de trajetórias das partículas alfa em sua interação com o átomo de Thomson (Figura 23) e a descrição do átomo de Thomson com base na descrição original de Thomson, foram utilizados até as últimas implementações do curso, o que pode ser verificado no Texto 4 disponível na versão final do Material do Professor (Apêndice A). Posteriormente, a única mudança em relação a essas imagens e ao Texto 4 se limitou à tradução, do catalão para o português, do texto e das legendas da imagem, no momento de preparação do material para as implementações em São Paulo.

De nossa análise, podemos concluir que obstáculos didático-pedagógicos relacionados à escolha de uma imagem (Figura 22) e à inserção de uma palavra (maciça e massa) atuaram facilitando a emersão de um obstáculo epistemológico da percepção direta, o qual envolvia a ideia de colisão mecânica. Outra imagem utilizada para a representação do átomo de Thomson (Figura 26), também pode ter contribuído para este obstáculo epistemológico, no entanto, foi mais nítida a contribuição da imagem em outro tipo de obstáculo epistemológico, que atuava na leitura de uma das simulações computacionais utilizadas, conforme apresentado na situação $\underline{\mathrm{S}}_{14}\left(\underline{I}_{2}\right)$. As imagens selecionadas se apresentaram como inadequadas, assim como o uso desnecessário das palavras massa e maciço na descrição do átomo de Thomson. Tais escolhas feitas na produção do material do curso que, portanto, fizeram parte do planejamento da situação de aula, se apresentaram como obstáculos didático-pedagógicos e, segundo constatamos, podem ter contribuído para a emersão de obstáculos epistemológicos.

- Caso 2: o átomo de Thomson e a não desconstrução da metáfora da nuvem

$\mathrm{Na}$ situação $\underline{\mathrm{S}}_{1 \underline{3}}\left(\underline{I}_{2} \underline{L}\right.$ que apresentamos e descrevemos anteriormente, percebemos o uso inapropriado dos elementos de uma metáfora que, a nosso ver, consistiu em um obstáculo epistemológico potencial. O professor $\mathbf{P}_{\mathbf{3}}$, ao comparar o átomo de Thomson com uma nuvem, no intuito de explicar que o átomo de Thomson poderia ser penetrado pelas partículas alfa, inicialmente não especifica que aspectos da comparação estavam sendo considerados. Segundo a definição de analogias e metáfora que adotamos em nossa pesquisa, a comparação do professor, uma vez 
que mantinha implícitos os elementos comparados, constitui-se como uma metáfora, e sua interpretação ficou a cargo do aluno $\mathbf{A}_{8}\left(\mathbf{I}_{2}\right)$, interlocutor do professor.

Como percebemos na situação $\underline{S}_{13}\left(\underline{I}_{2}\right)$, o aluno $\mathbf{A}_{8}\left(\mathbf{I}_{2}\right)$ acaba assumindo características de uma nuvem para entender a estrutura do átomo de Thomson, inclusive deduzindo que o átomo seria como um fluido, que poderia se deformar e ter em seu interior a formação de vórtices com a passagem das partículas.

Assim, podemos notar que a opção do professor na situação de aula por explicar a penetrabilidade no átomo de Thomson mediante o uso de uma metáfora, sem que houvesse imediatamente a desconstrução desta, se apresentou como um obstáculo didático-pedagógico que levou ao surgimento de ideias equivocadas. Tais ideias, se não fossem superadas, poderiam atuar de forma decisiva no processo de aprendizagem, integrando-se ao modelo mental do aluno correspondente ao modelo conceitual tratado.

Ao perceber o uso inapropriado da metáfora, o professor $\mathbf{P}_{\mathbf{3}}$ dedicou-se a desconstruí-la, e o que poderia atuar como um obstáculo epistemológico à aprendizagem foi superado se limitando ao que chamamos de obstáculo epistemológico potencial.

Desta situação, podemos concluir que a opção por utilizar metáforas, sem que em seguida seja apresentada uma explicação que busque explicitar os elementos comparados, constitui-se em um obstáculo didático-pedagógico, que como percebemos, pode levar a emersão de obstáculos epistemológicos.

\section{- Caso 3: o átomo nuclear e a ênfase na concentração de massa}

Conforme apresentado no subcapítulo 9.2, entre os obstáculos epistemológicos, muitos envolviam a ideia de colisão que é construída na experiência cotidiana a partir da observação da interação entre corpos macroscópicos. Em algumas das situações que apresentamos, a noção de concentração de massa, ainda que não estivesse incorreta, colaborava com a ideia de colisão. Na percepção ingênua dos alunos, corpos com massa permitem colisões, e se o átomo ou o seu núcleo possuem massa, as partículas alfa colidiriam nestes.

Considerando o obstáculo epistemológico que surge desta percepção ingênua, há de se considerar um uso cauteloso e esclarecedor do termo massa 
quando se trata de tópicos relacionados à estrutura atômica e outros que abordem o mundo microscópico. Por exemplo, deve-se evitar uma ênfase desnecessária sobre a questão da massa, algo que ocorreu e é apresentado na situação $\underline{S}_{1} \underline{\underline{g}}\left(\underline{I}_{5}\right)$ :

\section{Situação $\mathrm{S}_{19}\left(\underline{I}_{5}\right)$}

$\mathrm{Na} 1^{\text {a }}$ implementação ocorrida no contexto paulista, identificamos uma explicação do professor $\mathbf{P}_{4}$, durante uma discussão conjunta com a turma sobre os resultados do experimento de Geiger-Marsden e o átomo com um núcleo, em que a questão da massa era enfatizada:

$\mathbf{P}_{4}$ : E aí a questão é: tem um fato. Qual é o fato? Essa partícula alfa voltou com um ângulo grande. Não deveria voltar, voltou. É um fato, não posso negar isso. Como é que eu explico esse fato? Como é que ela vai voltar? E aí eu dei o exemplo da carreta e da bicicleta: se ela encontrar uma bicicleta lá dentro, ela bate na bicicleta e volta?

Muitos Alunos: Não.

$\mathbf{P}_{4}$ : Vai passar por cima. Então ela tem que encontrar o que lá?

$A_{2}\left(I_{5}\right)$ : Outra carreta.

[Trecho não compreensível]

$\mathbf{P}_{4}$ : Então, uma outra carreta? Se a partícula alfa é massiva, tem uma massa grande comparada com as outras entidades que a gente viu lá, o que ela encontrou lá dentro? Que massa ela encontrou lá dentro? Qual seria a massa disso? Teria que ser como?

$A_{3}\left(I_{5}\right)$ : Igual à dela.

$\mathbf{P}_{4}$ : Uma massa grande também, né? Exatamente. Ela deveria ter uma massa grande. Né? Sim?

Muitos Alunos: Sim.

$\mathbf{P}_{4}$ : Porque só ela encontrando uma coisa com uma massa grande que ela voltaria. Outra coisa: Porém, o problema é?

$A_{5}\left(I_{5}\right):$ que é essa massa grande?

$\mathbf{P}_{4}$ : Já até pensamos 0 que é essa massa grande. Agora, uma outra coisa que fica é que a maioria passou. A maioria passou. E poucas voltaram, e essas que voltaram encontraram alguma coisa com massa grande. $O$ que eu posso concluir disso? A maioria passa, a maioria passa, mas algumas poucas voltaram, e elas encontraram alguma coisa com massa grande. São poucas que voltaram. O que eu posso concluir? Já sei que tem alguma coisa com massa grande aqui. $\mathrm{O}$ que mais eu posso concluir se a maioria passa e poucas voltam? Eu sei que a massa é grande, dessa coisa que está lá dentro. $\mathrm{O}$ que mais que eu sei? A estrutura. Pensa na estrutura. $\mathrm{O}$ tamanho, essa coisa que está lá dentro, é grande?

$\mathbf{A}_{4}\left(\mathrm{I}_{5}\right): \dot{E}$. 
$\mathbf{P}_{4}$ : Pode ser uma coisa pequena. Uma coisa pequena que tem lá dentro. Porque a maioria das partículas passa. Mas quando a partícula alfa encontra essa coisa pequena, que é massiva. É pequena, mas é massiva, então ela volta. Então daí aquela ideia do Rutherford, de que a massa estaria concentrada toda quase no núcleo e o núcleo seria uma coisa pequena.

Como podemos perceber, o professor opta por explicar o núcleo do átomo a partir de uma ênfase na concentração de massa, que apesar de ser mais fácil associá-la com a analogia que ele vinha utilizando sobre a interação entre uma carreta e uma bicicleta, como veremos mais à diante, mostra-se inadequada.

O professor $\mathbf{P}_{5}$, que acompanhava a explicação do professor $\mathbf{P}_{4}$, talvez percebendo que a questão que era mais relevante na proposta de um átomo nuclear, a concentração de carga, não vinha sendo tratada, intervém:

$\mathbf{P}_{5}$ : E tem uma outra questão que vai ser colocada, que não somente, vocês têm que pensar não somente na questão da massa, mas também na questão da carga.

$\mathbf{P}_{4}$ : Da carga. Não é só o efeito da massa, é o efeito da carga também. Da carga positiva está toda concentrada lá. E aí a partícula alfa tem carga positiva, ela encontra uma coisa que tem carga positiva, que é massiva também, ela vai e... [gesticula representando uma trajetória da partícula se aproximando e após sendo desviada por repulsão].

$A_{8}\left(I_{5}\right)$ : A carga do elétron não surte efeito?

$\mathbf{P}_{4}$ : Muito pouco, o desvio devido as carga positivas... devido as cargas negativas, é muito pouco. Por que é pouco o desvio devido as cargas negativas?

$A_{5}\left(I_{5}\right)$ : Porque elas não se repelem.

$\mathbf{P}_{4}$ : Não, com relação à partícula alfa, a trajetória dela é pouco influenciada devido às cargas negativas? A gente viu anteriormente que... Como que é a massa do elétron comparada com a massa do próton? Ou melhor, o que é a massa do elétron comparada com a massa do átomo? A gente discutiu anteriormente, ela é muito pequena, né? A massa do elétron, comparado com a massa da partícula alfa, Rutherford já sabia, ela é muito pequena. Quase 3 mil vezes menor. Não, 2 mil vezes menor. Quase 2 mil vezes menor do que a massa da partícula alfa.

$\mathbf{P}_{5}$ : E é exatamente o que o professor $\mathbf{P}_{4}$ estava falando sobre a carreta e a bicicleta.

$\mathbf{P}_{4}$ : Então tem duas coisas jogando aí, as cargas, o sinal, e a massa. Então, embora o elétron tenha uma carga negativa, ela vai atrair a alfa, só que a alfa tem uma baita de uma massa, quando ela passa perto do elétron, ela sente a força dele, a força elétrica, mas ela desvia, mas desvia pouco. É aquilo que eu falei, é deslocar a carreta com a bicicleta. Logicamente, não vai desviar da trajetória. Tá? Essas duas coisas estão jogando aí, as cargas, o sinal das cargas, e a massa. 
A intervenção do professor $\mathbf{P}_{5}$ parece ter sido positiva, pois logo após, o professor $\mathbf{P}_{4}$ insere a questão da concentração da carga em seu discurso. No entanto, para responder o questionamento do aluno $\mathbf{A}_{8}\left(\mathbf{I}_{5}\right)$, se carga do elétron não atuaria sobre as partículas alfa, o professor retoma a explicação com ênfase na massa.

Após a discussão apresentada na situação $\underline{S}_{19}\left(1_{5}\right)$, os alunos se reuniram em grupo para chegar à proposta de um novo modelo de átomo, o qual segundo planejamento do curso se esperava que fosse semelhante ao átomo nuclear de Rutherford. Em seguida, os modelos propostos por cada grupo foram apresentados a toda turma. Todos os grupos apresentaram modelos com um núcleo, entretanto somente um indicou a concentração de carga elétrica positiva no núcleo, enquanto que os demais indicaram exclusivamente a concentração de massa no núcleo.

A seguir, a Figura 31 apresenta um desenho do átomo com um núcleo, feito por um dos alunos dos grupos que propuseram uma estrutura atômica indicando exclusivamente a concentração de massa. Já a Figura 32 apresenta o desenho de um dos alunos do grupo que propôs a estrutura atômica enfatizando a concentração de carga.

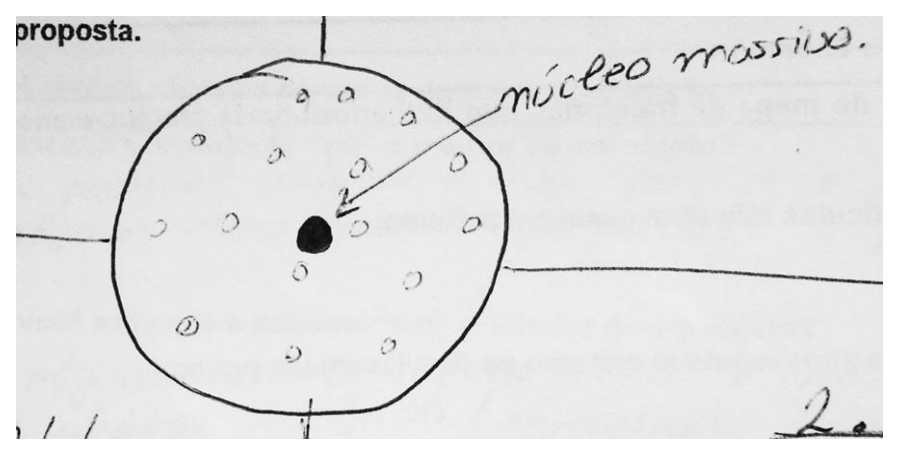

Figura 31. Desenho de um dos alunos, com a representação da estrutura atômica indicando a concentração de massa no núcleo.

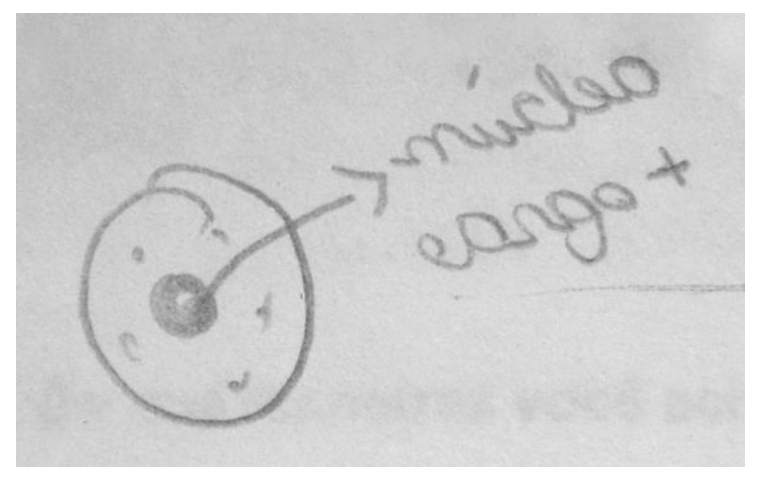

Figura 32. Desenho de um dos alunos, com a representação da estrutura atômica indicando a concentração de carga elétrica positiva no núcleo. 
Como podemos perceber, a ênfase na concentração de massa se apresentou como um obstáculo didático-pedagógico, como uma eleição inadequada do professor $\mathbf{P}_{4}$ no momento em que ele discutia com a turma os resultados do experimento de Geiger-Marsden e a ideia de um átomo nuclear. Além disso, conforme apresentamos nas situações $\underline{S}_{11} \underline{1}_{5} \underline{1}$ e $\underline{S}_{12}\left(\underline{I}_{5} \underline{2}\right)$ que ocorreram na mesma implementação $\left(\mathbf{I}_{5}\right)$, a explicação do professor $\mathbf{P}_{4}$ com uma ênfase na concentração de massa pode ter reforçado o obstáculo epistemológico relacionado à ideia de colisão mecânica.

As próprias propostas de modelo atômico apresentadas pela maioria dos alunos, como aquela representada na Figura 31, demonstram certa consolidação do obstáculo epistemológico: o átomo passa a ser visto como tendo um núcleo com massa, núcleo este que provoca desvios, e em que a questão da concentração de carga elétrica, por não ser destacada, parece não ser relevante ou nem mesmo ter sido notada pelos alunos. Assim, possivelmente para estes alunos, os desvios grandes poderiam ser vistos como consequência de colisões mecânicas que, conforme comentamos diversas vezes, não têm sentido no mundo microscópico. 


\section{0- CONSIDERAÇÕES FINAIS}

Após apresentar uma análise dos diferentes obstáculos epistemológicos e didático-pedagógicos identificados em situações de uso de simulações computacionais, os quais surgiram nos momentos de implementação de um curso sobre a estrutura da matéria, dedicamos este capítulo a apresentar algumas considerações finais.

- O ensino sobre a Estrutura da Matéria e o uso de simulações computacionais

Nossa pesquisa teve como pano de fundo um curso sobre a estrutura da matéria e os aceleradores de partículas, e assim, envolvia conceitos de Física Moderna e Contemporânea. Conforme nos dedicamos a apresentar no Capítulo 2, os conceitos de FMC se apresentam como contra intuitivos, de difícil percepção e tecnicamente relevantes.

Os fenômenos e entidades da FMC possuem características diferentes daquelas observáveis no cotidiano, não podem ser acessados diretamente pelos sentidos humanos, e se tornam reais mediante uma técnica. Assim, ensinar tais conceitos requer algum meio representativo, que não somente busque apresentar os fenômenos e entidades, mas também a técnica envolvida, ou seja, os experimentos onde estes se tornam reais. As simulações computacionais, como aquelas selecionadas para serem utilizadas no curso elaborado, atendem a estas necessidades. O curso desenhado, que possui como linha central a técnica empregada no estudo sobre a estrutura atômica e nos estudos envolvendo aceleradores de partículas, possui como principais atividades aquelas que se baseiam no uso das simulações.

A partir dos referenciais adotados e do observado ao longo da execução da pesquisa, acreditamos que a discussão conceitual mediante a técnica se apresenta como favorável ao ensino e aprendizagem de tópicos que tratam da realidade (tecnicamente construída) envolvida na Física do microcosmo, que integra a Física Moderna e Contemporânea. Além disso, acreditamos que o uso de simulações computacionais, que representem experimentos ou fenômenos de difícil acesso e 
em que parâmetros podem ser controlados, é algo que valoriza e ao mesmo tempo facilita a discussão conceitual mediante a técnica que nos referimos.

\section{- Um método de pesquisa baseado em um processo iterativo}

Em nossa pesquisa, conforme descrito, adotamos como parte do método empregado um processo iterativo que envolveu o desenho de um curso, sua implementação e momentos de redesenhos e novas implementações.

O processo iterativo, normalmente utilizado em pesquisas baseadas no desenho didático (Design-Based Research) e nos estudos envolvendo TeachingLearnig Sequences (TLS), se apresentou como útil para os interesses de pesquisa. Primeiro, por permitir um olhar amplo focado nas dimensões do ensino e da aprendizagem: uma vez que neste processo o pesquisador participa do desenho didático, ou seja, do planejamento das situações didáticas, torna-se mais claro ao pesquisador as escolhas didáticas que são feitas em função do modelo conceitual tratado e em função dos objetivos de ensino definidos. Com isso, o olhar sobre a aprendizagem não se restringe unicamente à perspectiva do aluno, mas também considera o papel do professor na aprendizagem. Este olhar duplo do ensino e aprendizagem tornou-se especialmente favorável ao estudo dos obstáculos epistemológicos e didático-pedagógicos envolvidos no uso de simulações computacionais. Segundo, por permitir um desenvolvimento de uma proposta didática para o ensino de um tópico específico, em que o desenvolvimento se baseia em um aperfeiçoamento gradual que considera os resultados de aprendizagem e as observações sobre o papel das ferramentas de ensino escolhidas: apesar de nossa pesquisa não se centrar no desenho didático, algo que é característico da linha Design-Based Research, o processo iterativo permitiu um aperfeiçoamento do curso sobre estrutura da matéria e aceleradores de partículas, culminando em uma versão final (apresentada no Apêndice A). Acreditamos que, com as devidas adequações, a versão final do curso pode ser utilizada com alunos da Educação Secundária em outros contextos de inovação curricular, os quais envolvam a inserção dos tópicos de Física Moderna e Contemporânea contemplados no curso.

A partir do que observamos em nossa pesquisa, vemos o método baseado em um processo iterativo de desenho didático e implementação como adequado não somente para pesquisas dentro da linha Design-Based Research ou, de forma mais específica, para aquelas que tratam das chamadas Teaching-Learnig Sequences. 
Entendemos que o processo iterativo é útil também para pesquisas que busquem analisar de forma mais integrada, o ensino e aprendizagem em situações de sala de aula.

- Obstáculos epistemológicos e obstáculos didático-pedagógicos identificados e o uso de simulações computacionais

Conforme afirmamos ao longo do texto, e que fica claro na descrição do processo de seleção e análise de dados utilizado na pesquisa, que é representado na Figura 9 apresentado ao final do Capítulo 7, o nosso foco de pesquisa esteve sobre os obstáculos epistemológicos que emergiam em situações de aula com alunos, nas quais eram utilizadas simulações computacionais que ocupavam um papel central em algumas das atividades.

Como se percebe ao longo do capítulo 9, muitos foram os obstáculos epistemológicos identificados. Entre estes, é possível notar que muitos são os que classificamos como obstáculos da percepção direta, que conforme definimos, são obstáculos relacionados às concepções espontâneas construídas em meio à experiência cotidiana, se integram ao senso comum, e baseiam-se na percepção direta amparada nos sentidos humanos. Isto nos leva a concluir que as ideias e conhecimentos que os alunos possuem de sua experiência cotidiana se tornam mais relevantes no estudo da Física Moderna e Contemporânea do que o próprio conhecimento de Física Clássica que é construído ao longo do percurso escolar, ainda que este tenha também a sua importância. Com isso, estamos dizendo que muitas das dificuldades presentes no processo de aprendizagem de tópicos de FMC podem estar associadas, não ao rompimento com a Física Clássica, mas sim ao rompimento com o conhecimento de senso comum.

De certa forma, é compreensível que assim seja. Os alunos da Educação Secundária, e as pessoas de maneira geral, possuem toda uma carga de experiências anteriores que se dão ao longo de suas vidas, experiências estas associadas ao senso comum e que vão interferir na compreensão do novo. Os alunos que se encontram na Educação Secundária possuem ainda um curto período de estudo da Física Clássica, mas o conjunto de conhecimentos da Física Clássica, que em grande parte acabam sendo delimitadas ao âmbito escolar, não são muitas vezes elencadas para interpretar o novo. 
Sendo assim, acreditamos que propostas de ensino de tópicos de FMC, mesmo aquelas que partem do conhecimento da Física Clássica como a envolvida na presente pesquisa, devem ser elaboradas de forma a considerar a atuação de ideias e concepções do conhecimento comum, e assim, prever possíveis obstáculos epistemológicos que possam atuar.

Conforme já comentamos, na pesquisa buscamos identificar a atuação de obstáculos epistemológicos nas situações de uso de simulações computacionais. O curso possuía nove tópicos distribuídos em cinco atividades, entre as quais, duas atividades envolviam o uso de três simulações computacionais. Todos os obstáculos epistemológicos identificados atuavam nas situações em que se utilizavam as simulações Rutherford Scattering e Up Close Rutterford Scattering.

Já nas situações de uso da $3^{\underline{a}}$ simulação, Scattering and Structure, não foi identificada a atuação de obstáculos epistemológicos. Vemos dois motivos para isso: primeiro, como se pode observar no Apêndice A, o uso desta simulação era optativo, algo que foi definido durante o desenho do curso com a intenção de permitir um melhor controle do tempo durante as implementações. A simulação só foi utilizada na última implementação no contexto catalão e nas implementações no contexto paulista, quando o desenho do curso já tinha alcançado uma estabilidade maior no que se refere ao sequenciamento das atividades e sua relação com o tempo previsto para o curso. Assim, foram poucos os momentos de uso da $3^{\underline{a}}$ simulação se comparado com o uso das demais simulações. Um segundo motivo, que nos parece mais relevante, se refere ao tipo do uso. A atividade envolvendo o uso da $3^{\text {a }}$ simulação (Scattering and Structure), que buscava comparar a técnica empregada no experimento analógico que era realizado no curso e a técnica empregada no experimento histórico de Geiger-Marsden, era utilizada como um reforço de aspectos que já vinham sendo discutidos extensivamente ao longo das atividades anteriores, e que eram tratados em duas questões que antecediam o uso da simulação. Assim, os possíveis obstáculos epistemológicos potenciais podem ter sido tratados e/ou superados antes do uso da $3^{\text {a }}$ simulação.

Em relação aos obstáculos didático-pedagógicos, estes assumiram um papel coadjuvante em nossa pesquisa, e foram identificados a partir dos obstáculos epistemológicos a eles associados. Conforme apresentamos, identificamos obstáculos didático-pedagógicos que refletiam escolhas didáticas inadequadas ou 
pouco adequadas realizadas no desenho das atividades ou na própria aula. Algumas escolhas didáticas permitiram a emersão de obstáculos epistemológicos, como no caso que descrevemos sobre o uso da metáfora da nuvem e a atribuição de propriedades inadequadas ao átomo de Thomson. Em outros casos, as escolhas didáticas reforçaram alguns obstáculos epistemológicos, como no caso que descrevemos em que um professor enfatizou a ideia de concentração de massa, a qual possivelmente era relacionada inadequadamente pelos alunos com uma ideia de colisão mecânica em uma dimensão subatômica.

\section{- O alcance da pesquisa}

A pesquisa envolveu dois contextos distintos, o catalão e o paulista. Porém, conforme já comentado, havia muitas similaridades entre os contextos. Os currículos oficiais da Comunidade Autônoma da Catalunha e do Estado de São Paulo possuem em comum alguns tópicos de Física Moderna e Contemporânea entre os conteúdos previstos para serem tratados na Educação Secundária (Bachillerato e Ensino Médio), como é o caso do tópico Estrutura da Matéria. Além disso, os alunos participantes da pesquisa, que em ambos os contextos possuíam idades entre 16 e 18 anos, cursavam o último ano da Educação Secundária em sua região e, assim, conforme o previsto nos currículos oficiais, já tinham anteriormente estudado os conceitos de Física Clássica. Outra semelhança entre os contextos era o fato dos professores participantes atuarem em turmas da Educação Secundária em suas respectivas regiões e, além disso, atuarem junto a projetos de pesquisa que eram realizados pelos grupos de pesquisa envolvidos neste estudo.

Conforme pode ser observado na discussão e análise dos resultados, muitos obstáculos epistemológicos semelhantes foram identificados em ambos os contextos, em especial, aqueles que definimos como obstáculos da percepção direta. Com base nesta constatação, acreditamos que os resultados e conclusões da presente pesquisa podem se estender a outros contextos que possuam características semelhantes. Ou seja, acreditamos que os mesmos obstáculos epistemológicos identificados em nosso estudo podem atuar em outras situações que envolvam o ensino de conceitos relacionados à Estrutura da Matéria para alunos que já tenham recebido um ensino formal de Física Clássica em um nível secundário, e que tenham uma idade semelhante a dos participantes da pesquisa. 
Além disso, mesmo nos casos em que os alunos não tenham passado por um ensino formal de Física Clássica, é possível que os obstáculos da percepção direta surjam, afinal, estes independem do conhecimento de Física Clássica que se possua.

\section{- Possibilidades de trabalho}

A partir das nossas reflexões ancoradas nas diferentes ideias que fizeram parte do nosso marco teórico, e a partir dos resultados obtidos em nosso estudo, somos instigados a novos questionamentos que podem ser alvo de trabalhos futuros.

No nosso estudo procuramos adotar uma perspectiva mais ampla ao tratar simultaneamente das dimensões do ensino e da aprendizagem, o que é representado na Figura 5 que apresentamos no subcapítulo 4.2. O nosso olhar repousou principalmente sobre os obstáculos epistemológicos, e assim, nos situamos mais próximos da dimensão da aprendizagem representada pela evolução dos modelos mentais e sua relação com o modelo conceitual. No entanto, ao mesmo tempo, ao considerarmos os obstáculos didático-pedagógicos, buscamos nos aproximar da dimensão do ensino.

Como em nossa pesquisa os obstáculos didático-pedagógicos foram buscados e descritos em função dos obstáculos epistemológicos a eles associados, algo que pode ser investigado em trabalhos futuros são os possíveis obstáculos didático-pedagógicos que não necessariamente levam ao surgimento ou reforço de obstáculos epistemológicos, mas que ainda assim impliquem em dificuldades didáticas, como aquelas relacionadas à organização do conteúdo e das atividades, ao fluxo do ensino, entre outros.

Considerando ainda a perspectiva mais abrangente relacionada aos obstáculos didático-pedagógicos, outra questão que pode ser alvo de um estudo mais específico se refere a como aspectos próprios da transposição didática e/ou pertencentes ao saber docente remetem a estes obstáculos em situações de ensinoaprendizagem do tema Estrutura da Matéria.

Por fim, em relação aos obstáculos epistemológicos, novos estudos podem ser realizados com o intuito de identificar aqueles que atuem no processo de ensinoaprendizagem de outros tópicos de Física Moderna e Contemporânea, que 
igualmente ao tópico Estrutura da Matéria envolvido em nosso estudo, abordem conceitos e ideias contra intuitivas, relacionados a fenômenos e entidades não diretamente perceptíveis e que se tornam realidade mediante a técnica, isto é, mediante a experimentação. 


\section{REFERÊNCIAS}

AMBROSIS, A.; LEVRINI, O. Insernare Renaività ristretta a scuola: esigenze degli insegnanti e proposte innovative. Giornale di Física, Bologna, v. 48, n. 4, p. 255-276, 2007.

ANDRADE, B. L.; ZYLBERSZTANJ, A.; FERRARI, N. As analogias e metáforas no ensino de ciências à luz da epistemologia de Gaston Bachelard. Ensaio - Pesquisas em Educação em Ciências, Belo Horizonte, v. 2, n. 2, p. 1-11, 2002.

ARRUDA, S. de M.; SCARMINO, J.; VILLANI, A.; MARIANI, M. C. A General Strategy to Teaching and Learning Modern Physics. 1997. In: IV International HPST Group North \& South America Regional Conference, 1997, Calgary. Proceedings IV International HPSTG North \& South America Regional Conference. Calgary Canada, 1997. v. CD-ROM. p. 64-7.

ARTIGUE, M. Ingéniérie didactique. Recherches en didactique des Mathématiques. Grenoble, v. 9, n. 3, p.281-308, 1988.

AUBRECHT, G. J. Redesigning courses and textbooks for the twenty-first century. American Journal of Physics, v. 57, n. 4, p. 352-359, 1989.

AVCI, U.; ASKAR, P. The Comparison of the Opinions of the University Students on the Usage of Blog and Wiki for Their Courses. Educational Technology \& Society, v. 15, n. 2, p. 194-205, 2012.

BACHELARD, G. Le rationalism appliqué. Paris: PUF 1975, 5 ed. Tradução de Nathanael C. Caixeiro. O racionalismo aplicado. Rio de Janeiro: Zahar Editores, 1977.

BACHELARD, G. La philosophie du non: essai d'une philosophie du nouvel esprit scientifique. Paris: PUF, 1940. Tradução de Joaquim José Moura Ramos. Bachelard, Gaston,1884-1962: A filosofia do não, O novo espírito científico, a poética do espaço. Coleção Os pensadores. São Paulo: Abril Cultural, 1978.

BACHELARD, G. La formation de l'ésprit scientifique: contribution a une psychanalyse de la connaissance. Paris: Libraine Philosophique J. Vrin, 1938. 
Tradução de Estela dos Santos Abreu. A formação do espírito científico: contribuição para uma psicanálise do conhecimento. Rio de Janeiro: Contraponto, 1996.

BARBOSA, E.; BULCÃO, M. Bachelard: pedagogia da razão, pedagogia da imaginação. Petrópolis: Vozes, 2004, 102 p.

BAROJAS, J. Cooperative networks in physics education. New York: American, 1998.

BAWDEN, D. Information and digital literacies: a review of concepts. Journal of Documentation, Londres, v. 57, n. 2, p. 218-259, 2001.

BEICHNER, R. J. The effect of simultaneous motion presentation and graph generation in a kinematics lab. Journal of Research in Science Teaching, Nova York, v. 27, n.8, p 803-815, 1990.

BELEI, R. A.; GIMENIZ-PASCHOAL, S. R.; NASCIMENTO, E. N.; MATSUMOTO, P. H. V. R. O uso de entrevista, observação e videogravação em pesquisa qualitativa, Cadernos de Educação (FaE/PPGE/UFPel), Pelotas, n. 36, p. 187-199, 2008.

BETZ, M.; LIMA, I.; MUSSATTO, G. Dualidade onda-partícula: um objeto de aprendizagem baseado no interferômetro de Mach-Zehnder. Revista Brasileira de Ensino de Física, São Paulo, v. 31, n. 3, p. 35011-35018, 2009.

BINGIMLAS, K. A. Barriers to the successful integration of ICT in teaching and learning environments: A review of the literature. Eurasia Journal of Mathematics, Science \& Technology Education, v. 5, n. 3, p. 235-245, 2009.

BLACK, M. Models and metaphors: Studies in language and philosophy. Ithaca, NY: Cornell University Press. 1962.

BOECHAT, V. A. P. Ambientes Virtuais para o Ensino de Física. 2006. 152 f. Dissertação (Mestrado em Ciências Naturais), Universidade Estadual do Norte Fluminense, Campos dos Goytacazes.

BORGES, T. Um estudo de modelos mentais. Investigações em Ensino de Ciências. Porto Alegre, v. 2, n. 3, p. 207-226, 1997. 
BRASIL. Ministério da Educação, Pronlnfo - Apresentação. 2013. Disponível em: <http://portal.mec.gov.br/index.php?ltemid=462>. Acesso em: 10 jun. 2013.

BROCKINGTON, G.; PIETROCOLA, M. Serão as regras da Transposição Didática aplicáveis aos conceitos de Física Moderna?. Investigações em Ensino de Ciências, Porto Alegre, v. 10, n. 3, p. 1-17, 2005.

BROCKINGTON, G.; PIETROCOLA, M. Curso de dualidade OndaPartícula para o Ensino Médio, 2007.

BROCKINGTON, G.; GURGEL; I.; BEIG, F. PIETROCOLA, M. Curso de Relatividade para o Ensino Médio, 2007.

BROCKINGTON, G.; GURGEL; I.; SIQUEIRA; M. FORATO, T. C. M.; AZEVEDO, M. C. P. S.; UETA, N.; PIETROCOLA, M. A project to update the physics curriculum in the secondary school in brazil. In: onono, 2008, Anastosia. GIREP, ANASTOSIA: GIREP, 2008.

BROCKINGTON, G.; GURGEL, I.; PIETROCOLA, M. Teaching of modern physics in secondary education: a course in special relativity. In: International Conference on Physics Education, 2007, Marrakech. International Conference on Physics Education. Marrakech: ICPE, 2007.

BROCKINGTON, G.; PIETROCOLA, M. Physique Quantique au Lycée: la structuration et l'évaluation d'un cours à travers la Théorie de la Transposition Didactique. In: Les 29es Journées Internationales sur la Communication, l'éducation et la culture scientifiques, techniques et industrielles, 2008, Chamonix. Les 29es Journées Internationales sur la Communication, l'éducation et la culture scientifiques, techniques et industrielles, Chamonix: JIES, 2008.

BROCKINGTON, G.; SIQUEIRA, M.; PIETROCOLA, M. The use of activities for the teaching of modern physics in the secondary school. In: International Conference on Physics Education, 2007, Marrakech. International Conference on Physics Education. Marrakech: ICPE, 2007.

BROUSSEAU, G. Les obstacles épistémologique et les problèmes en Mathématiques. Recherches en Didactique des Mathématiques. Grenoble, v. 4, n. 2, p.165-198, 1983. 
BROUSSEAU, G. Fondaments et méthodes de la didactique des Mathématiques. Recherches en Didactique de Mathématiques, Grenoble, v. 7, n. 2, p. 33-115, 1986.

BROUSSEAU, G. La théorie des situations didactiques, Disponível em $<$ https://math.unipa.it/ grim/brousseau_montreal_03.pdf>. Acesso em: 26 jun. 2013, 1997.

BROUSSEAU, G. Iniciacíon al estudio de la teoría de las situaciones didácticas. Buenos Aires: Libros del Zorzal, 2007, 128 p. Tradução de Camila Bogéa. Introdução ao estudo da teoria das situações didáticas: conteúdos e métodos de ensino. São Paulo: Ática, 2008.

BULCÃO, M. O racionalismo da ciência contemporânea: Introdução ao Pensamento de Gaston Bachelard. Aparecida: Idéias \& Letras, 2009, 232 p.

CAMILLONI, A. R. W. Los obstáculos epistemológicos en la enseñanza. Barcelona: Gedisa, 1997, 223 p.

CASTELÃO-LAWLESS, T. Phenomenotechnique in Historical Perspective: Its Origins and Implications for Philosophy of Science, Philosophy of Science, Chicago, v. 62, n. 1, p. 44-59, 1995.

CATALUNYA, Departamento de Educación - Decreto 142/2008, de 15 de julio, por el que se establece la ordenación de las enseñanzas del bachillerato. Diari Oficial de la Generalitat de Catalunya: Núm. 5183 - 29.7.2008, jul 2008. Disponível em: <http://www.gencat.cat/eadop/imagenes/5183/08190087.pdf>. Acesso em: 15 abr. 2012.

CHENG, C. K.; PARÉ, D. E.; COLLIMORE, L.; JOORDENS, S., Assessing the effectiveness of a voluntary online discussion forum on improving students' course performance, Computers \& Education, n. 56, p. 253-261. 2011.

CHEVALLARD, Y. La transposition didactique: du savoir savant au savoir enseigné. Paris: La Pensée Sauvage, 1985. Tradução de Claudia Gilman. La transposición didáctica: del saber sabio al saber enseñado. Buenos Aires: Aique, 2009, 196p. 
CHOY, S.; NG, C., Implementing wiki software for supplementing online learning, Australasian Journal of Educational Technology, v. 23, n. 2, p. 209-226. 2007.

CHURCHILL, D., Towards a useful classification of learning objects, Educational Technology Research and Development, v. 55, n. 5, p. 479-497, 2007.

CLEMENT, J. J. Model based learning as a key research area for science education. International Journal of Science Education, Londres, v. 22, n. 9, p. 1041-1053, 2000.

COLL, R. K.; FRANCE, B.; TAYLOR, I. The role of models/and analogies in science education: implications from research, International Journal of Science Education, Londres, v. 27, n. 2, p. 183-198, 2005.

COSTA, I.; SANTOS, M. A física moderna e contemporânea na sala de aula da escola média. 1999. In: Simpósio Nacional de Ensino de Física, 13., 1999, Brasília. Anais eletrônicos... Brasília: SBF.

COUSO, D. Las secuencias didácticas en la enseñanza y el aprendizaje de las ciencias: modelos para su diseño y validación. In: CAAMAÑO, A., Didáctica de la física y la química, Barcelona: GRAÓ. p. 57-84, 2011.

COUSO, D.; HERNANDÉZ, M. I. PINTÓ, R.; GUITART, F.; COBETA, O. P. Unidades didácticas y proyectos de calidad en la enseñanza de la Física. In: CAAMAÑO, A., Física y química: Investigación, innovación y buenas prácticas Enseñanza de las Ciências, Barcelona: GRAÓ. p. 31-58, 2011.

COUSO, D.; PINTÓ, R. Análisis del contenido del discurso cooperativo de los profesores de ciencias en contextos de innovación didáctica. Enseñanza de las Ciências, Barcelona, v. 27, n.1, p. 5-18, 2009.

COX, M. J.; WEBB, M. E. ICT and Pedagogy: A Review of the Research Literature. Coventry and London: British Educational Communications and Technology Agency/Department for Education and Skills. 2004.

CUPPARI, A.; RINAUDO, G.; ROBUTTI, O.; VIOLINO, P., Gradual introduction of some aspects of quantum mechanics in a high school curriculum. Physics Education, Bristol, v. 32, n.5, p. 302-308, 1997. 
CUSTÓDIO, A.; ZANETIC, J. É possível levar a física quântica para o ensino médio?. Caderno Catarinense de Ensino de Física. Florianópolis, v. 16, n. 1, p. 734, 1999.

DAS, A.; FERBEL, T. Introduction to nuclear and particle physics. 2nd ed. Singapura: World Scientific Publishing, 2003, 399 p.

DELIZOICOV D. Conhecimento, Tensões e Transições. 1991. 131 f. Tese (Doutorado em Educação), Universidade de São Paulo, São Paulo.

DESIGN-BASED RESEARCH COLLECTIVE. Design-based research: An emerging paradigm for educational inquiry. Educational Researcher, v. 32, n. 1, 58, 2003.

DUARTE, M. C. Analogias na Educação em Ciências: contributos e desafios. Investigações em Ensino de Ciências, Porto Alegre, v. 10, n. 1, p. 7-29, 2005.

DUIT, R. On the role of analogies and metaphors in learning science. Science Education, v. 75, n. 6, p. 649-672, 1991.

DUIT, R.; ROTH, W.; KOMOREK, M.; WILBERS, J. Fostering conceptual change by analogies - between Scylla and Charybdis. Learning and Instruction, $v$. 11, n. 4-5, p. 283-303, 2001.

DUIT, R.; GLYNN, S. Mental modelling. In: Welford, G.; Osborne, J.; Scott, P. (Ed.) Research in Science Education in Europe. Londres: The Falmer Press, 1996, p. 166-176.

FERRY, A. S. Analogias e contra-analogias: uma estratégia didática auxiliar para o ensino de modelos atômicos. 2008, 261 f., Dissertação (Mestrado em Educação Tecnológica) Centro Federal de Educação Tecnológica de Minas Gerais, Belo Horizonte, 2008.

FISCHER, H.; LICHTFELDT, M. Learning Quantum Mechanics. Research in Physics Learning, Theoretical Issues and Empirical Studies. Proceedings of the International Workshop, Bremen, 1991.

FISCHER, H.; LICHTFELDT, M. Modern Physics and Students' Conceptions, Journal of Science Education, London, v. 14, n. 2, p. 181-190, 1992. 
FOGAÇA, M. Blog no ensino de ciências: uma ferramenta cultural influente na formação de identidades juvenis. 2011, 350 f. Teses (Doutorado em Educação) - Faculdade de Educação, Universidade de São Paulo, São Paulo, 2011.

FRIESE, S. ATLAS.ti 6 Tour Rápido, Berlim, 2011. Disponível em: <http://www.atlasti.com/uploads/media/QuickTour_a6_pt.pdf> Acesso em: 26 set. 2013.

GARDNER, H. , Inteligências Múltiplas: A teoria na prática. Porto Alegre: Artes Médicas, 1995, 257 p.

GERSTER, R.; ZIMMERMANN, S. Information and Communication Technologies (ICTs) and Poverty Reduction in Sub Saharan Africa: A Learning Study (Synthesis), Gerster Consulting, Richterswil, Out. 2003.

GIL, D. P.; SOLBES, J. The Introduction of Modern Physics: overcoming a deformed vision of science. International Journal of Science Education, Londres, v. 15, n. 3, p. 255-260, 1993.

GIL, D. P., SENENT, F., SOLBES, J. La introducción a la física moderna: un ejemplo paradigmático de cambio conceptual. Enseñanza de las Ciencias, Barcelona, p. 209-210, 1987, Número especial.

GIL, D. P., SENENT, F.D. \& SOLBES, J. Física Moderna en la enseñanza secundaria: una propuesta fundamentada y unos resultados, Revista Española de Física, Madrid, v. 3, n. 1, p. 53-58, 1989.

GILBERT, S. Models and modelling: routes to more authentic science education, International Journal of Science and Mathematics Education, Taipei, n. 2, p. 115-130, 2004.

GOBERT, J. D.; CLEMENT, J. J. Student-generated diagrams versus student-generated summaries on conceptual understanding of causal and dynamic knowledge in plate tectonics. Journal of Research in Science Teaching, Pensacola, v. 36, n. 1, p. 39-53, 1999.

GOMES, H. J. P.; OLIVEIRA, O. B. Obstáculos epistemológicos no ensino de ciências: um estudo sobre as influencias nas concepções de átomo. Ciência e Cognição. Rio de Janeiro, v.12, p.96-109, 2007. 
GONZÁLEZ, B. M. G. El modelo analógico como recurso didáctico en ciencias experimentales. Revista Iberoamericana de Educación, n. 37/2, p.1-15, 2005.

GRECA, I. M.; MOREIRA, M. A. Modelos mentales, modelos conceptuales y modelización. Caderno Catarinense de Ensino de Física. Florianópolis, v. 15, n. 2, p. 107-120, 1998.

GRECA, I. M.; MOREIRA, M. A. Mental models, conceptual models, and modeling. International Journal of Science Education, Londres, v. 22, n.1, p. 1$11,2000$.

HARRISON, A. Y TREAGUST, D., A typology of school science models, International Journal of Science Education, Londres, v. 22, n. 9, p. 1011-1026, 2000.

HENNESSY, S.; DEANEY, R.; RUTHVEN, K. Research Report 03/1 Pedagogic Strategies for Using ICT to Support Subject Teaching and Learning: An Analysis Across 15 Case Studies. Faculty of Education, University of Cambridge, 2003.

IGLIORI, S. B. C., A noção de "obstáculo epistemológico" e a educação matemática, In: MACHADO, S. D. A. (Org.), Educação Matemática: uma (nova) introdução, São Paulo: EDUC, 2008, p. 113-142.

KALMUS, P. Particle physics at A-level-the universities' viewpoint. Physics Education, Bristol, v. 27, n. 2, p. 62-64, 1992.

KCVS. Rutherford Scattering. 2010a. Disponível em: <http://www.kcvs.ca/site/projects/physics_files/rutherford/historical_scattering2.swf>. Acesso em: 20 mar. 2012.

KCVS. Up Close Rutherford Scattering. 2010b. Disponível em: $<$ http://www.kcvs.ca/site/projects/physics_files/rutherford/scattering2.swf>. Acesso em: 20 mar. 2012.

KCVS. Scattering and Structure. 2010c. Disponível em: $<$ http://www.kcvs.ca/site/projects/physics_files/rutherford/other_nuclei.swf>. Acesso em: 20 mar. 2012. 
KCVS. KCVS - Who Are We?. 2011. Disponível em: <http://www.kcvs.ca/site/who.html >. Acesso em: 20 mar. 2012.

KHAN, S. Model-based inquiries in chemistry. Science Education, v. 91, n. 6, p. 877-905, 2007.

KLEER, A. A.; THIELO, M. R.; SANTOS, A. C. K. A física utilizada na investigação de acidentes de trânsito. Caderno Catarinense de Ensino de Física, Florianópolis, v. 14, n. 2, p. 160-169, 1997.

KNECHT, W. (ed). New trends in physics teaching (1965-1966), v.1, Paris: UNESCO, 1968.

LIJNSE, P. "Developmental research" as a way to an empirically based "Didactical structure" of science. Science Education, v. 79, n. 2, p. 189-199, 1995.

LOBATO, T.; GRECA, I. M. Análise da inserção de conteúdos de teoria quântica nos currículos de física do ensino médio. Ciência \& Educação, v. 11, n. 1, 119-132, 2005.

LOPES, A. R. C. Livros didáticos: Obstáculos ao aprendizado das ciências físicas. 1990, 289 f., Dissertação (Mestrado em Educação) - Instituto de Estudos Avançados, Fundação Getúlio Vargas, Rio de Janeiro, 1990.

LOPES, A. R. C. Livros Didáticos: Obstáculos ao Aprendizado da Ciência Química. Química Nova, São Paulo, v. 15, n. 3, p. 254-261, 1992.

LOPES, A. R. C. Livros Didáticos: Obstáculos Verbais e Substancialistas* ao Aprendizado da Ciência Química. Revista Brasileira de Estudos Pedagógicos, Brasília, v. 74, n. 177, p. 309-334, 1993a.

LOPES, A. R. C. Contribuições de Gaston Bachelard ao ensino de Ciências. Enseñanza de las Ciencias, Barcelona, v. 11, n. 3, p. 324-330, 1993 b.

LOPES, A. R. C. A concepção de fenômeno no ensino de química brasileiro através dos livros didáticos. Química Nova, São Paulo, v. 17, n. 4, p. 338-341, 1994.

LOPES, A. R. C. Bachelard: o filósofo da desilusão. Caderno Catarinense do Ensino de Física, Florianópolis, v. 13, n. 3, p. 248-273, 1996.

MARX, G. (ed). Atoms in the school, proceedings of the first and second Danube Seminar, Budapest: Roland Eötvös Physical Society, 1975. 
MÉHEUT, M.; PSILLOS, D. Teaching-Learning Sequences: aims and tools for science education research. International Journal of Science Education, Londres, v. 26, n. 5, p. 635-652, 2004.

MELO, A. C. S. Contribuições da epistemología histórica de Bachelard no estudo da evolução dos conceitos da óptica. 2005, 199 f. Dissertação (Mestrado em Educação Científica e Tecnológica) - Universidade Federal de Santa Catarina, Florianópolis, 2005.

MENDONZA, L. E. V. La noción de obstáculo epistemológico en Gastón Bachelard. Espéculo - Revista de Estudos Literários, Madri, n. 38, 2008.

MONTEIRO, M. A; NARDI, R.; BASTOS FILHO, J. B. Dificuldades dos professores em introduzir a física moderna no ensino médio: a necessidade de superação da racionalidade técnica nos processos formativos. In: NARDI, R (Org.). Ensino de ciências e matemática, I: temas sobre a formação de professores. Porto Alegre: São Paulo: Editora UNESP, 2009, p. 145-159.

MORTIMER, E. F. Construtivismo, Mudança Conceitual e Ensino de Ciências: Para Onde Vamos?. Investigações em Ensino de Ciências, Porto Alegre v. 1, n. 1, p. 20-39, 1996.

NETO, R. A. de; FREIRE Jr. O.; ROCHA, J. F. M. Revelando o caráter determinístico da Mecânica Quântica - uma ponte para o ensino de física moderna no segundo grau. Ideação, Feira de Santana, v. 3, n.1, p. 51-68, 1999.

NICOLAU JUNIOR, J. L.; BROCKINGTON, G.; SASSERON, L. H. Formação contínua de professores para abordagem de tópicos de Relatividade no Ensino Médio: saberes docentes dos implementadores. Experiências em Ensino de Ciências. Cuiabá, v. 6, n. 2, p. 96-106, 2011.

OCDE. Learning to Change: ICT in Schools, Paris, 2001.

OLIVA, J. M.; ARAGÓN, M. M.; MATEO, J.; BONAT, M. Una propuesta didáctica basada en la investigación para el uso de analogías en la enseñanza de las ciencias. Enseñanza de las ciencias, Barcelona, v. 19, n. 3, 453-470, 2001.

OGBORN, J., Introducing relativity: less may be more. Physics Education, Bristol, v. 40, n. 3, p. 213-222, 2005. 
OSBORNE, J.; HENNESSY, S. Literature Review in Science Education and the Role of ICT: Promise, Problems and Future Directions. Futurelab Series, Report 6, 2003.

OSTERMANN, F.; CAVALCANTI, C. J. H. Física moderna e contemporânea no ensino médio: elaboração de material didático, em forma de pôster, sobre partículas elementares e interações fundamentais. Caderno Catarinense de Ensino de Física, Florianópolis, v. 16, n. 3, p. 267-286, 1999.

OSTERMANN, F.; MOREIRA, M. A. Física contemporánea en la escuela secundaria: una experiencia en el aula involucrando formación de profesores. Enseñanza de las Ciências, Barcelona, v. 18, n. 3, p. 391-404, 2000.

PIAGET, J. Intellectual Evolution from Adolescence to Adulthood. Human Develop, v. 15, p. 1-12, 1972.

PIETROCOLA, M. Modern Physics In Brazilian Secondary Schools. In: International Conference on Physics Education, 2005, Nova Delhi. International Conference on Physics Education. Nova Delhi: ICPE, 2005.

PIETROCOLA, M. A Transposição da Física Moderna e Contemporânea para o Ensino Médio: superando obstáculos epistemológicos e didáticopedagógicos. In: BORGES, R. M. R.; ROCHA FILHO, J. B.; BASSO, N. R. S. (Org.). Avaliação e Interatividade na Educação Básica em Ciências e Matemática. Porto Alegre: EDUC, 2008, p. 159-180.

PIETROCOLA, M.; BROCKINTON, G. Recursos computacionais disponíveis na internet para o ensino de Física moderna e contemporânea. In: Encontro de Pesquisa em Ensino de Ciências, 3., 2003, Bauru. Atas do 3a Encontro de Pesquisa em Ensino de Ciências. Bauru: ABRAPEC, 2003.

PIETROCOLA, M.; GURGEL, I.; NICOLAU, J.; WATANABE, G.; TAGIKU; A.; SANTOS, I.; VICENTINI, H.; OLIVEIRA, L.; BEIG, F.; FAGUNDES, M. B.; HENRIQUE, A. B. Development of a TLS on the relativity of time and the Twin Paradox: Analysis of its Structural Elements. In: The World Conference on Physics Education, 2012, Istambul. The World Conference on Physics Education. Istambul: WCPE, 2012. 
PINTÓ, R. Introducing Curriculum Innovations in Science: Identifying Teachers' Transformations and the Design of Related Teacher Education. Science Education, v. 89, n.1, p. 1-12, 2005.

PINTÓ, R.; COUSO, D.; GUTIERREZ, R. Using Research on Teachers' Transformations of Innovations to Inform Teacher Education: The Case of Energy Degradation. Science Education, v. 89, n.1, p. 38-55, 2005.

PINTÓ, R.; COUSO, D.; HERNÁNDEZ, M. I. An inquiry-oriented approach for making the best use of ICT in the classroom. eLearning Papers, n.20, p. 1-14, 2010.

PONTE, J. P. Tecnologias de informação e comunicação na formação de professores: Que desafios?. Revista Iberoamericana de Educación, Madri, n. 24, p. $62-90,2000$.

PRATA, C. L.; NASCIMENTO, A. C. A. A.; PIETROCOLA, M. Políticas para Fomento de Produção e Uso de Objetos de Aprendizagem. In: PRATA, C. L.; NASCIMENTO, A. C. A. A. (Ed.). Objetos de Aprendizagem: uma Proposta de Recursos Pedagógicos. 1 ed. Brasília: Ministério da Educação, 2007, p. 107-122.

RAVIOLO, A., Modelos, analogías y metáforas en la enseñanza de la química. Educación Química, Cidade do México, v. 20, n.1, p. 55-60, 2009.

RHEINBERGER, H., Gaston Bachelard and the Notion of "Phenomenotechnique". Perspectives on Science, Nova York, v. 13, n.3, p. 313328, 2005.

ROTH, W. M., Affordances of computers in teachers students interactions: the case of Interactive Physics TM. Journal of Research in Science Teaching, Nova York, v. 32, n.4, p. 329-347, 1995.

SANTOS, A., Modelamento computacional através do sistema de modelamento celular (CMS): alguns aspectos. Caderno Catarinense de Ensino de Física, Florianópolis, v. 7, n. 1, p. 31-39, 1990.

SÃO PAULO. Proposta Curricular do estado de São Paulo - Física - Ensino Médio. São Paulo, $2008 . \quad$ Disponível em: $<$ http://www.rededosaber.sp.gov.br/portais/Portals/18/arquivos/Prop_FIS_COMP_red _md_20_03.pdf $>$. Acesso em: 14 out. 2010. 
SCHWARZ, C. V.; WHITE, B. Y. Metamodeling knowledge: Developing students' understanding of scientific modeling. Cognition and Instruction, v. 23, n. 2, p. 165-205, 2005.

SELWYN, N. O uso das TIC na educação e a promoção de inclusão social: Uma perspectiva crítica do Reino Unido. Educação \& Sociedade, Campinas, v. 19, n. 104 , p. $815-850,2008$.

SESSLER, A.; WILSON, E. (2007), Engines of discovery: A Century of Particle Accelerators. Singapura: World Scientific Publishing, 2007, 194 p.

SILVEIRA, H. E.; DIAS, S. S.; LEITE, V. M. Obstáculos epistemológicos em livros didáticos: um estudo das imagens de átomos. Candombá - Revista Virtual, Salvador, v.2, n.2, p.72-79, 2006.

SIQUEIRA, M.; PIETROCOLA, M. Curso de Física de Partículas para o Ensino Médio, 2007.

SIQUEIRA, M.; PIETROCOLA, M. Como a Física de Partículas Elementares pode contribuir para o ensino básico?. In: CARUSO, F.; OGURI, V.; SANTORO, A. (Org.). O que são Quarks, Glúons, Higgs, Buracos Negros e outras coisas Estranhas?. São Paulo: Livraria da Física, 2011, p. 263-284.

SIQUEIRA, M.; PIETROCOLA, M. Teacher education in the context of modern and contemporary physics: an experience with public system teachers. In: The World Conference on Physics Education, 2012, Istambul. The World Conference on Physics Education. Istambul: WCPE, 2012.

SMALL, G.; VORGAN, G. iBrain: Surviving the Technological Alteration of the Modern Mind. New York: Harper Collins Publishers, 2008.

SMITH, H. J.; HIGGINS, S.; WALL, K.; MILLER, J. Interactive whiteboards: boon or bandwagon? A critical review of the literature. Journal of Computer Assisted Learning, v. 21, n. 2, p. 91-101, 2005.

SOUSA, W. B. Física das Radiações: Uma Proposta para o Ensino Médio. 2009. 239 f. Dissertação (Mestrado Interunidades em Ensino de Ciências), Universidade de São Paulo, São Paulo.

SOUSA, W. B.; PAIVA, J. R.; UETA, N.; PIETROCOLA, M. Report on the introduction of one experimental activity for the abstract content of modern and 
contemporary physics in high school. In: International Conference on Physics Education, 2007, Marrakech. International Conference on Physics Education. Marrakech: ICPE, 2007.

STANNARD, R. Modern physics for the young. Physics Education, Bristol, v. 25, n. 3, p. $133,1990$.

SWINBANK, E. Particle Physics: a new course for schools and colleges. Physics Education, Bristol, v. 27, n. 2, p. 87-91, 1992.

TABER, K. Learning Quanta: barriers to stimulating transitions in student understanding of orbital ideas. Science Education, v.89, n.1. p.94-116, 2004.

TAYLOR, E. F.; VOKOS, S.; O'MEARA, J. M.; THORNBER, N. S., Teaching Feynman's sum-over-paths quantum theory, Computers in Physics, Nova York, v. 12, n. 2, p. 190-199, 1998.

TERRAZZAN, E. A. A inserção da física moderna e contemporânea no ensino de física na escola de $2^{\circ}$ grau. Caderno Catarinense de Ensino de Física, Florianópolis, v. 9, n. 3, p. 209-214, 1992.

UTGES, G. Modelos e Analogias na compreensão do conceito de ondas. 1999. Tese (Doutorado em Educação) - Faculdade de Educação. Universidade de São Paulo, São Paulo. 1999.

VALK, T. V. D.; DRIEL, J. H. V.; DE VOS, W. Common characteristics of models in present-day scientific practice. Research in Science Education, Queensland, v. 37, n.4, p. 469-488, 2007.

WATSON, D. M. Pedagogy before technology: Re-thinking the relationship between ICT and teaching. Education and Information technologies, v. 6, n.4, p. 251-266, 2001.

WEBB, M. E. Affordances of ICT in science learning: implications for an integrated pedagogy. International Journal of Science Education. Londres, v. 27, n. 6, p. 705-735, 2005.

WHITELOCK, D.; TAYLOR, J., O'SHEA, T.; SCANLON, E.; SELLMAN, R.; CLARK, P.; O'MALLEY, C., Challenging models of elastic collisions with a computer simulation. Computers \& Education, Oxford, v. 20, n. 1, p. 1-9, 1993. 
WILSON, B. Particle physics at A-level-a theacher's viewpoint. Physics Education, Bristol, v. 27, n. 2, p. 64-65, 1992.

XIA, J.; FIELDER, J.; SIRAGUSA, L. Achieving better peer interaction in online discussion forums: A reflective practitioner case study. Issues in Educational Research, v. 23, n. 1, p. 97-113, 2013.

YAMAMOTO, I.; BARBETA, V. B. Simulações de experiências como ferramenta de demonstração virtual em aulas de teoria de Física. Revista Brasileira de Ensino de Física, São Paulo, v. 23, n. 2, p. 215-225, 2001. 


\section{APÊNDICES}

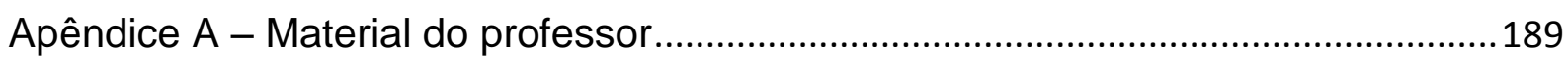

Apêndice B - Material do Aluno (Dossiê) ......................................................................223 


\section{APÊNDICE A - MATERIAL DO PROFESSOR}




\section{De Thomson aos Aceleradores de Partículas}

Material do professor 


\section{APRESENTAÇÃO}

O curso "De Thomson aos aceleradores de partículas" foi desenhado por meio de uma parceria entre o Núcleo de Pesquisa em Inovação Curricular (NUPIC) da Faculdade de Educação da Universidade de São Paulo e o Centre de Recerca per a l'Educació Científica i Matemática (CRECIM) da Universitat Autònoma de Barcelona. Após a aplicação do curso com alunos da Educação Secundária da Catalunha (Espanha) e alunos do Ensino Médio paulista, foi elaborado este material, que serve como guia ao professor para que a mesma prática possa ser realizada com outros alunos. O curso possui 4 horas de duração, mas pode ser adaptado pelo professor para ser desenvolvido ao longo de 4 ou 5 aulas.

O curso, além de permitir uma discussão sobre a estrutura da matéria e sobre os aceleradores de partículas e sua técnica, constitui-se como uma introdução à Física de Partículas em nível médio. No curso são analisadas e discutidas diferentes maneiras para se descobrir o que há no interior da matéria. Após uma breve discussão sobre o uso dos Raios $\mathrm{X}$ obtidos em um acelerador de partículas, é previsto que os alunos trabalhem com um experimento analógico e, em seguida, utilizem algumas simulações computacionais na discussão de modelos atômicos e do experimento de GeigerMarsden. Ao final é visto como o mesmo método utilizado no experimento analógico e no experimento histórico de Geiger e Marsden é empregado atualmente nos aceleradores de partículas.

Todas as atividades foram pensadas para serem realizadas com a turma dividida em grupos com 3 ou 4 alunos. Cada grupo deverá ter a sua disposição um computador que permita o acesso às simulações, e cada aluno do grupo deverá receber um roteiro de perguntas em papel (dossiê). Em geral, as atividades seguem uma sequência em que inicialmente os alunos devem ler o texto da atividade e as questões propostas, para em seguida discuti-las em seu grupo e respondê-las no roteiro em papel; por fim, o professor e os alunos deverão discutir em conjunto. Caberá ao professor mediar as discussões e direcioná-las, apresentando novos exemplos e ressaltando o que na fala dos alunos pode ser considerado como correto. Além disso, o professor deverá ficar à disposição dos alunos durante as discussões em grupo, auxiliando-os no caso de dúvidas.

Neste guia do professor estão disponíveis os textos e imagens que são utilizadas no curso, e são indicados os links para as simulações computacionais. Um quadro sintético da prática com uma breve descrição de cada atividade e o tempo previsto é apresentado a seguir:

\begin{tabular}{|c|c|c|}
\hline Atividade & $\begin{array}{c}\text { Tempo } \\
\text { previsto }\end{array}$ & \multicolumn{1}{|c|}{ Breve descrição } \\
\hline I & 25 minutos & $\begin{array}{l}\text { Apresentação da prática e motivação para o estudo do tema a partir de um } \\
\text { relato de uma pesquisa envolvendo Raios X obtidos em um acelerador de } \\
\text { partículas. }\end{array}$ \\
\hline II & 45 minutos & $\begin{array}{l}\text { Experimento analógico que busca demonstrar que é possível obter } \\
\text { informações indiretamente de um objeto desconhecido ou oculto. }\end{array}$ \\
\hline III & 20 minutos & Intervalo \\
\hline IV & 100 minutos & $\begin{array}{l}\text { Discussão envolvendo a superação do modelo atômico de Thomson a partir } \\
\text { do experimento de Geiger-Marsden, e sobre a adequação de um modelo } \\
\text { atômico com um núcleo positivo (modelo atômico de Rutherford). }\end{array}$ \\
\hline V & 25 minutos & $\begin{array}{l}\text { Comparação entre a técnica utilizada no experimento analógico e no } \\
\text { experimento de Geiger-Marsden. }\end{array}$ \\
\hline & 25 minutos & $\begin{array}{l}\text { Discussão sobre os aceleradores de partículas e sobre a técnica empregada } \\
\text { neles. }\end{array}$ \\
\hline
\end{tabular}

A seguir, é apresentado um fluxograma do curso, com a indicação dos momentos previstos para a exposição do professor, para a interação da turma e para a realização das atividades. Após o fluxograma, são apresentadas descrições mais detalhadas de cada atividade e os texto previstos de serem utilizados. 


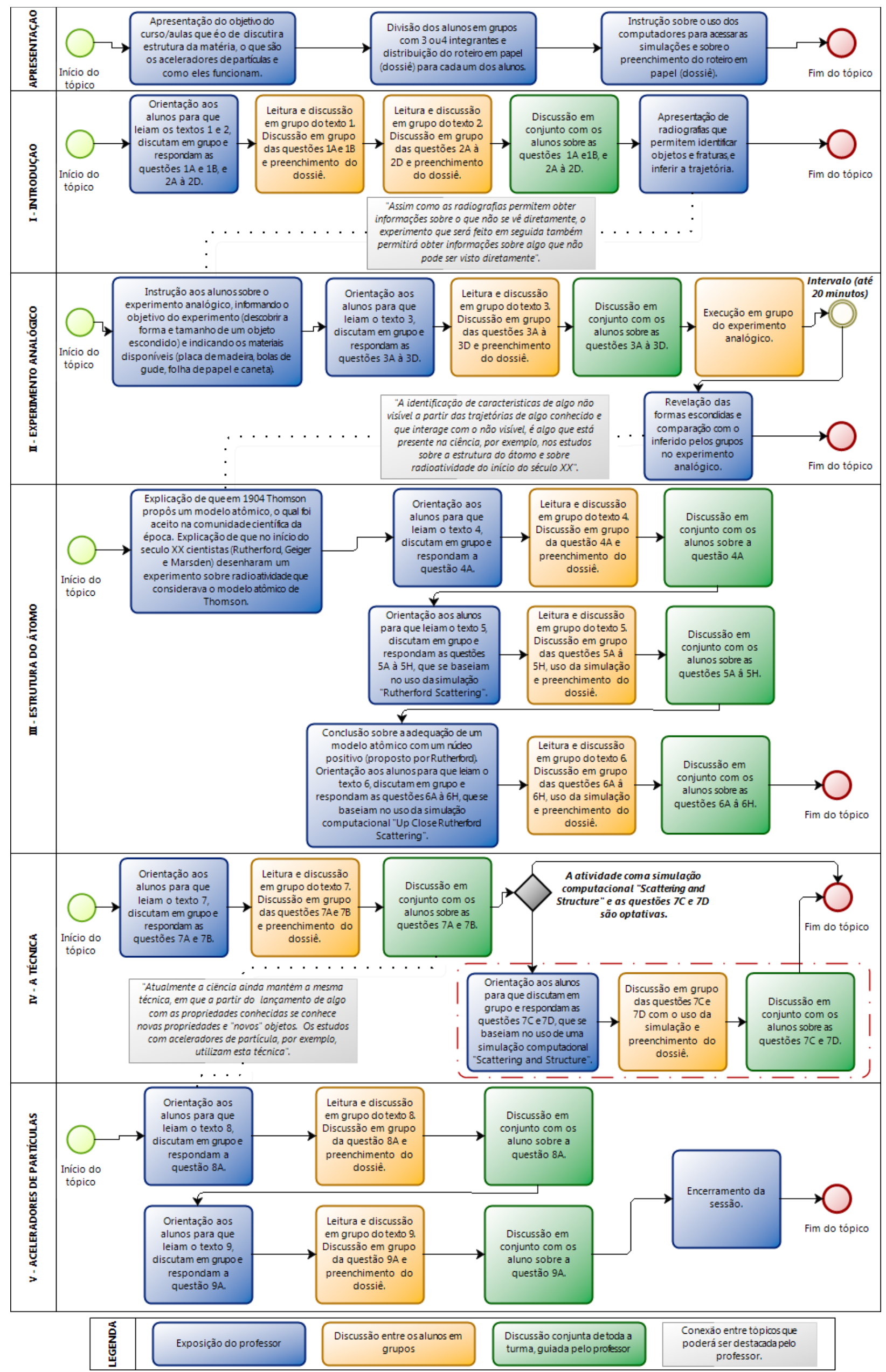




\section{ATIVIDADE I - INTRODUÇÃO}

\section{OBJETIVO:}

Com esta atividade pretende-se motivar os alunos para o estudo sobre os aceleradores de partículas e, ao mesmo tempo, introduzir alguns aspectos que serão retomados ao longo da prática. Partindo de um relato de um estudo realizado por cientistas, no qual é empregado um acelerador de partículas para a análise da estrutura de uma proteína utilizada no controle do colesterol, objetiva-se demonstrar a importância em conhecer o interior e a estrutura da matéria.

\section{CONTEÚDO FÍSICO:}

- Radiação eletromagnética - Frequência, comprimento de onda e energia;

- Raios X e espectro visível;

- Relação entre comprimento de onda dos Raios X e a resolução de radiografias;

- Relação entre o comprimento de onda da radiação eletromagnética e a penetrabilidade na matéria.

\section{RECURSOS:}

- Material com instruções para o professor (este material) e roteiro em papel que deverá ser preenchido pelos alunos;

- Texto 1, que traz um resumo de uma notícia publicada no ano de 2011 e algumas questões;

- Texto 2 com imagens de uma fotografia e de uma radiografia da mão e algumas questões.

\section{MOMENTOS SUGERIDOS:}

\section{APRESENTAÇÃO DO CURSO}

Como a Atividade I é a primeira do curso sobre os aceleradores de partículas, procure apresentar brevemente a ideia do curso, que é a de responder duas perguntas: "O que são os aceleradores de partículas?" e "Como é a técnica empregada nas pesquisas com aceleradores de partículas?". Também instrua os alunos sobre o acesso às simulações e aos textos que serão utilizados.

Após, divida os alunos em grupos de 3 ou 4 integrantes. A formação dos grupos deve ser mantida até o final do curso. Após a formação dos grupos, entregue a cada um dos alunos o roteiro em papel pelo qual eles responderão as questões que são propostas. Ainda que cada aluno de cada grupo receba o seu roteiro, motive os alunos a discutirem em grupo cada uma das perguntas antes de fornecerem suas respostas escritas. 


\begin{tabular}{|c|c|}
\hline \multirow[b]{2}{*}{ 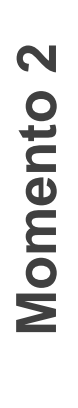 } & MOTIVAÇÃO - TEXTOS 1 E 2 \\
\hline & $\begin{array}{l}\text { Nesse momento, os alunos devem se dedicar inicialmente a leitura do texto } 1 \text {, Os } \\
\text { raios } X \text { ajudam a ganhar a batalha contra as doenças do coração. Em grupo eles devem } \\
\text { discutir as questões propostas ( } 1 \mathrm{~A} \text { e } 1 \mathrm{~B} \text { ) e respondê-las no roteiro em papel. } \\
\text { Logo após, os alunos deverão se dedicar à leitura do texto } 2 \text {, Uma "fotografia } \\
\text { especial". Também em grupo eles devem discutir as questões propostas (2A a } 2 \mathrm{D} \text { ) e } \\
\text { respondê-las no roteiro em papel }\end{array}$ \\
\hline \multirow[b]{2}{*}{ 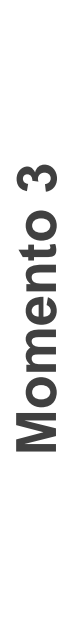 } & DISCUSSÃO GERAL \\
\hline & $\begin{array}{l}\text { Após os alunos discutirem em grupo e responderem as perguntas propostas } \\
\text { relacionadas aos dois textos, promova uma discussão conjunta com toda a turma, } \\
\text { recapitulando o que é apresentado nos textos, e direcionando as discussões de forma a tornar } \\
\text { evidente algumas respostas corretas possíveis para as perguntas propostas. } \\
\text { Durante as discussões, ao abordar as radiografias, apresente outras aos alunos } \\
\text { imagens de outras radiografias, que podem ser obtidas facilmente na internet. Podem ser } \\
\text { utilizadas radiografias que permitem identificar fraturas, objetos no interior do corpo, ou mesmo } \\
\text { trajetórias, como as radiografias utilizadas em perícias forenses sobre balística. A discussão } \\
\text { sobre as radiografias que são apresentadas, em especial aquelas que permitem verificar } \\
\text { alguma trajetória (balística), servirá de link para a próxima atividade, que trata justamente de } \\
\text { uma análise de trajetórias. }\end{array}$ \\
\hline
\end{tabular}




\section{TEXTO 1 - OS RAIOS X AJUDAM A GANHAR A BATALHA CONTRA AS DOENÇAS DO CORAÇÃO*}

Um grupo de cientistas do Imperial College de Londres revelou a estrutura da proteína ASBTnm, um dos componentes dos medicamentos que lutam contra o excesso de colesterol. Isto foi possível graças aos Raios X obtidos no acelerador de partículas europeu Síncroton ESRF, localizado em Grenoble, na França.

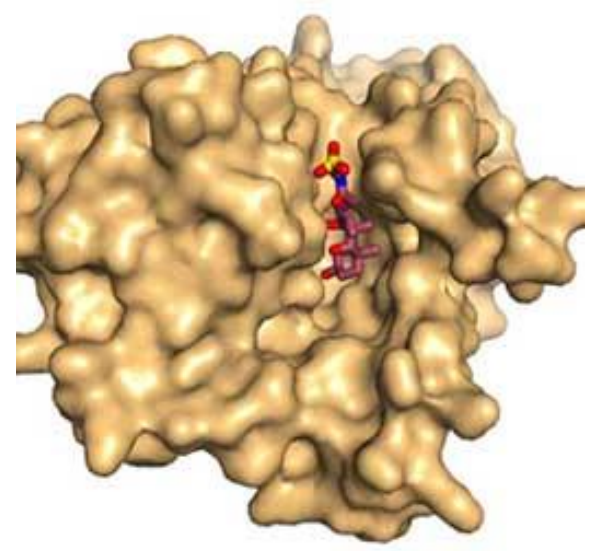

Representação da superfície da proteína ASBTnm (Fonte da imagem: diamond.ac.uk)

A determinação da estrutura desta proteína é essencial para desenhar medicamentos que sejam mais efetivos na luta contra os altos níveis de colesterol, que têm influência direta no surgimento de doenças do coração. Para que o medicamento seja mais efetivo é necessário que a proteína ASBTnm tenha a "forma" mais adequada para poder interagir com as gorduras presentes na comida que ingerimos, e desta maneira reduzir os níveis de colesterol no sangue.

\section{- Complete o seu dossiê:}

1A. Em sua opinião, por que é importante "ver" o interior de um objeto?

1B. De que maneiras você acha que é possível "ver" o interior de um objeto?

\footnotetext{
* Atividade baseada na matéria em inglês "X-rays help advance the battle against heart disease"' publicada em 05/10/2011 no site da Lightsource.org. Disponível em http://www.lightsources.org/press-release/2011/10/05/x-rays-help-advance-battleagainst-heart-disease
} 


\section{TEXTO 2 - UMA "FOTOGRAFIA ESPECIAL"}

Observe as figuras abaixo e após responda as questões:

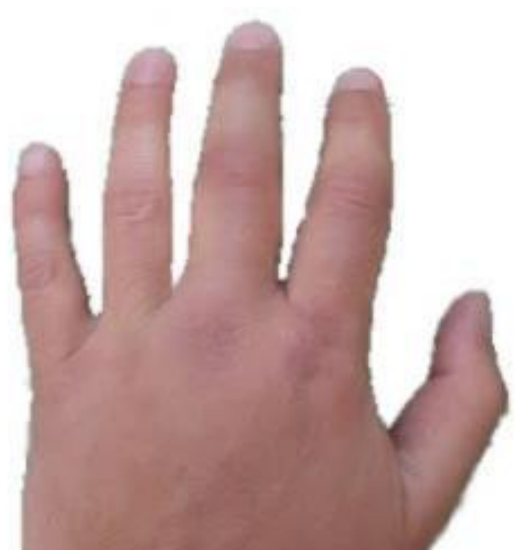

Fotografia de uma mão (Fonte da imagem: arquivo pessoal de membros do CRECIM)

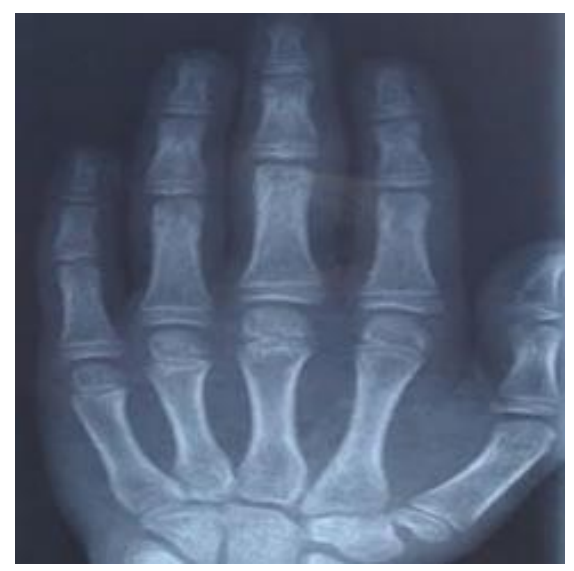

Radiografia de uma mão (Fonte da imagem: arquivo pessoal de membros do CRECIM)

\section{- Complete o seu dossiê:}

2A. O que você vê na fotografia? E na radiografia?

2B. Como os aparelhos de Raios X obtêm imagens dos ossos da mão?

2C. Para você, qual é a diferença entre a radiação que se utiliza para fazer uma fotografia e a radiação utilizada para fazer uma radiografia?

2D. Como se pode conseguir radiografias com mais detalhes?

Wilhem Konrad Röntgen descobriu em 1894 os Raios $X$ de maneira acidental. Com esta radiação, Röntgen podia ver o que havia sob a pele de uma pessoa. Enquanto a pele é opaca à luz visível e o ar é transparente a ela, os tecidos ósseos são opacos aos Raios $X$ e os tecidos moles são transparentes a eles. Com os Raios $X$ podemos "observar" o interior do corpo humano por meio de radiografias. Os Raios $X$ nos permitem ver fraturas dos ossos, objetos presentes no interior do corpo humano, etc.

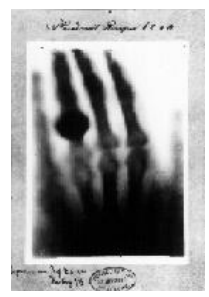

Imagem da mão da esposa de Röntgen. Primeira radiografia da história (Fonte da imagem: commons.wikimedia.org) 


\section{ATIVIDADE II - EXPERIMENTO ANALÓGICO}

\section{OBJETIVO:}

Este experimento analógico possui como objetivo demonstrar que é possível obter informações de um objeto desconhecido e/ou oculto, quando se lança contra ele objetos com propriedades conhecidas. Assim, a atividade permitirá introduzir a técnica que foi utilizada por Geiger-Marsden em seu experimento, e que levou Rutherford a rejeitar o modelo atômico de Thomson. A mesma técnica é utilizada atualmente nos aceleradores de partículas.

\section{CONTEÚDO FÍSICO:}

- Colisões mecânicas;

- Técnica de obtenção de informações a partir de trajetórias.

\section{RECURSOS:}

- Material com instruções para o professor (este material) e roteiro em papel que deverá ser preenchido pelos alunos;

- Texto 3 contendo instruções sobre a atividade e algumas questões;

- Placas de madeira com desenhos de figuras geométricas em relevo na parte inferior da placa';

- Bolas de gude de dois tamanhos;

- Folhas de papel e canetas para o desenho de trajetórias.

\section{MOMENTOS SUGERIDOS:}

\section{APRESENTAÇÃO DA ATIVIDADE}

\begin{tabular}{|c|c|}
\hline & APRESENTAÇÃO DA ATIVIDADE \\
\hline 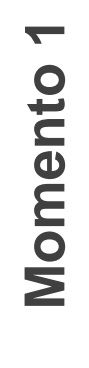 & $\begin{array}{l}\text { Em continuação à atividade anterior, você poderá comentar que os Raios X e } \\
\text { radiografias (como as que permitem observar trajetórias) podem ser utilizados para se obter } \\
\text { informações sobre o interior da matéria. Comente que os cientistas utilizam também outras } \\
\text { técnicas, como a que estará envolvida no experimento que será feito. Apresente o } \\
\text { experimento informando que cada um dos grupos terá à sua disposição um objeto escondido } \\
\text { abaixo de uma placa de madeira, e que eles deverão descobrir, sem olhar, a forma e o } \\
\text { tamanho do objeto. Informe que eles terão a sua disposição bolas de gude de dois tamanhos, } \\
\text { folhas de papel e canetas. }\end{array}$ \\
\hline
\end{tabular}

\footnotetext{
'Uma descrição sobre o experimento analógico e sua montagem pode ser obtida no artigo "Espalhamento de Rutherford na sala de aula do Ensino Médio", de autoria dos professores Maxwell Siqueira e Maurício Pietrocola, publicado na revista A Física na Escola. Disponível em: <http://www.sbfisica.org.br/fne/Vol11/Num2/a04.pdf>.
} 


\begin{tabular}{|c|c|}
\hline \multirow{2}{*}{ 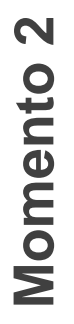 } & DESENHO DO EXPERIMENTO \\
\hline & $\begin{array}{l}\text { Para fazer a atividade, que se baseia no texto 3, "Outra maneira de "ver"', os alunos } \\
\text { deverão inicialmente efetuar o desenho do experimento, isto é, definir a técnica que utilizarão } \\
\text { baseado nos materiais que têm a sua disposição. Assim, os alunos deverão discutir em grupo } \\
\text { a técnica, e responder as questões propostas (3A a 3D). }\end{array}$ \\
\hline \multirow[b]{2}{*}{ 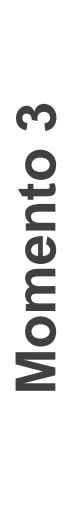 } & DISCUSSÃO CONJUNTA SOBRE O DESENHO EXPERIMENTAL \\
\hline & $\begin{array}{l}\text { Após cada grupo responder as perguntas e definir um desenho experimental, guie uma } \\
\text { discussão conjunta com o intuito de identificar as propostas de cada grupo e direcionar para o } \\
\text { desenho experimental mais adequado (veja o gabarito). Neste momento, alguns alunos } \\
\text { poderão ser convidados para explicarem no quadro negro a técnica proposta por seu grupo. } \\
\text { Durante a discussão das técnicas, procure direcioná-las à observação das trajetórias, e } \\
\text { destaque a utilidade da noção de tangente ao analisar as trajetórias envolvendo colisões em } \\
\text { superfícies não retas. Uma vez que seja estabelecido nas discussões que as trajetórias das } \\
\text { bolas de gude serão importantes, ressalte que as folhas de papel e as canetas deverão ser } \\
\text { utilizadas para registrar as trajetórias e para fazer o desenho da forma escondida. }\end{array}$ \\
\hline \multirow{2}{*}{ 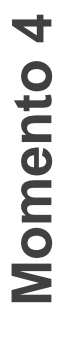 } & EXECUÇÃO DO EXPERIMENTO \\
\hline & $\begin{array}{l}\text { Após a discussão em conjunto com os alunos, e uma vez definido o desenho } \\
\text { experimental mais adequado, os alunos deverão realizar o experimento em seus grupos. Se } \\
\text { dois grupos terminarem o experimento (identificando uma possível forma), eles deverão trocar } \\
\text { as placas de madeira e executar novamente o experimento. Recomendamos que o grupo que } \\
\text { receber a placa não veja o resultado obtido pelo outro grupo. }\end{array}$ \\
\hline \multirow[b]{2}{*}{ 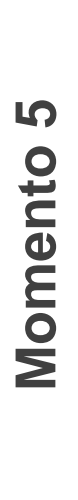 } & REVELAÇÃO DAS FORMAS \\
\hline & $\begin{array}{l}\text { Após executados os experimentos, apresente à turma os resultados obtidos (desenhos } \\
\text { das formas inferidos) e revele as formas escondidas para os estudantes. Ressalte mais uma } \\
\text { vez a técnica utilizada e destaque a semelhança que deverá ocorrer nos resultados de dois } \\
\text { grupos que analisam uma mesma forma escondida. } \\
\text { Neste momento, compare o trabalho efetuado pelos estudantes com a própria prática } \\
\text { científica, em que grupos de pesquisa realizam experimentos e chegam a resultados que } \\
\text { podem ser confirmados ou não por outros grupos de pesquisa que venha a desenvolver o } \\
\text { mesmo experimento. }\end{array}$ \\
\hline
\end{tabular}




\section{TEXTO 3 - OUTRA MANEIRA DE "VER"}

Os raios $X$ também permitem observar a estrutura de diferentes objetos. Mas os cientistas também utilizam outro método para ver, por exemplo, a estrutura dos componentes elementares da matéria: disparar partículas contra o objeto a ser estudado. As partículas interagem com o objeto originando um "mapa" que mostra as trajetórias seguidas por elas. A partir do estudo das trajetórias, os cientistas são capazes de analisar a forma e a estrutura do objeto.

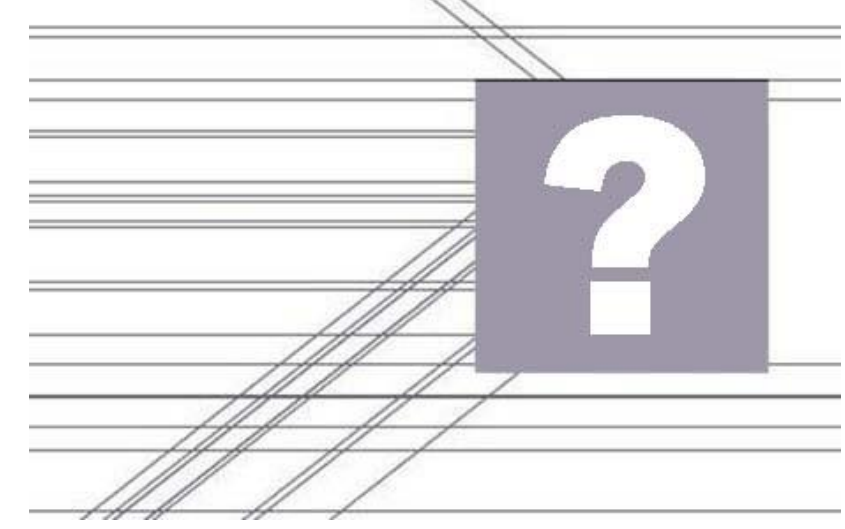

Você encontrará sobre a mesa uma placa quadrada de madeira que possui algo escondido abaixo dela. A sua tarefa agora consiste em descobrir a forma e a medida do objeto escondido sem vê-lo. Para isso, você poderá utilizar somente algumas bolas de gude, e utilizar folhas de papel e canetas para fazer anotações e desenhos.

Antes de iniciar o experimento, desenhe um método experimental para poder descobrir a forma e a medida do objeto desconhecido.

\section{- Complete o seu dossiê:}

3A. Como você determinará o tamanho do objeto?

3B. Como você descobrirá a forma do objeto?

3C. Como você detectará se os objetos têm detalhes menores?

3D. Como você poderia confirmar as tuas conclusões sobre a forma e a medida do objeto sem vê-lo?

Após definir o desenho experimental, inicie o experimento para tentar descobrir a forma e o tamanho do objeto. 


\section{ATIVIDADE III - ESTRUTURA DO ÁTOMO}

\section{OBJETIVO:}

O objetivo desta atividade é demonstrar que a mesma técnica utilizada no experimento analógico, executado na atividade anterior, está presente na prática científica e foi importante historicamente no estudo da estrutura atômica.

\section{CONTEÚDO FÍSICO:}

- Modelo atômico de Thomson;

- Experimento de Geiger-Marsden;

- Modelo atômico de Rutherford;

- Lei de Coulomb.

\section{RECURSOS:}

- Material com instruções para o professor (este material) e roteiro em papel que deverá ser preenchido pelos alunos;

- Texto 4 sobre o modelo de Thomson e a predição do experimento de GeigerMarsden, com uma questão;

- Texto 5 sobre o experimento de Geiger-Marsden e o espalhamento de Rutherford, com algumas questões;

- Simulação computacional "Rutherford Scattering", sobre o experimento de GeigerMarsden, a ser utilizada em conjunto com o Texto 5;

- Texto 6 sobre o modelo de átomo com um núcleo, com algumas questões;

- Simulação computacional "Up Close Rutherford Scattering", sobre a interação de partículas alfa com o núcleo do átomo de Rutherford, a ser utilizada em conjunto com o Texto 6.

\section{MOMENTOS SUGERIDOS:}

\section{APRESENTAÇÃO DA ATIVIDADE}

Comente com os alunos que a técnica de se obter informações de algo desconhecido quando este interage com um objeto conhecido é comum na ciência, e que historicamente está presente na discussão dos modelos atômicos, que teve seu auge no início do século XX. Comente que nesta atividade será visto como o experimento executado por Geiger e Marsden, sob a supervisão de Rutherford, foi importante na discussão dos modelos atômicos. 


\begin{tabular}{|c|c|}
\hline \multirow{2}{*}{ 象 } & PREDIÇÃO RELACIONADA AO MODELO DE THOMSON \\
\hline & $\begin{array}{l}\text { Após a apresentação da atividade, os alunos deverão se dedicar à leitura do texto } 4 \text {, } \\
\text { "Modelo de Thomson", e a responder a questão } 4 \text { A proposta, relacionada ao que Rutherford } \\
\text { possivelmente esperava para a interação entre as partículas alfa e o átomo segundo o modelo } \\
\text { atômico de Thomson. }\end{array}$ \\
\hline \multirow[b]{2}{*}{$\begin{array}{l}\infty \\
\frac{1}{2} \\
\frac{E}{2}\end{array}$} & DISCUSSÃO CONJUNTA SOBRE A PREDIÇÃO \\
\hline & $\begin{array}{l}\text { Discuta com os alunos a questão 4A. Permita aos alunos apresentarem suas } \\
\text { respostas e promova a discussão conjunta com toda a turma a partir destas. Na discussão, } \\
\text { procure identificar e corrigir possíveis noções incorretas sobre o átomo de Thomson e sobre o } \\
\text { comportamento de partículas alfa lançadas contra um átomo de Thomson. Ao discutir a } \\
\text { interação entre as partículas alfa e o átomo de Thomson, procure explicar o porquê dos } \\
\text { pequenos desvios que podem ser observados no mapa de trajetória apresentado na imagem } \\
\text { que antecede a questão 4A. }\end{array}$ \\
\hline \multirow{2}{*}{ 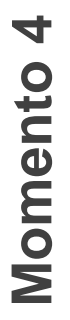 } & APRESENTAÇÃO DO EXPERIMENTO DE GEIGER-MARSDEN \\
\hline & $\begin{array}{l}\text { Após, apresente brevemente o experimento de Geiger-Marsden, descrevendo cada } \\
\text { parte e relacionando com a imagem da simulação computacional que será utilizada logo em } \\
\text { seguida. }\end{array}$ \\
\hline \multirow{2}{*}{ 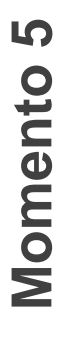 } & SIMULAÇÃO DO EXPERIMENTO DE GEIGER-MARSDEN \\
\hline & $\begin{array}{l}\text { Os alunos deverão se dedicar à leitura do texto } 5 \text {, "O espalhamento de Rutherford", e } \\
\text { responder as questões propostas em que devem fazer uma predição dos resultados do } \\
\text { experimento de Geiger-Marsden ( } 5 \mathrm{~A} \text { e } 5 \mathrm{~B} \text { ). Em seguida, devem utilizar a simulação deste } \\
\text { experimento (Rutherford Scattering) para responder as demais questões propostas (5C à } \\
5 \mathrm{H} \text { ). }\end{array}$ \\
\hline \multirow[b]{2}{*}{ 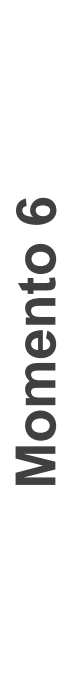 } & $\begin{array}{l}\text { DISCUSSÃO CONJUNTA SOBRE O EXPERIMENTO DE GEIGER- } \\
\text { MARSDEN }\end{array}$ \\
\hline & $\begin{array}{l}\text { Após o uso da simulação do experimento de Geiger-Marsden e após os alunos } \\
\text { responderem as perguntas relacionadas a este experimento, inicie uma discussão conjunta } \\
\text { com toda a turma. Durante as discussões, ressalte o fato do modelo de átomo de Thomson } \\
\text { não se apresentar como adequado para explicar os resultados experimentais (desvios com } \\
\text { grandes ângulos), e a necessidade de um novo modelo de átomo. } \\
\text { A questão } 5 \mathrm{H} \text { consiste justamente em representar o átomo segundo uma proposta de } \\
\text { um novo modelo atômico. Assim, para facilitar as discussões, solicite que alguns alunos } \\
\text { desenho no quadro negro suas propostas. A partir dos desenhos e considerando os } \\
\text { resultados do experimento de Geiger-Marsden simulado, procure argumentar com os alunos a } \\
\text { viabilidade de uma noção de átomo com uma região nuclear, onde se concentra a carga } \\
\text { positiva, noção esta que será aprofundada no próximo momento. }\end{array}$ \\
\hline
\end{tabular}




\begin{tabular}{|c|c|}
\hline \multirow[b]{2}{*}{ 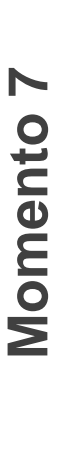 } & INTERAÇÃO DA PARTÍCULA ALFA COM O NÚCLEO DO ÁTOMO \\
\hline & $\begin{array}{l}\text { Os alunos deverão utilizar o texto } 6 \text {, "O átomo nuclear", e responder a questão } 6 \mathrm{~A} \text { que } \\
\text { envolve uma predição do comportamento da partícula alfa ao interagir com o núcleo de um } \\
\text { átomo. Em seguida, eles deverão utilizar a simulação que enfatiza esta interação (Up Close } \\
\text { Rutherford Scattering), para responder as demais questões propostas ( } 6 \mathrm{~B} \text { a } 6 \mathrm{H}) \text {. } \\
\text { Obs.: As questões optativas } 6 \mathrm{D} \text { e } 6 E \text {, ainda que sejam úteis para analisar o } \\
\text { comportamento de uma partícula alfa de acordo com a sua distância em relação ao núcleo, } \\
\text { poderão ser dispensadas em função de ajustes de tempo necessários. }\end{array}$ \\
\hline \multirow{2}{*}{ 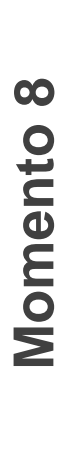 } & $\begin{array}{l}\text { DISCUSSÃO CONJUNTA SOBRE A INTERAÇÃO ENTRE A } \\
\text { PARTÍCULA ALFA E O NÚCLEO DO ÁTOMO }\end{array}$ \\
\hline & $\begin{array}{l}\text { Mais uma vez, dedique-se a discutir com os alunos as perguntas que foram } \\
\text { apresentadas no roteiro da atividade. Nas questões que tratam do desenho do gráfico da } \\
\text { interação e do desenho do vetor força elétrica, convide alguns dos alunos para fazer o } \\
\text { desenho no quadro negro. É possível que os desenhos reflitam algumas concepções } \\
\text { espontâneas incorretas, como na questão } 6 \mathrm{~F} \text { em que podem atribuir ao vetor força, sentidos e } \\
\text { intensidades esperados para o vetor velocidade. Neste caso, recorra a uma breve explicação } \\
\text { que permita a superação de tais concepções. }\end{array}$ \\
\hline
\end{tabular}




\section{TEXTO 4 - MODELO DE THOMSON}

Anteriormente nós vimos algumas estratégias que podem ser utilizadas para conhecer a forma, a medida e a estrutura do interior de um objeto ou de algo escondido, de uma substância ou, em geral, da matéria. Uma das aventuras mais emocionantes que podemos encontrar na história da ciência é a busca por entender como é o interior da matéria. Esta busca esteve paralela a outros descobrimentos que permitiram aos cientistas propor modelos cada vez mais explícitos das evidências que eram descobertas. Röntgen descobriu os Raios $X$ enquanto estudava os "raios catódicos" que, ao final do século XIX, constituía um dos principais campos de estudo da Física. Experimentos detalhados mostraram de maneira clara que os "raios catódicos" eram na realidade um feixe de partículas de carga negativa. O cientista J. J. Thomson demonstrou que estas partículas eram originárias do interior de todos os átomos, e ele as chamou de corpúsculos. Mais tarde estas partículas foram batizadas com o nome elétrons.

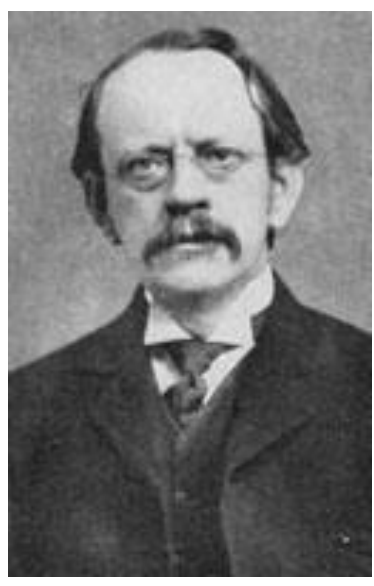

J. J. Thomson (Fonte da imagem:

commons.wikimedia.org)

Se o átomo até então indivisível continha em seu interior umas partículas menores (os elétrons), uma questão que surgia envolvia como os elétrons estavam colocados no interior do átomo, ou seja, qual era a estrutura dos átomos e como os elétrons estavam envolvidos nesta estrutura. Thomson propôs no ano de 1904 um modelo teórico que dava resposta a estas questões. Para Thomson, o átomo seria composto por uma esfera com carga positiva e com elétrons (de carga negativa) distribuídos em seu interior.

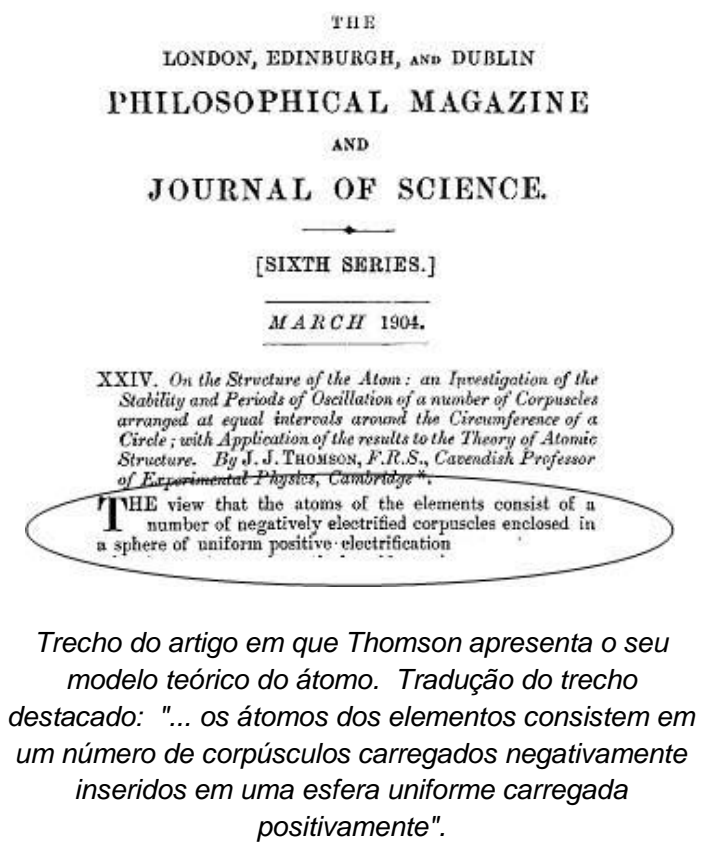

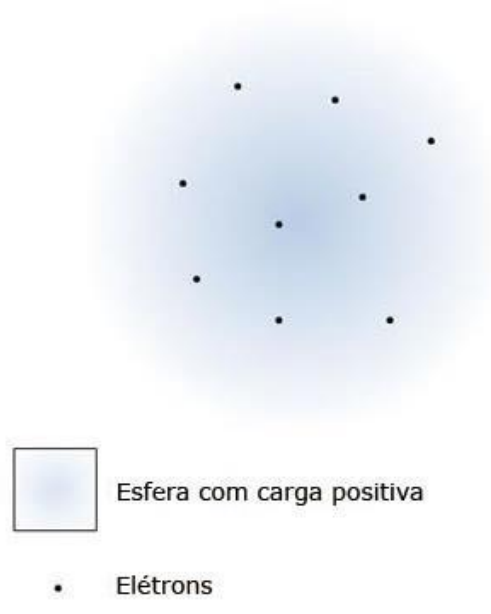

Representação do átomo segundo o modelo de Thomson 
Paralelamente, a princípios do século XX havia surgido outro importantíssimo campo de pesquisa: a radioatividade. $O$ cientista Rutherford e seus colegas Geiger e Marsden estavam estudando a radiação alfa quando encontraram alguns resultados, para eles, surpreendentes. A compreensão dos dados experimentais requeria estudar qual era a estrutura do átomo.

Rutherford, Geiger e Marsden desenharam um experimento que consistia em bombardear com partículas alfa, que possuem carga elétrica positiva, lâminas muito finas de um determinado metal como, por exemplo, o ouro. Para fazer as suas predições ele se baseava no modelo atômico aceito até então: o modelo atômico de Thomson.

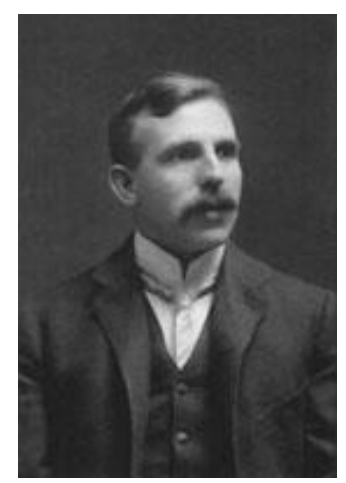

Rutherford (Fonte da imagem: commons.wikimedia.org)

Rutherford imaginava a trajetória das partículas alfa como algo semelhante ao apresentado no mapa de trajetórias abaixo:

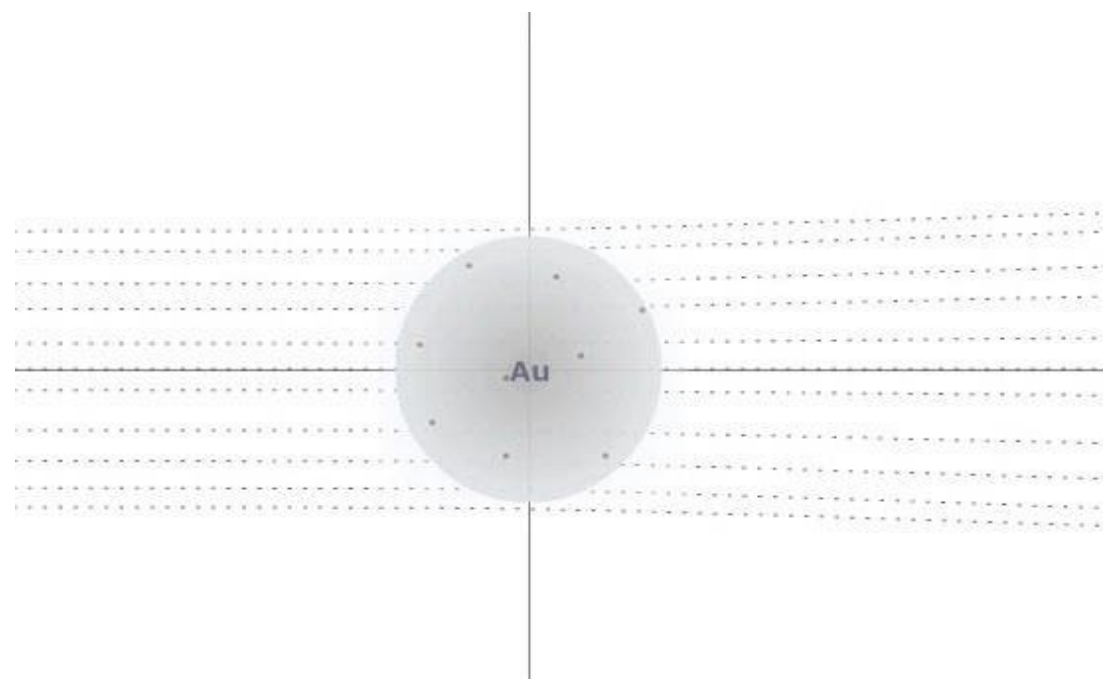

- Complete o seu dossiê:

4A. A partir da imagem do mapa de trajetórias, indique como você acha que Rutherford podia explicar:

- que as partículas alfa atravessavam o átomo;

- que quando as partículas alfa atravessavam o átomo se desviavam um pouco;

- que as partículas alfa que não atravessavam o átomo também se desviavam.

Ao estudar as trajetórias seguidas pelas partículas é possível obter evidências do modelo teórico de átomo envolvido, confirmando-o; ou mesmo, é possível obter dados contrários ao modelo teórico, refutando-o. Quando um modelo teórico é refutado por ser inadequado, outro é proposto, que seja capaz de explicar as antigas e as novas evidências que surgem dos novos resultados experimentais. 


\section{TEXTO 5 - O ESPALHAMENTO DE RUTHERFORD}

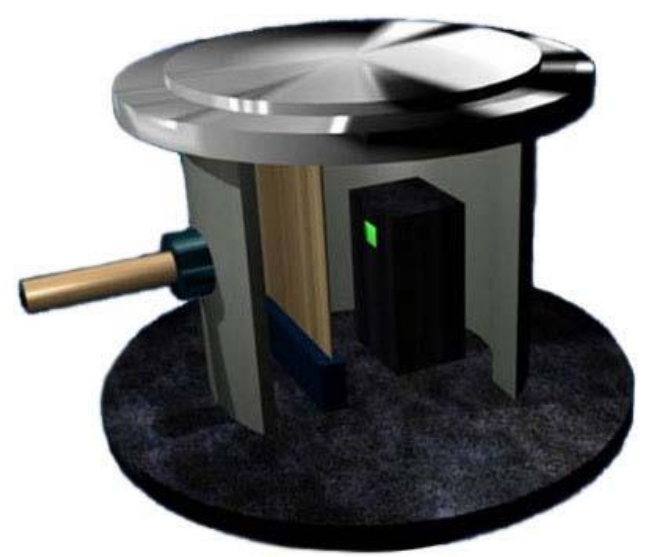

Representação do experimento utilizado por Geiger e Marsden (Imagem adaptada. Fonte da imagem original: kcvs.ca)

Para realizar o experimento que foi planejado, Geiger e Marsden utilizavam uma placa metálica, já que não poderia utilizar somente um átomo. Além disso, como não podia trabalhar com partículas alfa individuais, ele utilizou uma fonte radioativa que emitia muitas partículas alfa.

Quando Geiger e Marsden executaram este experimento, eles não podiam visualizar as trajetórias das diferentes partículas alfa, mas somente podia saber em que posição elas chegavam. Uma vez que as partículas alfa atravessam a placa metálica, elas incidiam sobre uma tela obtendo com isso um breve flash de luz, um centelhamento, que podia ser observado através de um visor móvel que podia ser colocado em diferentes posições (modificando o ângulo do visor em relação à horizontal). Após atravessar a placa metálica, as partículas alfa podiam se dispersar em diferentes ângulos. O número de flashs em certo ângulo poderia ser medido colocando-se o visor naquela posição.

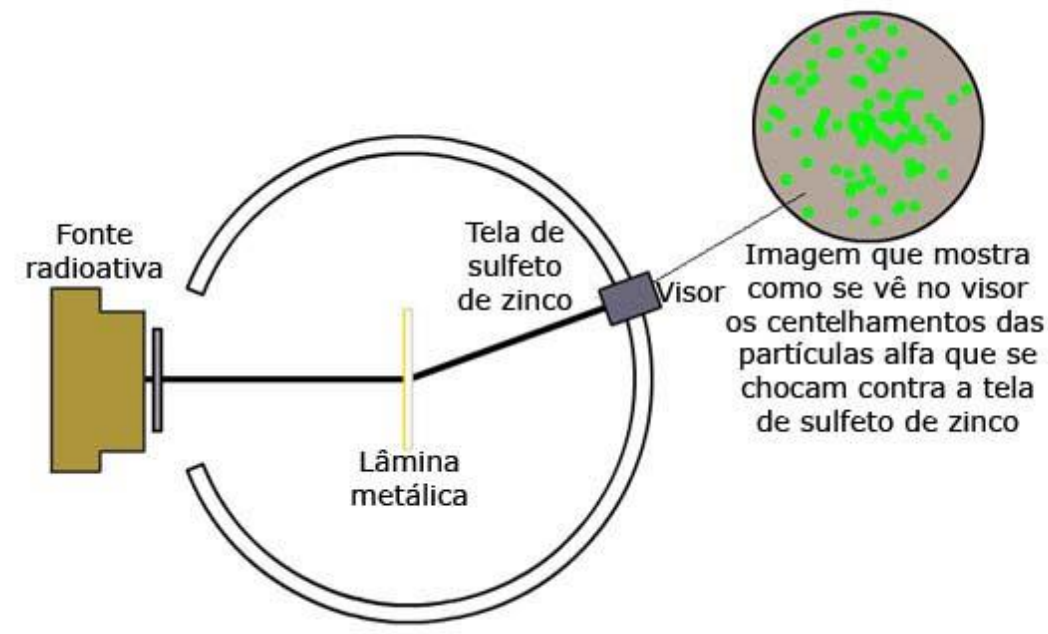

Montagem experimental

\section{- Complete o seu dossiê:}

5A. Tendo em conta o modelo de Thomson, em que ângulos deveria ser colocado o visor para se obter a maioria de flashes possíveis?

5B. Segundo o modelo de Thomson era esperado obter um flash com ângulos grandes? 


\section{- Simulação:}

Para comprovar a sua predição, utilizaremos uma simulação computacional do experimento de Geiger e Marsden. Configure a simulação com as seguintes opções:

- Element como gold;

- Alpha Energy (MeV) como 3.0 MeV.

Você deverá utilizar a simulação para responder as próximas questões desta página (5C à $5 \mathrm{H})$. Para iniciar ou parar a simulação, pressione o botão Fire Particles.

Simulação "Rutherford Scattering" disponível em http://www.kcvs.ca/site/projects/physics files/rutherford/historical scattering2.swf

\section{- Complete o seu dossiê:}

5C. O que se observa quando o visor é colocado com ângulos pequenos?

5D. O que se observa quando o visor é colocado com ângulos grandes?

5E. Como você explicaria os resultados obtidos quando o visor é colocado com ângulos grandes?

5F. Naquele momento histórico já se sabia que a partícula alfa era muito maior e mais massiva que os elétrons, e que ambos eram muitos menores que o átomo. A partir desta informação, você poderia acrescentar algo à explicação que você forneceu na questão anterior?

5G. Pode-se concluir que o modelo atômico de Thomson está de acordo com os resultados que foram obtidos com a simulação?

$5 \mathrm{H}$. (Predição) Faça uma proposta de um novo modelo de átomo baseando-se naquilo que você imagina que Rutherford propôs para explicar os resultados obtidos no experimento. Faça um esquema de sua proposta. 


\section{TEXTO 6 - O ÁTOMO NUCLEAR}

Como o modelo de Thomson não podia dar resposta aos resultados experimentais, Rutherford propôs uma nova hipótese sobre a estrutura do átomo. Para Rutherford, o padrão de dispersão obtido na interação entre as partículas alfa disparadas contra a folha metálica mostrava una nova estrutura atômica formada por um núcleo em meio a um grande espaço vazio, em que se encontravam os elétrons.

\section{- Complete o seu dossiê:}

6A. (Predição) O que acontece quando nos fixamos somente em um núcleo atômico? Imagine que fazemos um zoom dos bombardeios das partículas alfa lançadas contra os átomos e nos fixamos no que passa na zona próxima ao núcleo de um dos átomos. Como você acha que serão as trajetórias das partículas alfa? Represente-as no esquema abaixo, para seis partículas alfa em diferentes posições inicias.

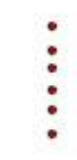

\section{- Simulação:}

A seguinte simulação computacional (Up Close Scattering) permitirá analisar a sua predição anterior. Pressione o botão Auto-fire e execute a simulação até observar um padrão de dispersão claro.

Recorde que para iniciar ou parar a simulação basta clicar sobre o botão Auto-fire.

Simulação "Up Close Rutherford Scattering" disponível em http://www.kcvs.ca/site/projects/physics files/rutherford/scattering2.swf

\section{- Complete o seu dossiê:}

6B. Compare a predição que você fez na questão anterior com os resultados da simulação. Que diferenças e semelhanças existem?

Quando as partículas alfa se aproximam do núcleo, elas seguem trajetórias em que sua direção se modifica. A mudança na direção do movimento de uma partícula é consequência de algum tipo de interação ou força. Considere isso para responder as próximas questões. 


\section{- Complete o seu dossiê:}

6C. Que forças atuam sobre a partícula alfa quando esta se aproxima do núcleo?

6D. (OPTATIVA) Selecione na simulação anterior uma energia de $15 \mathrm{MeV}$ e um parâmetro de impacto de $0,0 \mathrm{fm}$. Pressione o botão Fire. No gráfico a seguir, faça uma predição qualitativa da força que atua sobre a partícula alfa em função da distância ao núcleo.

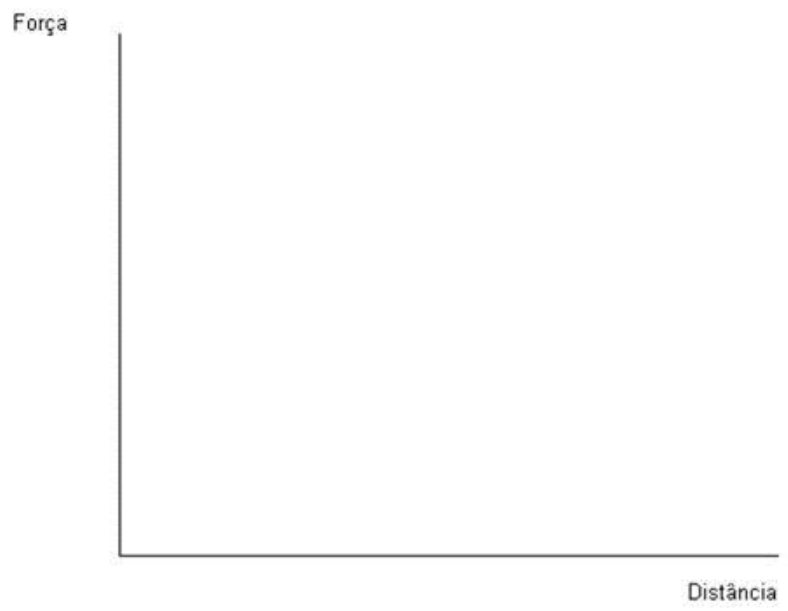

6E. (OPTATIVA) Compare a sua predição com o gráfico montado pela simulação. Para isso, selecione no menu Options o item Show Graph. Que diferenças existem?

6F. Selecione um valor de $5.0 \mathrm{fm}$ para o parâmetro de impacto e clique no botão Fire. Você deverá obter algo semelhante à figura abaixo. Na figura abaixo, desenhe o vetor força elétrica atuante sobre a partícula alfa para três posições específicas dessa partícula: uma próxima ao início da trajetória (mais à esquerda), uma próxima ao núcleo e outra após o desvio.

6G. Como você mudaria a trajetória e o esquema de forças anterior se a carga do núcleo fosse menor? Após responder, mantendo um valor de $5.0 \mathrm{fm}$ para o parâmetro de impacto, comprove sua resposta selecionando na simulação o elemento alumínio, o qual possui um núcleo com uma carga elétrica menor.

$6 \mathrm{H}$. Sem utilizar a simulação, o que você acha que ocorreria se mudássemos a energia das partículas alfa incidentes? 


\section{ATIVIDADE IV - A TÉCNICA}

\section{OBJETIVO:}

Esta atividade tem como objetivo retomar brevemente a técnica que foi utilizada no experimento analógico e no experimento histórico de Geiger e Marsden, com o intuito de que os alunos percebam quais as diferenças e semelhanças há entre os experimentos.

\section{CONTEÚDO FÍSICO:}

- Interação mecânica;

- Interação elétrica;

- Parâmetro de impacto em interações de diferentes naturezas.

\section{RECURSOS:}

- Material com instruções para o professor (este material) e roteiro em papel que deverá ser preenchido pelos alunos;

- Texto 7,sobre a técnica empregada no experimento analógico e no experimento de Geiger e Marsden, com algumas questões;

- Simulação computacional "Scattering and Structure", sobre interações de diferentes tipos, a ser utilizada em conjunto com as questões 7C e 7D (Questões optativas).

\section{MOMENTOS SUGERIDOS:}

\begin{tabular}{|c|c|}
\hline \multirow{2}{*}{$\frac{\text { ro }}{\frac{2}{2}}$} & APRESENTAÇÃO DA ATIVIDADE \\
\hline & $\begin{array}{l}\text { Destaque o objetivo da atividade, que é o de analisar a técnica envolvida no } \\
\text { experimento analógico e no experimento de Geiger e Marsden. } \\
\text { Esta atividade será importante para as discussões da atividade posterior sobre os } \\
\text { aceleradores de partículas. }\end{array}$ \\
\hline \multirow[b]{2}{*}{ 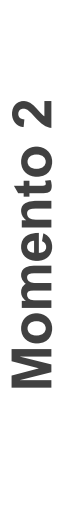 } & $\begin{array}{l}\text { COMPARAÇÃO ENTRE OS EXPERIMENTOS ANALÓGICO E } \\
\text { HISTÓRICO }\end{array}$ \\
\hline & $\begin{array}{l}\text { Os alunos deverão se dedicar à leitura do texto } 7 \text {, "Retorno ao experimento } \\
\text { analógico", e a responder as questões propostas (7A a } 7 \mathrm{~B}) \text { que tratam das semelhanças e } \\
\text { diferenças entre o experimento analógico e o experimento de Geiger e Marsden. Em seguida, } \\
\text { como uma parte optativa da atividade, os alunos poderão utilizar uma simulação que auxilia } \\
\text { nesta comparação (Scattering and Structure) respondendo as questões } 7 \mathrm{C} \text { e 7D. } \\
\text { Obs.: Como são optativos o uso da simulação e as questões } 7 \mathrm{C} \text { e } 7 \mathrm{D} \text {, estes podem ser } \\
\text { dispensados em função de ajustes de tempo necessários. }\end{array}$ \\
\hline
\end{tabular}




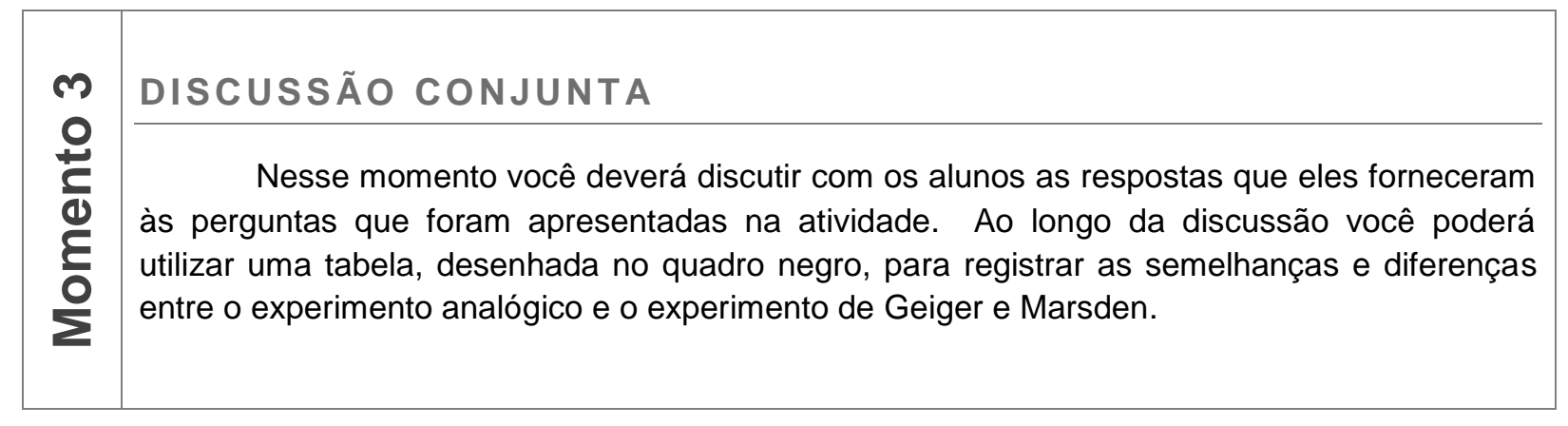




\section{TEXTO 7 - RETORNO AO EXPERIMENTO ANALÓGICO}

Os cientistas trabalham com uma grande variedade de objetos que possuem massa e dimensões muito pequenas, de maneira que parte do conhecimento científico é baseada em observações indiretas, como o padrão de dispersão.

Anteriormente, com a ajuda de bolas de gude, foi realizada uma investigação sobre a forma e o tamanho de objetos desconhecidos e não visíveis. Este experimento analógico pode nos servir para pensar alguns aspectos do experimento de Geiger e Marsden.

- Complete o seu dossiê:
7A. Que aspectos do experimento analógico foram considerados no experimento de Geiger-
Marsden?
7B. Que aspectos do experimento analógico não foram considerados no experimento de
Geiger-Marsden?

\section{- Simulação (Optativa):}

Na seguinte simulação é mostrada como um projétil interage com um alvo que pode ser escolhido. No menu Options escolha Circle Nucleus (Núcleo circular). Pressione o botão Auto-fire.

$$
\begin{gathered}
\text { Simulação "Scattering and Structure" disponível em } \\
\text { http://www.kcvs.ca/site/projects/physics files/rutherford/other nuclei.swf }
\end{gathered}
$$

\section{- Complete o seu dossiê:}

7C. (OPTATIVA) Que diferenças são observadas nas trajetórias obtidas neste caso e no núcleo do átomo de Rutherford?

7D. (OPTATIVA) Que explicação pode ser dada para estas diferenças? 


\section{ATIVIDADE V - ACELERADORES DE PARTÍCULAS}

\section{OBJETIVO:}

Esta atividade, que encerra o curso, tem por objetivo comparar a técnica utilizada no experimento analógico e no experimento de Geiger e Marsden com o que fazem os aceleradores de partículas e com a forma como eles trabalham.

\section{CONTEÚDO FÍSICO:}

- Aceleradores de partículas;

- Interação eletromagnética e interações forte e fraca (forma superficial).

\section{RECURSOS:}

- Material com instruções para o professor (este material) e roteiro em papel que deverá ser preenchido pelos alunos;

- Texto 8 sobre os aceleradores de partículas, com uma questão a ser respondida;

- Texto 9 sobre os aceleradores de partículas LHC e PELLETRON, com uma questão a ser respondida..

\section{MOMENTOS SUGERIDOS:}

\begin{tabular}{|c|c|}
\hline & APRESENTAÇÃO DA ATIVIDADE \\
\hline 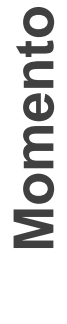 & $\begin{array}{l}\text { Na apresentação da atividade, comente que a técnica executada no experimento } \\
\text { analógico e no experimento de Geiger e Marsden está também presente nos aceleradores de } \\
\text { partículas. } \\
\text { Neste momento você poderá apresentar uma breve explicação sobre a força de } \\
\text { Lorentz, a qual é empregada nos aceleradores de partículas e permite que as partículas } \\
\text { carregadas mudem a sua direção. }\end{array}$ \\
\hline \multirow{2}{*}{ 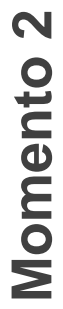 } & LEITURA DOS TEXTOS 8 E 9 \\
\hline & $\begin{array}{l}\text { Os alunos deverão se dedicar à leitura do texto } 8 \text {, Os aceleradores de partículas, e } \\
\text { do texto } 9, L H C \text { e Pelletron, e a responder as questões propostas relacionadas a cada um dos } \\
\text { textos, respectivamente a questão } 8 \mathrm{~A} \text { e a questão } 9 \mathrm{~A} \text {. }\end{array}$ \\
\hline
\end{tabular}




\section{DISCUSSÃO FINAL}

Na discussão final, aborde brevemente o que trata cada texto. Permita aos alunos, na m discussão da questão 8A, que exponham as diferenças e semelhanças que eles citaram como + existindo entre o método experimental de Geiger e Marsden e a maneira de trabalhar de um C. acelerador de partículas como o LHC. Da mesma forma, ao discutir a questão 9A, permita aos (1) alunos que também apresentem as diferenças e semelhanças entre o LHC e o Pelletron. Para 은 facilitar, desenhe no quadro negro uma tabela para cada uma das comparações.

Durante a discussão, ressalte que atualmente já se conhecem outras forças além da eletromagnética e que elas são importantes na interpretação dos dados obtidos nos aceleradores de partículas. Cite a força forte e a força fraca, que além da força elétrica, permitem explicar o comportamento de partículas subnucleares. 


\section{TEXTO 8 - OS ACELERADORES DE PARTÍCULAS*}

No início de julho de 2012 foram divulgados alguns resultados obtidos em dois experimentos (ATLAS e CMS) realizados no acelerador de partículas conhecido como LHC. Os resultados revelaram a possível descoberta de uma nova partícula sub-atômica, que provavelmente seria uma partícula prevista teoricamente e que se procurava há algumas décadas: o bóson de Higgs

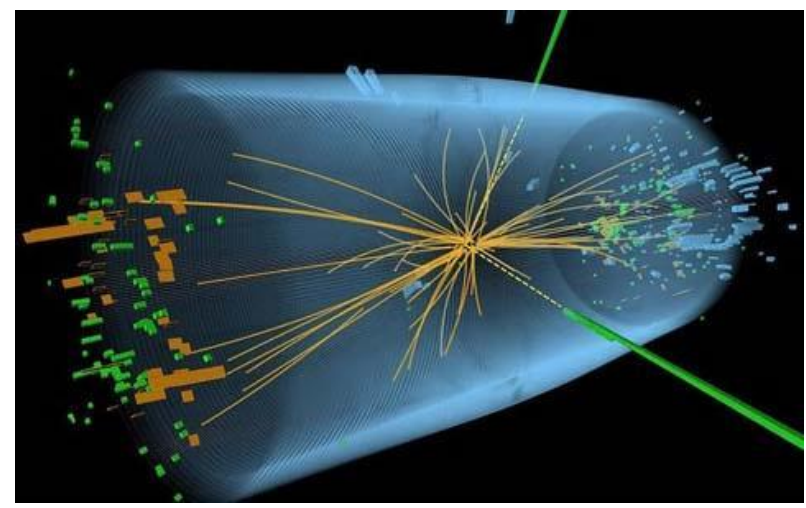

Representação da colisão de prótons medida pelo experimento CMS na busca pelo bóson de Higgs. A representação obtida é compatível com o que era esperado para a partícula bóson de Higgs (Fonte da imagem: cern.ch)

Nos experimentos ATLAS e CMS realizados no acelerador de partículas LHC, prótons são lançados para se chocarem frontalmente contra outros prótons. Dessa maneira, é possível obter partículas cada vez mais fundamentais como os quarks, ou a partícula procurada por algumas décadas, o Bóson de Higgs. As partículas são identificadas a partir das trajetórias que podem ser detectadas por vários sensores presentes no acelerador de partículas.

Mas afinal, o que são os aceleradores de partículas?

Os aceleradores de partículas são equipamentos que usam campos elétricos para permitir que partículas subatômicas ou íons (átomos carregados) possam ganhar velocidades altíssimas, e utilizam campos magnéticos para direcionar o feixe de partículas ou de íons acelerados.

As partículas subatômicas ou os íons são acelerados até se chocarem com outras partículas subatômicas, íons ou materiais macroscópicos. Com o choque, possíveis novas partículas e radiação (como os Raios $X$ ) podem ser gerados. Sensores permitem identificar a radiação e a trajetória das partículas após um choque. Os resultados experimentais são interpretados considerando a interação eletromagnética e outros tipos de interações, como a força forte e a força fraca, que ocorrem entre partículas subnucleares. A radiação gerada também é utilizada para estudar as propriedades de diferentes materiais.

\section{- Complete o seu dossiê:}

8A. Que diferenças e semelhanças há entre o método experimental de Geiger-Marsden e a maneira de trabalhar de um acelerador de partículas como o LHC?

* Atividade baseada na matéria "Físicos encontram provável 'partícula de Deus" publicada em 04/07/2012 no site da Folha de São Paulo. Disponível em http://www1.folha.uol.com.br/ciencia/1114815-fisicos-encontram-provavel-particula-de-deus.shtml 


\section{TEXTO 9 - LHC E PELLETRON}

O chamado LHC, abreviatura de Large Handrons Collider (Grande Colisor de Hádrons) é o maior acelerador de partículas existente, possivelmente o mais conhecido, e o que permite maiores velocidades das partículas aceleradas. Este acelerador de partículas se encontra a até $150 \mathrm{~m}$ de profundidade em uma região de fronteira entre a França e a Suíça. É um acelerador de partículas circular, com um túnel com cerca de $27 \mathrm{Km}$ de circunferência (equivalente à distância entre a Praça da Sé e o aeroporto de Guarulhos, ou quase duas vezes a distância entre a Praça da Sé e a Prefeitura de Osasco).

No LHC, graças a intensos campos elétricos, os prótons são acelerados a grandes velocidades para se chocarem entre si, o que permite estudar partículas conhecidas ou mesmo identificar novas partículas, como o previsto Bóson de Higgs. O LHC permite também acelerar a grandes velocidades, íons pesados (por exemplo, átomos de chumbo carregados) para colidirem entre si, sendo possível estudar outros aspectos da física de partículas (por exemplo, é esperada neste tipo de colisão a formação de uma nova fase da matéria, o "plasma quark-glúon"). Como o LHC é um acelerador circular, as partículas são redirecionadas continuamente com o uso de campos magnéticos.

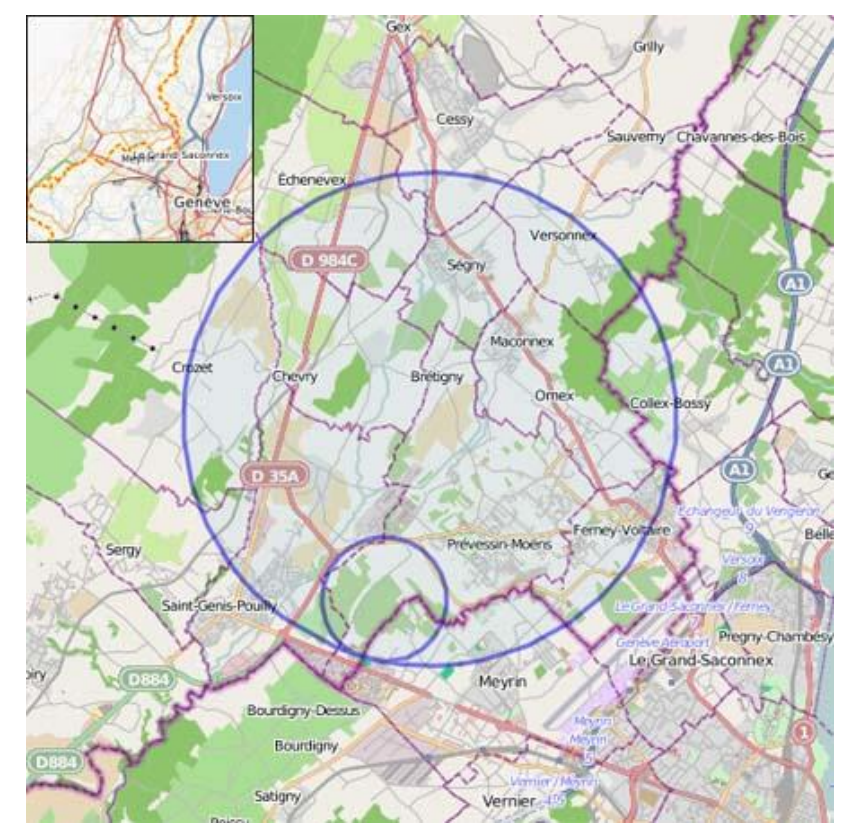

Mapa indicando o tamanho do LHC e o local em que está instalado (Fonte da imagem: commons. wikimedia.org)

No Brasil também existem aceleradores de partículas que são utilizados para as mais variadas pesquisas. Um exemplo é o acelerador de partículas Pelletron que se encontra no Instituto de Física da Universidade de São Paulo. Neste acelerador de partículas, íons leves (átomos carregados de Hidrogênio ou Hélio) são gerados e pré-acelerados em uma fonte de íons, e após são redirecionados para o acelerador, onde ganham velocidades altas devido a atuação de um campo elétrico. Após, o feixe de íons é novamente redirecionado e segue para a área experimental. A velocidade desenvolvida pelos íons no Pelletron é bem inferior à velocidade das partículas e íons acelerados no LHC, mas permitem que sejam realizadas diferentes pesquisas.

Os redirecionamentos (curvas) do feixe de íons no interior do Pelletron ocorrem devido a atuação de campos magnéticos. Na área experimental os íons colidirão com um alvo, que poderá ser um objeto macroscópico ou íons leve-pesados. O choque com o alvo gera partículas e radiações que são identificadas por sensores. A radiação gerada também é utilizada para a análise de materiais. 

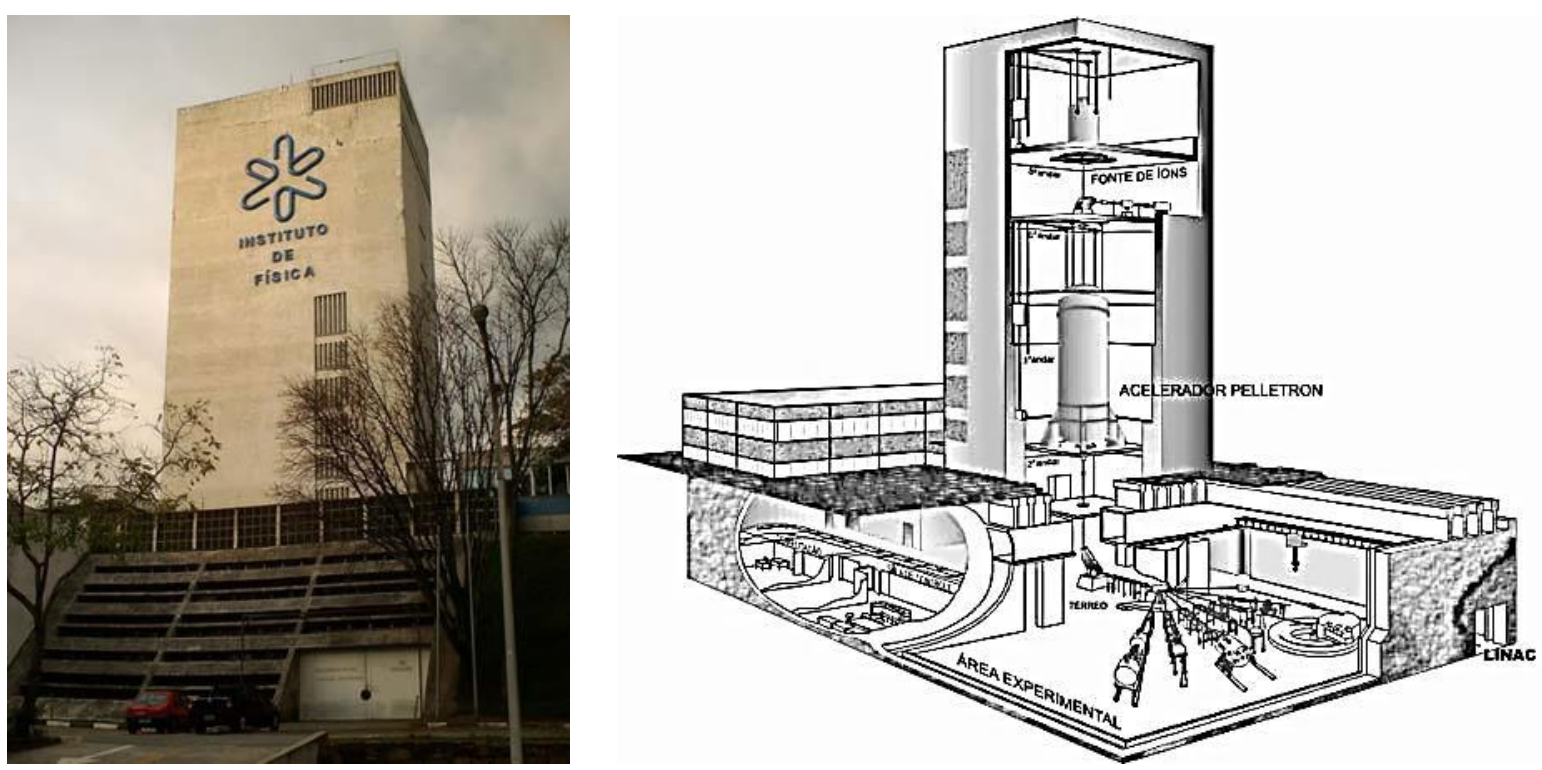

À esquerda uma foto da torre onde se encontra o acelerador de partículas Pelletron do Instituto de Física da Universidade de São Paulo, e à direita um esquema do prédio onde o acelerador está montado. (Fontes das imagens: respectivamente, commons. wikimedia.org e dfn.if.usp.br)

\section{- Complete o seu dossiê:}

9A. Que diferenças e semelhanças existem entre a maneira de trabalhar nos aceleradores de partículas LHC e Pelletron? 


\section{GABARITO DAS QUESTÕES DO CURSO}

\section{I- INTRODUÇÃO}

1. Os raios $X$ ajudam a ganhar a batalha contra as doenças do coração

1A. Em sua opinião, por que é importante "ver" o interior de um objeto? Para conhecer sua estrutura interna e sua composição.

1B. De que maneiras você acha que é possível "ver" o interior de um objeto? Quebrando o objeto, utilizando lentes, com radiação de comprimento de onda pequena (melhorando o poder de resolução), etc.

\section{Uma "fotografia especial"}

2A. $O$ que você vê na fotografia? E na radiografia?

Na fotografia a imagem de uma mão obtida pela reflexão da luz visível. Na radiografia a imagem da estrutura interna da mão, obtida por Raios $X$.

2B. Como os aparelhos de Raios $X$ obtêm imagens dos ossos da mão?

Os Raios X atravessam as partes "moles" do corpo como os tecidos não ósseos, mas não atravessam facilmente as partes "duras" do corpo, como os ossos. A radiação que atravessa chegará a uma chapa, formando o contorno dos ossos.

2C. Para você, qual é a diferença entre a radiação que se utiliza para fazer uma fotografia e a radiação utilizada para fazer uma radiografia?

Ambas são obtidas com radiações eletromagnéticas. A fotografia é obtida com o uso da luz em uma faixa do espectro da região visível, enquanto que a radiografia é obtida com o uso de radiação ionizante da faixa do espectro na região dos Raios $X$. Os Raios $X$ possuem um comprimento de onda menor e são mais energéticos do que a radiação visível, e com isso, penetram com mais facilidade na matéria, permitindo, por exemplo, que se produzam as radiografias que mostram ossos do corpo.

2D. Como se pode conseguir radiografias com mais detalhes?

Enviando uma quantidade maior de energia de Raios $X$, seja com o aumento do número de fótons, ou com o uso de fótons na faixa de Raios $X$ com energia ainda maior.

\section{II- EXPERIMENTO ANALÓGICO}

3. Outra maneira de "ver"

3A. Como você determinará o tamanho do objeto?

Lançando as bolas de gude, e pelo prolongamento das trajetórias de entrada e saída, ir determinando a área ocupada pelo objeto escondido.

3B. Como você descobrirá a forma do objeto?

Lançando as bolas de gude e estudando as trajetórias das reflexões que são produzidas pelo objeto escondido.

3C. Como você detectará se os objetos têm detalhes menores?

Lançando bolas de gude menores.

3D. Como você poderia confirmar as tuas conclusões sobre a forma e a medida do objeto sem vê-lo?

Comparando os meus resultados com os dos outros grupos que realizaram o experimento com o mesmo objeto escondido. 


\section{III- ESTRUTURA DO ÁTOMO}

\section{Modelo de Thomson}

4A. A partir da imagem do mapa de trajetórias, indique como você acha que Rutherford podia explicar:

- que as partículas alfa atravessavam o átomo;

Como o átomo de Thomson consistiria em partículas carregadas negativamente distribuídas uniformemente em uma "nuvem" carregada positivamente, as partículas alfa teriam facilidade para atravessar o átomo, pois a força elétrica resultante sobre as partículas alfa seria sempre pequena, mesmo no momento em sua trajetória em que a partícula alfa estivesse no interior do átomo.

- que quando as partículas alfa atravessavam o átomo se desviavam um pouco;

Como há uma força resultante atuante sobre as partículas alfa, esta provocará pequenos desvios na trajetória dessas partículas.

(Na imagem que representa o que Rutherford esperava, pode-se observar que os desvios são todos com ângulos positivos quando o parâmetro de impacto é maior que zero, e com ângulos negativos quando o parâmetro de impacto é menor que zero. Isso ocorre devido haver mais carga positiva entre a partícula alfa e o limite do átomo que está mais distante da partícula, fazendo com que a partícula alfa seja repelida, desviando).

- que as partículas alfa que não atravessavam o átomo também se desviavam.

Pelo mesmo motivo da resposta anterior. Como a interação é de natureza elétrica, mesmo uma partícula alfa que não atravessa o átomo de Thomson sofreria um pequeno desvio.

(Esta pergunta se refere a partículas alfa com um parâmetro de impacto maior que o raio do átomo).

5. O espalhamento de Rutherford

5A. Tendo em conta o modelo de Thomson, em que ângulos deveria ser colocado o visor para se obter a maioria de flashes possíveis?

Em ângulos próximos de zero ou igual a zero.

5B. Segundo o modelo de Thomson era esperado obter um flash com ângulos grandes? Não.

5C. O que se observa quando o visor é colocado com ângulos pequenos?

Muitas partículas alfa chegam e a imagem no visor é saturada muito rapidamente.

5D. O que se observa quando o visor é colocado com ângulos grandes?

Chegam algumas poucas partículas alfa e há uma demora considerável para que a imagem no visor fique saturada.

5E. Como você explicaria os resultados obtidos quando o visor é colocado com ângulos grandes?

Resposta do grupo. Espera-se que os alunos reconheçam que é necessária uma densidade de carga elétrica positiva maior em uma determinada região do átomo, que provocaria um grande desvio. No entanto, é possível que alguns alunos se refiram erroneamente a uma colisão mecânica entre a partícula alfa e o elétron, ou entre a partícula alfa e a "superfície" do átomo. 
5F. Naquele momento histórico já se sabia que a partícula alfa era muito maior e mais massiva que os elétrons, e que ambos eram muitos menores que o átomo. A partir desta informação, você poderia acrescentar algo à explicação que você forneceu na questão anterior?

Resposta do grupo. Como as dimensões da partícula alfa e do elétron são muito pequenas, a possibilidade de uma partícula alfa se encontrar com um elétron é praticamente nula. Além disso, mesmo que esse encontro ocorresse, como as partículas possuem cargas elétricas diferentes, elas não teriam uma repulsão, e como a massa da partícula alfa é bem superior, o encontro teria pouca influência em sua trajetória.

Logo, para explicar os ângulos grandes era necessária uma concentração de carga positiva maior que provocasse desvios grandes, e não uma distribuição uniforme entre cargas negativas e a carga positiva do átomo, como no modelo de Thomson.

5G. Pode-se concluir que o modelo atômico de Thomson está de acordo com os resultados que foram obtidos com a simulação?

Não.

5H. (Predição) Faça uma proposta de um novo modelo de átomo baseando-se naquilo que você imagina que Rutherford propôs para explicar os resultados obtidos no experimento. Faça um esquema de sua proposta.

Resposta do grupo. Os alunos poderão apresentar diferentes modelos, sendo previsível que entre as propostas apareçam aquelas que se assemelham ao átomo nuclear conforme o proposto por Rutherford.

\section{0 átomo nuclear}

6A. (Predição) $O$ que acontece quando nos fixamos somente em um núcleo atômico? Imagine que fazemos um zoom dos bombardeios das partículas alfa lançadas contra os átomos e nos fixamos no que passa na zona próxima ao núcleo de um dos átomos. Como você acha que serão as trajetórias das partículas alfa? Represente-as no esquema abaixo, para seis partículas alfa em diferentes posições inicias.

Resposta do grupo. Espera-se que as trajetórias se assemelham ao que será apresentado após na própria simulação. Porém, é possível que alguns alunos ainda indiquem uma colisão mecânica com o núcleo para as partículas alfa que possuem um parâmetro de impacto que não supere o raio do núcleo.

6B. Compare a predição que você fez na questão anterior com os resultados da simulação. Que diferenças e semelhanças existem?

\begin{tabular}{|l|l|}
\hline Diferenças & \multicolumn{1}{|c|}{ Semelhanças } \\
\hline Resposta do grupo. & Resposta do grupo. \\
& \\
& \\
\hline
\end{tabular}


6C. Que forças atuam sobre a partícula alfa quando esta se aproxima do núcleo? Força elétrica.

Obs.: A força gravitacional poderá ser citada por alguns alunos. Neste caso, destaque que pelas massas envolvidas e pela proximidade entre as partículas alfa e o núcleo, a força gravitacional será bem menor que a força elétrica e, portanto, pode ser desconsiderada.

6D. (Optativa) Selecione na simulação anterior uma energia de $15 \mathrm{MeV}$ e um parâmetro de impacto de $0,0 \mathrm{fm}$. Pressione o botão Fire. No gráfico a seguir, faça uma predição qualitativa da força que atua sobre a partícula alfa em função da distância ao núcleo.

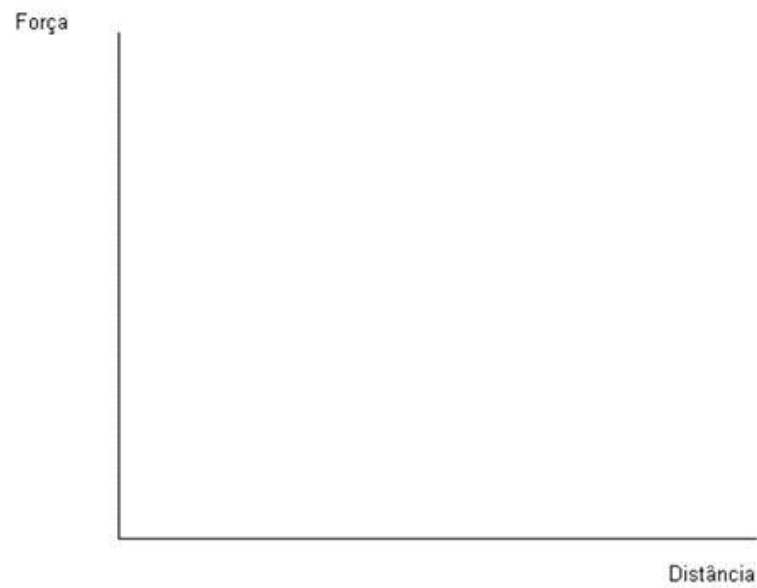

Espera-se que os alunos tracem um gráfico semelhante ao de uma função $y=n / x^{2}$, onde $n$ é um número. Tal gráfico é característico da força elétrica em função da distância. Um exemplo é apresentado abaixo:

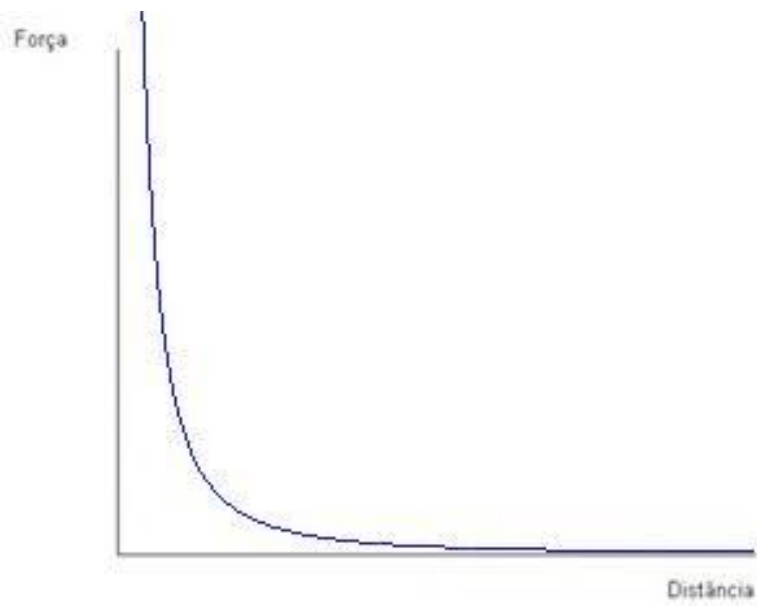

6E. (Optativa) Compare a sua predição com o gráfico montado pela simulação. Para isso, selecione no menu Options o item Show Graph. Que diferenças existem?

Resposta do grupo.

6F. Selecione um valor de $\underline{5.0 \mathrm{fm}}$ para o parâmetro de impacto e clique no botão Fire. Você deverá obter algo semelhante à figura abaixo. Na figura abaixo, desenhe o vetor força elétrica atuante sobre a partícula alfa para três posições específicas dessa partícula: uma próxima ao início da trajetória (mais à esquerda), uma próxima ao núcleo e outra após o desvio. 
Espera-se que os alunos tracem o vetor força elétrica de acordo com o esperado para uma interação elétrica entre cargas de mesmo sinal (partículas alfa e núcleo do átomo de Rutherford), como apresentado a seguir:

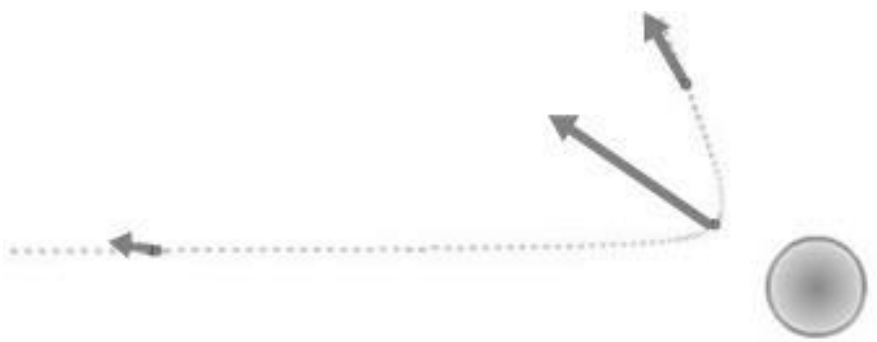

É provável que alguns alunos desenhem erroneamente os vetores força com o sentido e intensidade semelhante ao esperado para o vetor velocidade, onde o vetor possui o mesmo sentido do deslocamento e o tamanho do vetor seria maior em regiões mais distantes do núcleo.

6G. Como você mudaria a trajetória e o esquema de forças anterior se a carga do núcleo fosse menor? Após responder, mantendo um valor de $\underline{5.0 \mathrm{fm}}$ para o parâmetro de impacto, comprove sua resposta selecionando na simulação o elemento alumínio, o qual possui um núcleo com uma carga elétrica menor.

Como o núcleo do alumínio possui uma carga elétrica menor, a força de repulsão terá menor intensidade, e assim, a partícula alfa se aproximará mais do núcleo em sua trajetória. Já em relação aos vetores força elétrica, para a mesma distância dos pontos anteriores, o vetor deverá ser menor.

6H. Sem utilizar a simulação, o que você acha que ocorreria se mudássemos a energia das partículas alfa incidentes?

Com maior energia, as partículas alfa se deslocariam mais rápido, e assim, haveria menos tempo para que a força elétrica atuasse sobre as partículas alfa. Como consequência, o desvio seria menor.

Com menor energia, as partículas alfa se deslocariam mais devagar, e assim, haveria mais tempo para que a força elétrica atuasse sobre as partículas alfa. Como consequência, o desvio seria maior.

\section{IV- A TÉCNICA}

\section{Retorno ao experimento analógico}

7A. Que aspectos do experimento analógico foram considerados no experimento de GeigerMarsden?

O lançamento de projéteis para se obter informações de algo desconhecido.

7B. Que aspectos do experimento analógico não foram considerados no experimento de Geiger- Marsden?

O tamanho dos projéteis relacionado à identificação detalhes, a identificação da forma do objeto a partir das trajetórias.

(Pelas trajetórias foi possível inferir a estrutura do átomo no experimento de Geiger-Marsden, não a forma).

7C. (Optativa) Que diferenças são observadas nas trajetórias obtidas neste caso e no núcleo do átomo de Rutherford?

Neste caso (com a opção Circle Nucleus) o objeto circular é tocado, enquanto que para o núcleo atômico de Rutherford, este não é tocado.

7D. (Optativa) Que explicação pode ser dada para estas diferenças?

O objeto circular (Circle Nucleus) não está carregado, enquanto que o núcleo do átomo de Rutherford está carregado positivamente, assim como as partículas alfa que são lançadas contra o átomo. A força elétrica de repulsão impede que as partículas alfa toquem o núcleo representado na simulação. 


\section{V- ACELERADORES DE PARTÍCULAS}

\section{Os aceleradores de partículas}

8A. Que diferenças e semelhanças há entre o método experimental de Geiger-Marsden e a maneira de trabalhar de um acelerador de partículas como o LHC?

\begin{tabular}{|c|c|}
\hline Diferenças & Semelhanças \\
\hline $\begin{array}{l}\text { - As partículas carregadas lançadas no } \\
\text { experimento de Geiger-Marsden são } \\
\text { somente partículas alfa. Os aceleradores } \\
\text { de partículas, dependendo do tipo, lançam } \\
\text { desde partículas subatômicas até átomos } \\
\text { carregados (íons). } \\
\text { - alvo no experimento de Geiger- } \\
\text { Marsden é um objeto macroscópico, } \\
\text { enquanto que nos aceleradores de } \\
\text { partículas, dependendo do que se } \\
\text { pretende estudar, são desde objetos } \\
\text { macroscópicos até partículas } \\
\text { subatômicas; } \\
\text { - Nos aceleradores de partículas outros } \\
\text { tipos de interação (força forte e força } \\
\text { fraca) são também relevantes para } \\
\text { interpretar os resultados; } \\
\text { - Os aceleradores de partículas utilizam } \\
\text { campos magnéticos para direcionar os } \\
\text { projéteis ao longo da trajetória, enquanto } \\
\text { que no experimento de Geiger-Marsden, } \\
\text { eram utilizados filtros no início da } \\
\text { trajetória (materiais que impediam que a } \\
\text { radiação se dissipasse, a não ser por um } \\
\text { "furo"). }\end{array}$ & $\begin{array}{l}\text { - Lançamento de partículas carregadas } \\
\text { permitindo conhecer o interior da matéria; } \\
\text { - Se conhece as propriedades do objeto } \\
\text { que é lançado; } \\
\text { - A interação elétrica é relevante para } \\
\text { interpretar os resultados; } \\
\text { - A velocidade do projétil é relevante para } \\
\text { interpretar os resultados; } \\
\text { - Tanto o experimento de Geiger-Marsden } \\
\text { como os aceleradores de partículas } \\
\text { utilizam campos elétricos para acelerar os } \\
\text { projéteis. }\end{array}$ \\
\hline
\end{tabular}

\section{LHC e Pelletron}

9A. Que diferenças e semelhanças existem entre a maneira de trabalhar nos aceleradores de partículas LHC e Pelletron?

\begin{tabular}{|c|c|}
\hline Diferenças & Semelhanças \\
\hline $\begin{array}{l}\text { - Enquanto o LHC é circular, o Pelletron é } \\
\text { composto por curvas e, também, por } \\
\text { retas; } \\
\text { - No LHC há a colisão entre prótons ou } \\
\text { entre íons pesados. No Pelletron há a } \\
\text { colisão entre íons leves e materiais } \\
\text { macroscópicos, ou entre íons leves e íons } \\
\text { leves-pesados; } \\
\text { - A velocidade das partículas aceleradas } \\
\text { no LHC é bem superior a dos íons } \\
\text { acelerados no Pelletron. }\end{array}$ & $\begin{array}{l}\text { - Ambos os aceleradores de partículas } \\
\text { utilizam campos elétricos para acelerar as } \\
\text { partículas; } \\
\text { - Ambos os aceleradores de partículas } \\
\text { utilizam campos magnéticos para } \\
\text { redirecionar o feixe de partículas; } \\
\text { - A colisão que ocorre nos dois } \\
\text { aceleradores de partículas gera radiação e } \\
\text { outras partículas, que podem ser } \\
\text { detectadas por sensores. }\end{array}$ \\
\hline
\end{tabular}




\section{APÊNDICE B - MATERIAL DO ALUNO (DOSSIÊ)}




\section{De Thomson aos Aceleradores de Partículas}




\section{I- INTRODUÇÃO}

1. Os raios $X$ ajudam a ganhar a batalha contra as doenças do coração

1A. Em sua opinião, por que é importante "ver" o interior de um objeto?

1B. De que maneiras você acha que é possível "ver" o interior de um objeto?

2. Uma "fotografia especial"

2A. O que você vê na fotografia? E na radiografia?

2B. Como os aparelhos de Raios X obtêm imagens dos ossos da mão?

2C. Para você, qual é a diferença entre a radiação que se utiliza para fazer uma fotografia e a radiação utilizada para fazer uma radiografia?

2D. Como se pode conseguir radiografias com mais detalhes?

\section{II- EXPERIMENTO ANALÓGICO}

3. Outra maneira de "ver"

3A. Como você determinará o tamanho do objeto?

3B. Como você descobrirá a forma do objeto?

3C. Como você detectará se os objetos têm detalhes menores?

3D. Como você poderia confirmar as tuas conclusões sobre a forma e a medida do objeto sem vê-lo? 


\section{III- ESTRUTURA DO ÁTOMO}

4. Modelo de Thomson

4A. A partir da imagem do mapa de trajetórias, indique como você acha que Rutherford podia explicar:

- que as partículas alfa atravessavam o átomo;

- que quando as partículas alfa atravessavam o átomo se desviavam um pouco;

- que as partículas que não atravessavam o átomo também se desviavam.

5. 0 espalhamento de Rutherford

5A. Tendo em conta o modelo de Thomson, em que ângulos deveria ser colocado o visor para se obter a maioria de flashes possíveis?

5B. Segundo o modelo de Thomson era esperado obter um flash com ângulos grandes?

5C. O que se observa quando o visor é colocado com ângulos pequenos?

5D. O que se observa quando o visor é colocado com ângulos grandes?

5E. Como você explicaria os resultados obtidos quando o visor é colocado com ângulos grandes?

5F. Naquele momento histórico já se sabia que a partícula alfa era muito maior e mais massiva que os elétrons, e que ambos eram muitos menores que 0 átomo. A partir desta informação, você poderia acrescentar algo à explicação que você forneceu na questão anterior?

5G. Pode-se concluir que o modelo atômico de Thomson está de acordo com os resultados que foram obtidos com a simulação? 
5H. (Predição) Faça uma proposta de um novo modelo de átomo baseando-se naquilo que você imagina que Rutherford propôs para explicar os resultados obtidos no experimento. Faça um esquema de sua proposta.

6. 0 átomo nuclear

6A. (Predição) $O$ que acontece quando nos fixamos somente em um núcleo atômico? Imagine que fazemos um zoom dos bombardeios das partículas alfa lançadas contra os átomos e nos fixamos no que passa na zona próxima ao núcleo de um dos átomos. Como você acha que serão as trajetórias das partículas alfa? Represente-as no esquema abaixo, para seis partículas alfa em diferentes posições inicias.

6B. Compare a predição que você fez na questão anterior com os resultados da simulação. Que diferenças e semelhanças existem?

\begin{tabular}{|c|c|}
\hline Diferenças & Semelhanças \\
\hline & \\
& \\
& \\
& \\
\hline
\end{tabular}

6C. Que forças atuam sobre a partícula alfa quando esta se aproxima do núcleo? 
6D. (Optativa) Selecione na simulação anterior uma energia de $15 \mathrm{MeV}$ e um parâmetro de

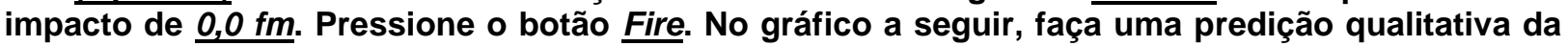
força que atua sobre a partícula alfa em função da distância ao núcleo.

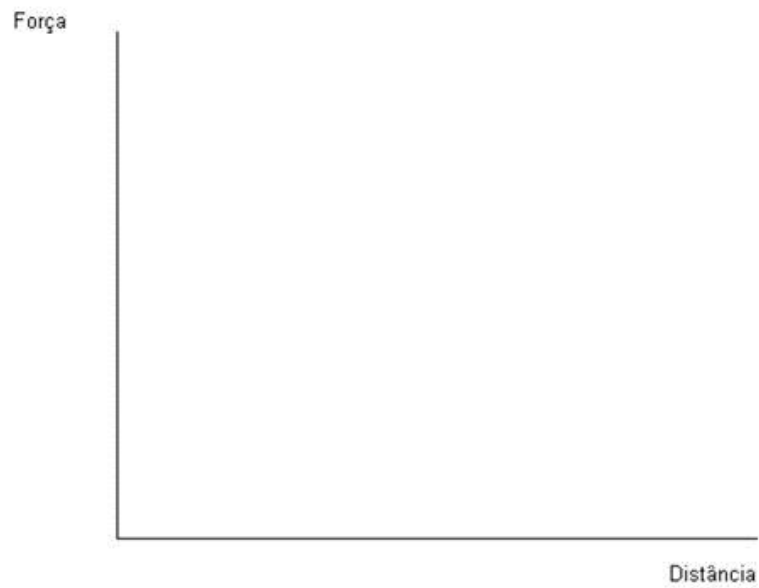

6E. (Optativa) Compare a sua predição com o gráfico montado pela simulação. Para isso, selecione no menu Options o item Show Graph. Que diferenças existem?

6F. Selecione um valor de $\underline{5.0 \mathrm{fm}}$ para o parâmetro de impacto e clique no botão Fire. Você deverá obter algo semelhante à figura abaixo. Na figura abaixo, desenhe o vetor força elétrica atuante sobre a partícula alfa para três posições específicas dessa partícula: uma próxima ao início da trajetória (mais à esquerda), uma próxima ao núcleo e outra após o desvio.

6G. Como você mudaria a trajetória e o esquema de forças anterior se a carga do núcleo fosse menor? Após responder, mantendo um valor de $\underline{5.0 \mathrm{fm}}$ para o parâmetro de impacto, comprove sua resposta selecionando na simulação o elemento alumínio, o qual possui um núcleo com uma carga elétrica menor.

6H. Sem utilizar a simulação, o que você acha que ocorreria se mudássemos a energia das partículas alfa incidentes? 


\section{IV- A TÉCNICA}

\section{Retorno ao experimento analógico}

7A. Que aspectos do experimento analógico foram considerados no experimento de GeigerMarsden?

7B. Que aspectos do experimento analógico não foram considerados no experimento de GeigerMarsden?

7C. (Optativa) Que diferenças são observadas nas trajetórias obtidas neste caso e no núcleo do átomo de Rutherford?

7D. (Optativa) Que explicação pode ser dada para estas diferenças?

\section{V- ACELERADORES DE PARTÍCULAS}

\section{Os aceleradores de partículas}

8A. Que diferenças e semelhanças há entre o método experimental de Geiger-Marsden e a maneira de trabalhar de um acelerador de partículas como o LHC?

\begin{tabular}{|c|c|}
\hline Diferenças & Semelhanças \\
\hline & \\
& \\
& \\
\hline
\end{tabular}

\section{LHC e Pelletron}

9A. Que diferenças e semelhanças existem entre a maneira de trabalhar nos aceleradores de partículas LHC e Pelletron?

\begin{tabular}{|c|c|}
\hline Diferenças & \\
\hline & \\
& \\
& \\
& \\
\hline
\end{tabular}

